\title{
WestVirginiaUniversity
}

THE RESEARCH REPOSITORY @ WVU

Graduate Theses, Dissertations, and Problem Reports

2003

\section{Characterization of in-use emissions from on-highway heavy-duty diesel engines}

Mohan Krishnamurthy

West Virginia University

Follow this and additional works at: https://researchrepository.wvu.edu/etd

\section{Recommended Citation}

Krishnamurthy, Mohan, "Characterization of in-use emissions from on-highway heavy-duty diesel engines" (2003). Graduate Theses, Dissertations, and Problem Reports. 1384.

https://researchrepository.wvu.edu/etd/1384

This Thesis is protected by copyright and/or related rights. It has been brought to you by the The Research Repository @ WVU with permission from the rights-holder(s). You are free to use this Thesis in any way that is permitted by the copyright and related rights legislation that applies to your use. For other uses you must obtain permission from the rights-holder(s) directly, unless additional rights are indicated by a Creative Commons license in the record and/ or on the work itself. This Thesis has been accepted for inclusion in WVU Graduate Theses, Dissertations, and Problem Reports collection by an authorized administrator of The Research Repository @ WVU. For more information, please contact researchrepository@mail.wvu.edu. 
Characterization of In-Use Emissions from On-Highway Heavy-Duty Diesel Engines

\author{
Mohan Krishnamurthy
}

Thesis submitted to

The College of Engineering and Mineral Resources

at West Virginia University in partial fulfillment of the requirements

for the degree of

Master of Science

in

Mechanical Engineering

Approved by

Mridul Gautam, Ph.D., Chair

Nigel N. Clark, Ph.D.

Gregory J. Thompson, Ph.D.

Department of Mechanical and Aerospace Engineering

Morgantown, West Virginia

2003

Keywords: In-use Emissions, Diesel Engines, Modal Analysis, Uncertainty, Consent Decrees 


\section{ABSTRACT \\ Characterization of In-Use Emissions from On-Highway Heavy-Duty Diesel Engines Mohan Krishnamurthy}

Class- 8 trucks with GVWR of 80,000 lbs were tested on different driving routes and inuse brake-specific emissions of $\mathrm{NO}_{\mathrm{x}}$ and $\mathrm{CO}_{2}$ data were collected using the West Virginia University's Mobile Emissions Measurement System (MEMS). An uncertainty analysis was performed on the MEMS and it was determined the maximum possible error in the measurement of brake-specific emissions of $\mathrm{NO}_{\mathrm{x}}$ was $8 \%$ and $\mathrm{CO}_{2}$ was $6 \%$.

A modal analysis indicated that the cruise mode comprised $70 \%$ of the time that the vehicle spent in the Not-to-Exceed (NTE) zone while the acceleration and deceleration modes about $20 \%$ and $10 \%$ respectively.

In order to reduce the uncertainties in emissions measurement, it is proposed that fuel specific $\mathrm{NO}_{\mathrm{x}}$, a ratio $\mathrm{NO}_{\mathrm{x}} / \mathrm{CO}_{2}$ be used for emissions compliance purposes. The values of the proposed ratio were found to vary from 1.17 to 1.83 depending upon engine model, model year, manufacturer and the driving route. 


\section{ACKNOWLEDGEMENTS}

The completion of my master's career would not have been possible without the assistance and encouragement of many people. So as I write this very important and difficult section, I reflect back on the last two years and on the individuals who have left an impact on me.

Dr. Mridul Gautam, thank you. To describe the amount of help you have given to me would be a thesis in itself! Your words of encouragement and continued guidance have taken me to a different level. Working with you has been an excellent learning experience. You have been a great advisor and an exceptional friend.

Three very important people who have left a lasting impression on me are Greg Thompson, Dan Carder, and Wesley Riddle. Your hard work and dedication won over my admiration and respect. Greg's drive for perfection thrills me, Dan's insight amazes me, and Wes's skepticism riddles me. I thank you for giving me the invaluable. Greg and Dan - I would also like to thank you for taking me out to hunt: I am now a "Hunter."

Dr. Nigel Clark, thank you for taking time out of your hectic schedule to be on my committee. I enjoyed every bit of the time I worked with you during this project. Thank you.

A ship can never sail without its crew, and I thank everyone at EERC for the support you have unconditionally provided to me. Tom, thank you for familiarizing me with electrical circuits, for your constant positive disposition and irreplaceable sense of humor. Richard: without you I would've been a child wandering around a chocolate factory. The countless evenings you spent explaining systems helped me get focused. Richard, just for the record, I am definitely going to hold the World Cup one day! My heartfelt thanks goes to Andy Pertl, for helping me with programming. Aaron, Ares and Adam: thank you for helping me around the lab. I am grateful to all of you at EERC: you were amazing to work with!

I need to thank my contemporaries: Sairam, Sam, Guru, Hemant, and Vinay: thank you for all the help and the fun you made available. Sam, thank you for the schematics that enabled me to complete my thesis on time. Also my thanks goes out to Axel, Ron and John, for helping me in testing and providing me with data.

Last but not least, I thank my Mom and Dad, my brother Anil, my aunt, my uncle and my friends for their patience, prayers, and for all the motivation that kept me going each day. I would have never got this far without you all. I owe everything that I am to you. 
TABLE OF CONTENTS

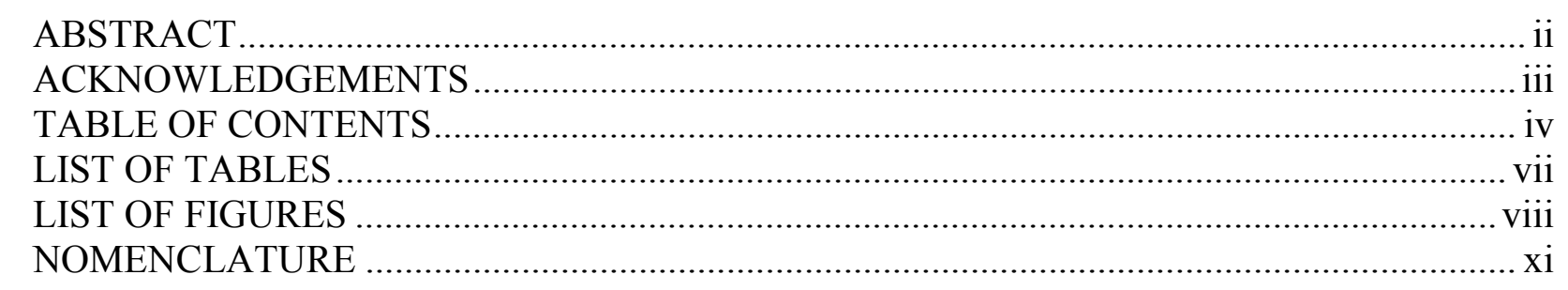

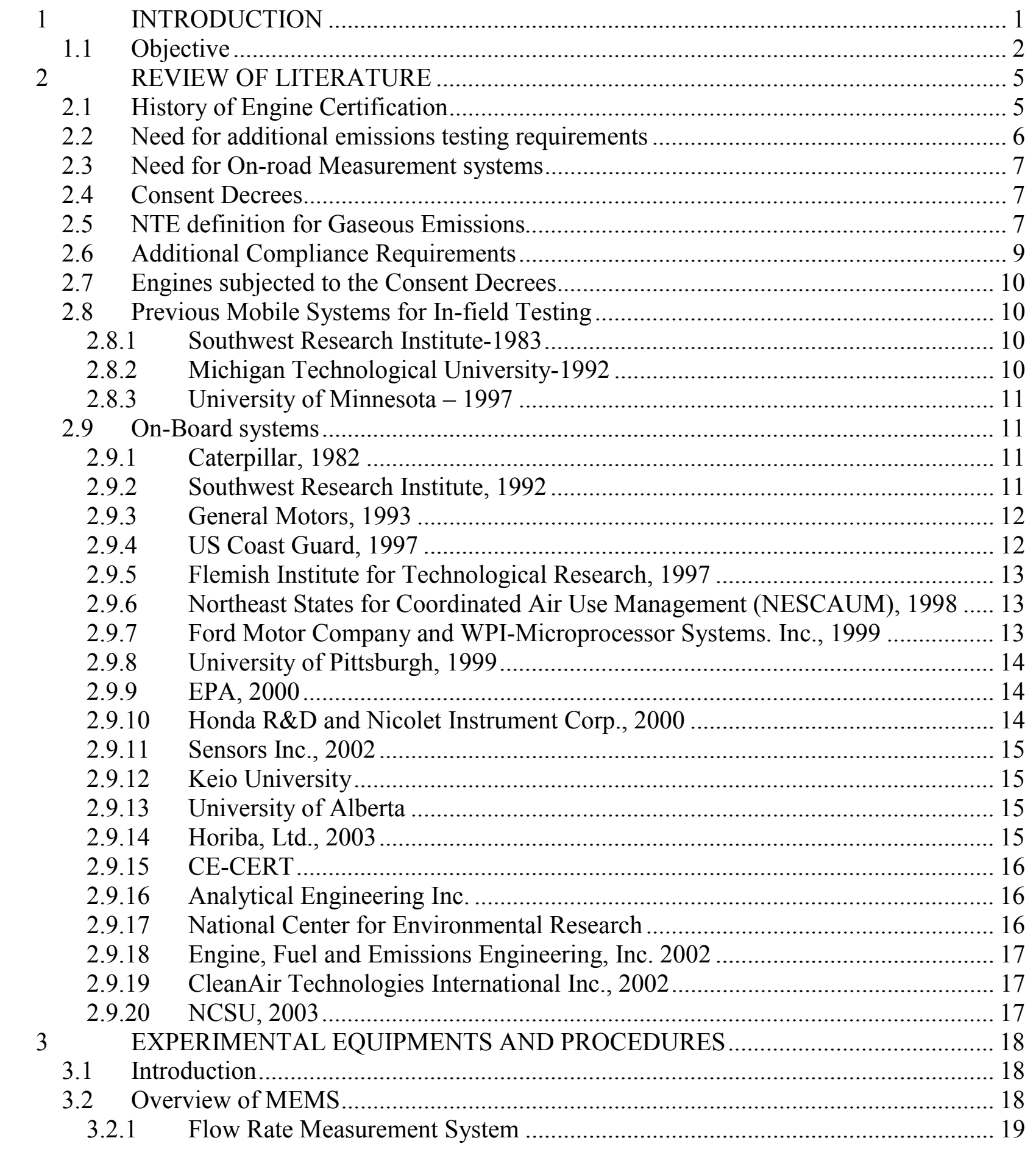


3.2.2 Gaseous Sampling and Sample Conditioning System ................................. 19

3.2.3 Engine Speed and Torque Measurement ................................................. 21

3.2.4 Data Acquisition, Reduction and Archival Subsystem ................................ 21

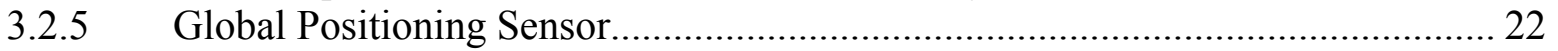

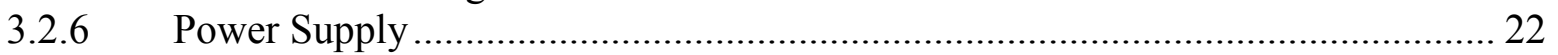

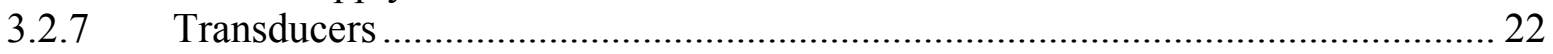

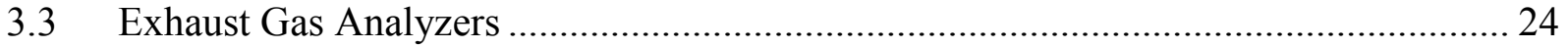

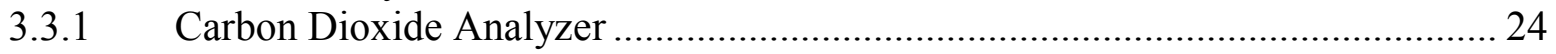

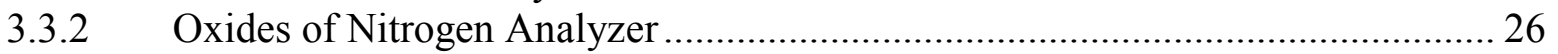

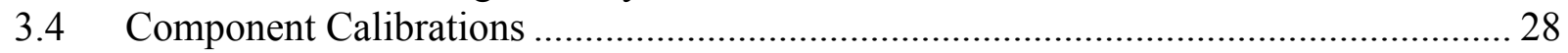

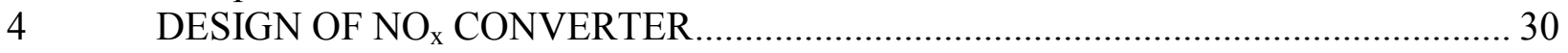

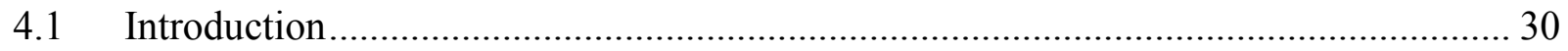

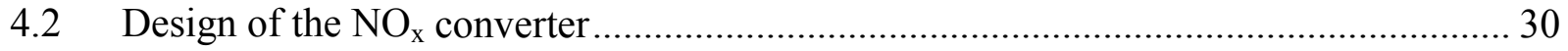

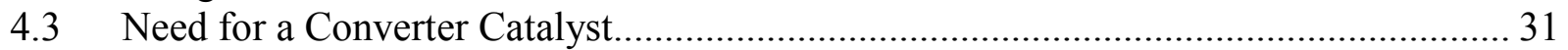

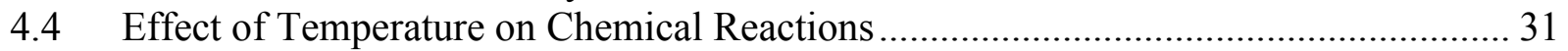

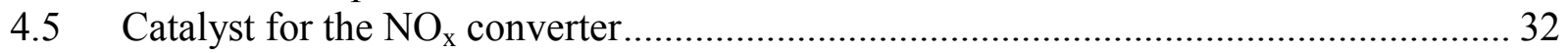

4.6 Effect of the Sampling System Configuration on the Conversion efficiency of the $\mathrm{NO}_{\mathrm{x}}$

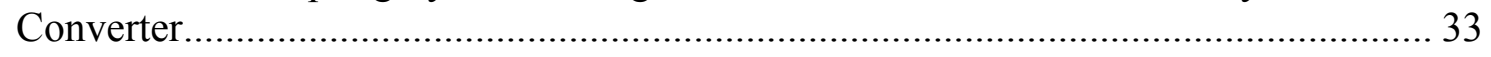

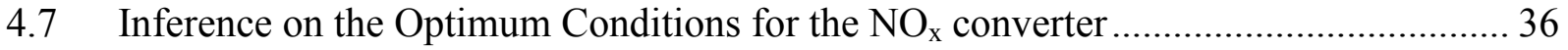

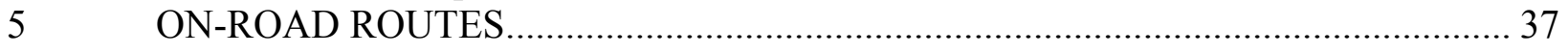

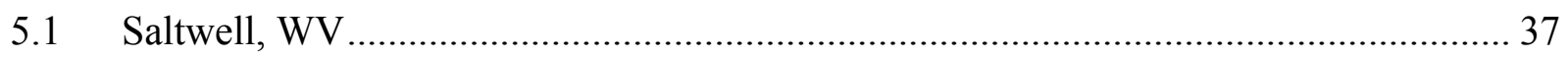

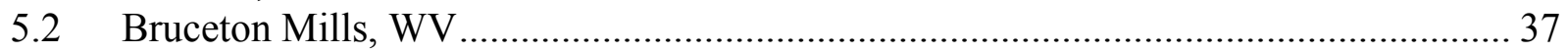

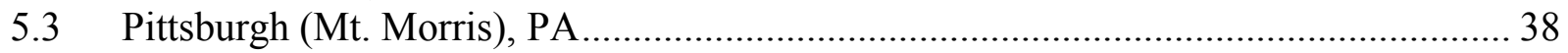

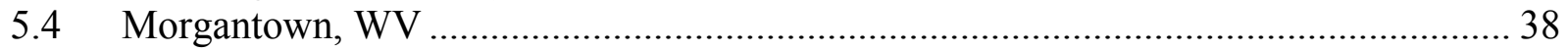

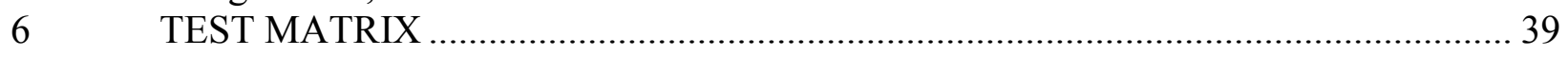

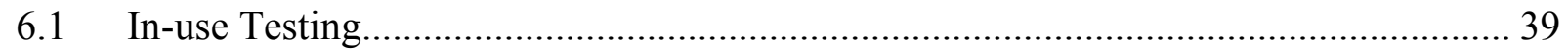

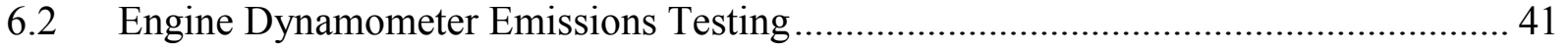

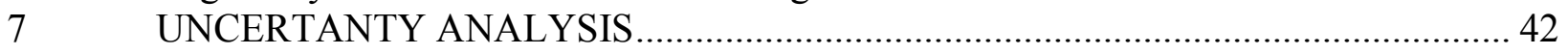

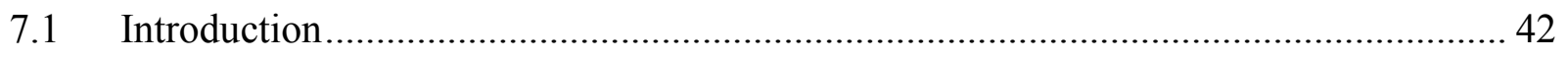

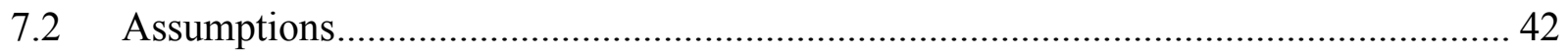

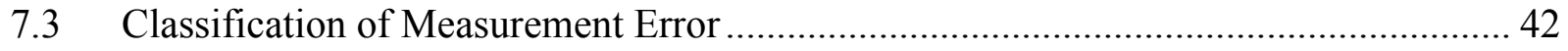

7.3.1 Random Error............................................................................................ 42

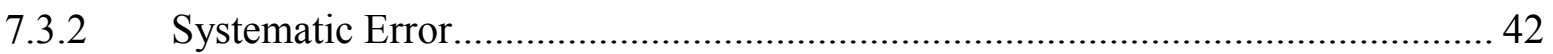

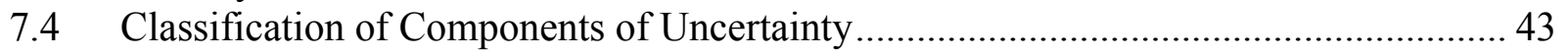

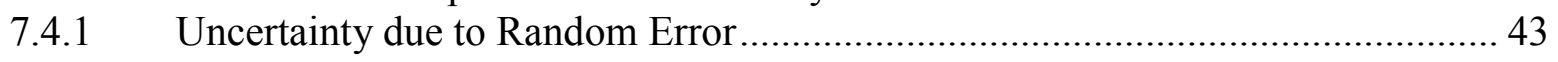

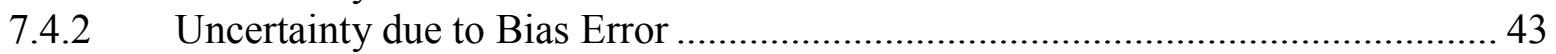

$7.5 \quad$ Classification of Type of Uncertainty evaluation ........................................ 43

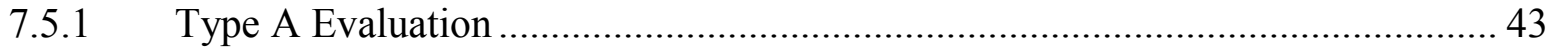

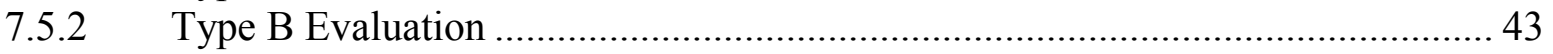

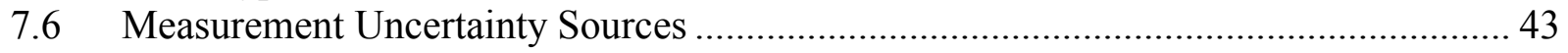

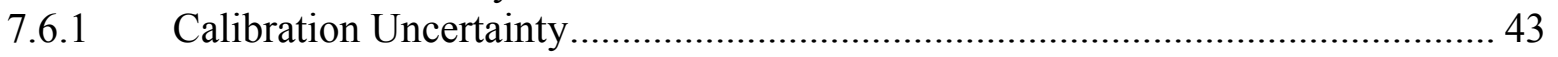

Data Acquisition Uncertainty .......................................................... 44

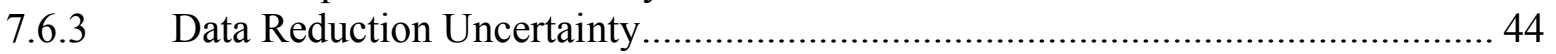

7.6.4 Uncertainty due to Methods .............................................................. 44

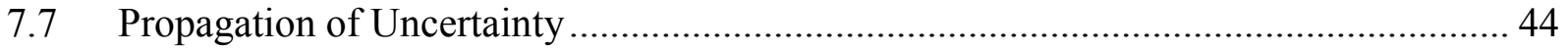

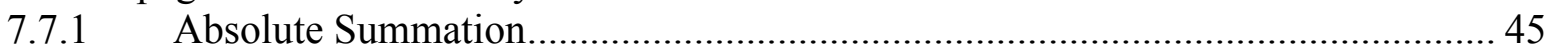

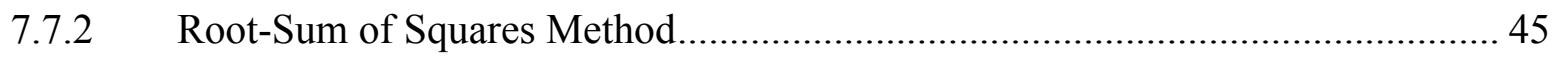

$7.8 \quad$ Uncertainty in Brake Specific Emissions ..................................................... 46 


\begin{tabular}{|c|c|}
\hline 7.9 & Calculation of Uncertainty of Concentration Values .......................... \\
\hline 7.9 .1 & 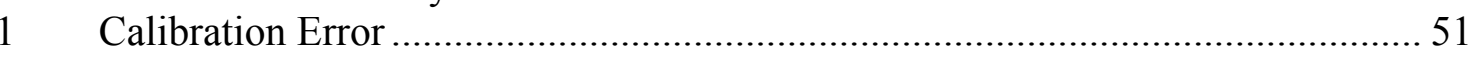 \\
\hline 7.9 .2 & Data Reduction Error ... \\
\hline 7.9 .3 & Analyzer Error ............... \\
\hline$\overline{7.9 .4}$ & 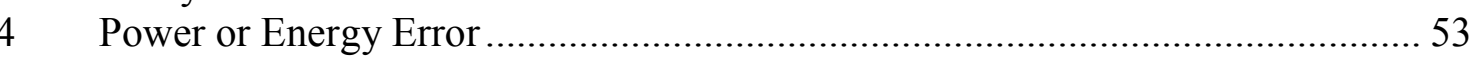 \\
\hline 7.10 & Results and Discussions on Uncertainty in Brake-Specific Emissions …................ 53 \\
\hline 7.11 & 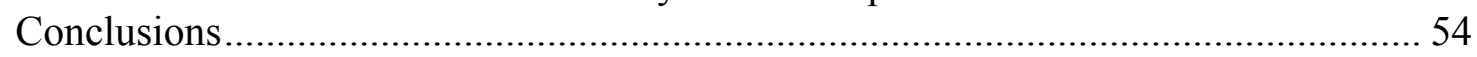 \\
\hline & RESULTS AND DISCUSSIONS ................................. \\
\hline $8.1 \quad 1$ & Representation of Time Traces and Emissions Episodes \\
\hline 8.1 .1 & $1 \quad$ SAB2BM \\
\hline 8.1 .2 & 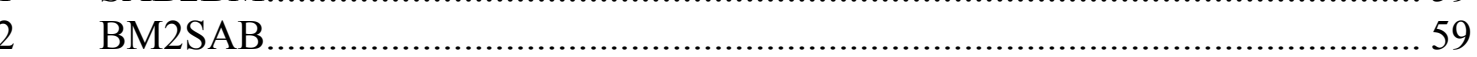 \\
\hline 8.1 .3 & 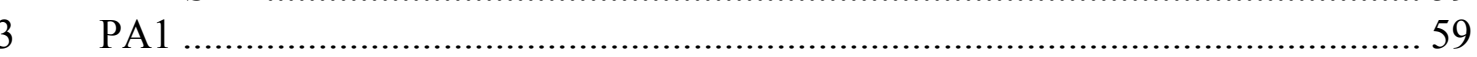 \\
\hline 8.1 .4 & PA2 ............. \\
\hline 8.1 .5 & PA3 …................ \\
\hline 8.1 .6 & 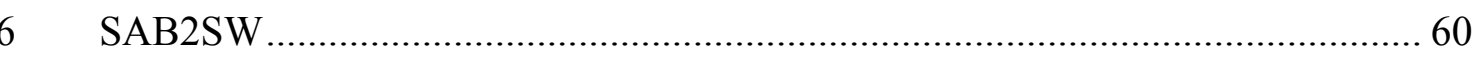 \\
\hline$\overline{8.1 .7}$ & SW2SAB ................................... \\
\hline 8.21 & Modal Emissions Analysis Results ........................ \\
\hline 8.3 & Representation of Engine Operation on Lug curve............................. \\
\hline 8.4 & Comparison of Time Spent in the NTE Region for Different Routes ..................... 83 \\
\hline 8.5 & 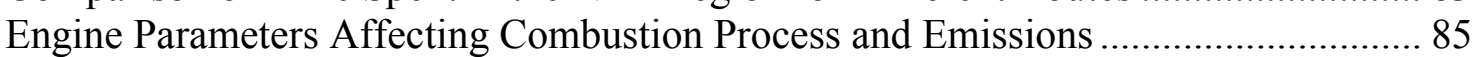 \\
\hline 8.5 .1 & $1 \quad$ Effect of Engine Load on Brake-Specific Emissions ................................. 86 \\
\hline 8.5 .2 & Effect of Engine Speed on Brake-Specific Emissions .................................. 88 \\
\hline 8.5 .3 & $3 \quad$ Effect of Engine Power on Brake-Specific Emissions …............................... 89 \\
\hline $8.6 \quad$ & Quantification of NTE Emissions based on $\mathrm{NO}_{\mathrm{x}} / \mathrm{CO}_{2}$ Ratios ......... \\
\hline & CONCLUSIONS AND RECOMMENDATIONS ................. \\
\hline 9.1 & 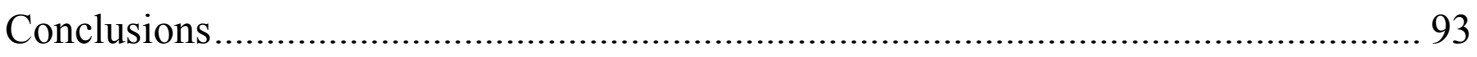 \\
\hline 9.2 & 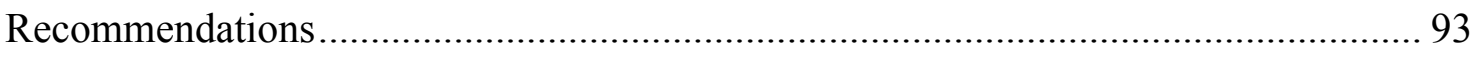 \\
\hline & 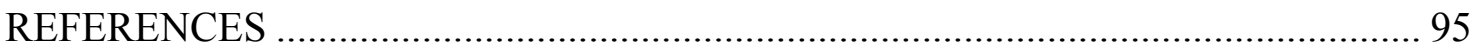 \\
\hline PPEND & IX A Three Dimensional Representation of Variation of NTE bsNO ${ }_{x}$ with Engine \\
\hline & Parameters (Class 8 Tractor, 435hp, 1550 ft-lb @,1700 RPM, MY1996). \\
\hline
\end{tabular}

Manufacturers 


\section{LIST OF TABLES}

\begin{tabular}{|c|c|}
\hline Table 2-1 & Emissions standards for Heavy-Duty diesel engine \\
\hline Table 2-2 & HDDE emissions standard in compliance with the Consent Decrees........ \\
\hline Table 2-3 & HDDE emissions standards for Post 2001 engines ................................... \\
\hline Table 3-1 & Absolute pressure transducer specifications. ..................... \\
\hline Table 3-2 & 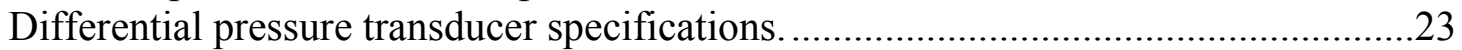 \\
\hline Table 3-3 & 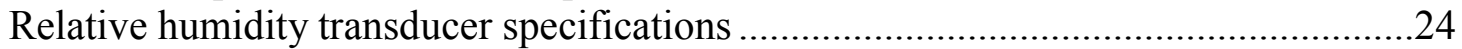 \\
\hline Table 3-4 & Analyzers used .................................................. \\
\hline Table 3-5 & Specifications of MEXA $120 \mathrm{NO}_{\mathrm{x}}$ analyzer ............. \\
\hline Table 3-6 & 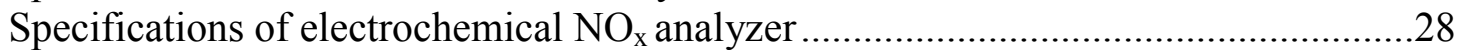 \\
\hline Table 4-1 & Catalysts used for the converter testing .............. \\
\hline Table 4-2 & Sampling conditions for the $\mathrm{NO}_{\mathrm{x}}$ converter. \\
\hline Table 6-1 & Summary of test routes performed for each vehicle with Caterpillar engine .............. \\
\hline Table 6-2 & Summary of test routes performed for each vehicle with International Engine ......... \\
\hline Table 6-3 & Summary of test routes performed for each vehicle with Cummins engine......... \\
\hline Table 6-4 & Summary of test routes performed for each vehicle with DDC engine ......... \\
\hline Table 6-5 & Summary of test routes performed for each vehicle with Mack engine .... \\
\hline Table 6-6 & Summary of test routes performed for each vehicle with Volvo engine .................... \\
\hline Table 6-7 & Summary of engine dynamometer testing .............................................................4 \\
\hline \multirow[t]{2}{*}{ Table 7-1 } & \begin{tabular}{|l|l} 
List of instruments used for differential \& absolute pressure and temperature & \\
\end{tabular} \\
\hline & 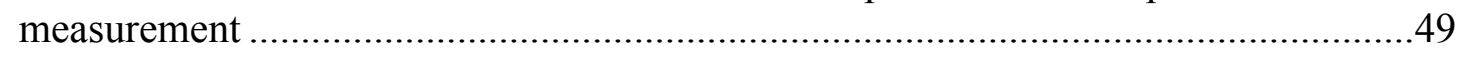 \\
\hline Table 7-2 & Errors in absolute pressure measurement ............................ \\
\hline Table 7-3 & Errors in differential pressure measurement ....................... \\
\hline Table 7-4 & 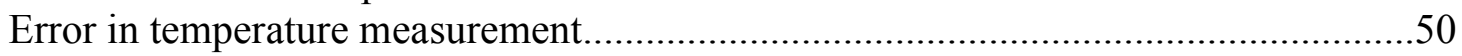 \\
\hline Table 7-5 & Specifications of instruments used in gaseous concentration measurement... \\
\hline Table 7-6 & 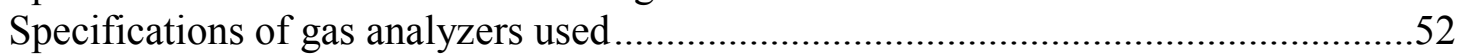 \\
\hline Table 8-1 & Summary of load factor for different routes on a MY1997 engine \\
\hline Table 8-2 & Baseline $\mathrm{NO}_{\mathrm{x}} / \mathrm{CO}_{2}$ calculations for a $\mathrm{MY} 1997$ engine ......... \\
\hline Table B-1 & Baseline $\mathrm{NO}_{\mathrm{x}} / \mathrm{CO}_{2}$ calculations for a MY 1996 engine.. \\
\hline Table B-2 & Baseline $\mathrm{NO}_{\mathrm{x}} / \mathrm{CO}_{2}$ calculations for a MY 1998 engine .... \\
\hline Table B-3 & Baseline $\mathrm{NO}_{\mathrm{x}} / \mathrm{CO}_{2}$ calculations for a MY 1998 engine ....... \\
\hline
\end{tabular}




\section{LIST OF FIGURES}

Figure 2.1 Representation of speed and torque set points for a FTP cycle. [7] ..........................6

Figure 2.2 Graphical definition of NTE zone for gaseous emissions. [10].............................8

Figure 3.1 Data acquisition and sampling conditioning and analysis systems of MEMS...........18

Figure 3.2 $\quad$ Representation of the exhaust flow measurement system fitted to the test vehicle......19

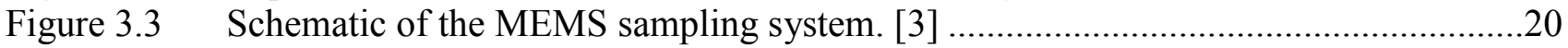

Figure 3.4 Schematic of the operating principle of the BE-140AD analyzer. ..........................25

Figure 3.5 Schematic of the operating principle of $\mathrm{NO}_{\mathrm{x}}$ sensor......................................27

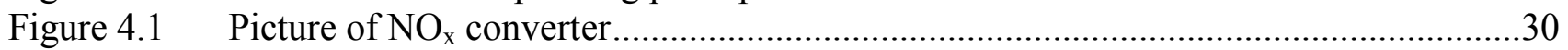

Figure 4.2 Comparison of the $\mathrm{NO}_{\mathrm{x}}$ converter efficiency with a flow rate of $3.0 \mathrm{lpm}$ at

temperatures of $300^{\circ} \mathrm{F}, 325^{\circ} \mathrm{F}$ and $350^{\circ} \mathrm{F}$ using Horiba catalyst. ...........................

Figure 4.3 Comparison of the $\mathrm{NO}_{\mathrm{x}}$ converter efficiency with a flow rate of $3.5 \mathrm{lpm}$ at

temperatures of $300^{\circ} \mathrm{F}, 325^{\circ} \mathrm{F}$ and $350^{\circ} \mathrm{F}$ using Horiba catalyst.

Figure 4.4 Comparison of the $\mathrm{NO}_{\mathrm{x}}$ converter efficiency with a flow rate of $3.0 \mathrm{lpm}$ at

temperatures of $300^{\circ} \mathrm{F}, 325^{\circ} \mathrm{F}$ and $350^{\circ} \mathrm{F}$ using Vitreous Carbon catalyst................

Figure 4.5 Comparison of the $\mathrm{NO}_{\mathrm{x}}$ converter efficiency with a flow rate of $3.5 \mathrm{lpm}$ at

temperatures of $300^{\circ} \mathrm{F}, 325^{\circ} \mathrm{F}$ and $350^{\circ} \mathrm{F}$ using Vitreous Carbon catalyst................35

Figure 7.1 Representation of exhaust flow rate and the error in measurement of exhaust flow

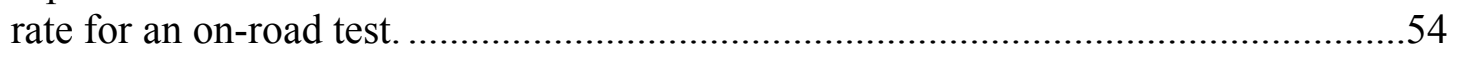

Figure 7.2 $\quad$ Effect of flow rate on the error in exhaust flow measurement. ...............................55

Figure 7.3 Effect of errors in exhaust flow measurement within the NTE region on brake-

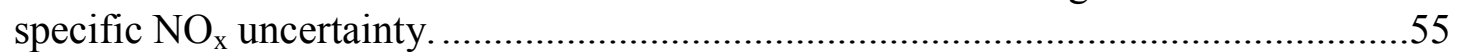

Figure 7.4 Effect of errors in $\mathrm{NO}_{\mathrm{x}} \mathrm{ppm}$ on $\mathrm{bsNO}_{\mathrm{x}}$ uncertainty. .......................................56

Figure 7.5 $\quad$ Representation of error in bsNO $_{x}$ emissions on an engine speed vs. engine load

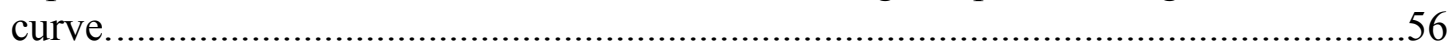

Figure 7.6 Representation of error in $\mathrm{bsCO}_{2}$ emissions on an engine speed vs. engine load

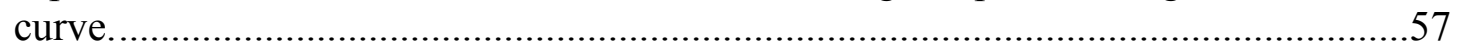

Figure 8.1 Time traces of vehicle speed, engine load, and engine speed for a SAB2BM route...61

Figure 8.2 Altitude profile for the SAB2BM route ........................................................62

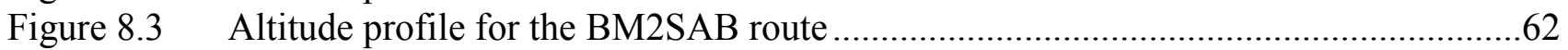

Figure 8.4 Time traces of vehicle speed, engine load, and engine speed for a BM2SAB route...63

Figure 8.5 $\quad$ Time traces of vehicle speed, engine load, and engine speed for a PA1 route...........64

Figure 8.6 Time traces of vehicle speed, engine load, and engine speed for a PA2 route...........65

Figure 8.7 Time traces of vehicle speed, engine load, and engine speed for a PA3 route...........66

Figure 8.8 Time traces of vehicle speed, engine load, and engine speed for a SAB2SW route. ...67

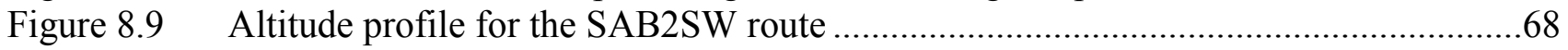

Figure 8.10 $\quad$ Altitude profile for the SW2SAB route . ........................................................68

Figure 8.11 Time traces of vehicle speed, engine load, and engine speed for a SW2SAB route. ...69

Figure 8.12 Acceleration and deceleration rates both in the NTE and non-NTE regions..............70

Figure 8.13 Time traces of vehicle speed, engine load, engine speed, $\mathrm{bsCO}_{2}$ and $\mathrm{bsNO}_{\mathrm{x}}$ during a

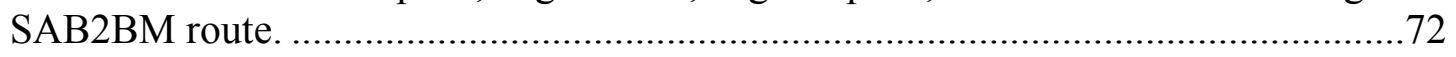

\begin{tabular}{|lll|l|}
\hline Figure 8.14 Time traces of vehicle speed, engine load, engine speed, $\mathrm{bsCO}_{2}$ and $\mathrm{bsNO}_{\mathrm{x}}$ during a \\
\hline
\end{tabular}

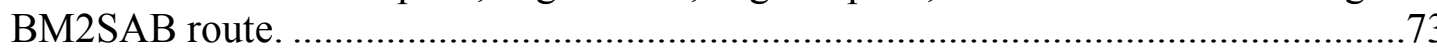

Figure 8.15 Time traces of vehicle speed, engine load, engine speed, $\mathrm{bsCO}_{2}$ and $\mathrm{bsNO}_{\mathrm{x}}$ during

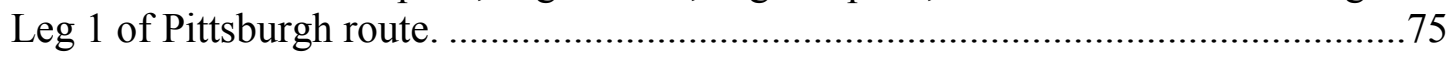

Figure 8.16 Time traces of vehicle speed, engine load, engine speed, $\mathrm{bsCO}_{2}$ and $\mathrm{bsNO}_{\mathrm{x}}$ during

Leg 2 of Pittsburgh route. .......................................................................... 
Figure 8.17 Time traces of vehicle speed, engine load, engine speed, $\mathrm{bsCO}_{2}$ and $\mathrm{bsNO}_{\mathrm{x}}$ during Leg 3 of Pittsburgh route. ........................................................................ 77

Figure 8.18 Time traces of vehicle speed, engine load, engine speed, $\mathrm{bsCO}_{2}$ and $\mathrm{bsNO}_{\mathrm{x}}$ during

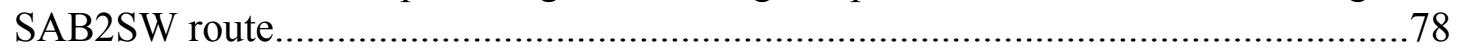

Figure 8.19 Time traces of vehicle speed, engine load, engine speed, $\mathrm{bsCO}_{2}$ and $\mathrm{bsNO}_{\mathrm{x}}$ during

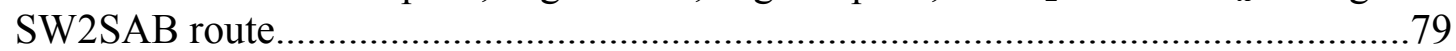

Figure 8.20 Distribution of acceleration, cruise and deceleration modes with respect to time spent in the NTE region on different routes..................................................... 80

Figure 8.21 Average modal emission rate of $\mathrm{NO}_{\mathrm{x}}$ on different routes for Engine A...................81

Figure 8.22 Two-dimensional representation of variation of $\mathrm{bsNO}_{\mathrm{x}}$ as function of engine speed and engine torque.....

\begin{tabular}{|lll|l|}
\hline Figure 8.23 Three dimensional representation of variation of $\mathrm{bsNO}_{\mathrm{x}}$ as function of engine speed & The \\
\hline
\end{tabular}

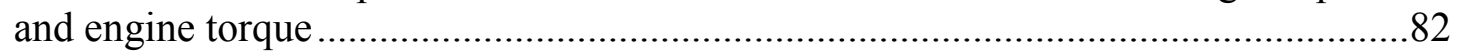

Figure 8.24 Comparison of Time in NTE and 30s windows on different routes ........................84

Figure 8.25 Comparison of percentage of 30s windows in NTE region and total time .................84 Figure 8.26 Comparison of percentage of 30s windows with $\mathrm{bsNO}_{\mathrm{x}}$ exceeding NTE limit in NTE

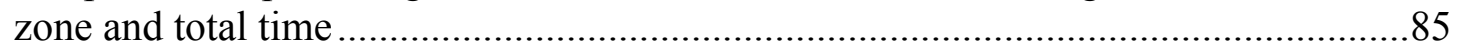

\begin{tabular}{|c|c|}
\hline Figure 8.27 & 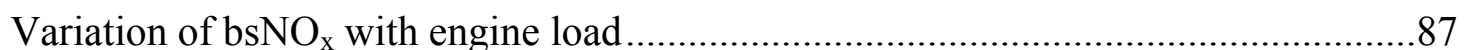 \\
\hline
\end{tabular}

Figure 8.28 Comparison of engine load in NTE region, when $\mathrm{bsNO}_{\mathrm{x}}$, is within NTE limits and

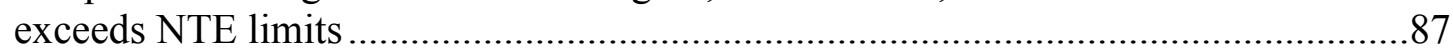

Figure 8.29 Variation of bsNO ${ }_{\mathrm{x}}$ with engine speed ..........................................................8

Figure 8.30 Comparison of engine speed in NTE region, when $\mathrm{bsNO}_{\mathrm{x}}$, is within NTE limits and

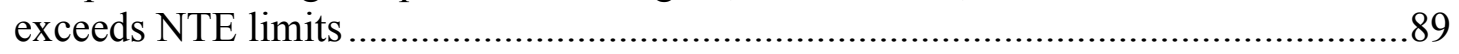

Figure $8.31 \quad$ Variation of bsNO ${ }_{x}$ with engine power .....................................................90

Figure 8.32 Comparison of engine power in NTE region when $\mathrm{bsNO}_{\mathrm{x}}$, is within NTE limits and

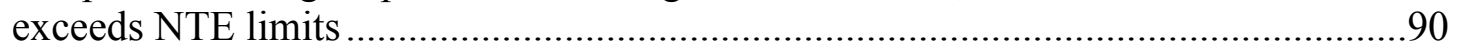

Figure A-1 Three-dimensional representation of variation of $\mathrm{NTE} \mathrm{bsNO}_{\mathrm{x}}$ as function of engine

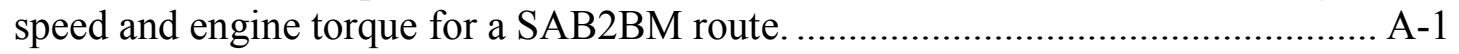

Figure A-2 Three-dimensional representation of variation of $\mathrm{NTE} \mathrm{bsNO}_{\mathrm{x}}$ as function of engine speed and engine power for a SAB2BM route. ....................................... A-1

Figure A-3 Three-dimensional representation of variation of NTE $b_{s N O}$ as function of engine load and engine power for a SAB2BM route............................................ A-2

Figure A-4 Three-dimensional representation of variation of $\mathrm{NTE}_{\mathrm{bSNO}}$ as function of engine

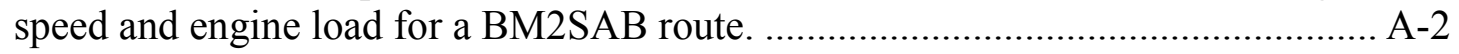

Figure A-5 Three-dimensional representation of variation of $\mathrm{NTE} \mathrm{bsNO}_{\mathrm{x}}$ as function of engine speed and engine power for a BM2SAB route. ....................................... A-3

Figure A-6 Three-dimensional representation of variation of $\mathrm{NTE}_{\mathrm{bsNO}}$ as function of engine load and engine power for a BM2SAB route......................................... A-3

Figure A-7 Three-dimensional representation of variation of $\mathrm{NTE}_{\mathrm{bsNO}}$ as function of engine

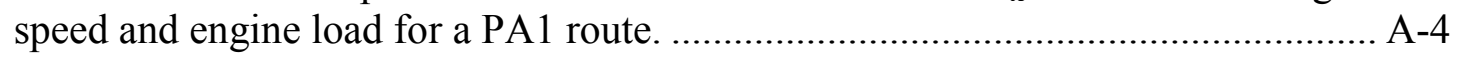

Figure A-8 Three-dimensional representation of variation of NTE $\mathrm{bsNO}_{\mathrm{x}}$ as function of engine speed and engine power for a PA1 route. .............................................. A-4

Figure A-9 Three-dimensional representation of variation of $\mathrm{NTE}_{\mathrm{bsNO}}$ as function of engine load and engine power for a PA1 route. .................................................. A -5

Figure A-10 Three-dimensional representation of variation of $\mathrm{NTE} \mathrm{bsNO}_{\mathrm{x}}$ as function of engine

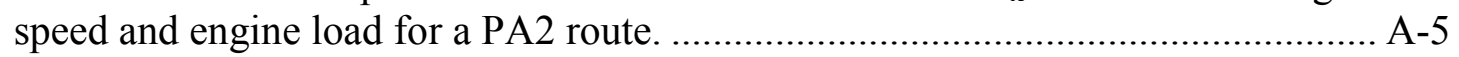

Figure A-11 Three-dimensional representation of variation of $\mathrm{NTE}_{\mathrm{bsNO}}$ as function of engine

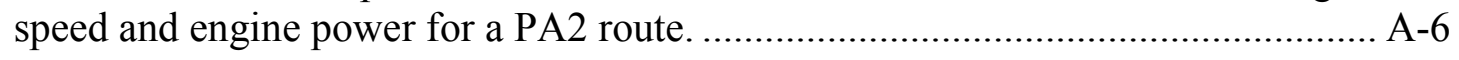


Figure A-12 Three-dimensional representation of variation of $\mathrm{NTE}_{\mathrm{bsNO}}$ as function of engine load and engine power for a PA2 route. ..................................................... A-6

Figure A-13 Three-dimensional representation of variation of NTE $\mathrm{bsNO}_{\mathrm{x}}$ as function of engine

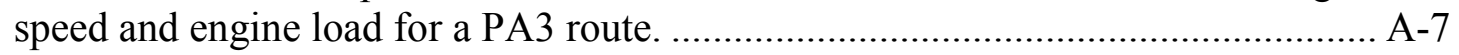

Figure A-14 Three-dimensional representation of variation of $\mathrm{NTE}_{\mathrm{bsNO}}$ as function of engine

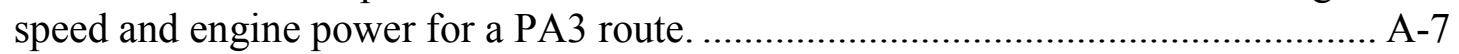

Figure A-15 Three-dimensional representation of variation of $\mathrm{NTE} \mathrm{bsNO}_{\mathrm{x}}$ as function of engine load and engine power for a PA3 route. .................................................... A-8

Figure A-16 Three-dimensional representation of variation of $\mathrm{NTE}_{\mathrm{bsNO}}$ as function of engine speed and engine power for a SAB2SW route........................................... A-8

Figure A-17 Three-dimensional representation of variation of $\mathrm{NTE}_{\mathrm{bsNO}}$ as function of engine speed and engine power for a SAB2SW route................................................ A-9

Figure A-18 Three-dimensional representation of variation of $\mathrm{NTE}_{\mathrm{bsNO}}$ as function of engine load and engine power for a SAB2SW route............................................. A -9

Figure A-19 Three-dimensional representation of variation of $\mathrm{NTE}_{\mathrm{bsNO}}$ as function of engine speed and engine power for a SW2SAB route............................................ A-10

Figure A-20 Three-dimensional representation of variation of $\mathrm{NTE} \mathrm{bsNO}_{\mathrm{x}}$ as function of engine speed and engine power for a SW2SAB route.......................................... A-10

Figure A-21 Three-dimensional representation of variation of $\mathrm{NTE}_{\mathrm{bsNO}}$ as function of engine load and engine power for a SW2SAB route............................................ A-11 


\section{NOMENCLATURE}

\begin{tabular}{|c|c|}
\hline AEI & Analytical Engineering, Inc. \\
\hline bhp & Brake-horsepower \\
\hline bhp-hr & Brake-Horsepower-hour \\
\hline $\mathrm{BM} 2 \mathrm{SAB}$ & Bruceton Mills to Sabraton \\
\hline $\mathrm{bsCO}_{2}$ & Brake-Specific $\mathrm{CO}_{2}$ \\
\hline $\mathrm{bsNO}_{\mathrm{x}}$ & Brake-Specific $\mathrm{NO}_{\mathrm{x}}$ \\
\hline CARB & California Air Resources Board \\
\hline CDL & Commercial Driver's License \\
\hline CE-CERT & College of Engineering-Center for Environmental Research and Technology \\
\hline CFR & Code of Federal Regulations \\
\hline $\mathrm{CO}_{2}$ & Carbon Dioxide \\
\hline$\Delta \mathrm{P}$ & Differential Pressure \\
\hline $\mathrm{EC}$ & Electrochemical \\
\hline ECU & Electronic Control Unit \\
\hline EERC & Engine and Emissions Research Center \\
\hline EPA & Environmental Protection Agency \\
\hline $\mathrm{F}_{\mathrm{AA}}$ & Thermal Expansion Correction Factor \\
\hline $\mathrm{F}_{\mathrm{G}}$ & Specific Gravity Correction Factor \\
\hline $\mathrm{F}_{\mathrm{L}}$ & Location Correction Factor \\
\hline $\mathrm{F}_{\mathrm{M}}$ & Manometer Correction Factor \\
\hline $\mathrm{F}_{\mathrm{NA}}$ & Unit Correction Factor \\
\hline $\mathrm{F}_{\mathrm{RA}}$ & Reynolds Number Correction Factor \\
\hline $\mathrm{F}_{\mathrm{tb}}$ & Temperature Correction Factor \\
\hline $\mathrm{F}_{\mathrm{tf}}$ & Flowing Temperature Correction Factor \\
\hline $\mathrm{F}_{\mathrm{pb}}$ & Pressure Base Factor \\
\hline $\mathrm{F}_{\mathrm{pv}}$ & Supercompressibility Factor \\
\hline FTP & Federal (Transient) Test Procedure \\
\hline $\mathrm{G}$ & Grams \\
\hline GPS & Global Positioning Sensor \\
\hline HDDE & Heavy Duty Diesel Engine \\
\hline $\mathrm{h}_{\mathrm{w}}$ & Differential pressure as measured by the Annubar primary element \\
\hline hr & Hour \\
\hline K & Flow Coefficient \\
\hline LFE & Laminar Flow Element \\
\hline MEMS & Mobile Emissions Measurement System \\
\hline NDIR & Non-dispersive Infrared \\
\hline NDUV & Non-dispersive Ultraviolet \\
\hline NESCAUM & Northeast Sates for Coordinated Air Use Management \\
\hline
\end{tabular}


NIST National Institute of Standards and Technology

NO Nitric Oxide

$\mathrm{NO}_{2} \quad$ Nitrogen Dioxide

$\mathrm{NO}_{\mathrm{x}} \quad$ Oxides of Nitrogen

NTE Not-to-Exceed

$\mathrm{O}_{2} \quad$ Oxygen

OBD On-board Diagnostic

$\mathrm{P}_{\mathrm{f}} \quad$ Flowing Pressure or Absolute Pressure

$\mathrm{Q}_{\mathrm{s}} \quad$ Volumetric Flow Rate

RAVEM Ride Along Vehicle Emissions Measurement System

ROVER Real-time On-road Vehicle Emissions Reporter

SAB2BM Sabraton to Bruceton Mills

SAB2SW Sabraton to Saltwell

S-HDDE Settling Heavy-Duty Diesel Engine Manufacturers

SW2SAB Saltwell to Sabraton

$\mathrm{T} \quad$ Temperature

TEC Thermo Electric Chiller

VITO Flemish Institute for Technological Research

VOEM VITO's On-the-road Emission and Engine Measurement

WVU West Virginia University

$\mathrm{Y}_{\mathrm{A}} \quad$ Gas Expansion Factor

$\mathrm{ZrO}_{2} \quad$ Zirconium Oxide 


\section{INTRODUCTION}

Diesel engines dominate both on-highway and non-road heavy-duty vehicles, and now comprise of a growing share of light-duty vehicles. It is estimated that by 2007 , the emissions from heavy-duty trucks and buses will account for as much as 30 percent of oxides of nitrogen emissions from mobile sources and 14 percent of particulate matter emissions [1]. In order to minimize the effect of these emissions, the United States Environmental Protection Agency (US EPA) has required heavy-duty diesel engine manufacturers to produce engines that are in compliance with emissions specifications set forth by the agency. Emissions from these heavyduty engines are currently measured in accordance with the requirements of 40 CFR Part 86, Subpart N [2]. In the future, US EPA and other state regulating bodies will require the engine manufacturers to measure in-use emissions from vehicles under "real-world" operating conditions.

The first step towards curbing vehicle emissions was taken back in year 1970, when the Congress, in view of the rising concerns over the effects of environmental pollution, passed the Clean Air Act [7], which requires the Environmental Protection Agency (EPA) to:

- Review public health standards for six major pollutants every five years.

- Update standards, if necessary, to "protect public health with an adequate margin of safety," based on the latest, best-available science.

- Consider only the public health, and not costs of compliance, when setting air quality standards- and save cost considerations for the implementation phase.

Since the 1970's, EPA has required motor vehicle manufacturers to reduce $\mathrm{NO}_{\mathrm{x}}$ emissions from cars and trucks. Reductions achieved through auto emissions control have been significant. In the last ten years, $\mathrm{NO}_{\mathrm{x}}$ emissions from highway vehicles decreased by more than 5 percent, while vehicle miles traveled increased significantly. EPA and states continue to examine vehicle emissions-testing programs to ensure that readings accurately reflect emissions levels. The EPA describes various emissions standards and test procedures in order to certify these engines.

Current federal regulation requires certification of engines earmarked for heavy-duty diesel vehicles. The certification requires emissions testing over the Transient FTP dynamometer cycle (CFR Title 40, Part 86.1333) and that emission be expressed in $\mathrm{g} / \mathrm{bhp}-\mathrm{hr}$. The testing is to be performed in a controlled laboratory environment where the engine dynamometer is used to load or motor the engine through the specified transient cycle. The raw exhaust is routed to a 
full-scale dilution tunnel, the constant volume sampler (CVS) where the raw exhaust is mixed with dilution air to simulate the real-world interaction of a vehicle's exhaust with the atmosphere. The use of a CVS eliminates problems associated with measuring the raw exhaust mass flow rates because only the mass flow rate of the diluted stream in the tunnel is needed for emissions calculations.

An alternative to engine dynamometer testing is the chassis dynamometer testing. The chassis dynamometer testing is performed with the engine in the vehicle, but the vehicle itself placed on the test bed. During testing the vehicle is driven through cycles as if it were being driven on the road, simulating on-road test routes. The sampling systems and the emissions measurement systems are similar to laboratory testing described earlier.

Future regulations would require the testing of vehicle emissions under "real-world" conditions. Such in-use testing would require an On-Road Emissions Measurement System (OREMS) that would be transported along with the vehicle as it is driven. OREMS for heavyduty diesel fueled vehicles presents a challenge, but various universities and institutions have performed a considerable amount of research in developing a portable and mobile emissions measurement system, which are discussed in chapter 2.

West Virginia University (WVU) developed an OREMS called the Mobile Emissions Measurement System (MEMS) to measure in-use, brake-specific emissions from heavy-duty diesel powered vehicles. The MEMS was approved by the US EPA to be used for the Consent Decrees work [3 45]. WVU was required to perform the overall study, which was divided into four phases. Phase I consisted of evaluating current available technology to determine if any system was capable of meeting the requirements of an OREMS. A new system had to be integrated if no such systems were found. Phase II involved representative routes to test heavyduty diesel powered vehicles with an OREMS during their in-use, on-road operations. Phase III and Phase IV of the project was actual testing with Phase III including engines manufactured from 1988 to 2001 and Phase IV includes engines manufactured after 2001 by the different engine manufacturers.

\subsection{Objective}

The global objective of this study was to measure in-use emissions from heavy-duty diesel vehicles using the Mobile Emissions Monitoring System (MEMS), an on-board emissions measurement system developed at West Virginia University (WVU). This study reflects a part of work that was conducted at WVU to satisfy the in-use emissions evaluation as mandated by the 
Consent Decrees, which requires the Settling Heavy-duty Diesel Engine manufacturers (SHDDE) to conduct emissions testing on a variety of their in-service diesel engines to characterize real-world emissions from such diesel engines. The purpose of this testing was to establish a baseline emission database on a wide range of pre-model year (MY) 1998 in-use engines of varying age and service characteristics in order to demonstrate the effectiveness of the changes that are required to be to MY2000 made engines produced in accordance with the Consent Decrees. The specific objectives of this study were as follows:

- Perform an uncertainty analysis on the MEMS in order to know the maximum possible error in the measurement of emissions.

- Randomly select test vehicles from the in-use population that were powered by engines ranging from 1988 through 1998 model years. This selection process included acquisition of the targeted vehicles, vehicle inspection (to ensure safety during in-use emissions testing exercise), and MEMS installation.

- Conduct a mix of on-road and laboratory testing. This study will only discuss the on-road component. Details of on laboratory testing may be found elsewhere [6]. On-road tests included only those routes that were developed during Phase II and approved by the US EPA. $\mathrm{NO}_{x}$ and $\mathrm{CO}_{2}$ emissions results were to be presented on a brake specific mass basis.

- Laboratory testing involved engine dynamometer testing of engines that were removed from a select number of vehicles. These dynamometer-based tests included transient and steady state modes of operation, with engine emissions measured using a MEMS unit and laboratory-grade analyzers. Such correlation testing (or concurrent testing) was used to establish measurement accuracy of the MEMS. Two transient test cycles were utilized: the traditional FTP test cycle and a simulated engine dynamometer cycle that was derived from data collected during one of the on-road tests. A steady-state cycle that exercised the engine at operating conditions of peak horsepower and peak torque was also used.

- Present a comprehensive data set of in-use brake-specific mass emissions from vehicles driven over different routes and driving conditions.

- Describe the episodic nature of vehicle emissions over different routes and different driving conditions. 
- Characterize the nature of emissions based on engine parameters such as engine speed, engine load and engine power.

- Attempt to create a compliance factor for in-use emissions based on $\mathrm{NO}_{x} / \mathrm{CO}_{2}$ ratio. The use of $\mathrm{NO}_{x} / \mathrm{CO}_{2}$ ratio would reduce the uncertainties due to flow measurement. 


\section{REVIEW OF LITERATURE}

\subsection{History of Engine Certification}

In early 1970's, the EPA developed a study named CAPE-21, with the objective to assess vehicle emissions. Various vehicle configurations were examined, including gasoline- and diesel-fueled engines, tandem axle trucks and tractor-trailer trucks. The on-board data from each vehicle was obtained digitally. The data was then collected and reduced to develop test cycles including, the EPA Urban Dynamometer Driving Schedule (UDDS) for heavy-duty vehicles, and the New York bus, truck and composite cycles. The Federal Test Procedure (FTP) transient test was developed from the same database that was used to develop the UDDS. The FTP transient test was developed to take into account the variety of heavy-duty truck and buses in American cities, including traffic in and around the cities on roads and expressways. The cycle includes "motoring" segments and, therefore, requires a DC or AC electric dynamometer capable of both absorbing and supplying power.

The transient cycle consists of four phases: the first is a NYNF (New York Non Freeway) phase typical of light urban traffic with frequent stops and starts, the second is LANF (Los Angeles Non Freeway) phase typical of crowded urban traffic with few stops, the third is a LAFY (Los Angeles Freeway) phase simulating crowded expressway traffic in Los Angeles, and the fourth phase repeats the first NYNF phase. It comprises a cold start after parking overnight, followed by idling, acceleration and deceleration phases, and a wide variety of different speeds and loads sequenced to simulate the running of the vehicle that corresponds to the engine being tested. There are few stabilized running conditions, and the average load factor is about 20 to $25 \%$ of the maximum horsepower available at a given speed.

The engine is exercised through the FTP twice and the second run is a "hot start" after a pause in engine operation for $1200 \mathrm{~s}(20 \mathrm{~min})$ on completion of the first cycle. The variation of normalized speed and torque with time is shown in Figure 2.1 2 27].

However, it is well recognized that the FTP is not an accurate representation of a vehicle's operation on road under present-day driving conditions. The regulated emissions limits for an engine operating on FTP cycle for different engine model years are given in [able 2-1 ]. 


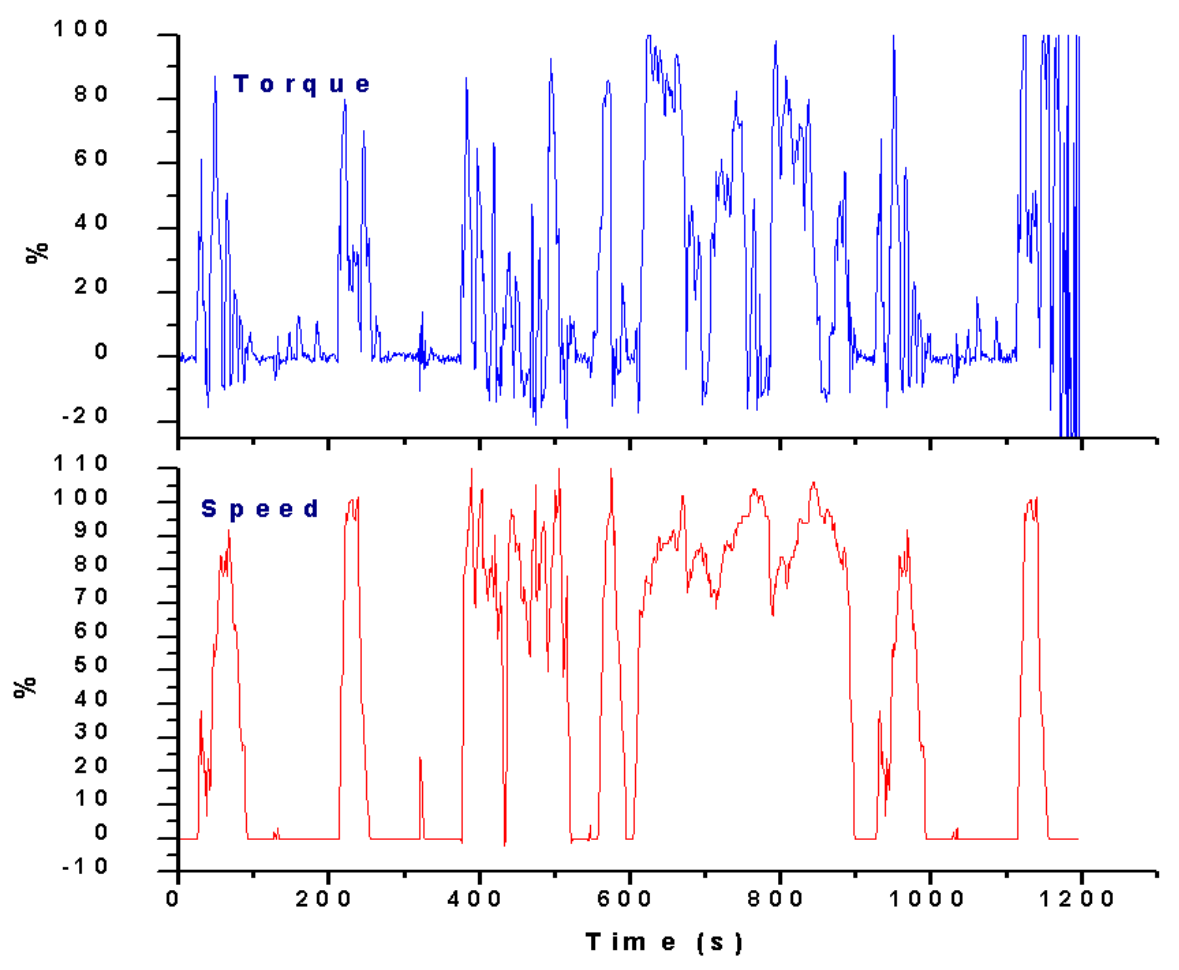

Figure 2.1 Representation of speed and torque set points for a FTP cycle [7].

Table 2-1 Emissions standards for Heavy-Duty diesel engine.

\begin{tabular}{|c||c||c|c|c||}
\hline \hline Year & HC (g/bhp-hr) & CO (g/bhp-hr) & NO $_{\mathbf{x}}$ (g/bhp-hr) & PM (g/bhp-hr) \\
\hline \hline 1990 & 1.3 & 15.5 & 6.0 & 0.60 \\
\hline \hline 1991 & 1.3 & 15.5 & 5.0 & 0.25 \\
\hline \hline 1994 & 1.3 & 15.5 & 5.0 & 0.10 \\
\hline \hline 1998 & 1.3 & 15.5 & 4.0 & 0.10 \\
\hline
\end{tabular}

\subsection{Need for additional emissions testing requirements}

Alleged modifications in the engine fuel control strategies when a vehicle is operating on the road over those when the engine is tested on the EPA prescribed Transient FTP cycle, and the resulting production of higher levels of $\mathrm{NO}_{\mathrm{x}}$ emissions when operating under actual on-road conditions makes it essential that an "in-use emissions testing" program be developed to complement the FTP schedule. 


\subsection{Need for On-road Measurement systems}

Although there have been significant advances in capabilities of modern engine and chassis dynamometers, gas analyzers in emissions testing laboratories, still there may be no substitute for in-field testing. Tunnel studies and on-road data have indicated that emissions differ significantly from those predicted by emissions models [8]. Hence, an in-use testing program in agreement with the engine manufacturers was developed, which is called the Consent Decrees.

\subsection{Consent Decrees}

The EPA, declared the ECM controlled injection timing strategies used by the manufacturers were actually "defeat devices" by stating,

"Section 203 (a) (3) (b) of the Clean Air Act (CAA), 42 U.S.C. Sec. 752(a)(3)(b) prohibits the manufacture, selling or installation of any device that bypasses, defeats or renders inoperative a required element of the vehicle's emission control system".

In October 1998, the six S-HDDE namely: Caterpillar, Inc.; Cummins Engine Company, Inc.; Detroit Diesel Corporation, Inc.; Mack Trucks, Inc.; International Truck and Engine Corporation, Volvo Trucks, Inc., entered into individual agreements with the US EPA, Department of Justice, and CARB. These are referred to as the Consent Decrees [9].

The Consent Decrees require that the vehicles used for testing shall be a representative of the mix of mileages within the Useful Life of the engines, and shall be tested in a manner consistent with the test procedures and driving routes identified in the Phase II of this project 4 . It should be noted that the Consent Decree was different for each manufacturer. The Consent Decrees requires that the engines must meet the Not-to-Exceed (NTE) limits, which are described in the next section.

\subsection{NTE definition for Gaseous Emissions}

The US EPA and CARB have defined the Not-to-Exceed (NTE) zones of operation for certification as shown in

Figure 2.2 The NTE zone is defined in the Consent Decrees as bounded by engine speeds $15 \%$ above the ESC Speeds (European Stationary Cycle), engine loads greater than $30 \%$ of maximum, and engine power greater than $30 \%$ of maximum. The ESC speed is calculated as follows 10]:

$$
\eta_{15 \% \text { ESC Speed }}=\eta_{l o}+0.15\left(\eta_{h i}-\eta_{l o}\right)
$$


where $\eta_{10}$ is the lowest engine speed at which $50 \%$ of the maximum power is available and $\eta_{h i}$ is the highest engine speed where $70 \%$ of the maximum power occurs.

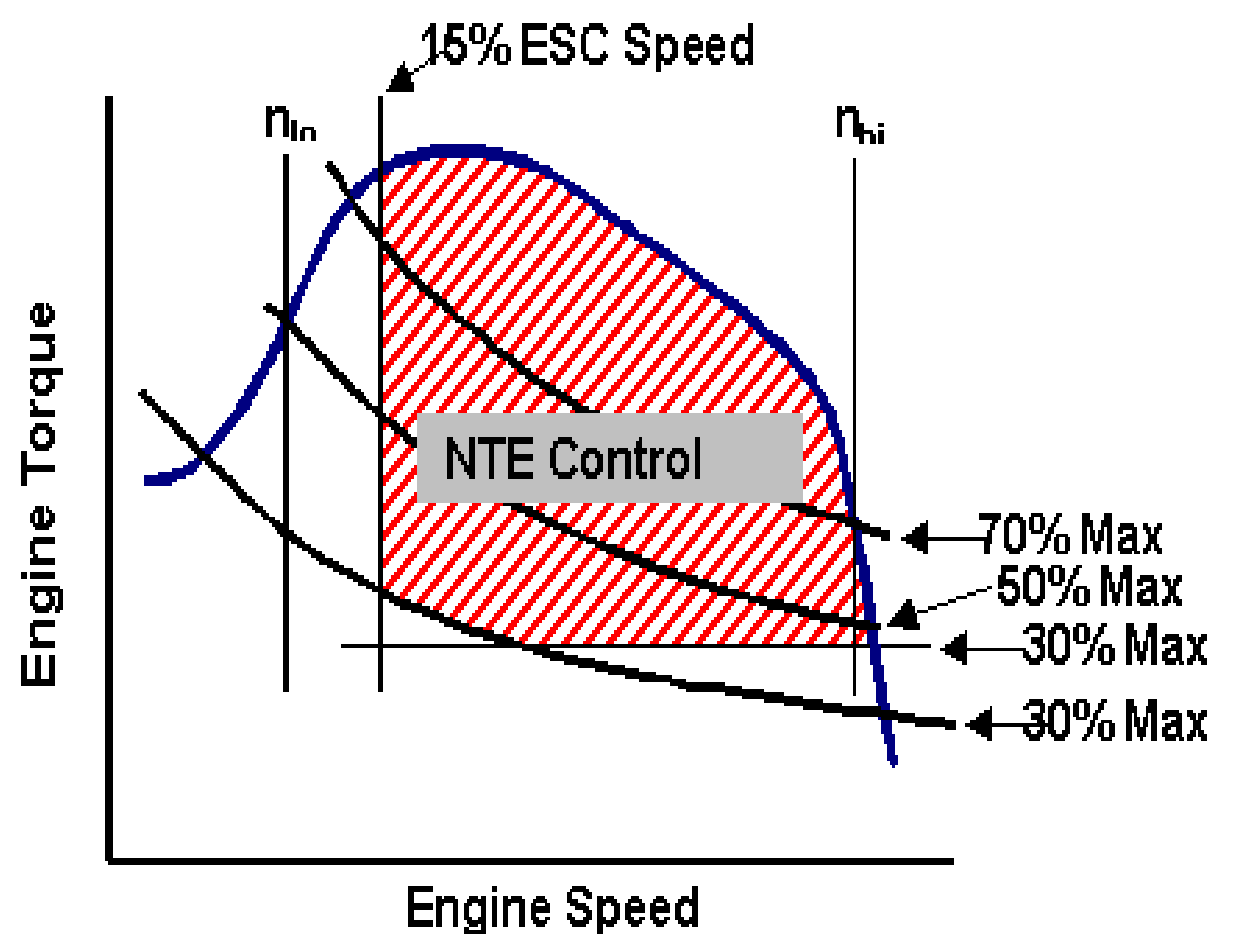

Figure 2.2 Graphical definition of NTE zone for gaseous emissions. [10]

The original Consent Decrees defined that a valid NTE sample shall contain engine operation in the NTE zone for a period of at least 30 consecutive seconds. The modified Consent Decrees state that a valid NTE sample shall contain engine operation within the NTE zone for a period of at least 30 consecutive seconds and shall include the entire NTE event until the engine drops out of the control area as defined. The average emissions for each valid sampling event will be calculated by dividing the total mass of emissions emitted during the duration of the NTE event by the work done during the duration of the NTE event by the work done during the NTE event. The allowed values of exhaust emissions in accordance with the Consent Decrees are given in Table 2-2 and Table 2-3. 
Table 2-2 HDDE emissions standard in compliance with the Consent Decrees

\begin{tabular}{|c|c|c|c|c|c|}
\hline & & $\begin{array}{c}\text { NO }_{\mathbf{x}} \\
(\mathrm{g} / \mathrm{bhp}-\mathrm{hr})\end{array}$ & $\begin{array}{c}\text { CO } \\
\text { (g/bhp-hr) }\end{array}$ & $\begin{array}{c}\text { HC } \\
\text { (g/bhp-hr) }\end{array}$ & $\begin{array}{c}\text { PM } \\
\text { (g/bhp-hr) }\end{array}$ \\
\hline $\begin{array}{c}\text { Euro III } \\
\text { Composite } \\
\text { Value } \\
\text { Limit }\end{array}$ & $\begin{array}{c}\text { After } \\
\text { Dec 31, } \\
1998\end{array}$ & $\begin{array}{l}6.0 \text { (or) } \\
1.5^{*} \text { FTP } \\
\text { Standard }\end{array}$ & 15.5 & 1.3 & 0.10 \\
\hline NTE Limit & $\begin{array}{l}\text { After } \\
\text { Dec 31, } \\
1998\end{array}$ & $\begin{array}{c}7.0 \text { (or) } \\
1.75^{*} \text { FTP } \\
\text { Standard }\end{array}$ & 15.5 & 1.3 & 0.10 \\
\hline
\end{tabular}

Table 2-3 HDDE emissions standards for Post 2001 engines

\begin{tabular}{|c|c|c|c|c|c|c|}
\hline & & $\begin{array}{r}\mathrm{NO}_{\mathrm{x}}+ \\
(\mathrm{g} / \mathrm{b}\end{array}$ & $\begin{array}{l}\text { NMHC } \\
\text { p-hr) }\end{array}$ & $\begin{array}{c}\text { CO } \\
\text { (g/bhp-hr) }\end{array}$ & $\begin{array}{c}\text { HC } \\
\text { (g/bhp-hr) }\end{array}$ & $\begin{array}{c}\text { PM } \\
\text { (g/bhp-hr) }\end{array}$ \\
\hline FTP Limit & $\begin{array}{l}\text { fter } \\
\text { Oct 1, } \\
2002\end{array}$ & 2.4 & $\begin{array}{c}2.5 \text { (if } \\
\text { NMHC }< \\
0.5 \\
\text { g/bhp-hr) }\end{array}$ & 15.5 & 1.3 & 0.10 \\
\hline $\begin{array}{l}\text { Euro III } \\
\text { Composite } \\
\text { Value } \\
\text { Limit }\end{array}$ & $\begin{array}{l}\text { fter } \\
\text { Oct 1, } \\
2002\end{array}$ & $\begin{array}{l}2.4 \text { (or) } \\
1.0 * \text { FTP } \\
\text { Standard }\end{array}$ & $\begin{array}{c}2.5 \text { (if } \\
\text { NMHC }< \\
0.5 \\
\text { g/bhp-hr) }\end{array}$ & 15.5 & 1.3 & 0.10 \\
\hline $\begin{array}{l}\text { NTE } \\
\text { Limit }\end{array}$ & $\begin{array}{l}\text { fter } \\
\text { Oct 1, } \\
2002\end{array}$ & $\begin{array}{l}3.0 \text { (or) } \\
1.25^{*} \text { FTP } \\
\text { Standard }\end{array}$ & $\begin{array}{c}3.125 \text { (if } \\
\text { NMHC < } \\
0.625 \\
\text { g/bhp-hr) }\end{array}$ & 15.5 & 1.3 & $\begin{array}{l}0.125 \text { (or) } \\
1.25^{*} \text { FTP } \\
\text { Standard }\end{array}$ \\
\hline
\end{tabular}

\subsection{Additional Compliance Requirements}

Subject to the provisions of the Consent Decrees, in the future-the Heavy-duty diesel engine manufacturers shall not employ a defeat device in any electronically controlled Truck Heavy-Duty Diesel Engine manufactured on or after December 31, 1998.

- Civil penalties were imposed on the engine manufacturers.

- The manufacturers were also required to allocate funds for pollution research.

- The manufacturers were required to upgrade existing engines to lower $\mathrm{NO}_{\mathrm{x}}$ emissions.

- Meet the 2004 emissions standards by October 2002, 15 months ahead of time.

- The engines were subjected to additional certification tests. 


\subsection{Engines subjected to the Consent Decrees}

The affected engine families from each of the manufacturer are listed in the Appendix of each of the Consent Decrees.

\subsection{Previous Mobile Systems for In-field Testing}

The need to measure real-world emissions in order to complement laboratory emissions tests spurred the design and development of on-board emissions monitoring. Various parameters such as size, weight, power requirements, initial and operating costs, robustness, reliability, installation time, the level of required modifications to the test vehicle, the measurement accuracy and precision were considered when the in-use systems were designed and developed. The majority of these early systems were used for testing engines that were employed in underground mining applications. The following sections summarize some of the past and current systems available for in-field testing.

\subsubsection{Southwest Research Institute-1983}

An emissions measurement system to measure emissions from diesel engines used in mining operations was developed by Southwest Research Institute [11. The system comprised of an engine dynamometer, laboratory grade emissions instruments, a volumetric fuel flow meter, and a laminar air flow meter to measure intake flow. A heated flame ionization detector was used for $\mathrm{HC}$ measurements, NDIR detectors for $\mathrm{CO}$ and $\mathrm{CO}_{2}$, a chemiluminescent analyzer for $\mathrm{NO}_{\mathrm{x}}$ measurements and a polaragraphic analyzer for $\mathrm{O}_{2}$ measurements. A mini-dilution tunnel was used to collect Particulate matter. The underground mining engines were laboratory tested to measure emissions, and also in-field testing were performed and analyses were made on the induced faults on diesel engine emissions. The results from the tests showed that engine faults could be detected from emissions data. The system lacked portability and was incapable of performing on-board emissions testing.

\subsubsection{Michigan Technological University-1992}

A system was developed for the measurement of emissions from diesel engines used in underground mining at the Michigan Technological University, called EMA (Emissions Measurement Apparatus) [12]. The EMA consisted of an exhaust dilution system and a portable instrument package. An air ejector is used to mix compressed nitrogen or air to the exhaust in order to dilute and cool the exhaust sample, to a predetermined dilution ratio. The EMA can measure PM emissions using a mini-dilution tunnel and the gaseous emissions concentrations of $\mathrm{CO}, \mathrm{CO}_{2}, \mathrm{NO}$ and $\mathrm{NO}_{2}$ with a bag system, at a single load and speed engine condition. Water 
condensation was prevented by the use of heated sampling lines. The parameters determined were fuel/air ratio, mass flow rates of fuel, air and exhaust emissions, and engine brake torque and horsepower. The parameters calculated were used for characterizing the engine load when performing EMA in-field tailpipe sampling, and for detecting deteriorated engines. The results of the portable analyzer measurements compared to laboratory-grade equipment showed to be within 5\% for $\mathrm{CO}_{2}, 10 \%$ for $\mathrm{CO}, 5 \%$ for $\mathrm{NO}$ and $7 \%$ for PM. The system could not be classified as an OREMS, for it was heavy and incapable of recording transient engine operations.

\subsubsection{University of Minnesota - 1997}

Researchers at the University of Minnesota developed the Emissions-Assisted Maintenance Procedure (EAMP) for diesel-powered mining equipment [13]. In the field the engine was loaded by stalling the vehicle's torque converter or hydraulic transmission. It could not be used on vehicles with manual transmissions. Electrochemical gas sensors were found suitable because of their ruggedness and portability. The objective of the EAMP system was to detect engine faults to determine if any engine maintenance was required. A portable gas analyzer was used to measure CO to establish any need for maintenance. The testing consisted of four parts: loading the engine against stalled torque converter, measuring the emissions while the engine operated under load, recording the generated data, and reducing that data to determine the condition of the engine.

\subsection{On-Board systems}

\subsubsection{Caterpillar, 1982}

Caterpillar designed a portable bag collection system to fulfill the requirements of Pointof-use Control, in order to determine fuel specific $\mathrm{NO}_{\mathrm{x}}$ emissions from in-use diesel engines [14]. That is manufacturers would label engines that comply with all applicable standards and this system would be used to verify its compliance. The system consists of a stainless steel sample probe, high temperature prefilter, insulated non-reactive sample line, a stainless steel sample pump, an air-cooled condensing coil, and two non reactive e sample bags. Water vapor in the sample was removed with a drying system, before being collected in the bags. A 24 VDC vehicle battery powers the system. The vehicle operator can remotely control the bag fill operations.

\subsubsection{Southwest Research Institute, 1992}

Southwest Research Institute developed a portable on-board emission measuring system

for diesel emissions from buses [15]. The objective was to perform testing without the use of a 
chassis dynamometer. The limitations to this testing was that the test vehicles were to be with automatic transmissions. Raw exhaust gaseous sample was collected over a 30 -second period. Energy Efficiency Systems, Inc. Enerac 200E was used to measure the concentrations of CO, $\mathrm{CO}_{2}, \mathrm{NO}_{\mathrm{x}}$ and $\mathrm{O} 2$ from the bag sample. The particulate matter on the dilute sample was collected on a Flurocarbon coated glass fiber filters. The system was based on an integrated bag approach rather than a continuous sampling technique, hence does not qualify as an OREMS.

\subsubsection{General Motors, 1993}

The in-use emissions was measured for a gasoline-fueled 1989, 3.8-liter displacement Pontiac Bonneville SSE passenger car, instrumented and driven on various city and highway routes [16. The data acquisition system with a total weight of $400 \mathrm{lbs}$. consisted of five 12 -volt batteries, inverters, computers and five different analyzers and the system were contained within the trunk of the vehicle. The analyzers used were based on infrared technology. The $\mathrm{CO}$ and $\mathrm{CO}$ was measured using Horiba MEXA-311 GE. The MEXA-324GE was used to measure HC and CO. A Siemens Ultramat-22P analyzer was used to measure $\mathrm{HC}$ and $\mathrm{CO}$, with an additional Siemens analyzer to measure NO. A Draegger electrochemical analyzer monitored ambient levels of $\mathrm{CO}$ within the passenger compartment.

The exhaust flow rate was inferred from the intake flow measured using a Kurz flowmeter, using suitable relationships. Water from the sample was removed by passing the sample through the use of an ice-cooled trap. Dynamometer tests were performed using the UDDS cycle to characterize the emission rates of $\mathrm{HC}$ and $\mathrm{CO}$. Slow data collection rate and inability to record transient events were the major concerns. However, the system did provide some in-use emissions for spark-ignited engines.

\subsubsection{US Coast Guard, 1997}

The US Coast Guard developed a system for measuring emissions from marine vessels, listed non-road sources of air pollution [17]. The analyzer in the system was an Enerac 2000E analyzer from Energy Efficient Systems, Inc. used to measure concentrations of $\mathrm{CO}, \mathrm{NO}, \mathrm{NO}_{2}$, $\mathrm{SO}_{2}, \mathrm{O}_{2}$ and $\mathrm{HC}$. Shipboard testing was performed on three 820ft U.S Coast Guard Cutters (WPBs). Air intake flow meters and fuel flow meters were installed for exhaust flow calculations. Strain gauges epoxied onto the propeller shafts, transmits torque and speed by radio frequency to a power-measuring instrument by, Wireless Data Corporation. Due to space limitations the exhaust samples were taken immediately after the turbocompressor. Though 
emissions measurements were taken, the system proved to be too large and bulky and was not portable.

\subsubsection{Flemish Institute for Technological Research, 1997}

VITO, The Flemish Institute for Technological Research, performed on-board emission measurements with a system called VOEM [18] (Vito's On-the-road Emission and Energy Measurement system). The system comprised of NDIR analyzers to measure $\mathrm{CO}_{2}$ and $\mathrm{CO}$, and FID for $\mathrm{HC}$ concentration measurements, and a chemiluminescent analyzer to measure $\mathrm{NO}_{\mathrm{x}}$.

\subsubsection{Northeast States for Coordinated Air Use Management (NESCAUM), 1998}

NESCAUM in cooperation with U.S Generating Co., the US EPA, the Manufacturers of Emission Control Association (MECA), and the Massachusetts Department of Environmental Protection performed testing to measure in-use emissions of off road diesel vehicles, with a mini dilution tunnel and a five-gas analyzer, as well as a bag sampling system [19]. The exhaust sample was fed to the dilution tunnel through heated lines. PM was collected exiting the tunnel with $70 \mathrm{~mm}$ filters. The gaseous emissions measured included $\mathrm{NO}_{\mathrm{x}}, \mathrm{CO}$, total hydrocarbons (THC), and $\mathrm{CO}_{2}$. Fuel rate was inferred from $\mathrm{CO}_{2}$ levels. The system was unreliable and inaccurate, with $27 \%$ difference from research grade analyzers for $\mathrm{CO}, 12 \%$ difference for $\mathrm{NO}_{\mathrm{x}}$, and $22 \%$ difference for $\mathrm{HC}, 38 \%$ difference for $\mathrm{PM}$ and $9 \%$ for the fuel consumption calculation.

\subsubsection{Ford Motor Company and WPI-Microprocessor Systems. Inc., 1999}

Ford Motor Company and WPI-Microprocessor Systems. Inc. developed a Portable Realtime Emission Vehicular Integrated Engineering Workstation (PREVIEW), which samples the water-laden exhaust 20]. PREVIEW is a fully integrated system with its portability, ability to measure exhaust mass or concentration emissions $\left(\mathrm{CO}, \mathrm{CO}_{2}, \mathrm{NO}_{\mathrm{x}}\right.$, and $\left.\mathrm{HC}\right)$ and up to forty engine PCM parameters. PREVIEW also accepts auxillary inputs from on-board instrumentation like temperature sensors, accelerometers etc. The software on a laptop computer records the data available on a second-by-second basis for future analysis. The results from PREVIEW was compared with those obtained from dynamometer laboratory tests using conventional instrumentation during FTP and Highway Fuel Economy tests. The results showed agreements within $1.5 \%$ for $\mathrm{CO}_{2}, 3.4 \%$ for $\mathrm{CO}, 12.3 \%$ for $\mathrm{HC}$ and $0.4 \%$ for $\mathrm{NO}_{\mathrm{x}}$. The difference in $\mathrm{HC}$ measurement was attributed to the fact that NDIR analyzer was used in PREVIEW and FID in the lab. 


\subsubsection{University of Pittsburgh, 1999}

A portable, on-board mass emission monitoring system was developed at the University of Pittsburgh in 1997, and was used for on-road testing of 20 natural gas powered vans [21 22]. The monitoring system was expanded to measure real-world second-by-second mass emissions of $\mathrm{HC}, \mathrm{CO}$ and $\mathrm{NO}_{\mathrm{x}}$ on a variety of late-model heavy-duty vehicles. The analyzer used in the system was a "garage-grade" NDIR based RG240 five-gas analyzer from OTC SPX, which draws undiluted exhaust from the tailpipe, and calculates mass exhaust flow from engine operating data obtained via a Prolink 9000 diagnostic link from Microprocessor Systems Inc. The system was inexpensive and portable and could be easily installed on a variety of diesel and alternative fuel buses and trucks.

\subsubsection{EPA, 2000}

For the purpose of measuring on-road emissions from vehicles the EPA's Certification and Compliance Division (CCD) developed ROVER, which is Real-time On-road Vehicle Emissions Reporter [23. This was used to monitor vehicle emission compliance during actual in-use on-road driving. The systems consists of four main components: a sampling and flow meter which is attached to the vehicle's tailpipe, an exhaust emissions analyzer unit, a scan tool which serves as a decoder for the engine's computer outputs, and records the quantity of gaseous emissions - $\mathrm{HC}, \mathrm{CO}, \mathrm{CO}_{2}, \mathrm{NO}_{\mathrm{x}}$ and $\mathrm{O}_{2}$ in grams/mile and smoke while a vehicle is being operated, as well as fuel economy, engine parameters, engine air/fuel ratio, road grade, and physical location, all at a user-selectable rate. ROVER played a very important role in investigation of the diesel engine defeat devices, resulting in the Consent Decrees.

\subsubsection{Honda R\&D and Nicolet Instrument Corp., 2000}

Honda R\&D Americas, Ltd., Honda R\&D Co., Ltd., and Nicolet Instrument Corp. developed an FTIR- based emissions measuring system with the targeted components being $\mathrm{NMHC}, \mathrm{NO}_{\mathrm{x}}$ and $\mathrm{CO}$ [24]. The system was basically designed for measuring the real-world performance of light-duty gasoline powered vehicles. Intake air was sampled from the front of the vehicle and exhaust sample was drawn through a heated line inserted into the tailpipe. The sample was dried using a water-removal system and then passed directly into the gas cells of twin FTIR spectrometers. Three nickel-metal hydride battery cells through a DC-AC inverter supplied the system power. Effect of vehicle acceleration and vibration are the challenges facing this system. 


\subsubsection{Sensors Inc., 2002}

Sensors Inc. developed on-vehicle analysis systems for in-use testing of diesel vehicles [25. The system called SEMTECH-D (Sensors Emissions Measurement Technology) was designed to provide instant analysis of exhaust gas components including total hydrocarbons (THC), oxides of nitrogen $\left(\mathrm{NO}_{\mathrm{x}}\right)$, carbon monoxide $(\mathrm{CO})$ and carbon dioxide $\left(\mathrm{CO}_{2}\right)$. The SEMTECH systems use a "garage-grade" non-dispersive ultra violet spectroscopy to measure $\mathrm{NO}$ an $\mathrm{NO}_{2}$ constituents of $\mathrm{NO}_{\mathrm{x}}$ simultaneously and independently. The exhaust flow is calculated using a hot-wire anemometer. The system can be rack or cart mounted. The system requires two connections with the vehicle tested. One is to the tailpipe to draw exhaust sample and the other is to the vehicle's diagnostic connector, provides the system access to the vehicle's data stream.

\subsubsection{Keio University}

A study was performed using a simple on-board emissions measurement system of actual $\mathrm{NO}_{\mathrm{x}}$ emissions of a medium duty freight vehicle 26. The $\mathrm{NO}_{\mathrm{x}}$ mass emissions were calculated by using Zirconia $\mathrm{NO}_{\mathrm{x}}$ sensor and Karman vortices sensor. Engine power was estimated from multiplying vehicle speed by a running resistance that can be calculated from rolling resistance, airflow resistance, climbing resistance and acceleration resistance. The study demonstrated that on-board measurement system could be used to evaluate road infrastructure, driver's operation, and vehicle running conditions, $\mathrm{NO}_{\mathrm{x}}$ and $\mathrm{CO}_{2}$ emissions.

\subsubsection{University of Alberta}

An on-board system was developed to measure and record ambient conditions, driving behavior, vehicle operating parameters, fuel consumption and exhaust emissions [27]. The system employs a Vetronix PXA-1100 five-gas analyzer, which uses a combination of infrared absorption and fast response chemical cells to measure $\mathrm{NO}_{\mathrm{x}}, \mathrm{CO}, \mathrm{CO}_{2}$ and $\mathrm{O}_{2}$. Air mass consumption rate was measured using a Siemens HFM 62B mass airflow sensor. The data acquisition system recorded the data from the analyzers and the sensors.

\subsubsection{Horiba, Ltd., 2003}

Horiba recently developed a system for on-road testing of vehicles called OBS-1000 [2829]. The system comprises vibration-proof gas analyzers, a laptop PC with data logging software, a data integration unit (DIU), accessory sensors, a power supply unit (PSU), a battery unit, a voltage monitor for batteries, and a tail-pipe attachment with a Pitot tube. The concentrations of gaseous emissions of $\mathrm{CO}, \mathrm{CO}_{2}$ and $\mathrm{HC}$ in vehicle exhaust are measured using a 
heated type NDIR analyzer, MEXA-1170 HNDIR, without water extraction. $\mathrm{NO}_{\mathrm{x}}$ concentration and air-fuel ratio are measured using a $\mathrm{ZrO}_{2}$-type analyzer, MEXA-720 $\mathrm{NO}_{\mathrm{x}}$. The data logging software on the PC can save vehicle parameters like vehicle velocity, engine speed and other external signals as well as the outputs of the gas analyzers and the accessory signals. The software can provide time-trend profiles and integrated values for both mass emission and fuel consumption.

\subsubsection{CE-CERT}

The CE-CERT constructed an emissions laboratory within a 53-foot container trailer to study the emissions from heavy-duty diesel vehicles under actual driving conditions [30 31 B2]. The laboratory was designed to replicate a traditional engine/chassis heavy-duty emissions laboratory configuration as closely as possible. The laboratory operates while in motion with the laboratory itself acting as the load for heavy-duty tractor to pull. Real-time emissions are measured using the on-board instrumentation provided. Also other instrumentation provided allows for post-processing to quantify gaseous and particulate emissions expressed in grams per mile or grams per horsepower-hour, over a testing cycle or for specific modal events.

\subsubsection{Analytical Engineering Inc.}

The Simple Portable On-Vehicle testing (SPOT) system developed at Analytical Engineering Inc. was basically used for investigation and modeling of off-road diesel emissions [33]. The system is capable of measuring $\mathrm{NO}_{\mathrm{x}}, \mathrm{O}_{2}$ (thus calculated $\mathrm{CO}_{2}$ ), total exhaust mass flow, relative humidity, ambient temperature, engine speed, fuel consumption, estimated brake specific $\mathrm{NO}_{x}$, GPS coordinates, barometric pressure and other engine parameters. The on-vehicle real-time brake-specific $\mathrm{NO}_{\mathrm{x}}$ emissions collected is currently used by USEPA to define the environmental impact of such emissions. For exhaust flow measurement a low-pressure area behind the nose cone is created, thus inducting outside air. The flowrate of clean outside air being inducted is measured with a hot-wire anemometer. It is reported that the induction zone is self-cleaning and no fouling occurs [34].

\subsubsection{National Center for Environmental Research}

The National Center for Environmental Research in collaboration with Massachusetts Institute of Technology and Aerodyne Inc. developed a remote sensing technique to measure emissions of motor vehicles under real-world conditions [35. The remote sensors used in the system are the Tunable Infrared Laser Differential Absorption Spectroscopy (TILDAS). A study was conducted on the application of TILDAS remote sensor for the measurement of emissions 
from heavy-duty diesel trucks. The remote sensing of $\mathrm{NO}_{2}$ emissions was demonstrated and good agreement was obtained comparing TILDAS measurement with other on-board measurement systems.

\subsubsection{Engine, Fuel and Emissions Engineering, Inc. 2002}

Ride-Along Vehicle Emission Measurement (RAVEM) system was developed based on the constant volume sampling principle 36/37]. The system is used to measure gaseous and particulate exhaust emissions. The RAVEM system resembles a conventional CVS system, with a dilution tunnel and the isokinetic sampling system for gaseous and particulate sampling.

\subsubsection{CleanAir Technologies International Inc., 2002}

CleanAir Technologies developed a Portable Emissions Measurement System (PEMS) capable of measuring emissions on a variety of vehicles and engines during real-world, in-use operation [22 38,39]. The features of the system are it is versatile, compact, lightweight and easy installed. Of the different configurations of PEMS, the Heavy-Duty unit is for electronically controlled diesel vehicles. The heavy-duty unit provides $\mathrm{CO}, \mathrm{CO}_{2}, \mathrm{O}_{2}, \mathrm{NO}_{\mathrm{x}}$, and $\mathrm{PM}$ values in total mass emissions in a second-by-second format. The system also includes a GPS system. The unit connects to the vehicle in three locations. Power is obtained from the cigarette lighter or directly from the battery using a clip-on power cord. Engine data are obtained from the vehicle's diagnostic link, and a sample probe is inserted into the tailpipe to obtain vehicle exhaust concentrations.

\subsubsection{NCSU, 2003}

North Carolina State University developed a study design procedure and demonstrated the use of portable onboard tailpipe emissions measurement systems for highway vehicles fueled by gasoline and E85 [40]8]. The instrument used for onboard data collection in the study was the OEM-2100 manufactured by Clean Air Technologies International, Inc. The description of the OEM-2100 is described in earlier section. The study performed aimed at onboard measurements that would aid in understanding the episodic nature of emissions, on-road emissions hotspots, and intravehicle variability in emissions and intervehicle variability in emissions. 


\subsection{Introduction}

This chapter discusses the equipments and procedures that were employed in this study. The chapter provides details of specifications of various sensors and analyzers that were incorporated into the Mobile Emissions Monitoring System (MEMS).

\subsection{Overview of MEMS}

The following sections discuss the various components of the MEMS system and their operation. Figure 3.1 shows the data acquisition and flow conditioning and analysis systems of MEMS.

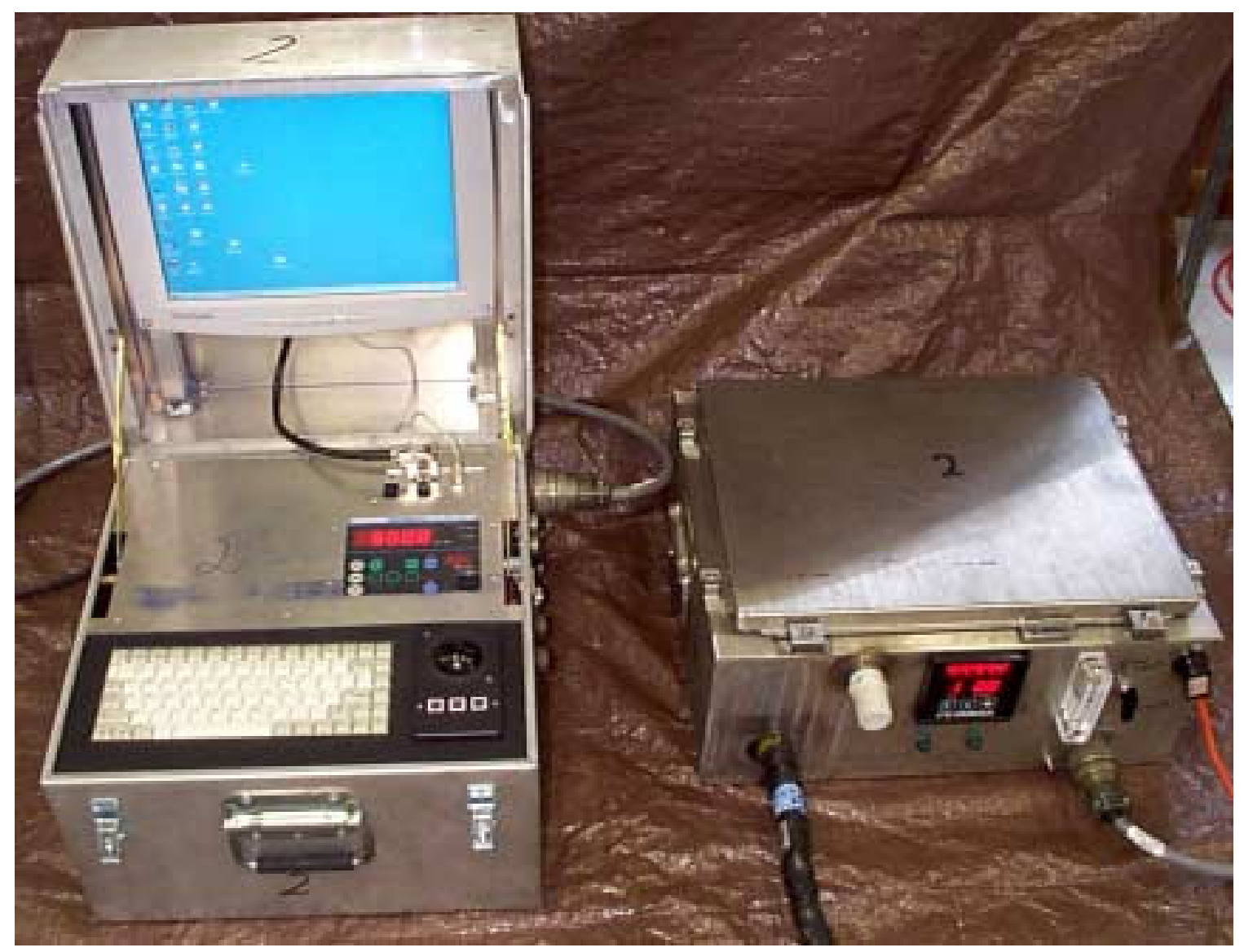

Figure 3.1 Data acquisition and sampling conditioning and analysis systems of MEMS.

Also discussed are the calibration procedures followed for the various transducers, sensors and the analyzers during the testing program. The major components of the MEMS system are the emissions sample conditioning and analysis box; exhaust flow rate measurement system and the data acquisition system. 


\subsubsection{Flow Rate Measurement System}

Exhaust mass flow rates were measured with a Dietrich Standard Annubar ${ }^{\mathrm{TM}}$ [41]. The Annubar is a multi-point averaging pitot tube that works on the principle of Bernoulli's theorem. Of the different configurations of the Annubar ${ }^{\mathrm{TM}}$, the regular threaded Pak-Lok assembly (Model $D C R+15 S$ or Model $D C R+25 S$ ) was used for the measurement process. Flow rate calculations required accurate measurements of differential and absolute pressures, and the exhaust gas temperature. Transducers that were used for the purposes are listed in detail in Section 3.2.7.1 Section 3.2.7.2 and Section 3.2.7.3 Figure 3.2 gives a representation of how the flow measurement system was fitted to the vehicle.

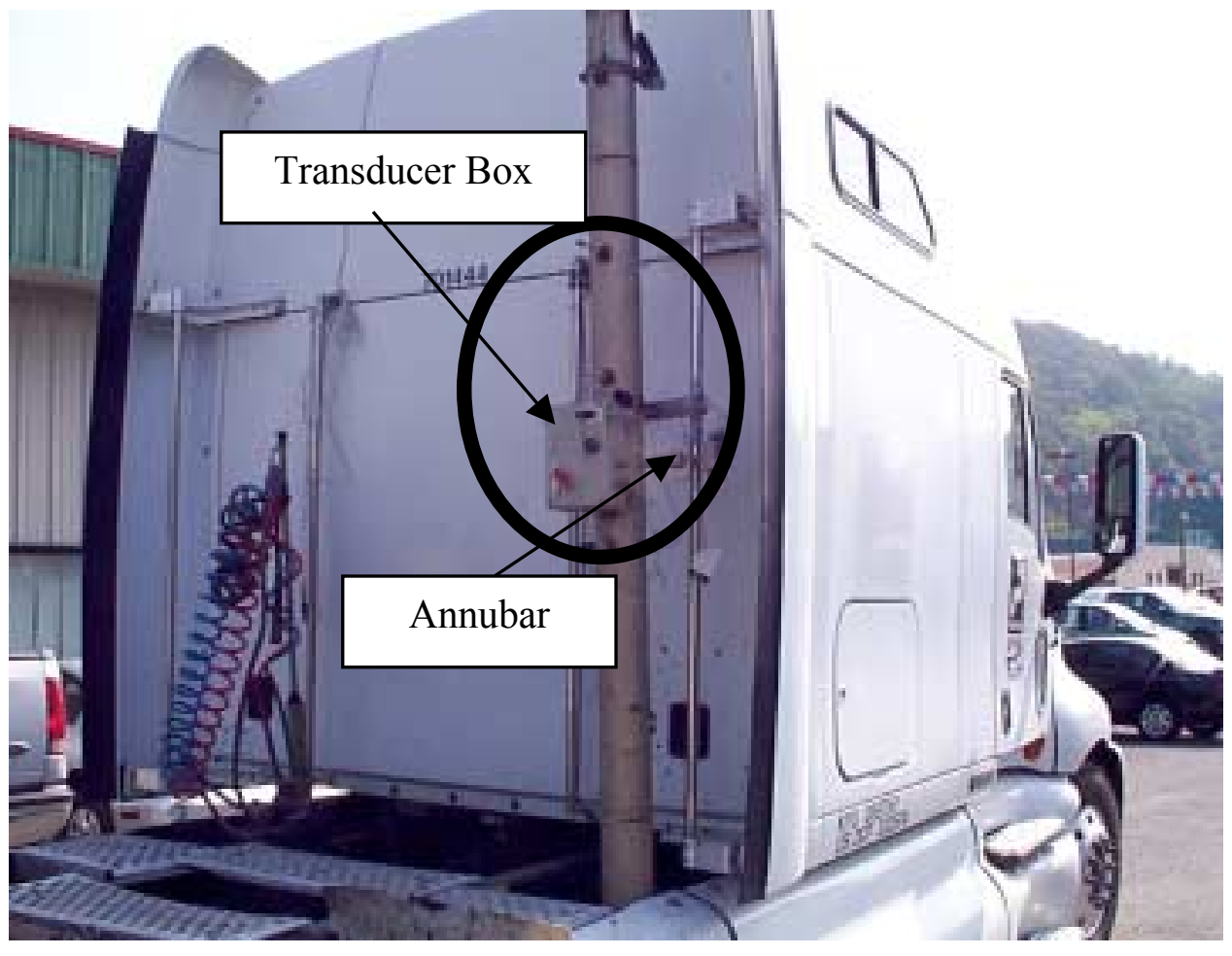

Figure 3.2 Representation of the exhaust flow measurement system fitted to the test vehicle.

\subsubsection{Gaseous Sampling and Sample Conditioning System}

The sampling probe that was placed in the exhaust stream complies with the regulations set by the 40 CFR, Part 89.412.96. The stainless probe, which has nine ports along its periphery, was placed spanwise across the flow so that representative sample is drawn from the exhaust stream. The other components of the exhaust sampling system included: heated Teflon line, heated filter and the pump. The heated Teflon sample line 0.25 " outer diameter was used to transfer the sample from the sample probe to the heated filter. Heating the sample prior to any 
drying device prevents condensation. The MEXA 120 Zirconium Oxide $\mathrm{NO}_{\mathrm{x}}$ sensor was placed downstream of the heated filter and upstream of the Air Dimensions Inc. Micro Dia-Vac sample pump. A $\mathrm{NO}_{2}$ to $\mathrm{NO}$ converter was incorporated with the $\mathrm{NO}_{\mathrm{x}}$ sensor manifold to minimize space requirements. Downstream of the pump, a custom-designed compact Peltier effect gas chiller removed moisture from the sample stream, and provided an outlet dew point of approximately $40^{\circ} \mathrm{F}$. A differential pressure regulator, in conjunction with needle valves, controlled flow rate to the $\mathrm{CO}_{2}$ analyzer and the electrochemical NO sensor to 3.0 LPM and 0.5 LPM respectively. A schematic of the sampling system is shown in Figure 3.3 [ ] $]$.

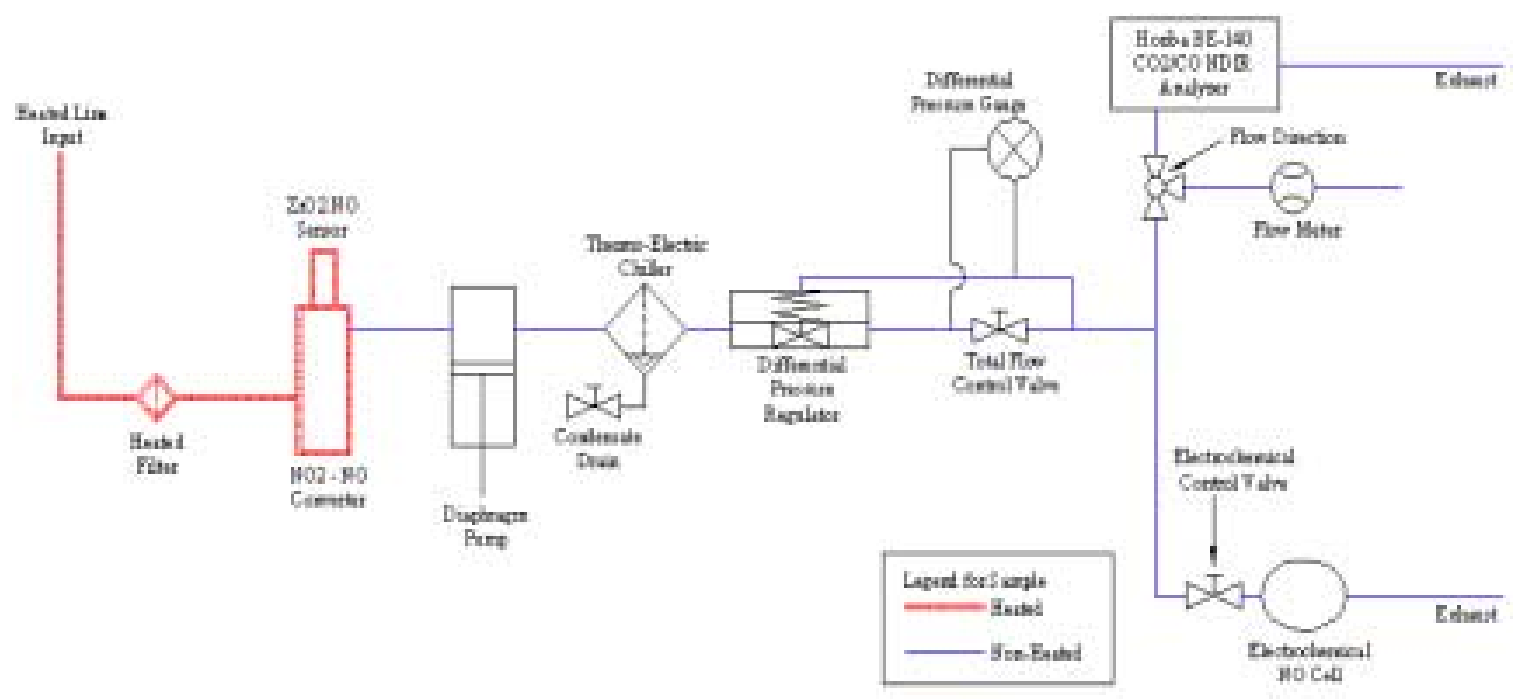

Figure 3.3 Schematic of the MEMS sampling system. [3]

\subsubsection{Peltier Coolers}

Humidity in the exhaust sample was removed in order to quantify the emissions measurements as "dry" measurements. This was achieved by chilling the sample to lower the dew point temperature, and then condensing the moisture in the sample. The gas chiller consisted of a thermo-electric chiller (TEC), which is solid-state heat pump that employs the Peltier effect. During operation, DC current flows through the TEC causing heat to be transferred from one side of the TEC to the other, creating a cold and hot side. The thermal energy is transferred from the hot side to a heat sink, which dissipates the heat to the environment. This dissipation of thermal energy present in the sample helps in lowering the dew point temperature and aids in the condensation. 


\subsubsection{Engine Speed and Torque Measurement}

The ECU broadcast was used to record the various engine and vehicle parameters including, engine speed and also vehicle speed. The vehicle speed broadcasted can be used to infer the distance traveled, which was determined with the GPS in the MEMS. The ECU also broadcasts engine load on a percent basis. The engine speed was broadcasted at $10 \mathrm{~Hz}$ with a resolution of 0.25 -rpm resolution and the engine percent load was broadcasted at $10 \mathrm{~Hz}$ with a $0.5 \%$ resolution 10 . The broadcast ECU load was derived from fuel consumption, and that was inferred from fuel injector flow rate information. Therefore, ECU engine load is a prediction of total work performed by burning a given quantity of fuel. The ECU load estimation included frictional loads inherent to the mechanical assembly and accessory loads, which had a negative effect in terms of actual work available for use by the vehicle. In some cases the ECU load estimates exceeded $100 \%$, but that was that is largely due to the manufacturer's desire to utilize all of the system resolution. The following procedure was followed in estimating the torque output, from the broadcast \%load value. The ECU load for a given operating point ( $\left.E C U_{\%}^{r p m}\right)$ was normalized using the associated ECU load for that engine speed that was obtained from the curbside no-load idle curve $\left(E C U_{\text {noload }}^{\text {rpm }}\right)$ and the measured dynamometer engine lug curve $\left(E C U_{\% \max }^{r p m}\right)[10$.

$$
T^{r p m}(t)=\left(\frac{E C U_{\%}^{r p m}-E C U_{\text {noload }}^{r p m}}{E C U_{\% \max }^{r p m}-E C U_{\text {noload }}^{r p m}}\right) * T_{\max }^{r p m}
$$

\subsubsection{Data Acquisition, Reduction and Archival Subsystem}

The data acquisition system (DAS) used by MEMS was designed to withstand the vibrations encountered during on-road testing. The DAS was so configured that it can adapt to a wide array of test vehicles and variety of signals.

The DAS was controlled by an Advantech PCM-9570/S single board computer (SBC) running at $850 \mathrm{MHz}$ and supported by a $256 \mathrm{MB}$ RAM 10]. The SBS was configured with PC104 capabilities, which allowed the system to be more modular, and reduced the overall size of the system. The signal conditioning of analog signals were done using a SC-2345 National Instruments signal conditioning system. A National Instruments PCMCIA E-Series DAQ Card6062 read the conditioned signals. The DAQ card can have up to 16 analog input channels and 12 bits resolution. The ECU broadcast information was communicated to the SBC through the use of a Dearborn Group (DG) DPAIII/PC104 Protocol adapter. For some test vehicles, the ECU 
interface was also alternatively provided by means of a DPA II or DPAIII Serial Port Protocol adapter. These components were integrated and installed into a custom-fabricated aluminum enclosure. The enclosure also housed the control panel for the Horiba MEXA 120, as well as the keyboard, mouse, and the front panel LCD monitor.

\subsubsection{Global Positioning Sensor}

A GPS was used as a redundant method for measuring vehicle speed along with the broadcasted ECU speed. A Garmin GPS35 was mounted on each vehicle as part of the MEMS equipments [42].

\subsubsection{Power Supply}

The vehicle-mounted generator set or trailer-mounted, dependant upon the test vehicle platform, fulfilled the power requirements of the current MEMS design. Surge protectors were used for the DAS.

\subsubsection{Transducers}

Various transducers were used as part of flow measurement system of MEMS. It includes transducers for the measurement of pressure, differential pressure, temperature and relative humidity.

\subsubsection{Absolute Pressure Transducer}

The Omega PX-213 was the sensor used for the purpose of absolute pressure measurement for the Annubar flow measurement [43]. The specifications of this transducer are listed in Table 3-1.

Table 3-1 Absolute pressure transducer specifications.

\begin{tabular}{|c|c|}
\hline \multicolumn{2}{|c|}{ General specifications } \\
\hline \hline Ranges & $0-15$ psi, 0-30 psi \\
\hline \hline Accuracy & $\begin{array}{c}+/-0.25 \% \text { FS, includes non-linearity, } \\
\text { hysteresis and non-repeatability }\end{array}$ \\
\hline \hline Response Time & $1 \mathrm{msec}$ \\
\hline \hline Proof Pressure & $150 \%$ Full Scale \\
\hline \hline Pressure Ports & $1 / 4$ '-18 NPT \\
\hline \hline Operating Temperature & -4 to $185^{\circ} \mathrm{F}$ \\
\hline \hline Temperature Error & $+/-0.017 \% \mathrm{FS} /{ }^{\circ} \mathrm{F}$ \\
\hline \hline
\end{tabular}




\subsubsection{Differential Pressure Transducer}

The Validyne Model P55D differential pressure transducer was selected for the purpose of Annubar flow measurement 444. The variable reluctance sensing technology allows the P55D to be used in a wide variety of low-pressure measurements. It also gives a fast dynamic response, high resistance to vibration and superior signal stability through temperature changes. The specifications of the P55D transducer are given in Table 3-2.

Table 3-2 Differential pressure transducer specifications.

\begin{tabular}{|c|c|}
\hline \multicolumn{2}{|r|}{ General specifications } \\
\hline Ranges & $0-8 ", 0-10 ", 0-22 " \mathrm{H}_{2} \mathrm{O}$ \\
\hline Accuracy & $\begin{array}{l}+/-0.25 \% \mathrm{FS} \text {, includes non-linearity, hysteresis } \\
\text { and non-repeatability }\end{array}$ \\
\hline Overpressure & $\begin{array}{l}200 \% \text { FS up to } 4000 \text { psi maximum with less than } \\
0.5 \% \text { FS output shift }\end{array}$ \\
\hline Line Pressure & $\begin{array}{l}3200 \text { psig maximum, with zero shift less than } \\
1 \% / \mathrm{Kpsi}\end{array}$ \\
\hline Pressure Ports & $\begin{array}{l}\text { 1/8" female NPT with 8-32 Bleed Screw \& } \\
\text { Gasket, STD }\end{array}$ \\
\hline \multicolumn{2}{|c|}{ Environmental Specifications } \\
\hline Operating Temperature & -65 to $+250^{\circ} \mathrm{F}$ \\
\hline Compensated Temperature & $\begin{array}{l}0 \text { to }+160^{\circ} \mathrm{F} \text { (STD) } \\
-65 \text { to }+250^{\circ} \mathrm{F} \text { (Extended) }\end{array}$ \\
\hline Temperature Error & $\begin{array}{l}+/-0.5 \% \text { FS }- \text { STD Range } \\
+/-0.75 \% \text { FS - Extended Range }\end{array}$ \\
\hline
\end{tabular}

\subsubsection{Relative Humidity Transducer}

The Omega model HX92-A was used for the purpose of monitoring continuous ambient relative humidity and temperature [45]. A thin-film polymer capacitor senses relative humidity. The transmitter output is linearized and temperature compensated. A stainless steel mesh-wire filter that is easily removable for cleaning protects the sensor. The specifications of this transducer are provided in Table 3-3. 
Table 3-3 Relative humidity transducer specifications

\begin{tabular}{|c|c|}
\hline Input Voltage Range & $24 \mathrm{Vdc}$ \\
\hline Measuring Range & 3 to $95 \%$ \\
\hline Temperature & -4 to $167^{\circ} \mathrm{F}$ \\
\hline \multirow{2}{*}{ Accuracy } & $+/-2.5 \%$ RH from 20 to $80 \%$ RH \\
\hline & $+/-3.1 \%$ RH below 20 and above $80 \% \mathrm{RH}$ \\
\hline Output Voltage & 0 to $1 \mathrm{Vdc}$ for 0 to $100 \% \mathrm{RH}$ \\
\hline RH Temperature Compensation & -4 to $167^{\circ} \mathrm{F}$ \\
\hline \multirow{2}{*}{$\begin{array}{l}\text { RH Time Constant ( } 90 \% \text { response } \\
\left.\text { at } 25^{\circ} \mathrm{C} \text {, in moving air at } 1 \mathrm{~m} / \mathrm{s}\right)\end{array}$} & $>10$ seconds, 10 to $90 \% \mathrm{RH}$ \\
\hline & $>15$ seconds, 90 to $10 \% \mathrm{RH}$ \\
\hline Repeatability & $+/-1 \% \mathrm{RH}, 0.5^{\circ} \mathrm{F}$ \\
\hline
\end{tabular}

\subsection{Exhaust Gas Analyzers}

For Phase III of the Consent Decrees in-use testing program, the oxides of nitrogen $\left(\mathrm{NO}_{\mathrm{x}}\right)$ and carbon dioxide were identified as gaseous emissions to be measured. Analyzers used with the MEMS system were decided at the end of Phase II of the program. Table 3-4 gives the list of analyzers used, their operation type, the detection device used and their source.

Table 3-4 Analyzers used

\begin{tabular}{|c|c|c|c||}
\hline Source & $\begin{array}{c}\text { Horiba Instruments, } \\
\text { Inc. }\end{array}$ & $\begin{array}{c}\text { Horiba Instruments, } \\
\text { Inc. }\end{array}$ & Sensors Inc. \\
\hline Model & BE-140 AD & MEXA-120 & AMB-II \\
\hline Operation Type & NDIR & $\begin{array}{c}\text { Zirconium oxide } \\
\left(\mathrm{ZrO}_{2}\right)\end{array}$ & Electrochemical \\
\hline Detection Device & Solid State Optical & $\begin{array}{c}\text { Non-Sampling } \\
\mathrm{ZrO}_{2}\end{array}$ & Solid State optical \\
\hline Gases Measured & $\mathrm{CO}_{2}$ & $\mathrm{NO}_{\mathrm{x}}$ & NO \\
\hline
\end{tabular}

\subsubsection{Carbon Dioxide Analyzer}

The BE-140 AD five gas analyzer was used for the measurement of carbon dioxide. The features and the operating principle of the analyzer are mention in the following sections.

\subsubsection{General Features of BE-140 AD}

Based on the principle of non-dispersive infrared analysis, BE-140 AD includes:

1. Broad-band infrared light source 


\section{Chopper motor}

3. Four detectors -- one reference and one each for $\mathrm{CO}, \mathrm{CO}_{2}$, and $\mathrm{HC}$.

\subsubsection{Operating Principle BE-140 AD}

Light emission from the broad-band infrared light source is passed through the sample cell containing the gases to be analyzed. The gases absorb some of the intensity of the light beam passing through the sample. The attenuated beam modulated by the chopper motor sequentially passes into each of the four detectors. Each detector has a narrow band-pass filter, which isolates a spectral region specific to the corresponding gas $\left(\mathrm{CO}, \mathrm{CO}_{2}\right.$, or $\left.\mathrm{HC}\right)$. The reference detector is insensitive to all three gases. When a non-absorbing gas (like nitrogen) flows through the sample cell, the same amount of light emission reaches the reference and sample detectors. When absorbing gases $\left(\mathrm{CO}, \mathrm{HC}, \mathrm{CO}_{2}\right)$ flow through the sample cell, less intensity reaches the sample detectors than the reference detector. An electrical signal is produced in proportion to the changes in energy absorption. The difference between sample and reference signals represents concentration of the respective components, and an output is generated.

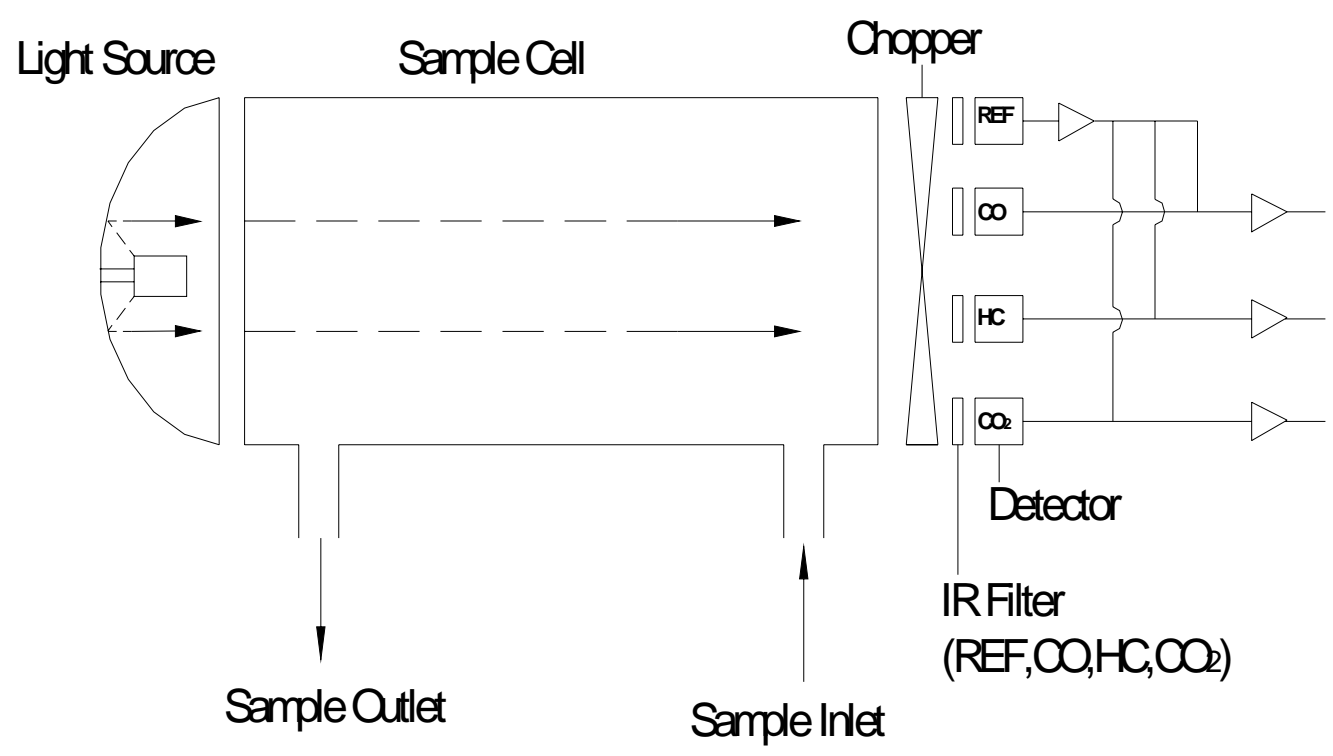

Figure 3.4 Schematic of the operating principle of the BE-140AD analyzer. 


\subsubsection{Oxides of Nitrogen Analyzer}

Two analyzers were used for the purpose of measurement of the oxides of nitrogen. One was the MEXA-120 $\mathrm{NO}_{\mathrm{x}}$ analyzer from Horiba Inc., and another one was the $\mathrm{EC}_{\mathrm{NO}}$ from Sensors Inc. The general features and the operating principle are clearly described below.

\subsubsection{General Features of MEXA $120 \mathrm{NO}_{x}$}

The model MEXA-120 $\mathrm{NO}_{\mathrm{x}}$ is a portable analyzer for measuring the $\mathrm{NO}_{\mathrm{x}}$ concentrations in exhaust gas streams with its unique sensor made of zirconium oxide ceramics. The main features include:

- Light weight, compact size

- In-situ detection (non-sampling analyzer)

- Fast time response $(\mathrm{T} 90<1 \mathrm{sec})$

- Flexible power configuration (12 to $24 \mathrm{~V} \mathrm{DC}, 100$ to $240 \mathrm{~V}$ AC available)

Table 3-5 Specifications of MEXA $120 \mathrm{NO}_{\mathrm{x}}$ analyzer

\begin{tabular}{|c|c|}
\hline Ranges & $0-5000 \mathrm{ppm}$ \\
\hline Response Time & $\mathrm{T}_{90}$ within $1 \mathrm{~s}$ \\
\hline Accuracy & $\pm 30 \mathrm{ppm}$ or $\pm 3 \%$ of reading, whichever is larger \\
\hline Warm-up Time & 3 minutes \\
\hline Acceptable Vibration & For sensor: $0-294 \mathrm{~m} / \mathrm{s}^{2} \quad 0-30 \mathrm{G}$ \\
\hline Calibration Gas & Calibration gas: $\mathrm{NO} 50-5000$ ppm with $\mathrm{H}_{2} \mathrm{O}$ \\
\hline Sample Gas Conditions & Measurement gas temperature: -7 to $800^{\circ} \mathrm{C}$ \\
\hline Ambient Conditions & For main unit: 5 to $45^{\circ} \mathrm{C}$; less than $80 \%$ R.H. \\
\hline Dimensions and Weight & W $\times$ H x D: $5.9 \times 6.0 \times 11.3$ in, $6.6 \mathrm{lbs}$ \\
\hline Power & 85 to $264 \mathrm{~V} \mathrm{AC}, 12$ to $24 \mathrm{~V} \mathrm{DC}, 70 \mathrm{VA}$ \\
\hline Outputs & Analog: 0-1 V DC or 0-5 V DC, Digital: RS-232C \\
\hline Accessories & Unit includes: Cable for sensor $(10 \mathrm{~m})$ \\
\hline
\end{tabular}




\subsubsection{Operating Principle of MEXA $120 \mathrm{NO}_{\mathrm{x}}$}

Measured gas flows into the first internal cavity through the first diffusion path. Oxygen concentration inside the first internal cavity is kept low, by pumping out oxygen from the cavity. Then the measured gas diffuses into the second internal cavity. In the second internal cavity, oxygen concentration is kept at a lower value and $\mathrm{NO}$ is split into nitrogen and oxygen. Oxygen generated by this reaction is pumped out and NO concentration is calculated by measuring the pumping current $[47[48,49]$.

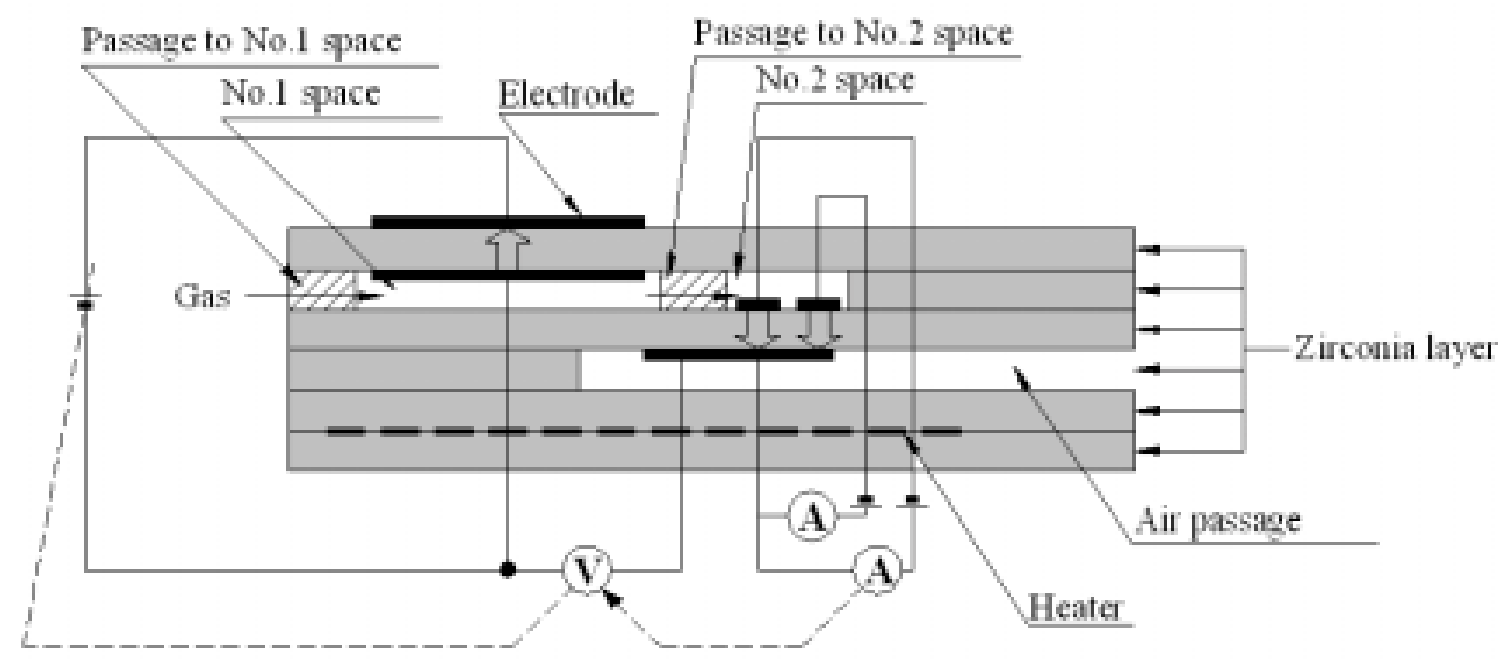

Figure 3.5 Schematic of the operating principle of $\mathrm{NO}_{\mathrm{x}}$ sensor

\subsubsection{General Features of Electrochemical $\mathrm{NO}_{x}$}

An Electrochemical $\mathrm{NO}_{\mathrm{x}}$ sensor was used for collecting redundant $\mathrm{NO}_{\mathrm{x}}$ measurements. The electro chemical sensor used in the MEMS meets the BAR 97 specifications.

The system comprises a transducer and a manifold. In addition to the electrochemical sensor, the transducer contains a small lithium battery and a biasing circuit to assure that the sensor is ready to work upon installation. The manifold is designed to protect the transducer from the effects of vibration and shock. The manifold also contains pre-amp electronics that amplify and temperature compensates the transducer signal. 
Table 3-6 Specifications of electrochemical $\mathrm{NO}_{\mathrm{x}}$ analyzer

\begin{tabular}{||l||c||}
\hline \hline Ranges & $0-5 \mathrm{~K}$ ppm (measured as NO) \\
\hline \hline \hline Response Time & $T_{90}$ within $12 \mathrm{~s}$ \\
\hline \hline Accuracy & $\pm 25 \mathrm{ppm}$ (absolute or $4 \%$ of reading) \\
\hline \hline \hline Ambient Conditions & $35^{\circ} \mathrm{F}$ to $115^{\circ} \mathrm{F}$ \\
\hline \hline Zero Drift & $\pm 5 \mathrm{ppm}$ in 24 hours \\
\hline \hline Span Drift & $\pm 2 \%$ of reading over 8 hours \\
\hline \hline Repeatability & $\pm 2 \%$ of reading \\
\hline \hline Noise & Less than 16 ppm (below $1000 \mathrm{ppm})$ \\
\hline \hline
\end{tabular}

\subsubsection{Operating Principle of Electrochemical $\mathrm{NO}_{\mathrm{x}}$}

An electrochemical cell consists of two or more electrodes separated by an electrolyte. For a cell with two electrodes, one of the electrodes needs to be porous so that the gas can pass through it after diffusing through the membrane. A resistor is connected between the two electrodes and voltage drop across the resistor is converted to gas concentration. This is in accordance to Fick's law of diffusion, where if the rate of diffusion is controlled via a membrane, the current flowing through the resistor and therefore, the voltage drop across the resistor is proportional to the concentration of candidate gas [47/48,49].

\subsection{Component Calibrations}

Two Laminar Flow Elements (LFE) manufactured by Meriam Instruments were used for quantification of MEMS exhaust mass flow rate measurement errors. Although Dietrich Standard provided calibration constants with the Annubar ${ }^{\mathrm{TM}}$ devices, these constants were not unique to each unit, but universally supplied for all units of a given size. Conversely, Meriam Instruments supplied calibration equations and coefficients that are unique to each LFE unit, and provide certification of the LFE's calibration against a NIST traceable subsonic venturi. Annubar ${ }^{\mathrm{TM}}$. devices were qualified using an LFE in a series arrangement. A filtered air source was then introduced through both flow rate measurement devices. Differential and absolute pressure measurements for both the Annubar ${ }^{\mathrm{TM}}$ and LFE were recorded with a Dresser Heise ${ }^{\mathrm{TM}}$ model PTE-1 handheld pressure calibrator, accurate to within $\pm 0.05 \%$ F.S. Test data were logged to a 
laptop computer via the built-in serial port and then post-processed. Temperature measurements were recorded using J-type thermocouples and Fluke thermocouple readers. The test results substantiated the accuracy figures provided by Dietrich Standard.

The analyzers were calibrated with a Horiba SGD-710C gas divider using gas bottles of know concentrations. The concentrations of gases used were dependent on the maximum concentration in the exhaust of the engine being tested to limit the uncertainty error from the analyzer. Also the calibration gases used were $\pm 1 \%$ accurate. A three-way valve was placed at the entrance of the heated sample line, which allowed the calibration line to be connected to the analyzer without removing the heated line. The calibration procedure was performed before each test, which included a zero and a span for the Horiba BE140 and a three-point calibration for the Horiba MEXA 120 and the electrochemical NO cell.

Multi-point calibration curves were developed for the absolute and differential pressure transducers using a Heise ${ }^{\mathrm{TM}}$ PTE-1 pressure calibrator. Barometric pressure readings (taken prior to each test) were used to re-set the calibration curve intercepts of the absolute pressure in order to account for sensor drift. Similarly, pre-test calibration also included zeroing the differential pressure transducer.

The relative humidity sensor was calibrated using the RH calibration kit. The procedure used is based on using selected salt solutions to produce a known RH. The method is based on the ASTM standard E104-85 "Standard Practice For Maintaining Constant Relative Humidity by Means of Aqueous Solutions" 46 . 


\section{DESIGN OF NO CONVERTER $_{\mathrm{x}}$}

\subsection{Introduction}

The external $\mathrm{NO}_{\mathrm{x}}$ converter $\left(\mathrm{NO}_{2}\right.$ to $\left.\mathrm{NO}\right)$ was used in the MEMS to condition the sample stream upstream of the $\mathrm{NO}_{\mathrm{x}}$ analyzer. In catalyzed diesel particulate filter (DPF) equipped diesel engine exhaust, $\mathrm{NO}_{2}$ forms a relatively large portion of $\mathrm{NO}_{\mathrm{x}}$. In diesel engines without retrofits, $\mathrm{NO}_{2}$ may constitute $3 \%$ to $10 \%$ of total $\mathrm{NO}_{\mathrm{x}}$ and it may be higher when air/fuel ratios are higher than 60. It should be noted that currently exhaust gas analyzers and the MEXA-120 $\mathrm{NO}_{\mathrm{x}}$ analyzer which is used in the MEMS has a varying response to $\mathrm{NO}_{2}$ depending on the $\mathrm{NO}_{2}$ concentration 49,50]. Hence, there arises a need to have a $\mathrm{NO}_{\mathrm{x}}$ converter to obtain accurate measurements of the total oxides of nitrogen $\left(\mathrm{NO}_{\mathrm{x}}\right)$. Various configurations of the sampling system were tested to obtain highest conversion efficiency for the converter.

\subsection{Design of the $\mathrm{NO}_{\mathrm{x}}$ converter}

Various designs were considered for the $\mathrm{NO}_{\mathrm{x}}$ converter. Some of the problems that were encountered in the design of the converter were maintaining a high flow rate through the converter, proper heating of the catalyst and positioning of the $\mathrm{NO}_{\mathrm{x}}$ sensor. The final design of he converter that was used in MEMS is shown in Figure 4.1 below.

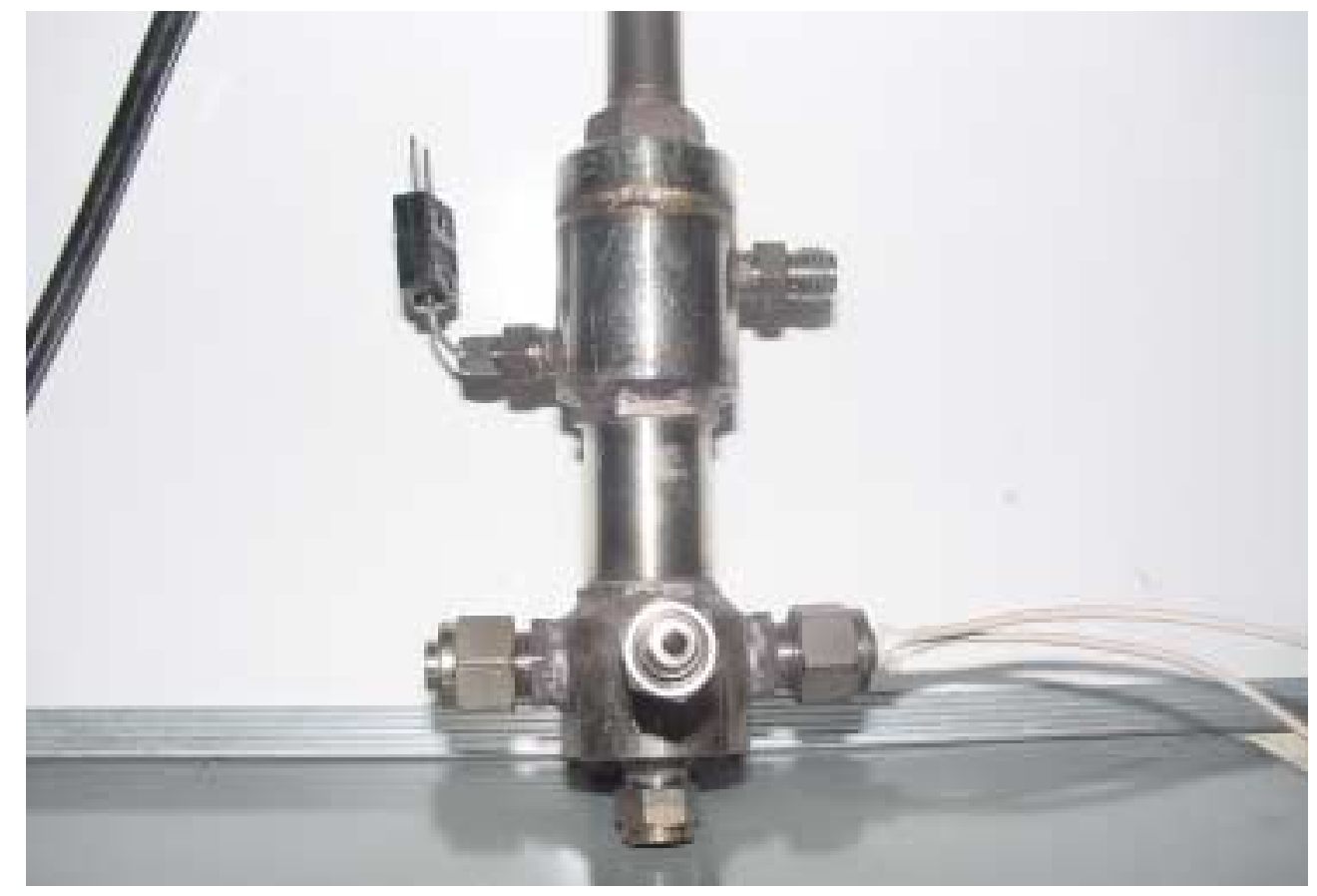

Figure 4.1 Picture of $\mathrm{NO}_{\mathrm{x}}$ converter 


\subsection{Need for a Converter Catalyst}

For a reaction to take place there have to be collisions occurring between reactant molecules or atoms. Collisions only result in a reaction if the particles collide with enough energy to get the reaction started. This minimum energy required is called the activation energy for the reaction. A catalyst is a substance that speeds up a reaction, by reducing the activation energy and remains chemically unchanged at the end of the reaction. Converter catalysts are transition metals and their oxides suspended on a matrix of ceramic material designed to offer the exhaust gases an enormous surface area as they pass through. The metal/metal oxide catalysts lower the activation energy necessary to get to the transition state and increase the rate of the reverse reaction.

\subsection{Effect of Temperature on Chemical Reactions}

Rate of reaction are directly proportional to the reaction temperature. As a rough approximation, for many reactions that take place at room temperature, the rate of reaction doubles for every $10^{\circ} \mathrm{C}$ rises in temperature. The spontaneity of a chemical reaction at any given temperature can be determined using the concept of Gibbs free energy change. The definition of the Gibbs free energy is 51,52$]$

$$
G=H-T^{*} S
$$

where, $\mathrm{G}$ is the free energy, $\mathrm{H}$ is the enthalpy and $\mathrm{S}$ is the entropy. The change in Gibbs free energy for a reaction where the temperature does not change is given by the "Gibbs-Helmholtz equation"

$$
\Delta G=\Delta H-T * \Delta S
$$

where, $\Delta H$ is the change in enthalpy and $\Delta S$ is the change in entropy. The two values are determined from the tables of standard entropy and enthalpy. The sign of $\Delta G$ determines the spontaneity of the reaction,

$\Delta G<0$ : the reaction is spontaneous

$\Delta G>0$ : the reaction is not spontaneous

$\Delta G=0$ : the reaction is at equilibrium.

The $\mathrm{NO}_{2}$ reduction reaction is represented by

$$
2 \mathrm{NO}_{2} \rightarrow 2 \mathrm{NO}+\mathrm{O}_{2}
$$


The change in Gibbs free energy was calculated for a few temperatures with the temperature range of operation of the converter. For the temperatures chosen the Gibbs energy of change was determined. The Gibbs free energy at $300^{\circ} \mathrm{F}, 325^{\circ} \mathrm{F}$ and $350^{\circ} \mathrm{F}$ was determined as follows,

$$
\begin{aligned}
& \Delta H=\left(2 * \Delta H_{\mathrm{NO}}^{0}+1 * \Delta H_{\mathrm{O}_{2}}^{0}\right)-\left(2 * \Delta H_{\mathrm{NO}_{2}}^{0}\right) \\
& \Delta H=(2 * 22.58+1 * 0)-(2 *-9.03) \\
& \Delta H=27.10 \mathrm{kcal} / \mathrm{mol} \\
& \Delta S=\left(2 * \Delta S_{\mathrm{NO}}^{0}+1 * \Delta S_{\mathrm{O}_{2}}^{0}\right)-\left(2 * \Delta S_{\mathrm{NO}_{2}}^{0}\right) \\
& \Delta S=(2 * 2.50+1 * 2.51)-(2 * 3.33) \\
& \Delta S=0.85 * 10^{-3} \mathrm{kcal} / \mathrm{mol} . \mathrm{K}
\end{aligned}
$$

Combining the two of them into $\Delta G$

$$
\Delta G=\Delta H-T \Delta S
$$$$
\Delta G=27.1 \mathrm{kcal} / \mathrm{mol}-422 \mathrm{~K}\left(0.85 * 10^{-3} \mathrm{kcal} / \mathrm{mol} . \mathrm{K}\right)
$$$$
\Delta G=26.74 \mathrm{kcal} / \mathrm{mol}
$$

Similarly, $\Delta G$ at $325^{\circ} \mathrm{F}$ and $350^{\circ} \mathrm{F}$ was calculated to be $26.65 \mathrm{kcal} / \mathrm{mol}$ and 26.59 $\mathrm{kcal} / \mathrm{mol}$. Above calculations of Gibbs's free energy values show that the $\mathrm{NO}_{2}$ reduction is not a spontaneous reaction within temperature ranges under investigation. Hence, there arises a need

for using a catalyst for the conversion process, which would provide a new reaction pathway in which lower activation energy is offered.

\subsection{Catalyst for the $\mathrm{NO}_{\mathrm{x}}$ converter}

There are a number of commercially available catalysts that are used for the conversion of $\mathrm{NO}_{2}$ to NO. Efficiency tests were done on some of the catalysts using the MEMS system. Finally, the Horiba $\mathrm{NO}_{\mathrm{x}}(\mathrm{Mo} / \mathrm{Vitreous}$ Carbon) catalyst 53 was chosen for use in the converter. Table 4-1 lists two of the catalysts that were tested and their sources. 
Table 4-1 Catalysts used for the converter testing

\begin{tabular}{|c||c||c||}
\hline Catalyst & Name & Source \\
\hline \hline $\mathrm{A}$ & $\begin{array}{c}\text { Horiba Catalyst } \\
(\text { Mo/Vitreous Carbon })\end{array}$ & Horiba Inc. \\
\hline \hline $\mathrm{B}$ & Vitreous Carbon & Rosemount Analytical Inc. \\
\hline
\end{tabular}

\subsection{Effect of the Sampling System Configuration on the Conversion efficiency of the $\mathrm{NO}_{\mathrm{x}}$ Converter}

Experiments were performed with the converter to evaluate the effect of the sampling system configuration on the conversion efficiency. This was an effort to determine the optimum operating conditions for the maximum converter efficiency during in-use testing.

The first set of tests was performed to evaluate the effect of varying sampling line temperature on conversion efficiency. The sample flow rate through each catalyst was kept constant (fixed sampling residence time). Tests were repeated on both the catalysts. $\mathrm{An}^{\mathrm{NO}_{2}}$ bottle of 600ppm concentration was used for testing purposes. The MEXA 120 analyzer was calibrated using NO with a 1000ppm concentration.

For the next set of tests the sample line temperatures were maintained constant, and the flow rate was varied. The following Table 4-2 gives the test matrix that was followed in performing the efficiency tests.

Table 4-2 Sampling conditions for the $\mathrm{NO}_{\mathrm{x}}$ converter

\begin{tabular}{|c||c|c|}
\hline Catalyst & Temperature $\left({ }^{\circ} \mathbf{F}\right)$ & Flow rate (lpm) \\
\hline \hline $\mathrm{A}$ & 300 & 3.0 \\
\hline \hline $\mathrm{A}$ & 325 & 3.0 \\
\hline \hline $\mathrm{A}$ & 350 & 3.0 \\
\hline \hline $\mathrm{B}$ & 300 & 3.0 \\
\hline \hline $\mathrm{B}$ & 325 & 3.0 \\
\hline \hline $\mathrm{B}$ & 350 & 3.0 \\
\hline \hline $\mathrm{A}$ & 300 & 3.5 \\
\hline \hline $\mathrm{A}$ & 325 & 3.5 \\
\hline \hline $\mathrm{A}$ & 350 & 3.5 \\
\hline \hline $\mathrm{B}$ & 300 & 3.5 \\
\hline \hline $\mathrm{B}$ & 325 & 3.5 \\
\hline $\mathrm{B}$ & 350 & 3.5 \\
\hline
\end{tabular}




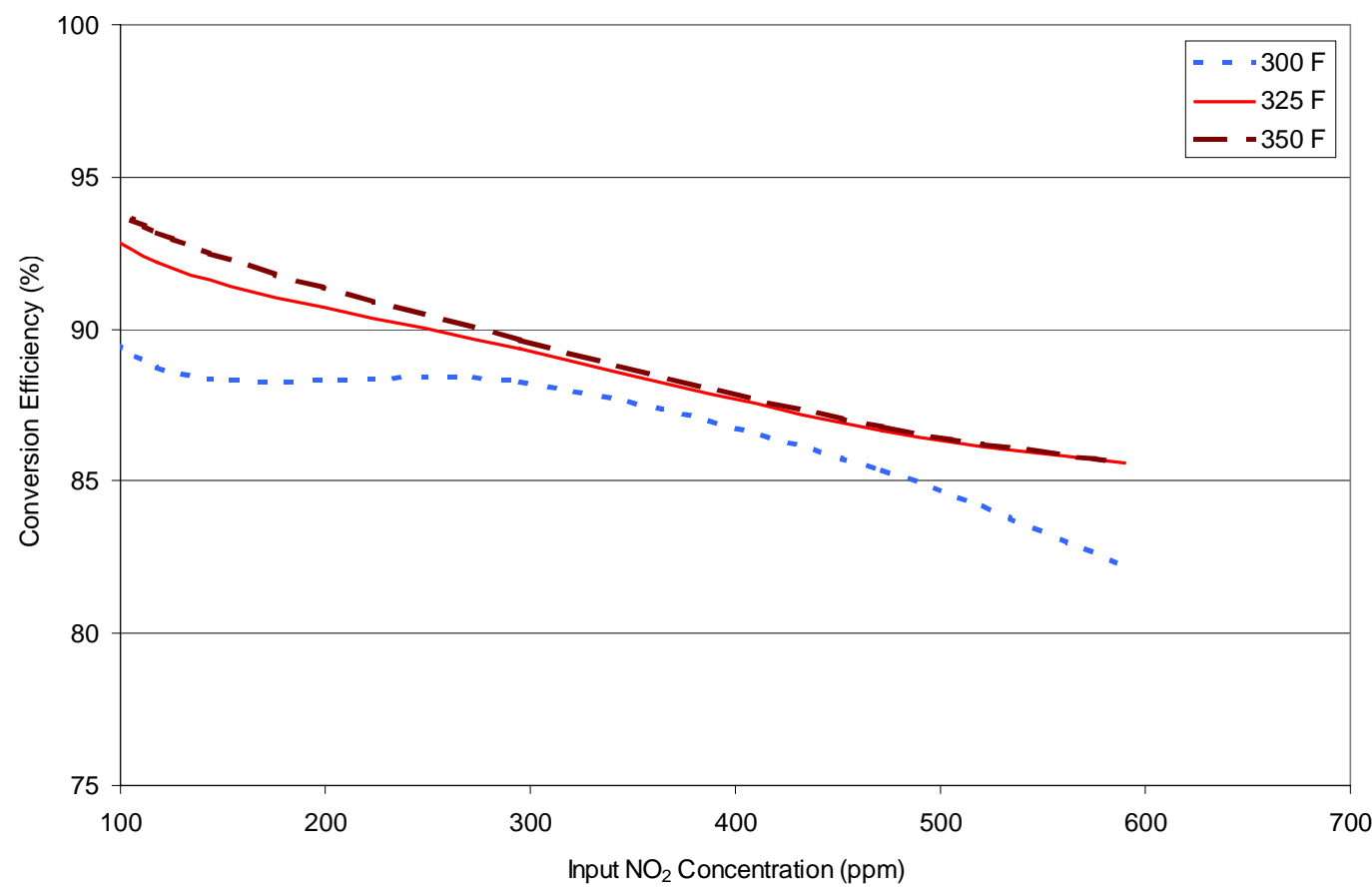

Figure 4.2 Comparison of the $\mathrm{NO}_{\mathrm{x}}$ converter efficiency with a flow rate of $3.0 \mathrm{lpm}$ at temperatures of $300^{\circ} \mathrm{F}, 325^{\circ} \mathrm{F}$ and $350^{\circ} \mathrm{F}$ using Horiba catalyst.

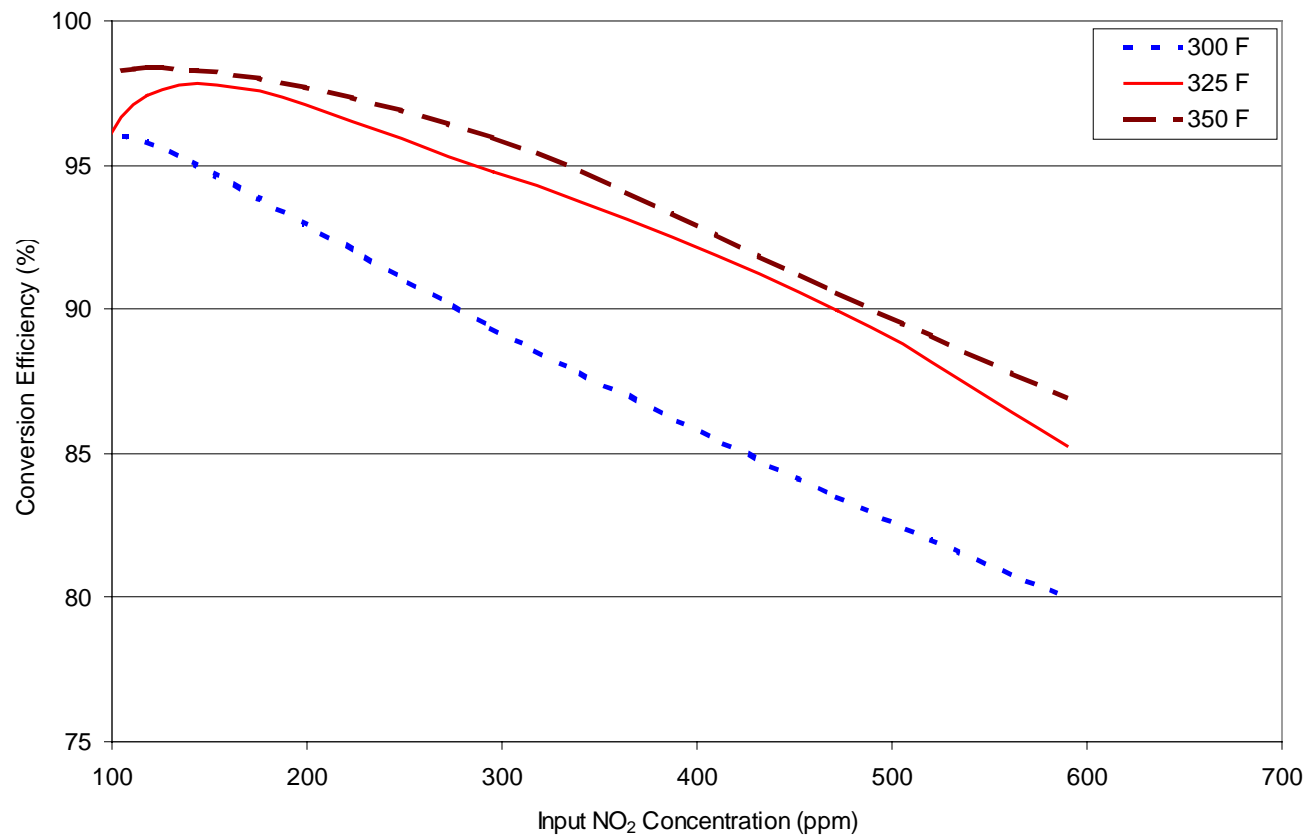

Figure 4.3 Comparison of the $\mathrm{NO}_{\mathrm{x}}$ converter efficiency with a flow rate of $3.5 \mathrm{lpm}$ at temperatures of $300^{\circ} \mathrm{F}, 325^{\circ} \mathrm{F}$ and $350^{\circ} \mathrm{F}$ using Horiba catalyst. 


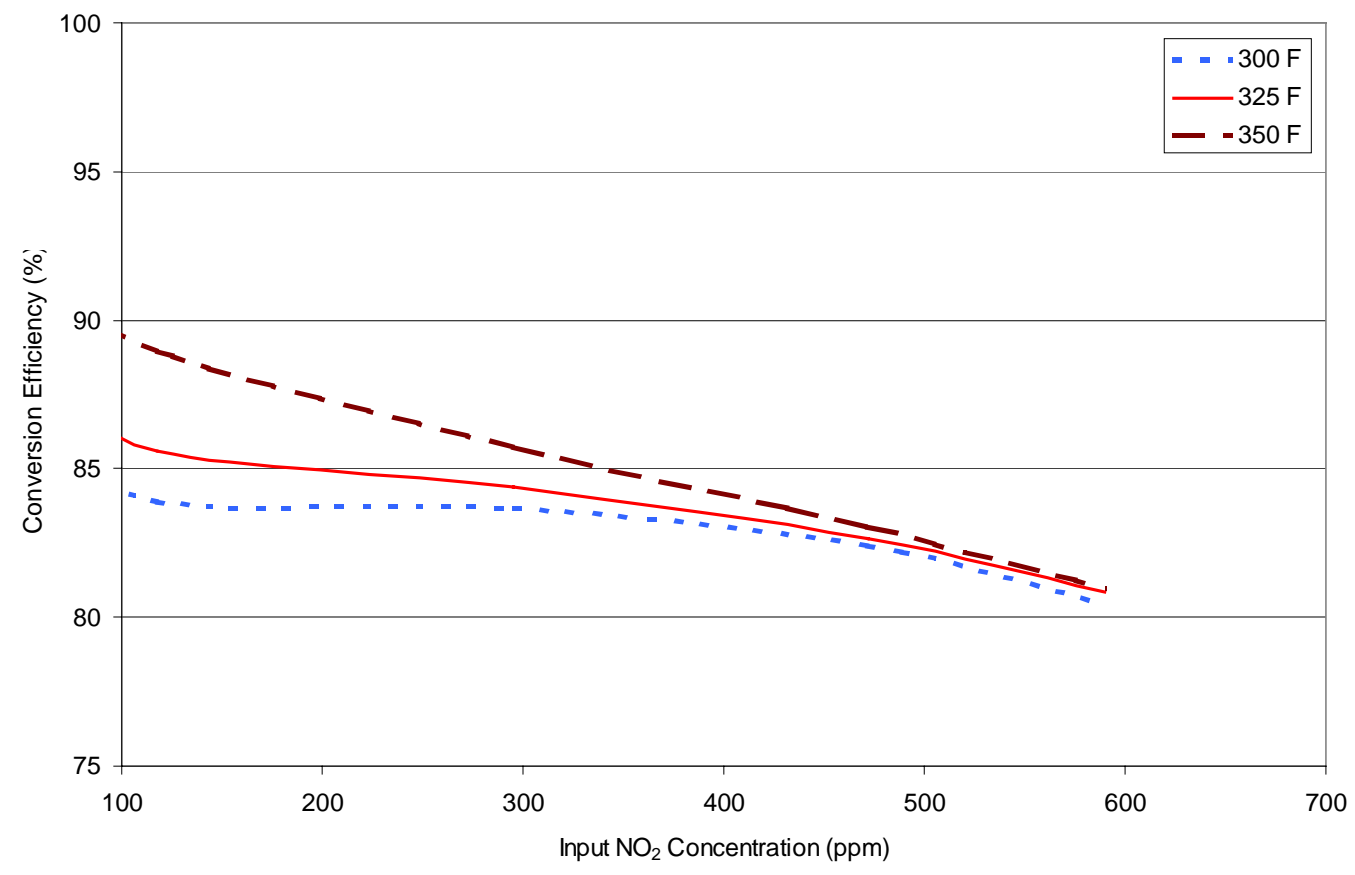

Figure 4.4 Comparison of the $\mathrm{NO}_{\mathrm{x}}$ converter efficiency with a flow rate of $3.0 \mathrm{lpm}$ at temperatures of $300^{\circ} \mathrm{F}, 325^{\circ} \mathrm{F}$ and $350^{\circ} \mathrm{F}$ using Vitreous Carbon catalyst.

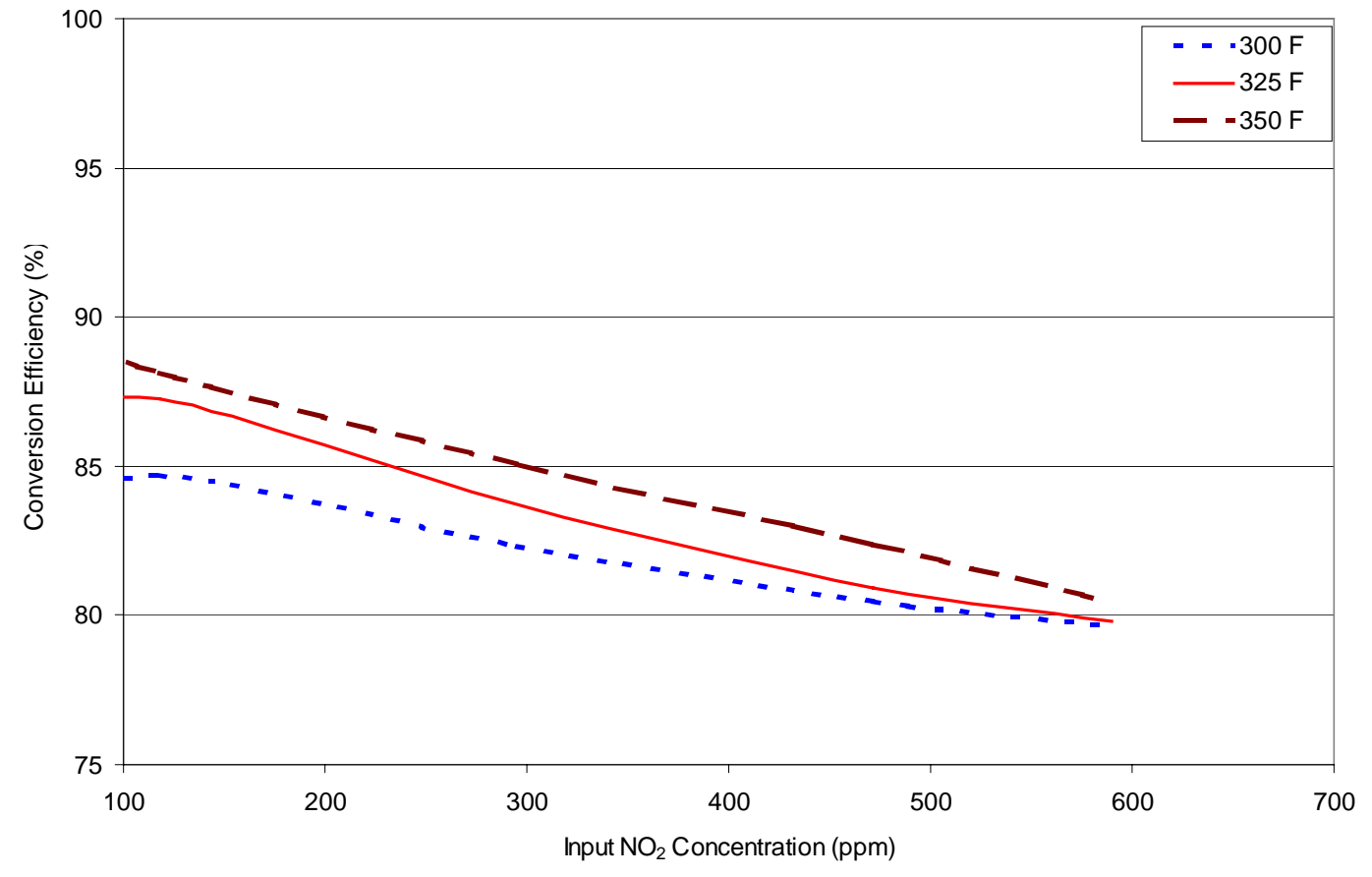

Figure 4.5 Comparison of the $\mathrm{NO}_{\mathrm{x}}$ converter efficiency with a flow rate of $3.5 \mathrm{lpm}$ at temperatures of $300^{\circ} \mathrm{F}, 325^{\circ} \mathrm{F}$ and $350^{\circ} \mathrm{F}$ using Vitreous Carbon catalyst. 


\subsection{Inference on the Optimum Conditions for the $\mathrm{NO}_{\mathrm{x}}$ converter}

Results of the various tests discussed in Section 4.6 are shown in Figure 4.2 to Figure 4.5 and the results suggests that the $\mathrm{NO}_{\mathrm{x}}$ converter efficiency is strongly dependent upon catalyst temperature and the residence time (flow rate). The converter efficiency was greater than $95 \%$ for $\mathrm{NO}_{2}$ concentrations less than $100 \mathrm{ppm}$. For concentrations in the range of 100-300ppm the converter efficiency was close to $90 \%$. For concentrations greater than $300 \mathrm{ppm}$ the efficiency was about $80-85 \%$.

It can be seen from Figure 4.2, Figure 4.3 Figure 4.4 and Figure 4.5 that the maximum converter efficiencies were obtained with a converter consisting of the Horiba catalyst, which was maintained at a temperature of $350^{\circ} \mathrm{F}$, and a sample flow rate of $3.01 \mathrm{pm}$. 


\section{ON-ROAD ROUTES}

The in-use testing conducted in this study was performed by WVU in partial fulfillment of the requirements of Phase III of the Consent Decrees. The EPA approved four routes that were defined by WVU in consultation with the settling manufacturers. These routes were meant to represent typical in-use vehicle applications, and consisted of both urban and highway segments. Two of the routes were comprised of primarily urban driving, while two routes were principally highway cycles. The following paragraph is a subsection of the Consent Decrees describing the route criteria 94 and the in-use testing routes are described in the following sections.

In Phase II of the In-Use Testing Program, the manufacturer shall develop in-use testing procedures to be used in connection with Phases III and IV of the In-Use Testing Program. The development of in-use testing procedures shall be based on testing of HDDE's engages in a variety of typical on-road emissions, and in a variety of seasonal conditions, and shall utilize engines extending over various stages of their Useful Life. The testing procedures shall include the identification of candidate driving routes representing typical urban, suburban and highway driving. The candidate routes shall be of sufficient length to take 45 minutes when driven at posted speeds. At least one (1) candidate driving route shall include a portion where at least 15 minutes of operation at 65 mph or greater is permitted and generally attained by trucks.

\subsection{Saltwell, WV}

This route was split into inbound and return journeys. The route originated at the WVU Sabraton facility (Greater Morgantown Area) close to an entrance ramp accessing I-68 west. The route proceeded to I-79, and followed I-79 south to the turnaround point at the I-79 Saltwell Rd. Exit (near Clarksburg, WV). The total distance was 58.7 miles. The interstate was posted at 70 mph, but there were two curves with advisory signs below that speed. The outbound leg was designated SAB2SW and the return leg was designated SW2SAB.

\subsection{Bruceton Mills, WV}

This route was divided into outbound and return journeys. The route originated at the WVU Sabraton facility (Greater Morgantown Area) close to an entrance ramp on I-68 east, and continued on I-68 where a climb of a sustained 5\% grade existed, followed by transient road grades to the turnaround point at Bruceton Mills, WV. The total distance was 39.7 miles. The interstate was posted at $70 \mathrm{mph}$, but the $5 \%$ descent on the return journey was posted at $50 \mathrm{mph}$ 
for trucks and was preceded by a mandatory truck stop for checking brakes. In the high-speed freeway operation, dramatic reductions in vehicle speed were encountered as the vehicle climbed hills along the route. In the case of this route, truck speed restrictions and necessary precautions during steep descent on the return leg of the journey reduced the operating speed on I-68 westbound. The outbound leg was designated as SAB2BM and the return leg was designated as BM2SAB.

\subsection{Pittsburgh (Mt. Morris), PA}

This route originate in Washington PA, which is located near the intersection of I-70 and I-79. The route proceeded from Washington on US Rte. 19 north through suburban areas toward Pittsburgh, followed PA State Rte. 51 (US truck Rte. 19) to I-279 south, to I-79 south, and then returned to the first rest area in West Virginia. For the first and second leg, the interstate speed limit was $55 \mathrm{mph}$ and the suburban speed limits varied from 25 to $45 \mathrm{mph}$. The final leg consisted of all highway driving with a transition from $55 \mathrm{mph}$ to $65 \mathrm{mph}$. The total distance was 87.4 miles. The first leg was designated as WASHPA1, the second leg as WASHPA2, and the third leg as WASHPA3.

\subsection{Morgantown, WV}

This route originated at the WVU Sabraton facility and proceeded through suburban and urban settings on two and four lane roads, then joined I-79 south and I-68 east, to return to the starting point. The total distance was 20.4 miles. Posted speeds of 35, 40 and $50 \mathrm{mph}$ existed on the urban and suburban routes, and the interstate sections were posted at $70 \mathrm{mph}$. Test vehicles with GVW in excess of 60,000 lbs. were not operated over this route due to weight limitations associated with the Star City bridge, in Morgantown that had major construction begin on it during the time lapse between Phases II and III of the Consent Decrees study. However, it is to be noted that a new bridge had been constructed at the time of writing of this thesis and an 80,000 lbs. GVW limit now exists. 


\subsection{In-use Testing}

The routes described in Chapter 5 were used to generate the on-road vehicle emissions data for engines from each SHDDE, and they are summarized in Table 6-1 Table 6-6. The engine dynamometer testing was performed on one of the in-field test engines from each SHDDE. The vehicle from which the engine was removed for laboratory testing is also indicated in Table 6-1 to Table 6-6. Route 1 was the Saltwell Route, Route 2 was the Morgantown Route, Route 3 was the Bruceton Mills Route and Route 4 was the Pittsburgh Route. Drivers operated the vehicles, through the different test routes, while WVU engineers and technicians operated the emissions measurement systems. A complete test for a test vehicle on a route comprised of three complete executions of the route.

Table 6-1 Summary of test routes performed for each vehicle with Caterpillar engine

\begin{tabular}{|c|c|c|c|c|c|c|}
\hline $\begin{array}{c}\text { Vehicle } \\
\text { ID }\end{array}$ & Engine Model & Route 1 & Route 2 & Route 3 & Route 4 & $\begin{array}{c}\text { Engine } \\
\text { Dynamometer }\end{array}$ \\
\hline 1 & 1996 3406E 475hp & $\mathrm{X}$ & & $\mathrm{X}$ & $\mathrm{X}$ & $\mathrm{X}$ \\
\hline 2 & 1996 3406E 475hp & $\mathrm{X}$ & & $\mathrm{X}$ & $\mathrm{X}$ & \\
\hline 3 & 1998 3406E 475hp & $\mathrm{X}$ & & $\mathrm{X}$ & $\mathrm{X}$ & \\
\hline 4 & 1998 3406E 475hp & $\mathrm{X}$ & & $\mathrm{X}$ & $\mathrm{X}$ & \\
\hline 5 & $19983406 \mathrm{E}$ & $\mathrm{X}$ & & $\mathrm{X}$ & $\mathrm{X}$ & \\
\hline 6 & 1997 3406E 434hp & $\mathrm{X}$ & & $\mathrm{X}$ & $\mathrm{X}$ & \\
\hline 7 & 1996 3176B 300hp & $\mathrm{X}$ & & $\mathrm{X}$ & $\mathrm{X}$ & \\
\hline 8 & $19963176 \mathrm{~B} 300 \mathrm{hp}$ & $X$ & & $X$ & $X$ & \\
\hline 9 & $19983126190 \mathrm{hp}$ & $\mathrm{X}$ & & $\mathrm{X}$ & $\mathrm{X}$ & \\
\hline 10 & C12 410hp & $\mathrm{X}$ & & $\mathrm{X}$ & $\mathrm{X}$ & \\
\hline
\end{tabular}

Table 6-2 Summary of test routes performed for each vehicle with International Engine

\begin{tabular}{|c|c|c|c|c|c|c|}
\hline $\begin{array}{l}\text { Vehicle } \\
\text { ID }\end{array}$ & Engine Model & Route 1 & Route 2 & Route 3 & Route 4 & $\begin{array}{c}\text { Engine } \\
\text { Dynamometer }\end{array}$ \\
\hline 1 & $2001 \mathrm{DT} 466 \mathrm{E}$ & $\mathrm{X}$ & $\mathrm{X}$ & & $\mathrm{X}$ & \\
\hline 2 & $2001 \mathrm{DT} 466 \mathrm{E}$ & $\mathrm{X}$ & $\mathrm{X}$ & & $\mathrm{X}$ & \\
\hline 3 & 1999 B250 & $\bar{X}$ & & $\mathrm{X}$ & $\bar{X}$ & $\mathrm{X}$ \\
\hline
\end{tabular}


Table 6-3 Summary of test routes performed for each vehicle with Cummins engine

\begin{tabular}{|c|c|c|c|c|c|c|}
\hline $\begin{array}{c}\text { Vehicle } \\
\text { ID }\end{array}$ & Engine Model & Route 1 & Route 2 & Route 3 & Route 4 & $\begin{array}{c}\text { Engine } \\
\text { Dynamometer }\end{array}$ \\
\hline 1 & 1996 N14-435 E+ & $\mathrm{X}$ & & $\mathrm{X}$ & $\mathrm{X}$ & \\
\hline 2 & 1997 N14-470 & $\mathrm{X}$ & & $\mathrm{X}$ & $\mathrm{X}$ & \\
\hline 3 & 1998 N14-435 ESP & $\mathrm{X}$ & & $\mathrm{X}$ & $\mathrm{X}$ & \\
\hline 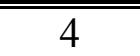 & 1997 M11-350 E+ & $\bar{X}$ & & $\bar{X}$ & $\overline{\mathrm{X}}$ & $\bar{X}$ \\
\hline 5 & $1998 \mathrm{~N}-14435 \mathrm{E}+$ & $\mathrm{X}$ & & $\mathrm{X}$ & $\mathrm{X}$ & \\
\hline$\overline{6}$ & $1998 \mathrm{~N}-14$ 460E+ & $\bar{X}$ & & $\bar{X}$ & $\bar{X}$ & \\
\hline$\overline{77}$ & 1997 N-14 370/435 & $\overline{\mathrm{X}}$ & & $\bar{X}$ & $\bar{X}$ & \\
\hline 8 & 1998 M11 330/370 & $\bar{X}$ & & $\bar{X}$ & $\mathrm{X}$ & \\
\hline 9 & 1996 M-11 350 ESP & $\bar{X}$ & & $\bar{X}$ & $\mathrm{X}$ & \\
\hline 10 & 1996 M-11 350 ESP & $\bar{X}$ & & $\bar{X}$ & $\bar{X}$ & \\
\hline
\end{tabular}

Table 6-4 Summary of test routes performed for each vehicle with DDC engine

\begin{tabular}{|c|c|c|c|c|c|c|}
\hline $\begin{array}{c}\text { Vehicle } \\
\text { ID }\end{array}$ & Engine Model & Route 1 & Route 2 & Route 3 & Route 4 & $\begin{array}{c}\text { Engine } \\
\text { Dynamometer }\end{array}$ \\
\hline 1 & 1996 Series $50275 \mathrm{hp}$ & $\mathrm{X}$ & $\mathrm{X}$ & & $\mathrm{X}$ & \\
\hline 2 & 1996 Series $50275 \mathrm{hp}$ & $\mathrm{X}$ & $\mathrm{X}$ & & $\mathrm{X}$ & \\
\hline 3 & 1994 Series 60 370hp & $\mathrm{X}$ & & $\mathrm{X}$ & $\mathrm{X}$ & $\mathrm{X}$ \\
\hline 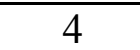 & 1995 Series $60430 \mathrm{hp}$ & $\bar{X}$ & & $\bar{X}$ & $\bar{X}$ & \\
\hline 5 & 1995 Series 60 430hp & $\mathrm{X}$ & & $\bar{X}$ & $\mathrm{X}$ & \\
\hline 6 & 1995 Series $60430 \mathrm{hp}$ & $\bar{X}$ & & $\bar{X}$ & $\bar{X}$ & \\
\hline 7 & 1994 Series 60 470hp & $\bar{X}$ & & $\bar{X}$ & $X$ & \\
\hline 8 & 1995 Series $60430 \mathrm{hp}$ & $\bar{X}$ & & $\bar{X}$ & $\bar{X}$ & \\
\hline 9 & 1998 Series $60430 \mathrm{hp}$ & $\mathrm{X}$ & & $\mathrm{X}$ & $\mathrm{X}$ & \\
\hline 10 & 1998 Series $60370 \mathrm{hp}$ & $\bar{X}$ & & $\bar{X}$ & $\bar{X}$ & \\
\hline
\end{tabular}

Table 6-5 Summary of test routes performed for each vehicle with Mack engine

\begin{tabular}{|c|c|c|c|c|c|c|}
\hline $\begin{array}{c}\text { Vehicle } \\
\text { ID }\end{array}$ & Engine Model & Route 1 & Route 2 & Route 3 & Route 4 & $\begin{array}{c}\text { Engine } \\
\text { Dynamometer }\end{array}$ \\
\hline 1 & 1995 E7-400 & $\mathrm{X}$ & & $\mathrm{X}$ & $\bar{X}$ & $\bar{X}$ \\
\hline 2 & 1995 E7-350 & $\mathrm{X}$ & & $\bar{X}$ & $\bar{X}$ & \\
\hline 3 & 1994 E7-350 & $\mathrm{X}$ & & $\mathrm{X}$ & $\mathrm{X}$ & \\
\hline
\end{tabular}


Table 6-6 Summary of test routes performed for each vehicle with Volvo engine

\begin{tabular}{|c|c|c|c|c|c|c|}
\hline $\begin{array}{l}\text { Vehicle } \\
\text { ID }\end{array}$ & Engine Model & Route 1 & Route 2 & Route 3 & Route 4 & $\begin{array}{c}\text { Engine } \\
\text { Dynamometer }\end{array}$ \\
\hline 1 & 1998 VE D123-425 & $\mathrm{X}$ & & $\mathrm{X}$ & $\mathrm{X}$ & $\mathrm{X}$ \\
\hline 2 & 1998 VE D123-425 & $\mathrm{X}$ & & $\mathrm{X}$ & $\mathrm{X}$ & \\
\hline
\end{tabular}

\subsection{Engine Dynamometer Emissions Testing}

The engine dynamometer tests were performed at the WVU-EERC on a GE DC dynamometer. Emissions testing in the engine test cell was done using a full-flow doubledilution (CFV-CVS) system that was designed and operated in accordance to the procedure and recommendations set forth by the $40 \mathrm{CFR}$, Part 86, Subpart N. Laboratory engine testing required removal of engines from each of the test vehicle that was earmarked for laboratory testing.

On the dynamometer, engines were exercised over the FTP test schedule and also on two steady-state modes that represented the operating conditions of peak engine torque and maximum engine power. Also, a simulated on-road transient test route was developed and engines were tested over the simulated cycle. The methodology used for generation of the simulated in-use cycles in described briefly in the Phase III Report [5]. The test cycles that were used for each of the engines are summarized in Table 6.7. The results from various engine tests are discussed and analyzed in detail in 66. This report presents results from only one engine that was operated on the three on-road routes, two steady state modes, FTP and the SAB2BM simulated route.

Table 6-7 Summary of engine dynamometer testing

\begin{tabular}{|c|c||c||c||c|c||c||c||c||}
\hline \hline Engine Make & FTP & SS01 & SS02 & SAB2BM & BM2SAB & SAB2SW & PA1 & PA2 \\
\hline \hline Caterpillar & $\mathrm{X}$ & $\mathrm{X}$ & $\mathrm{X}$ & $\mathrm{X}$ & $\mathrm{X}$ & & $\mathrm{X}$ & $\mathrm{X}$ \\
\hline \hline Cummins & $\mathrm{X}$ & $\mathrm{X}$ & $\mathrm{X}$ & $\mathrm{X}$ & $\mathrm{X}$ & $\mathrm{X}$ & & \\
\hline \hline $\mathrm{DDC}$ & $\mathrm{X}$ & $\mathrm{X}$ & $\mathrm{X}$ & $\mathrm{X}$ & $\mathrm{X}$ & $\mathrm{X}$ & $\mathrm{X}$ & \\
\hline $\mathrm{Navistar}$ & $\mathrm{X}$ & $\mathrm{X}$ & $\mathrm{X}$ & $\mathrm{X}$ & & & & \\
\hline \hline Mack & $\mathrm{X}$ & $\mathrm{X}$ & $\mathrm{X}$ & $\mathrm{X}$ & $\mathrm{X}$ & & $\mathrm{X}$ & \\
\hline \hline Volvo & $\mathrm{X}$ & $\mathrm{X}$ & $\mathrm{X}$ & $\mathrm{X}$ & $\mathrm{X}$ & & $\mathrm{X}$ & \\
\hline
\end{tabular}




\section{UNCERTANTY ANALYSIS}

\subsection{Introduction}

Every measurement is a combination of the true value of the parameter plus the total measurement error. Hence, there is an inherent uncertainty in the use of the measurements to represent a true value. This makes completely accurate measurements impossible. The total

uncertainty in a measurement is a combination of uncertainty due to systematic error and uncertainty due to random error. The uncertainty or error analysis is the process of establishing these combined errors.

\subsection{Assumptions}

The following are the major assumptions that are made during the measurement uncertainty analysis [54,55,

- The test process is defined;

- The measurement system and test process are controlled;

- The appropriate calibration corrections are applied;

- The test objectives are specified;

- The instrument package and data reduction procedures are defined; and

- For purpose of total uncertainty calculations, 95\% confidence levels have been used.

\subsection{Classification of Measurement Error}

The total measurement error consists of two components namely, systematic or bias error and random error.

\subsubsection{Random Error}

Random error is the portion of the total measurement error that varies in repeated measurements of the true value. The total random error in a measurement is the sum of the contributions of several elemental random error sources. Elemental random errors may arise from non-repeatability in the measurement system, environmental conditions, data reduction techniques and measurement methods.

\subsubsection{Systematic Error}

Systematic error is the proportion of the total measurement error that remains constant in repeated measurements of the true value. The total bias error in a measurement is the sum of the 
contributions of several elemental systematic errors. Sources of elemental bias errors are imperfect calibration correction, data acquisition systems, data reduction techniques etc.

\subsection{Classification of Components of Uncertainty}

The total uncertainty in a measurement is the combination of uncertainty due to systematic error and uncertainty due to random error.

\subsubsection{Uncertainty due to Random Error}

Random error introduces scatter in repeated measurements of a parameter. The population standard deviation is a measure of the scatter about the true population mean. It is assumed that the random error follows the normal distribution and has been used for the calculation of errors.

\subsubsection{Uncertainty due to Bias Error}

The uncertainty due to the systematic error cannot be quantified; hence, has to be estimated. The systematic error is an estimate of the systematic error calculated at $95 \%$ confidence.

\subsection{Classification of Type of Uncertainty evaluation}

The uncertainty is evaluated by two methods-Type A and Type B.

\subsubsection{Type A Evaluation}

The evaluation of uncertainty by the statistical analysis of series of observations is termed as Type A evaluation of uncertainty.

\subsubsection{Type B Evaluation}

The evaluation of uncertainty by means other than the statistical analysis of series of observations is termed as Type B evaluation of uncertainty.

\subsection{Measurement Uncertainty Sources}

Uncertainty in a measurement process may be introduced from the following sources: calibration, data acquisition, data reduction, and methods.

\subsubsection{Calibration Uncertainty}

Calibration is the process of feeding known input values into the measurement system and recording the output to use as a reference when reducing data. The main purpose of calibration process is to eliminate large, known systematic errors and thus reduce the measurement uncertainty to some acceptable level. 


\subsubsection{Data Acquisition Uncertainty}

Uncertainty in data acquisition systems can arise from errors in the signal conditioning, the sensors, the recording devices etc. Overall system calibration reduces the effects of these uncertainty sources. The overall uncertainty is evaluated by combining each of the elemental uncertainties.

\subsubsection{Data Reduction Uncertainty}

Mostly the data is presented in engineering units. Converting the raw data by performing necessary computations does this. Typical uncertainty sources arise from curve fit errors and the computational resolution.

\subsubsection{Uncertainty due to Methods}

Uncertainties due to methods are defined as those additional uncertainty sources that originate from the techniques or methods inherent in the measurement system. Some of them include:

1. Uncertainty in the assumptions or constants contained in the calculation routines;

2. Uncertainty due to intrusive disturbance effects caused by installed instrumentation;

3. Environmental effects on probes such as heat transfer effects;

4. Uncertainty due to instability, non-repeatability, and hysteresis of the test process.

5. The uncertainties may be of either random or bias nature depending on their effect on the measurement.

\subsection{Propagation of Uncertainty}

The objective of the error model is to assess the contribution of individual measurement uncertainties to the final result. The procedures have been described in National Institute of Standards for the purpose 54. They are

1. Identify the error sources.

2. Estimate random and bias errors for each of the sources.

3. Estimate any propagation of error through the result. 


\subsubsection{Absolute Summation}

Absolute summation uses a special application of Taylor's series, ignoring higher order terms for analysis. The determination of uncertainty was done by considering a quantity $\mathrm{N}$, where $\mathrm{N}$ is a function of known variables.

$$
\mathrm{N}=f\left(\mathrm{x}_{1}, \mathrm{x}_{2}, \mathrm{x}_{3} \ldots \mathrm{x}_{\mathrm{n}}\right)
$$

The absolute error is given by:

$$
\Delta N=\left|\frac{\partial N}{\partial x_{1}} * \Delta x_{1}\right|+\left|\frac{\partial N}{\partial x_{2}} * \Delta x_{2}\right|+\ldots . .+\left|\frac{\partial N}{\partial x_{n}} * \Delta x_{n}\right|
$$

$\Delta x_{1}, \Delta x_{1}, . ., \Delta x_{n}$ are the maximum uncertainties associated with the respective variables. This method gives the overall maximum uncertainty of the function. The assumption made in this method is that the uncertainties are expressed as equally probable plus and minus values.

\subsubsection{Root-Sum of Squares Method}

The "Guide to the Expression of Uncertainty in Measurement" 545556 recommends the use of Root-Sum Squares method (RSS) for calculation of uncertainty. The uncertainty in this method is expressed as the partial derivative with respect to each variable in the equation multiplied by its individual maximum uncertainty and squared, these quantities are summed and then the square root is taken. For $\mathrm{N}$ a function of known variables,

$$
\begin{aligned}
& \mathrm{N}=f\left(\mathrm{x}_{1}, \mathrm{x}_{2}, \mathrm{x}_{3}, \ldots . \mathrm{x}_{\mathrm{n}}\right) \\
& \Delta N=\left[\left(\frac{\partial N}{\partial x_{1}} * \Delta x_{1}\right)^{2}+\left(\frac{\partial N}{\partial x_{2}} * \Delta x_{2}\right)^{2}+\ldots . .+\left(\frac{\partial N}{\partial x_{n}} * \Delta x_{n}\right)^{2}\right]^{1 / 2}
\end{aligned}
$$

RSS is the method used throughout this thesis to define the uncertainty ranges for measurements made with the MEMS. 


\subsection{Uncertainty in Brake Specific Emissions}

To determine the uncertainty in the measurement of brake specific emissions of $\mathrm{NO}_{\mathrm{x}}$ and $\mathrm{CO}_{2}$, the following equations were used.

$$
\begin{aligned}
& b s N O_{x}=\left(\frac{\frac{\left(N O_{x, p p m}\right)}{10^{6}} * Q_{s} * \rho * t}{b h p}\right) \\
& b s \mathrm{CO}_{2}=\left(\frac{\frac{\left(C O_{2, p p m}\right)}{10^{6}} * Q_{s} * \rho^{*} t}{b h p}\right)
\end{aligned}
$$

where,

bsNO ${ }_{\mathrm{x}}=$ brake specific emissions of $\mathrm{NO}_{\mathrm{x}}$ in $\mathrm{g} / \mathrm{bhp}-\mathrm{hr}$

bs $\mathrm{CO}_{2}=$ brake specific emissions of $\mathrm{CO}_{2}$ in $\mathrm{g} / \mathrm{bhp}-\mathrm{hr}$

$\mathrm{NO}_{\mathrm{x}, \mathrm{ppm}}=$ concentration of oxides of nitrogen in ppm

$\mathrm{CO}_{2, \mathrm{ppm}}=$ concentration of carbon dioxide in ppm

$\mathrm{Q}_{\mathrm{s}}=$ exhaust flow rate in scfm

bhp-hr= work done or energy

$\rho=$ density of the gas in $\mathrm{lb} / \mathrm{ft}^{3}$

$\mathrm{t}=$ time in seconds

Using the Root-Mean Square method, and assuming the density to be a constant, the uncertainty in the brake specific emissions may be expressed as:

$$
\begin{aligned}
& \Delta b s N O_{x}=\left[\left(\frac{\partial b s N O_{x}}{\partial N O_{x}} * \Delta N O_{x}\right)^{2}+\left(\frac{\partial b s N O_{x}}{\partial Q_{s}} * \Delta Q_{s}\right)^{2}+\left(\frac{\partial b s N O_{x}}{\partial b h p} * \Delta b h p\right)\right]^{1 / 2} \\
& \Delta b s \mathrm{CO}_{2}=\left[\left(\frac{\partial b s \mathrm{CO}_{2}}{\partial \mathrm{CO}_{2}} * \Delta C \mathrm{O}_{2}\right)^{2}+\left(\frac{\partial b s \mathrm{CO}_{2}}{\partial Q_{s}} * \Delta Q_{s}\right)^{2}+\left(\frac{\partial b s C O_{2}}{\partial b h p} * \Delta b h p\right)\right]^{1 / 2}
\end{aligned}
$$

where,

$\Delta \mathrm{bsNO}_{\mathrm{x}}=$ uncertainty in the bsNOx measurement 
$\Delta \mathrm{bsCO}_{2}=$ uncertainty in the $\mathrm{bsCO}_{2}$ measurement

$\Delta \mathrm{Q}_{\mathrm{s}}=$ uncertainty in the exhaust flow rate measurement

$\Delta \mathrm{bhp}-\mathrm{hr}=$ uncertainty in the energy measurement

The first variability considered in the brake specific emissions measurements was the exhaust flow rate. The exhaust flowrate was measured using the Annubar, which was described earlier in Chapter 3 To determine the uncertainty in the exhaust flow rate, the following equation was used.

$$
\mathrm{Q}_{\mathrm{s}}=\mathrm{F}_{\mathrm{NA}} * \mathrm{~K} * \mathrm{D}^{2} * \mathrm{~F}_{\mathrm{RA}} * \mathrm{Y}_{\mathrm{A}} * \mathrm{~F}_{\mathrm{pb}} * \mathrm{~F}_{\mathrm{tb}} * \mathrm{~F}_{\mathrm{tf}} * \mathrm{~F}_{\mathrm{s}} * \mathrm{~F}_{\mathrm{pv}} * \mathrm{~F}_{\mathrm{m}} * \mathrm{~F}_{\mathrm{AA}} * \mathrm{~F}_{1} * \sqrt{h_{w} * P_{f} *(14.96 / 29.92)}
$$

where,

$\mathrm{D}=$ Internal Diameter of pipe, inches

$\mathrm{F}_{\mathrm{AA}}=$ Thermal Expansion Factor.

$\mathrm{F}_{\mathrm{g}}=$ Specific Gravity Factor, assumed constants.

$\mathrm{F}_{1}=$ Gage Location Factor, assumed constant.

$\mathrm{F}_{\mathrm{m}}=$ Manometer Factor, assumed constant.

$\mathrm{F}_{\mathrm{NA}}=$ Units Conversion Factor, assumed constant.

$\mathrm{F}_{\mathrm{pb}}=$ Pressure Base Factor, assumed constant.

$\mathrm{F}_{\mathrm{pv}}=$ Supercompressibility Factor, assumed constant.

$\mathrm{F}_{\mathrm{RA}}=$ Reynolds Number Factor, assumed constant.

$\mathrm{F}_{\mathrm{tb}}=$ Temperature Base Factor, assumed constant.

$\mathrm{F}_{\mathrm{tf}}=$ Flowing Temperature Factor.

$\mathrm{h}_{\mathrm{W}}=$ Differential pressure as measured by the Annubar primary element.

$\mathrm{K}=$ Flow Coefficient.

$\mathrm{P}_{\mathrm{f}}=$ Flowing Pressure.

$\mathrm{Y}_{\mathrm{A}}=$ Expansion Factor.

The error associated with the total mass flow rate was calculated as follows.

$$
\Delta Q_{s}=\left[\left(\frac{\partial Q_{s}}{\partial K} * K\right)^{2}+\left(\frac{\partial Q}{\partial Y_{A}} * \Delta Y_{A}\right)^{2}+\left(\frac{\partial Q}{\partial F_{A A}} * \Delta F_{A A}\right)^{2}+\left(\frac{\partial Q}{\partial F_{t f}} * \Delta F_{t f}\right)^{2}+\left(\frac{\partial Q_{S}}{\partial h_{w}} * \Delta h_{w}\right)^{2}+\left(\frac{\partial Q_{s}}{\partial P_{f}} * \Delta P_{f}\right)^{2}\right]^{1 / 2}
$$


The Flow coefficient K was determined by calibrating the Annubar against the LFE. The uncertainty in the $\mathrm{K}$ value was determined as follows.

$$
\Delta K=\left[\left(\frac{\partial K}{\partial Q^{\prime}} * \Delta Q^{\prime}\right)^{2}+\left(\frac{\partial K}{\partial h_{w}} * \Delta h_{w}\right)^{2}+\left(\frac{\partial K}{\partial P_{f}} * \Delta P_{f}\right)^{2}\right]^{1 / 2}
$$

where,

$Q^{\prime}=$ volumetric flow rate through the LFE in scfm.

The flow rate was measured with a Laminar Flow Element (LFE) using the following equation.

$$
Q^{\prime}=\left(B * D P+C * D P^{2}\right) *\left(\frac{\mu_{s t d}}{\mu_{f}}\right) *\left(\frac{T_{s t d}}{T}\right) *\left(\frac{P_{f}}{P_{s t d}}\right)
$$

where,

$\mathrm{B}$ and $\mathrm{C}=$ calibration constants for the LFE.

$\mathrm{DP}=$ differential pressure across the LFE in inches of water.

$\mu_{s t d}=$ viscosity of flowing gas at $70 \mathrm{~F}$ in micropoise.

$\mu_{f}=$ viscosity of flowing gas at flowing temperature in micropoise.

$\mathrm{T}_{\text {std }}=$ standard temperature in Fahrenheit.

$\mathrm{T}_{\mathrm{f}}=$ flowing gas temperature in Fahrenheit.

$\mathrm{P}_{\text {std }}=$ standard pressure in inches of mercury.

$\mathrm{P}_{\mathrm{f}}=$ flowing pressure in inches of mercury.

The uncertainty in the flow rate measured using the LFE is given by:

$$
\Delta Q^{\prime}=\left[\left(\frac{\partial Q^{\prime}}{\partial D P} * \Delta D P\right)^{2}+\left(\frac{\partial Q^{\prime}}{\partial T} * \Delta T\right)^{2}+\left(\frac{\partial Q^{\prime}}{\partial P_{f}} * \Delta P_{f}\right)^{2}\right]
$$

where,

$\Delta \mathrm{DP}=$ uncertainty in the differential pressure measurement.

$\Delta \mathrm{T}=$ uncertainty in the temperature measurement.

$\Delta \mathrm{P}_{\mathrm{f}}=$ uncertainty in the absolute pressure measurement. 
The LFE absolute pressure and the differential pressure were measured using a Digital calibrator type Heise PTE-1.The total error in each of the measurement is listed in Table 7-1.

The LFE inlet temperature was measured with a Fluke 714 Thermocouple Calibrator. The total error in the measurement of temperature is listed in Table 7-1.

Table 7-1 List of instruments used for differential $\&$ absolute pressure and temperature measurement

\begin{tabular}{||l||c||c||l||}
\hline \multicolumn{1}{|c||}{ Parameter } & Manufacturer & \multicolumn{1}{|c|}{ Model } & \multicolumn{1}{|c|}{ Accuracy } \\
\hline \hline Differential Pressure & Heise & HQS-1 & $\pm 0.06 \%$ of Span \\
\hline \hline Absolute Pressure & Heise & HQS-2 & $\pm 0.025 \%$ of Span \\
\hline \hline Temperature & Fluke & $\begin{array}{l}\text { 714 Thermocouple } \\
\text { Calibrator }\end{array}$ & $\begin{array}{l} \pm 0.025 \% \text { of } \\
\text { Reading }\end{array}$ \\
\hline
\end{tabular}

The annubar absolute pressure was measured using a Omega PX-213 pressure transducer. The total error in the measurement is listed in Table 7-2.

Table 7-2 Errors in absolute pressure measurement

\begin{tabular}{||c||c||c||c||}
\hline Source & Manufacturer & Model Number & $\begin{array}{c}\text { Applied Error } \\
\% \text { of Full Scale }\end{array}$ \\
\hline \hline $\begin{array}{c}\text { Absolute Pressure } \\
\text { Sensor }\end{array}$ & Omega Inc. & PX213 & $\pm 0.250 \%$ \\
\hline \hline $\begin{array}{c}\text { Signal Conditioner } \\
\text { Module }\end{array}$ & $\begin{array}{c}\text { National } \\
\text { Instruments Inc. }\end{array}$ & SCC-AI04 & $\pm 0.100 \%$ \\
\hline \hline DAQ Board & $\begin{array}{c}\text { National } \\
\text { Instruments Inc. }\end{array}$ & NI-6024E & $\pm 0.024 \%$ \\
\hline \hline
\end{tabular}

The annubar differential pressure was measured with a Validyne P55D differential pressure transducer. The total error in the measurement is listed in Table 7-3.

Table 7-3 Errors in differential pressure measurement

\begin{tabular}{|c|c|c|c|}
\hline Source & Manufacturer & Model Number & $\begin{array}{l}\text { Applied Error } \\
\% \text { of Full Scale }\end{array}$ \\
\hline $\begin{array}{l}\text { Differential Pressure } \\
\text { Sensor }\end{array}$ & Omega Inc. & P55D & $\pm 0.250 \%$ \\
\hline $\begin{array}{l}\text { Signal Conditioner } \\
\text { Module }\end{array}$ & $\begin{array}{l}\text { National } \\
\text { Instruments Inc. }\end{array}$ & SCC-AI04 & $\pm 0.100 \%$ \\
\hline DAQ Board & $\begin{array}{l}\text { National } \\
\text { Instruments Inc. }\end{array}$ & NI-6024E & $\pm 0.024 \%$ \\
\hline
\end{tabular}


The annubar inlet temperature was measured with the Omega J-type Thermocouple. The total error in the measurement of temperature is listed in Table 7-4.

Table 7-4 Error in temperature measurement

\begin{tabular}{|l||l||c||c||}
\hline Source & Manufacturer & Model Number & $\begin{array}{l}\text { Applied Error } \\
\% \text { of Full Scale }\end{array}$ \\
\hline \hline Temperature Sensor & Omega Inc. & J- Type & $\pm 0.250 \%$ \\
\hline \hline $\begin{array}{l}\text { Signal Conditioner } \\
\text { Module }\end{array}$ & $\begin{array}{l}\text { National } \\
\text { Instruments Inc. }\end{array}$ & SCC-TC02 & $\pm 0.080 \%$ \\
\hline \hline DAQ Board & $\begin{array}{l}\text { National } \\
\text { Instruments Inc. }\end{array}$ & NI-6024E & $\pm 0.024 \%$ \\
\hline
\end{tabular}

Using Equations 7.11, 7.12 and 7.13, the uncertainty in the $\mathrm{K}$ value of the Annubar can be calculated.

The Expansion factor is expressed as follows:

$$
Y_{A}=1-\left(\left((1-B)^{2} * 0.011332-0.00342\right) *\left(\frac{h_{w}}{P_{f} * \gamma}\right)\right)
$$

where,

$$
B=\frac{4 d}{\pi D}
$$

$\mathrm{B}=$ Blockage

$\mathrm{D}=$ Internal pipe diameter

$d=0.173$ for shape 10

$=0.365$ for shape $15 / 16$

$=0.856$ for shape $25 / 26$

$\mathrm{h}_{\mathrm{w}}=$ Differential pressure as measured by the Annubar primary element.

$\mathrm{P}_{\mathrm{f}}=$ Flowing pressure.

$\gamma=$ Ratio of specific heats.

The ratio of specific heats is expressed as:

$$
\begin{gathered}
\gamma=-3.34642 E-16 *(T+273)^{5}+9.26157 E-14(T+273)^{4}-7.64644 E-10 *(T+273)^{3} \\
+6.48889 E-8 *(T+273)^{2}+0.0000514974 *(T+273)+1.3927
\end{gathered}
$$


The error in the value of ratio of specific heats is given by:

$$
\Delta \gamma=\left[\left(\frac{\partial \gamma}{\partial T} * \Delta T\right)^{2}\right]^{1 / 2}
$$

From this the uncertainty in the expansion factor is calculated as:

$$
\Delta Y_{A}=\left[\left(\frac{\partial Y_{A}}{\partial h_{w}} * \Delta h_{w}\right)^{2}+\left(\frac{\partial Y_{A}}{\partial P_{f}} * \Delta P_{f}\right)^{2}+\left(\frac{\partial Y_{A}}{\partial \gamma} * \Delta \gamma\right)^{2}\right]^{1 / 2}
$$

The uncertainty in the annubar absolute pressure, annubar differential pressure, thermal expansion factor, temperature base factor, and flowing temperature factor can be calculated using Equations 7.18-7.22.

$$
\begin{gathered}
\frac{\partial Q_{s}}{\partial F_{t f}}=\frac{Q_{s}}{F_{t f}} \\
\frac{\partial Q_{s}}{\partial F_{A A}}=\frac{Q_{s}}{F_{A A}} \\
\frac{\partial Q_{s}}{\partial h_{w}}=\frac{Q_{s}}{2 h_{w}} \\
\frac{\partial Q_{s}}{\partial P_{f}}=\frac{Q_{s}}{2 P_{f}}
\end{gathered}
$$

Inserting the values from equations 7.5,7.22,7.19,7.20,7.21 and 7.22 and the values of $\Delta \mathrm{h}_{\mathrm{w}}, \Delta \mathrm{P}_{\mathrm{f}}$ and $\Delta \mathrm{T}$ into equation 7.10 gives the value of the uncertainty in the exhaust flow rate measurement $\left(\Delta \mathrm{Q}_{\mathrm{s}}\right)$.

\subsection{Calculation of Uncertainty of Concentration Values}

\subsubsection{Calibration Error}

The error from the gas analyzer calibration is associated with the uncertainties in the reported calibration gas concentration, the gas divider, the signal conditioner and the conversion of ADC codes to engineering unit values. The manufacturer-supplied values of accuracies of each of them are given the Table 7-5. 
Table 7-5 Specifications of instruments used in gaseous concentration measurement

\begin{tabular}{|l||l||l||l||}
\hline Source & Manufacturer & Model No. & Applied Error \\
\hline \hline Calibration Gas & Scott Specialty Gases & N/A & $\pm 1.00 \%$ \\
\hline \hline Gas Divider & STEC Inc. & SGD- 710C & $\pm 0.540 \%$ \\
\hline \hline Signal Conditioner & National Instruments & SCC- AI-04 & $\pm 0.100 \%$ \\
\hline \hline DAQ- Board & National Instruments & $6024-\mathrm{E}$ & $\pm 0.024 \%$ \\
\hline
\end{tabular}

$R_{\text {cal }}=\sqrt{1.0^{2}+0.54^{2}+0.1^{2}+0.0244^{2}}= \pm 1.14 \%$ of full scale

\subsubsection{Data Reduction Error}

The uncertainty introduced in the data reduction process is from the goodness of fit of the models used from the calibration curves.

$$
\text { Curvefit }_{\text {error }}=\sqrt{\frac{\left(y_{\text {real }}-y_{\text {curvefit }}\right)^{2}}{v}} * t_{v, 95}
$$

where,

$v=n-p+1$

$\mathrm{n}=$ number of data points summed.

$\mathrm{p}=$ order of the fit equation.

$\mathrm{t}_{\mathrm{v}, 95}=$ student $\mathrm{t}$ - distribution

\subsubsection{Analyzer Error}

Table 7-6 Specifications of gas analyzers used

\begin{tabular}{|c||c||c||c||}
\hline \hline Analyzer & Manufacturer & Model & \% Error \\
\hline \hline $\mathrm{CO}_{2}$ & Horiba Inc. & BE-140 & $\pm 2 \%$ of Full Scale reading \\
\hline \hline $\mathrm{NO}_{\mathrm{x}}$ & Horiba Inc. & MEXA- 120 & $\begin{array}{c} \pm 30 \mathrm{ppm}<1000 \mathrm{ppm} \\
\pm 3 \% \text { reading for } 1000-2000 \mathrm{ppm}\end{array}$ \\
\hline
\end{tabular}

The total error in the measurement of NOx concentrations is given by

$$
\left.\Delta N O_{x}\right)_{p p m}=\sqrt{\text { Analyzer_Error }^{2}+\text { Calibration_Error }^{2}+\text { Curvefit_Error }^{2}}
$$




\subsubsection{Power or Energy Error}

The energy is calculated by integrating the brake horsepower over time. The brake horse power is calculated as follows:

$$
b h p-h r=(\text { torque } * r p m) * \frac{2 \pi}{550 * 60}
$$

Therefore the equation that determines the error in the calculation of energy is:

$$
\Delta b h p-h r=\sqrt{\left(\frac{\partial b h p-h r}{\text { ttorque }} * \Delta \text { torque }\right)^{2}+\left(\frac{\partial b h p-h r}{\partial r p m} * \Delta r p m\right)^{2}}
$$

$\Delta$ torque $=$ the error associated with the torque measurements

$\Delta \mathrm{rpm}=$ the error associated with engine speed measurements

By using Equations 7.22-7.24 and Equation 7.10 in Equation 7.5 and 7.7, the uncertainty in the brake specific emissions of $\mathrm{NO}_{\mathrm{x}}$ and $\mathrm{CO}_{2}$ may be calculated.

\subsection{Results and Discussions on Uncertainty in Brake-Specific Emissions}

The flow measurement system employed in MEMS involved measuring several parameters namely absolute pressure, differential pressure, and temperature. Equation 7.6 gives the error associated with the total exhaust mass flow rate. Figure 7.1 shows the exhaust flow rate and the corresponding error in the measurement of the flow rate for an on-road test. It can be noted that for higher flow rates, the error in flow measurement decreases. This can be further illustrated in Figure 7.2. where the error in exhaust flow rate is about $4 \%$ for the exhaust flow rate during engine operation in the NTE zone. Figure 7.3 represents the uncertainty in the calculation of $\mathrm{bsNO}_{\mathrm{x}}$ as a function of total error in exhaust flow rate.

Figure 7.4 shows that the uncertainty in bsNO ${ }_{\mathrm{x}}$ increases almost linearly with an increase in the total error in the measurement of $\mathrm{NO}_{\mathrm{x}}$ concentration values. It is also inferred from Figure 7.4 that the total error in the measurement of $\mathrm{NO}_{\mathrm{x}}$ concentration values for operation in the NTE zone does not exceed $6 \%$.

Figure 7.5 and Figure 7.6 represents the uncertainties in brake-specific emissions of $\mathrm{NO}_{\mathrm{x}}$ and $\mathrm{CO}_{2}$ as a function of engine speed and load. The lug curve for the engine and the boundaries of the NTE zone are also shown. Since bsNO $\mathrm{x}_{\mathrm{x}}$ and $\mathrm{bsCO}_{2}$ were calculated for operation over continuous 30s windows, Figure 7.5 and Figure 7.6 also represent the uncertainty values 
averaged over the same period. Also, it can be seen that the maximum uncertainty in $b_{s N O}$ and $\mathrm{bsCO}_{2}$ generally occur at engine speed $1500 \mathrm{rpm}$.

\subsection{Conclusions}

The uncertainty in the brake-specific emissions of $\mathrm{NO}_{\mathrm{x}}$ and $\mathrm{CO}_{2}$, using the MEMS was found to be less than $10 \%$ and less than $8 \%$, respectively. The analyzers, the exhaust flow rate, pressure transducers, temperature sensors, thermocouples, the flow constant for the Annubar, $\mathrm{K}$ were all considered as sources of error in the uncertainty calculations. A sensitivity analysis on the brake-specific emissions measurements, revealed the sources of uncertainty. It was found that exhaust flow uncertainty, a function of errors in measurement of absolute pressure, differential pressure, Annubar flow coefficient goes up to $12 \%$. But when within the NTE operating zone, the uncertainty is less than $4 \%$ for exhaust flow measurement. This can be seen in Figure 7.1 and Figure 7.2 It can be inferred that the exhaust flow measurement is the major source of uncertainty in the calculation of brake-specific emissions.

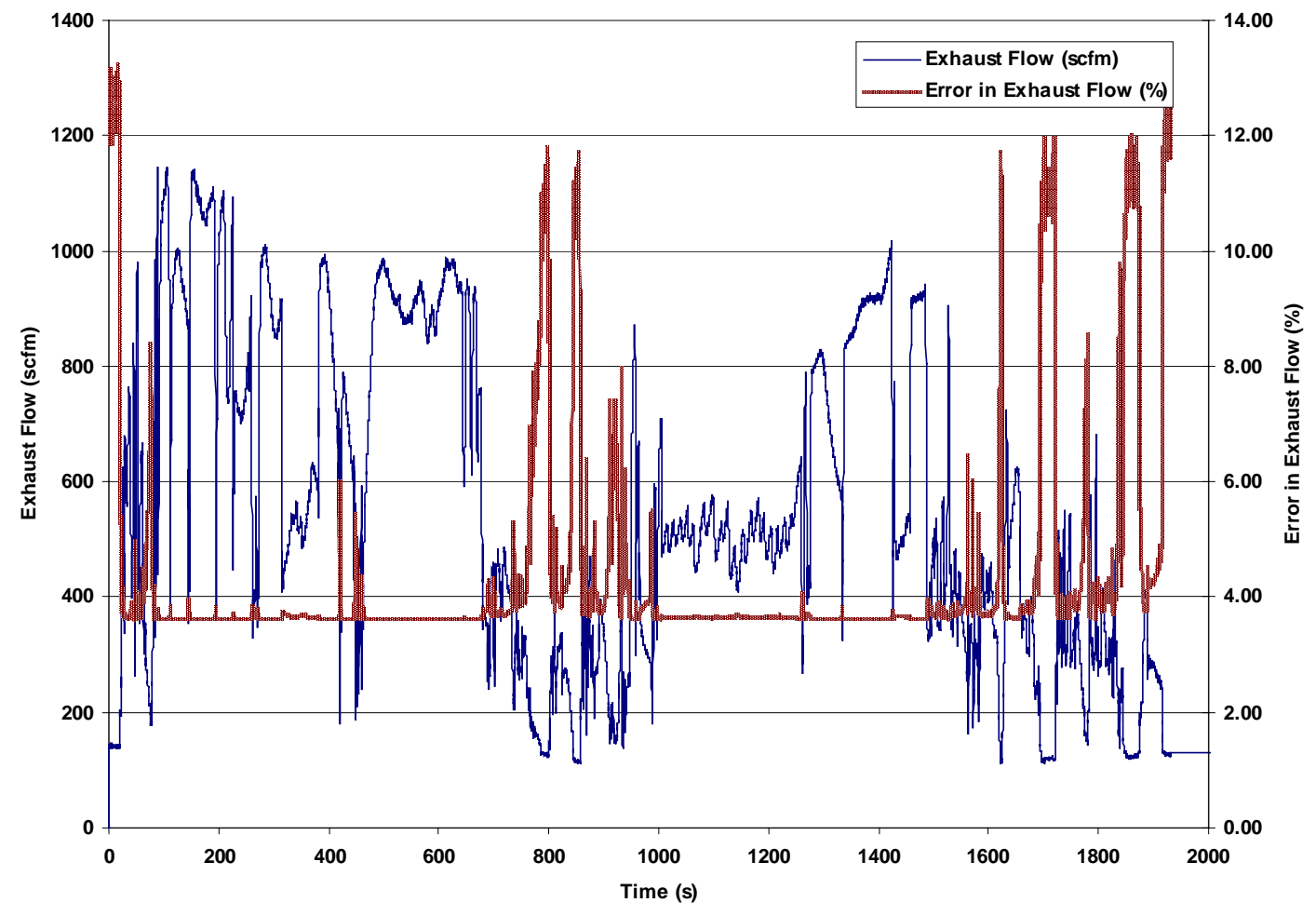

Figure 7.1 Representation of exhaust flow rate and the error in measurement of exhaust flow rate for an on-road test. 


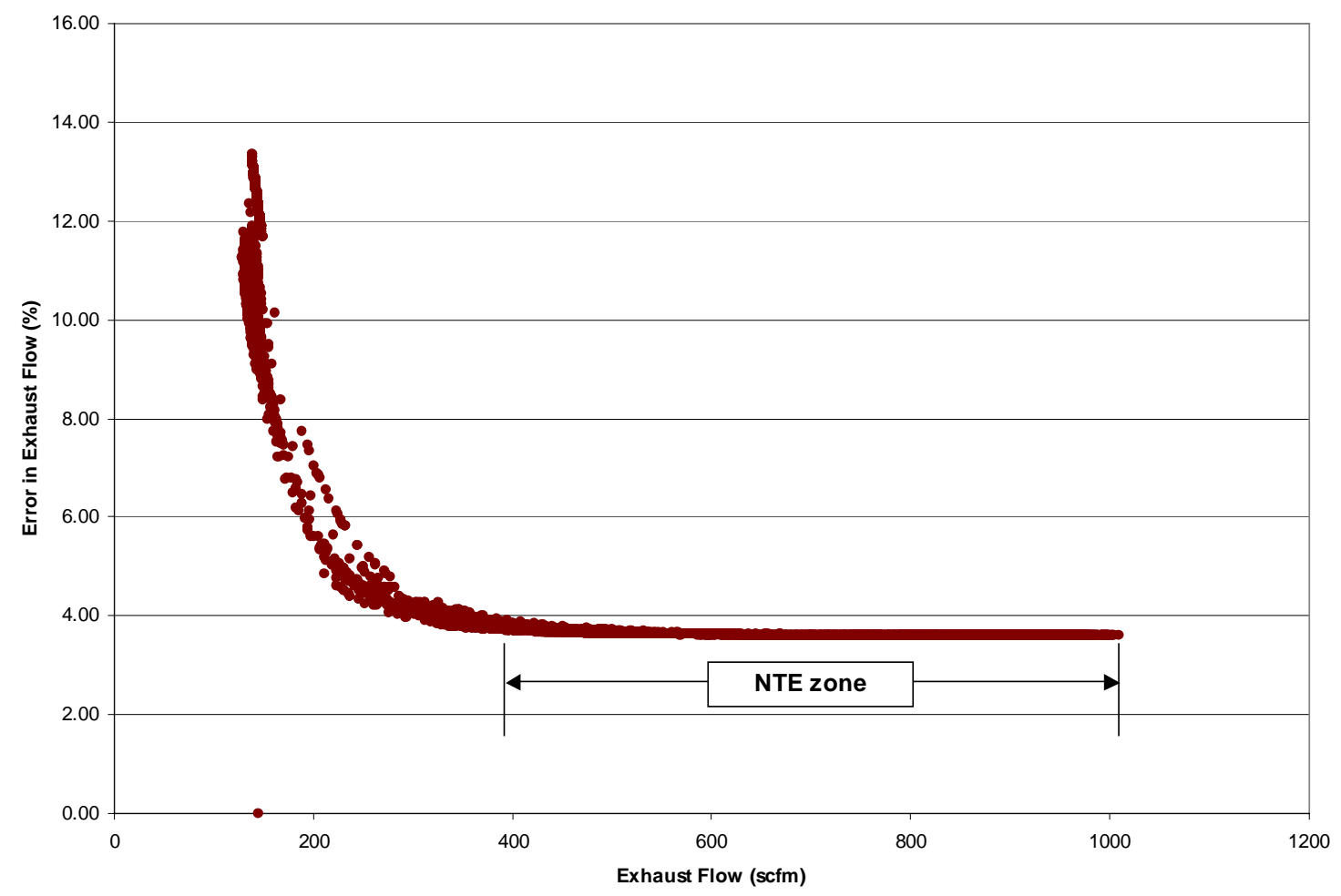

Figure 7.2 Effect of flow rate on the error in exhaust flow measurement.

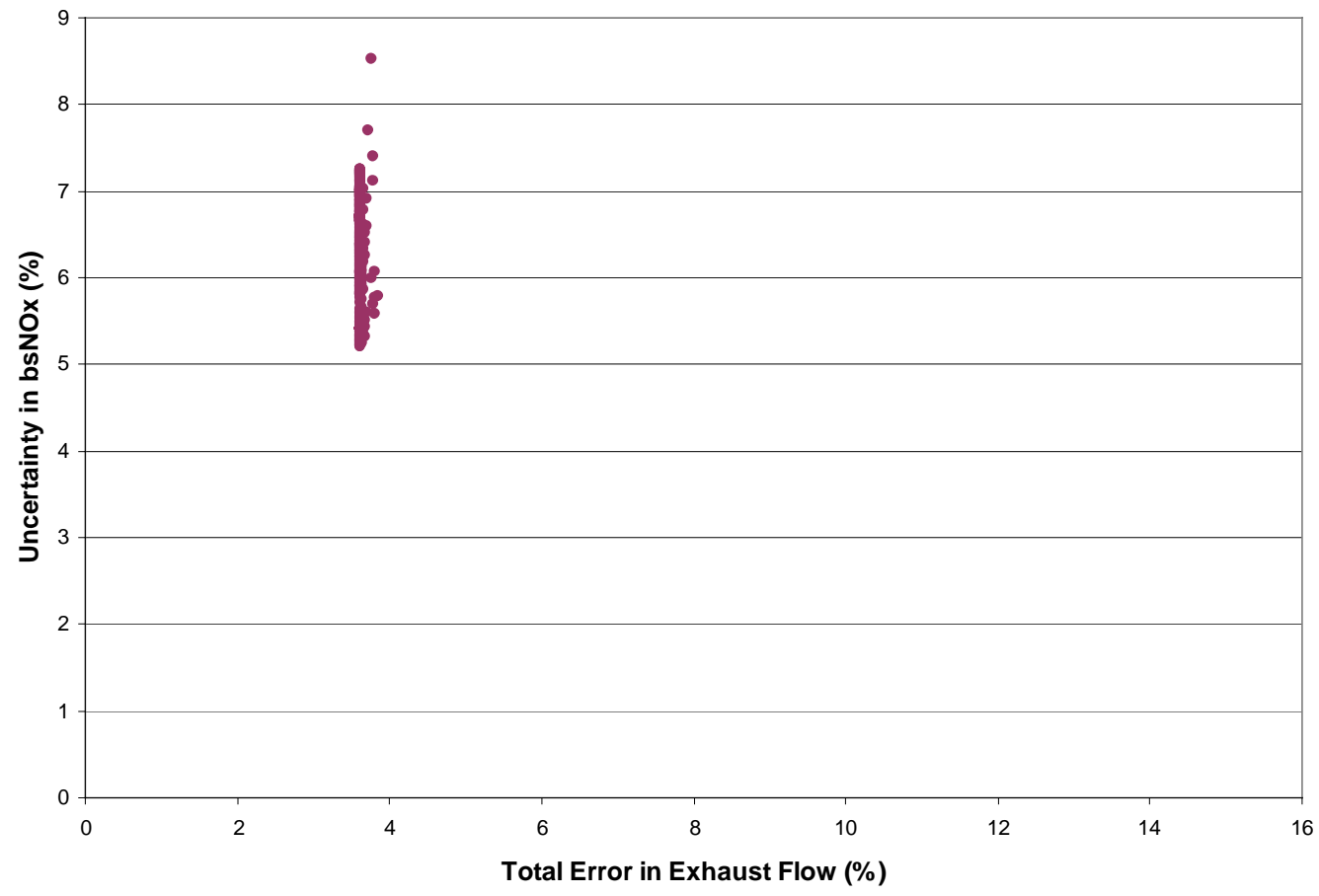

Figure 7.3 Effect of errors in exhaust flow measurement within the NTE region on brake-specific $\mathrm{NO}_{\mathrm{x}}$ uncertainty. 


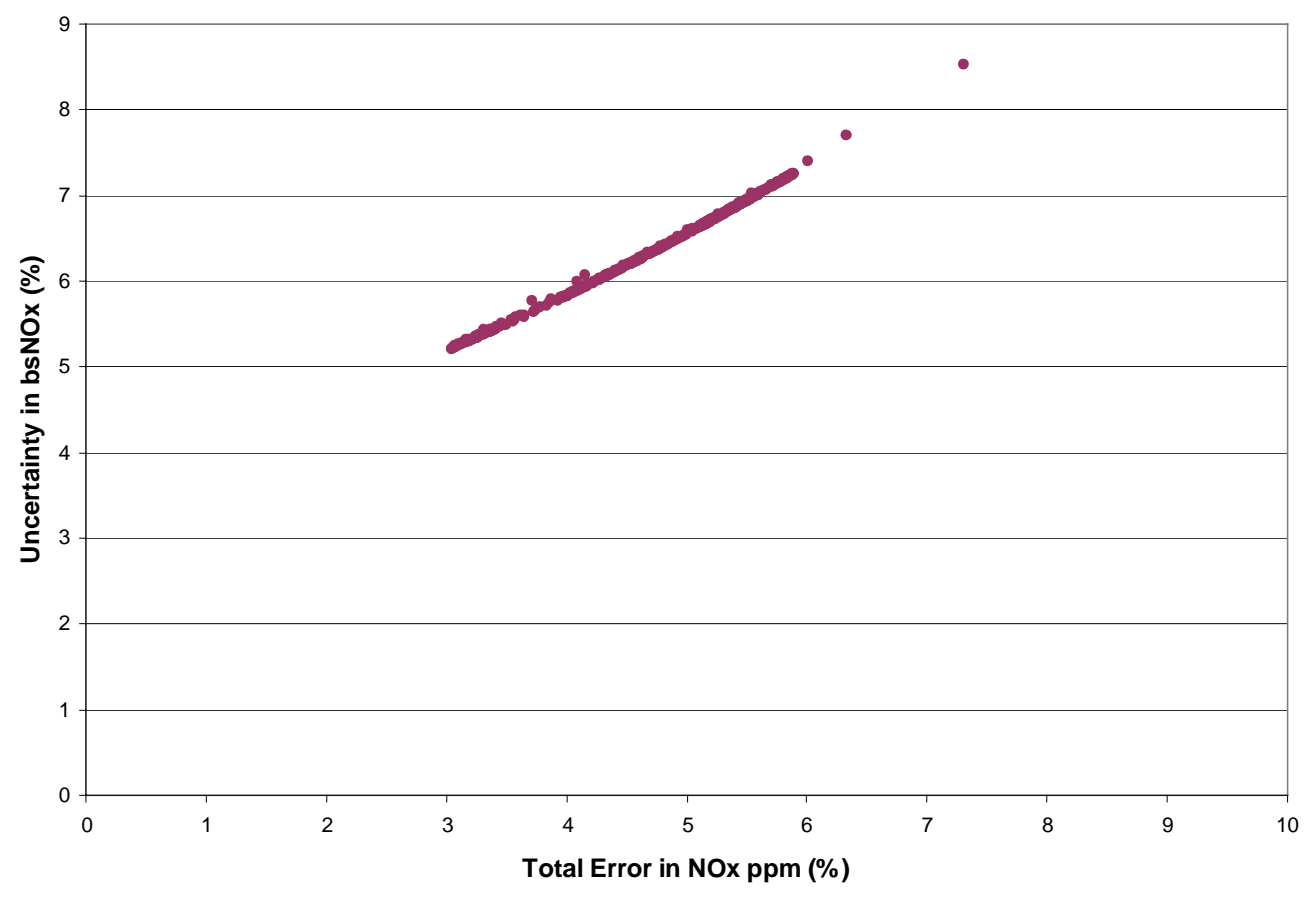

Figure 7.4 Effect of errors in $\mathrm{NO}_{\mathrm{x}} \mathrm{ppm}$ on $\mathrm{bsNO}_{\mathrm{x}}$ uncertainty.

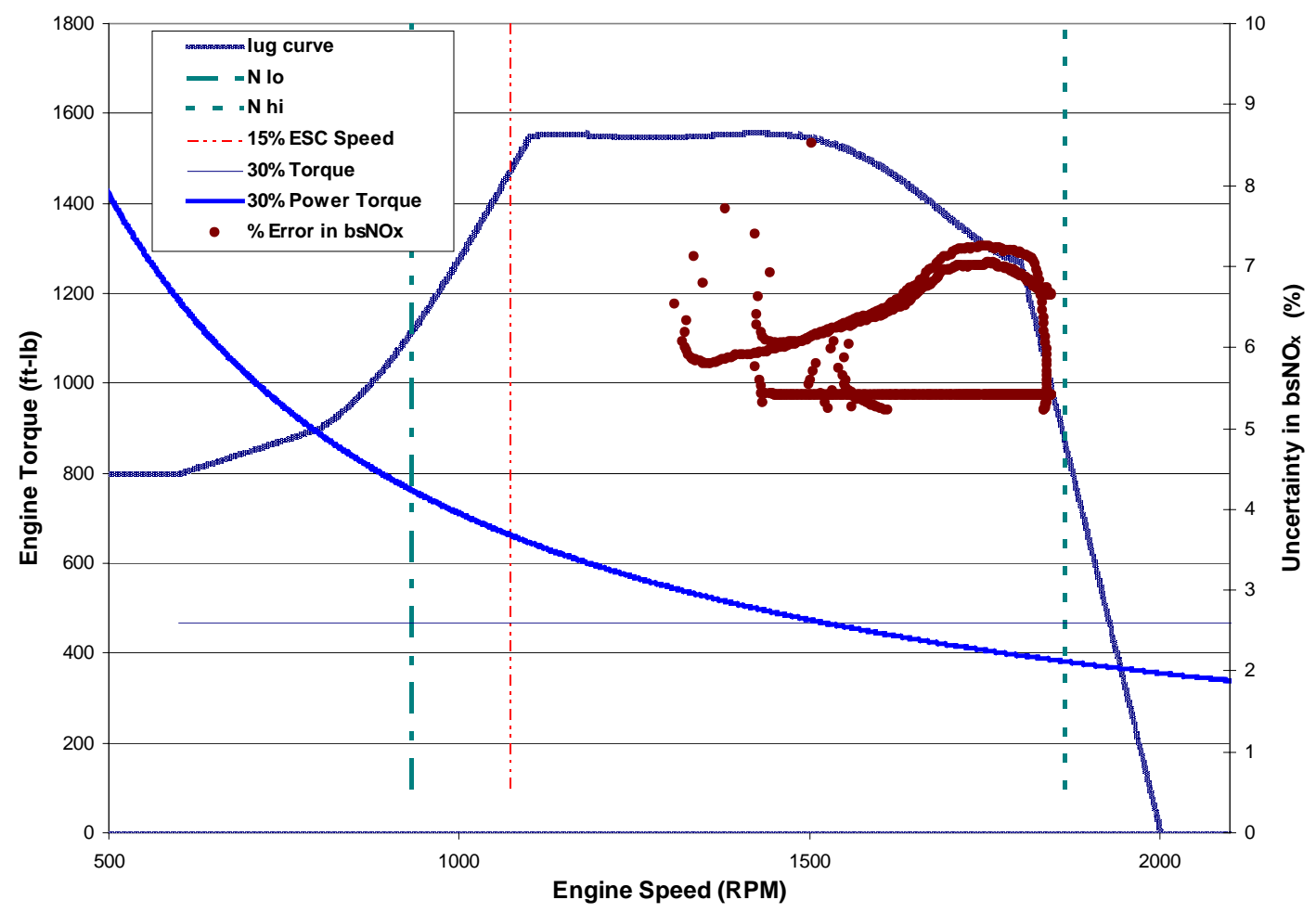

Figure 7.5 Representation of error in $\mathrm{bsNO}_{\mathrm{x}}$ emissions on an engine speed vs. engine load curve. 


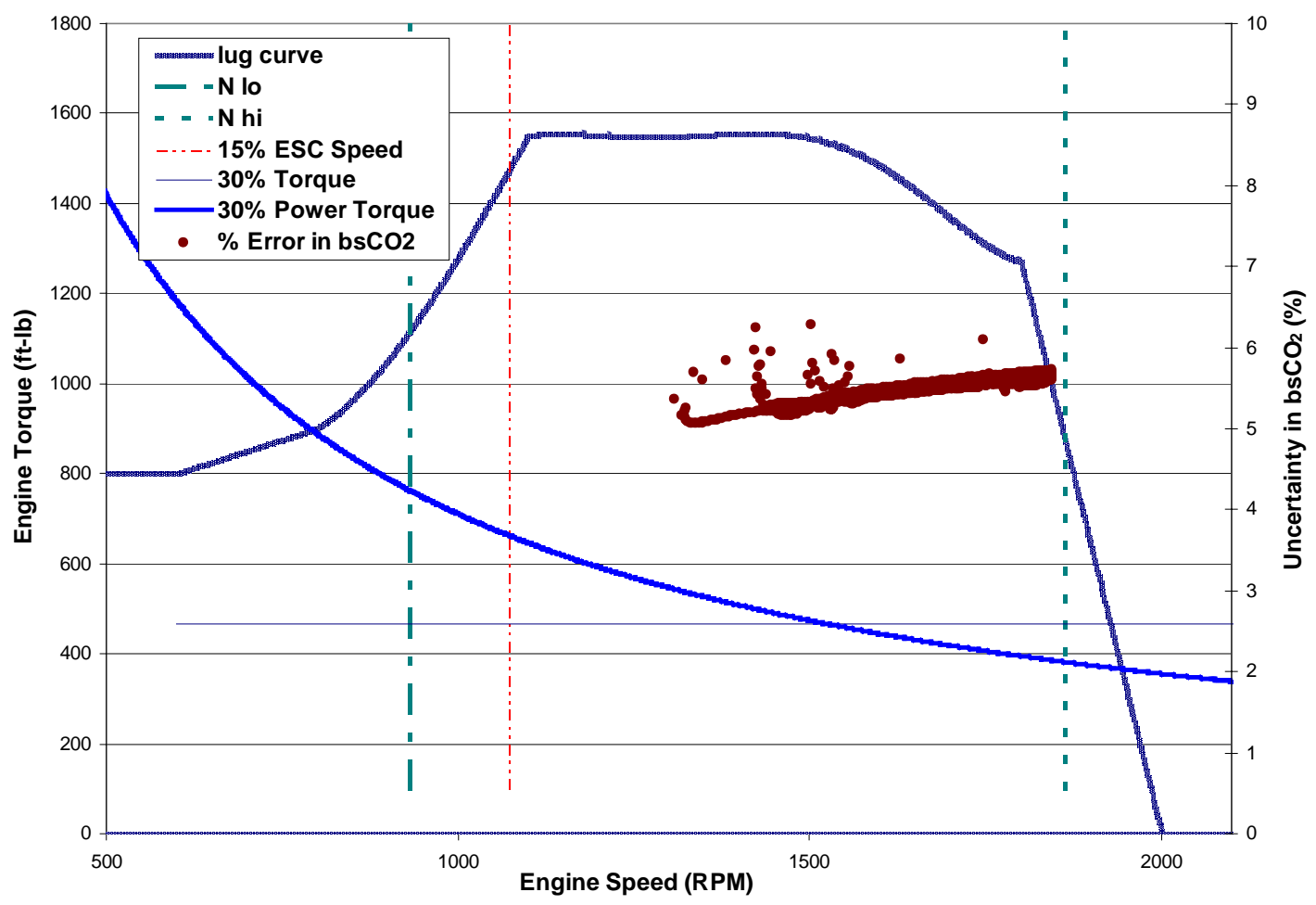

Figure 7.6 Representation of error in $\mathrm{bsCO}_{2}$ emissions on an engine speed vs. engine load curve. 


\section{RESULTS AND DISCUSSIONS}

All vehicles were tested on three different routes as mentioned earlier in Chapter 5 The brake-specific emissions from these engines were influenced by various operating parameters such as engine speed and load. Also, the ambient conditions such as, the relative humidity, barometric pressure and ambient temperature were factors that influenced emissions. Since these tests were performed on-road, there was little or no control over these parameters. The variation of emissions from these routes can be attributed to differences in the driving patterns followed on each route.

Two sets of analyses were performed on the on-road data. The first set of analysis focused on characterization of the episodic nature of vehicle emissions. The on-road microscale measurements of vehicle emissions help in representing the influence of real-world driving. Vehicle emissions are often influenced by short-term events. These events could be either a period of acceleration, deceleration or cruise.

The second set of analysis was done to characterize the operating region of the engines for the different routes. Individual operating parameters such as engine speed, engine torque, vehicle speed, and engine power were considered, and the behavior of NTE emissions was studied. The most notable results obtained from these on-road tests are discussed in the following sections.

In order to reduce the uncertainties in the measurement of brake-specific emissions from the MEMS, an attempt has been made to report emissions based on the $\mathrm{NO}_{\mathrm{x}} / \mathrm{CO}_{2}$ ratio. The use of the $\mathrm{NO}_{\mathrm{x}} / \mathrm{CO}_{2}$ ratio for the fuel specific $\mathrm{NO}_{\mathrm{x}}$ emissions eliminates the uncertainties introduced by the ECU-broadcast torque and measured exhaust flow rate values. Additionally, a 'baseline factor' was developed, which could serve as a means to check if the emissions within the NTE limits are in compliance with the in-use brake-specific emissions requirements of the Consent Decrees. This factor is independent of exhaust flow rates and engine torque broadcast values.

\subsection{Representation of Time Traces and Emissions Episodes}

The two main objectives of this analysis were: (1) to characterize the episodic nature of events during each of the selected routes; and (2) to compare emissions based on different routes. The data presented in this study were results from the on-road test of a Class 8 Tractor, with the MY 1996 engine rated at $435 \mathrm{hp}$ and $1550 \mathrm{ft}-\mathrm{lb}$ at $1700 \mathrm{rpm}$. The following paragraphs describe 
about the micro-scale variations in vehicle speed, engine speed and engine load that occurs in each of the routes described in Chapter 5 .

\subsubsection{SAB2BM}

The time traces of vehicle speed, engine speed and engine load for the Sabraton to Bruceton route are given in Figure 8.1 The instantaneous speed ranged from 1 to approximately $70 \mathrm{mph}$, and the average speed was $40 \mathrm{mph}$. The maximum time that the engine spends in the NTE zone was during the hill climb starting at Cheat Lake ending at Cooper's Rock, with the altitude changing from approximately 800 feet to 2250 feet as shown in Figure 8.2 The distance the vehicle covers during the uphill is approximately 5 miles. It can be noted that the vehicle speed drops drastically during that period, with the average speed being $25 \mathrm{mph}$. The load factor for the route was found to be 0.54 . While operating in the NTE zone the load factor was 0.92 and slightly higher during continuous 30s windows with the value reaching 0.96 .

\subsubsection{BM2SAB}

On the return journey on the Bruceton Mills route, the average vehicle speed is was 40 $\mathrm{mph}$, with the maximum of approximately $70 \mathrm{mph}$. The maximum vehicle speed is encountered when the vehicle starts descending the hill from Coopers Rock up to Cheat Lake as shown in Figure 8.4. The road grade during downhill is 5\% as shown in Figure 8.3. But this region does not contribute to the NTE operation, mostly because the engine operates close to no load condition. The longest possible NTE operation occurs when the vehicle ascends up to the Coopers Rock mandatory truck stop. For the entire route the average load factor was 0.38 and in the NTE zone it was 0.90 and 0.95 during operation over continuous 30 s widows.

\subsubsection{PA1}

This route actually represents city-driving pattern. The average and maximum vehicle speeds during this route were $30 \mathrm{mph}$ and $50 \mathrm{mph}$, respectively as shown in Figure 8.5 The altitude does not vary very much for the entire route. The load factor for this route was the least at 0.30 . For operation in the NTE zone and 30s windows it was 0.83 and 0.95 respectively.

\subsubsection{PA2}

This route is a mix of both city and highway driving. The route can actually be divided into two parts. The first part represents the city or suburban driving, while the other part represents highway-driving patterns. It can be noted that the average speed during the first part of the route was $30 \mathrm{mph}$ and during the highway driving it was $60 \mathrm{mph}$ as illustrated in Figure 8.6. The average speed for the entire route was $40 \mathrm{mph}$ and the maximum speed was about $70 \mathrm{mph}$. 
The average load factor for the entire route was 0.33 and 0.80 during NTE operation. The load factor averaged for operation in the NTE zone over a 30s window was 0.93 .

\subsubsection{PA3}

This route is a "highway route" that was driven only on the interstate I-79 as described earlier in Chapter 5. The average speed on this route was $60 \mathrm{mph}$ as shown in Figure 8.7. The load factor for operation in the NTE zone was 0.85 and 0.96 over 30 s windows. The average load factor for the entire route was highest among the three legs of the Pittsburgh route and was found to be 0.42 .

\subsubsection{SAB2SW}

On the outward journey, except for the starting period from Sabraton test facility to the ramp that connects to I-79, the vehicle speed was approximately $40 \mathrm{mph}$. The maximum variation in altitude was encountered during the route was about $500 \mathrm{ft}$ over a distance of 5 miles, when the vehicle ascends from an altitude of $750 \mathrm{ft}$ to about $1250 \mathrm{ft}$ as illustrated in Figure 8.9. The average and maximum vehicle speeds during the route were $50 \mathrm{mph}$ and $70 \mathrm{mph}$ respectively as shown in Figure 8.8. The load factors average for the entire route, NTE operation, continuous 30s NTE operation were $0.59,0.92,0.97$ respectively.

\subsubsection{SW2SAB}

The return journey was very similar to the outbound journey with only very slight changes in average and maximum speed as shown in Figure 8.11. Also the load factors were similar. The load factors average for the entire route, NTE operation, continuous 30s NTE operation were $0.52,0.93,0.95$ respectively.

The summary of load factors encountered on each route during operation in the NTE zone and during operation over continuous 30 s windows and also for the entire route is given in Table 8-1

Table 8-1 Summary of load factor for different routes on a MY1997 engine

\begin{tabular}{||c|c|c|c|}
\hline Route/Leg & Total Route & Total NTE Zone & 30s windows \\
\hline SAB2BM & 0.54 & 0.93 & 0.96 \\
\hline BM2SAB & 0.38 & 0.90 & 0.95 \\
\hline PA1 & 0.33 & 0.83 & 0.95 \\
\hline PA2 & 0.33 & 0.80 & 0.93 \\
\hline PA3 & 0.42 & 0.85 & 0.96 \\
\hline SAB2SW & 0.59 & 0.92 & 0.97 \\
\hline SW2SAB & 0.52 & 0.93 & 0.96 \\
\hline
\end{tabular}



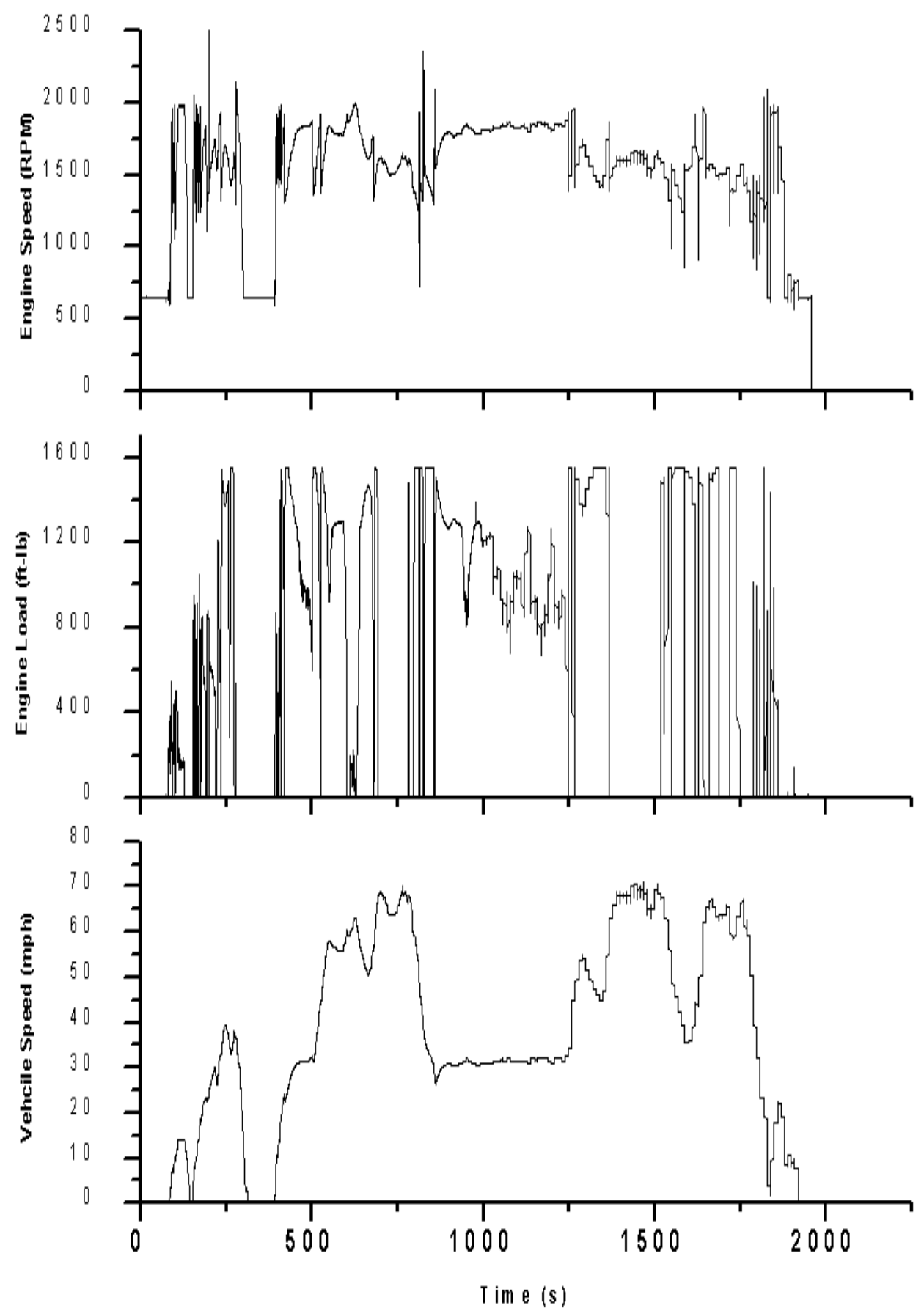

Figure 8.1 Time traces of vehicle speed, engine load, and engine speed for a SAB2BM route. 


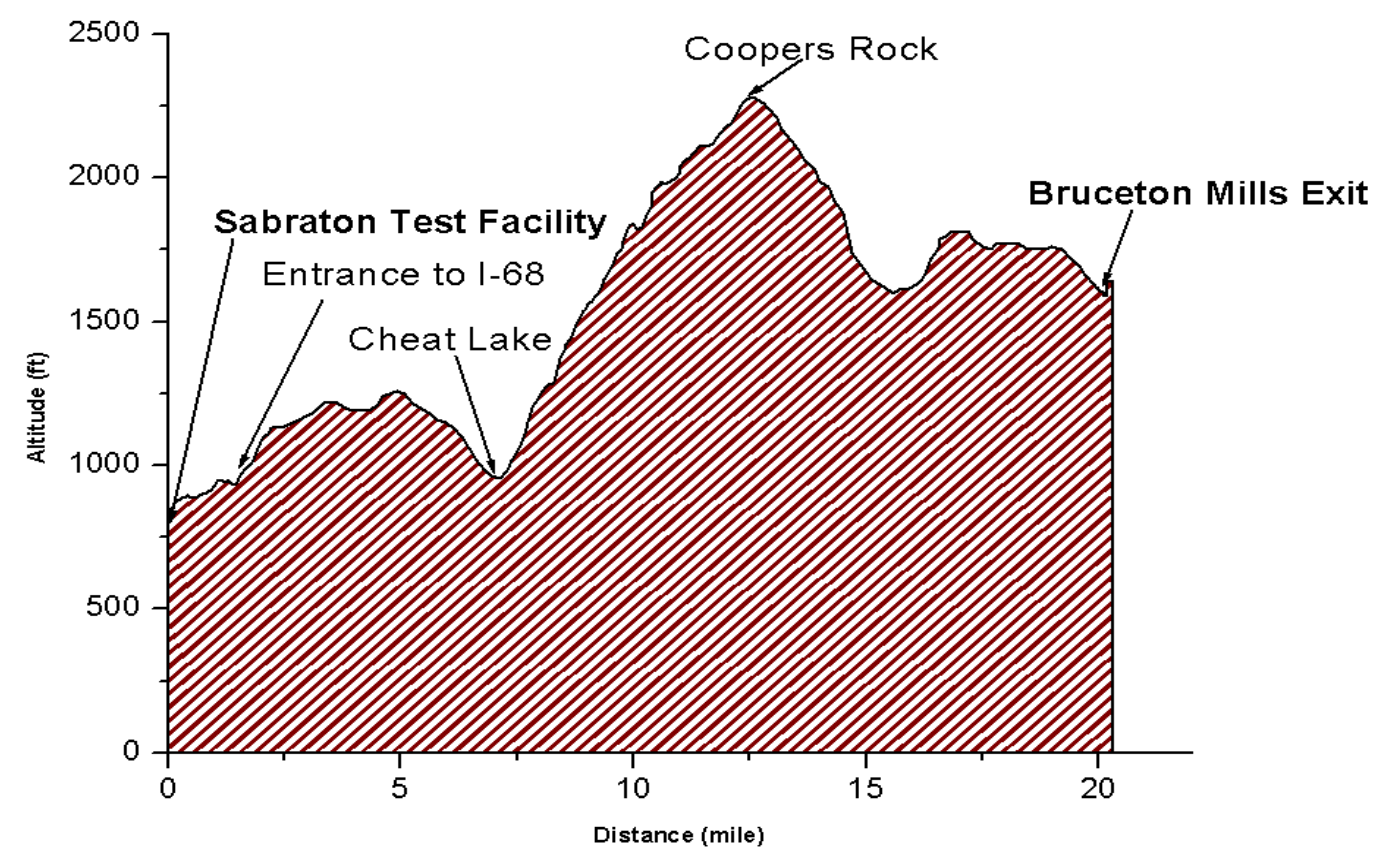

Figure 8.2 Altitude profile for the SAB2BM route

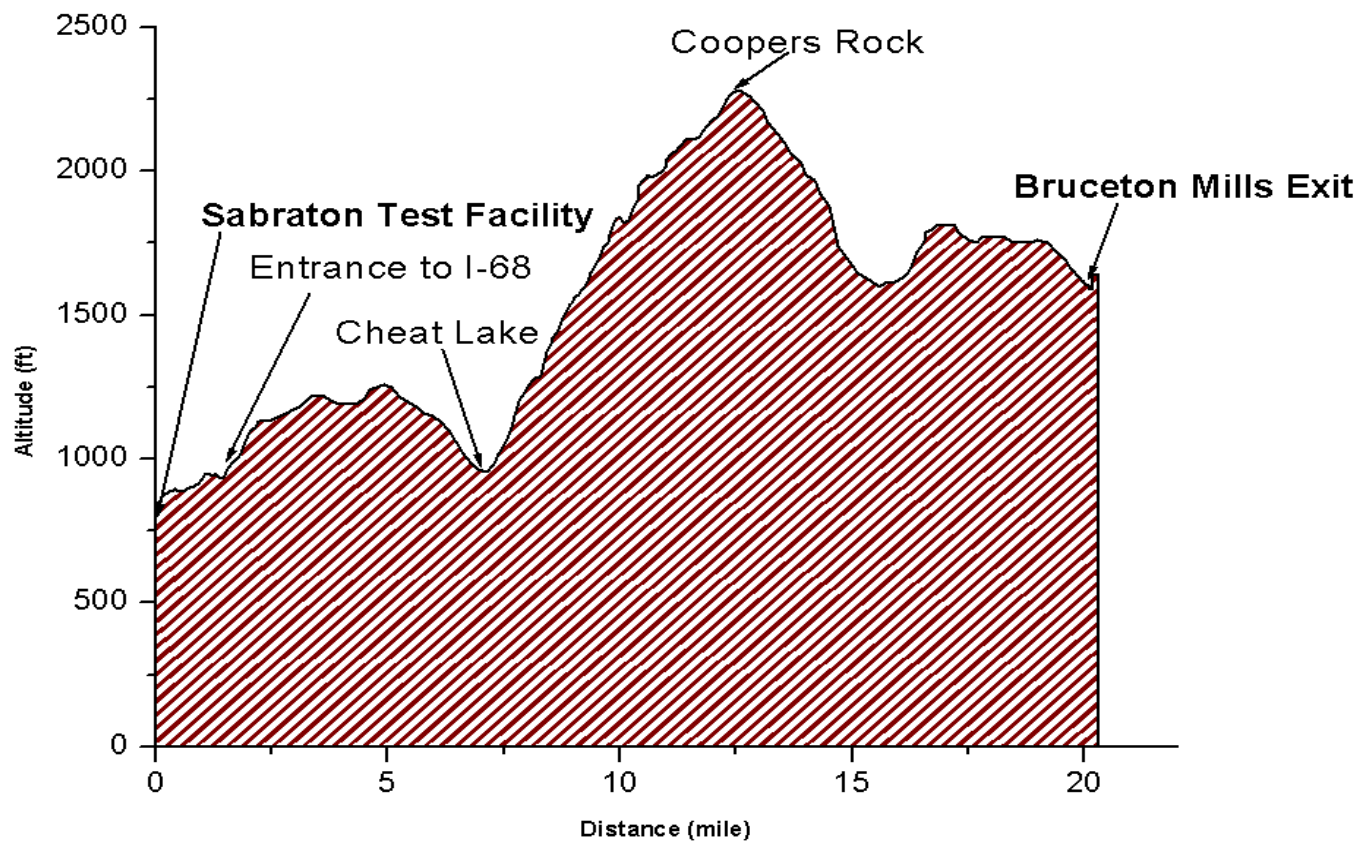

Figure 8.3 Altitude profile for the BM2SAB route 

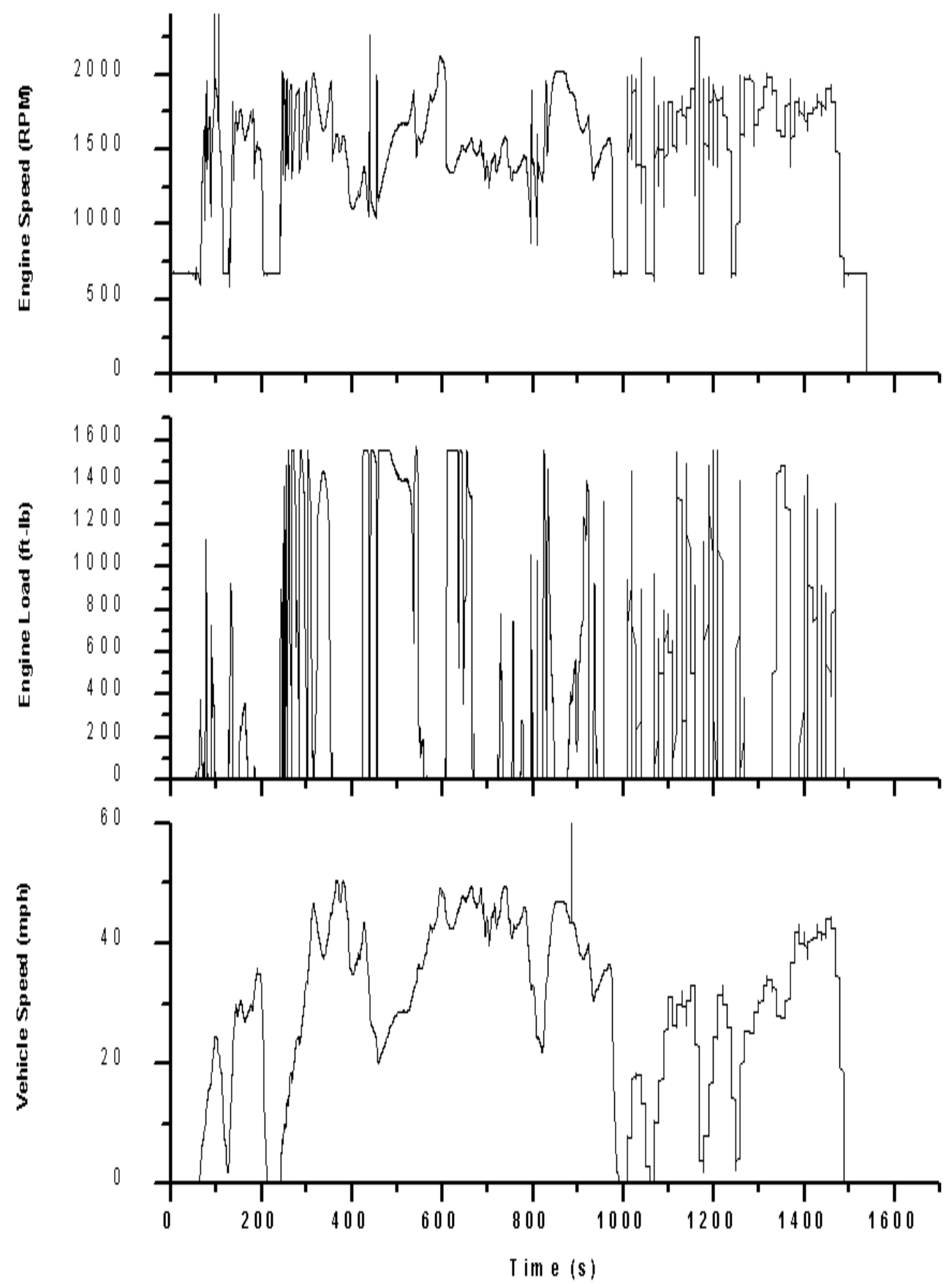

Figure 8.4 Time traces of vehicle speed, engine load, and engine speed for a BM2SAB route. 

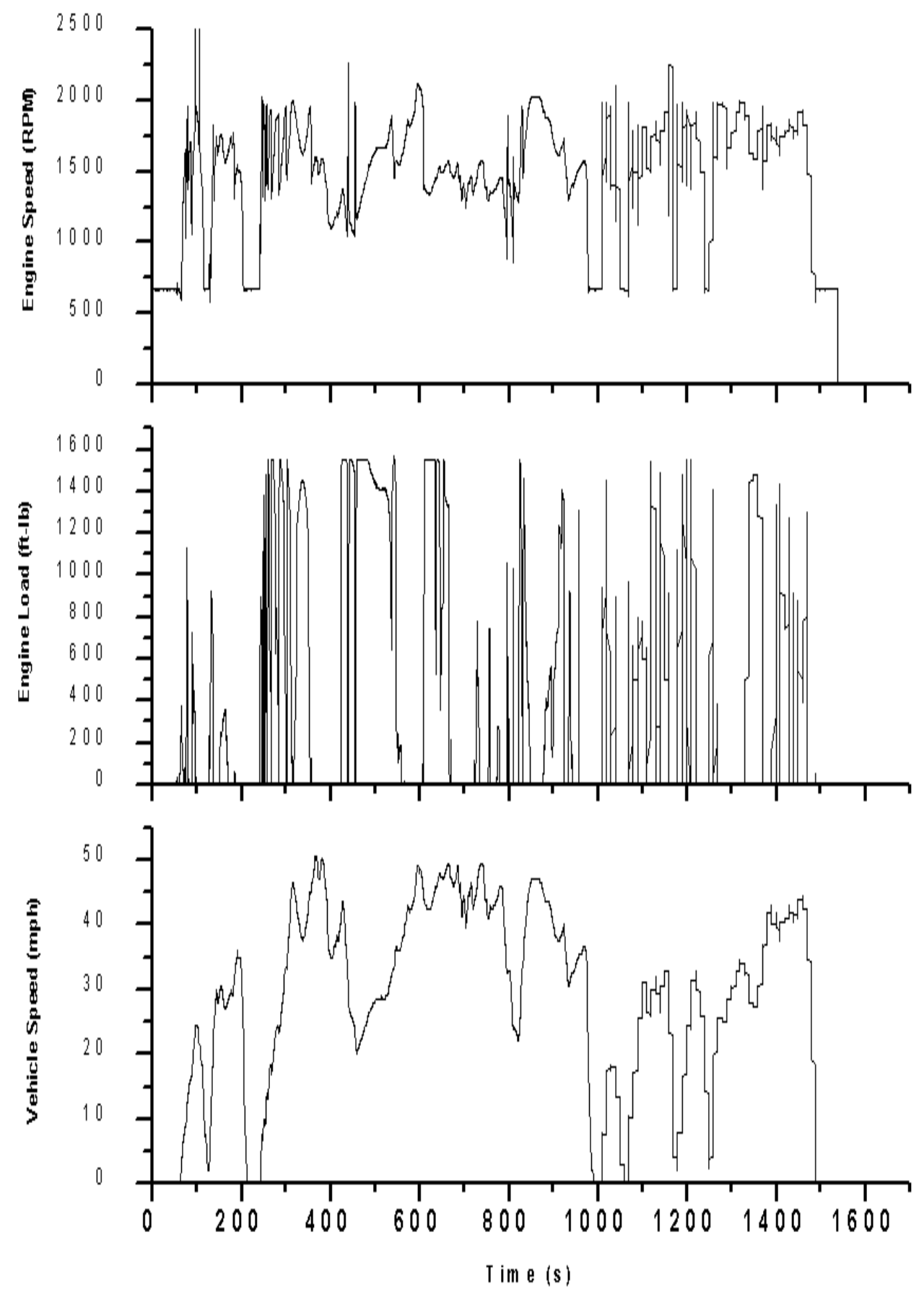

Figure 8.5 Time traces of vehicle speed, engine load, and engine speed for a PA1 route. 

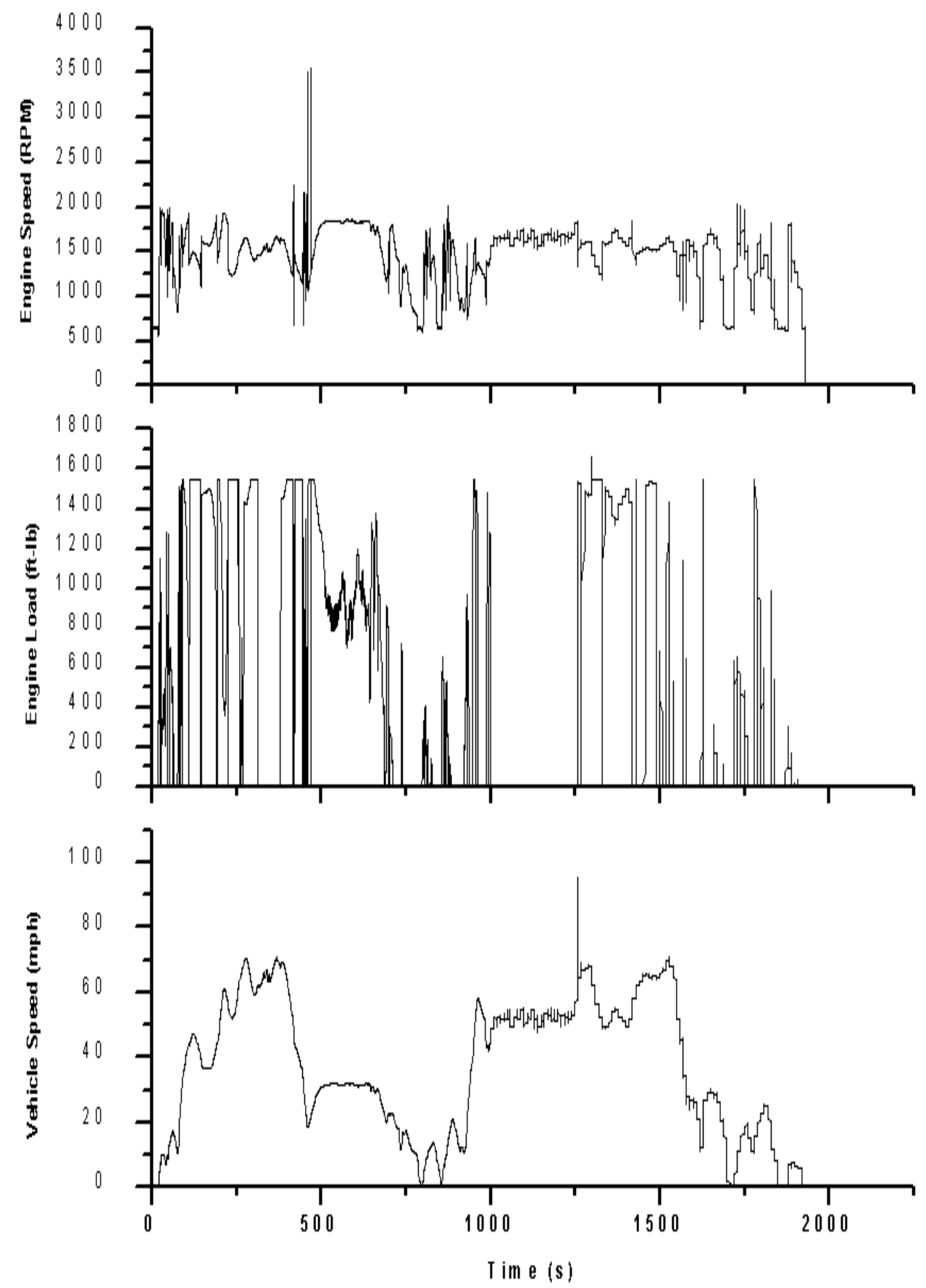

Figure 8.6 Time traces of vehicle speed, engine load, and engine speed for a PA2 route. 

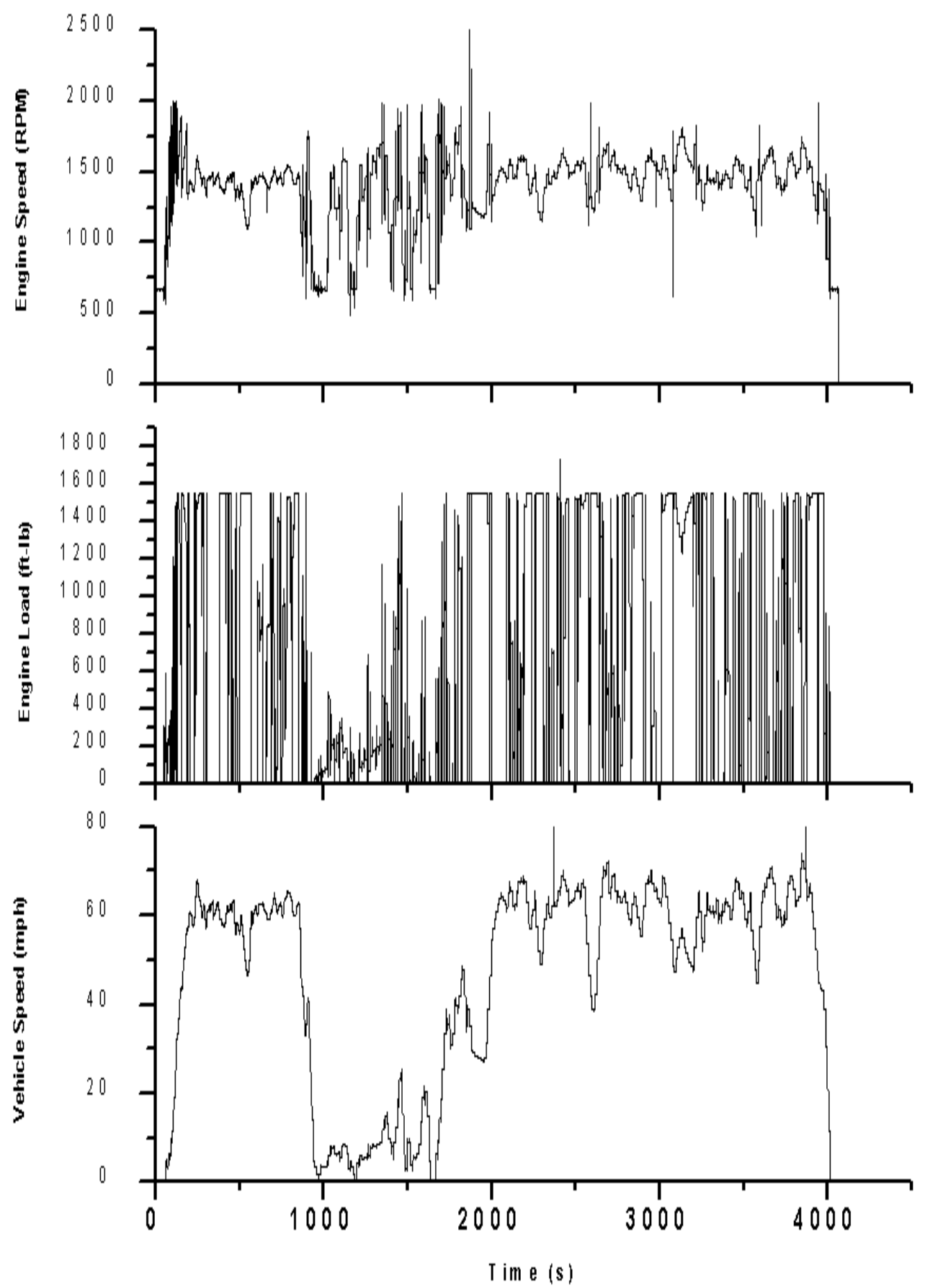

Figure 8.7 Time traces of vehicle speed, engine load, and engine speed for a PA3 route. 

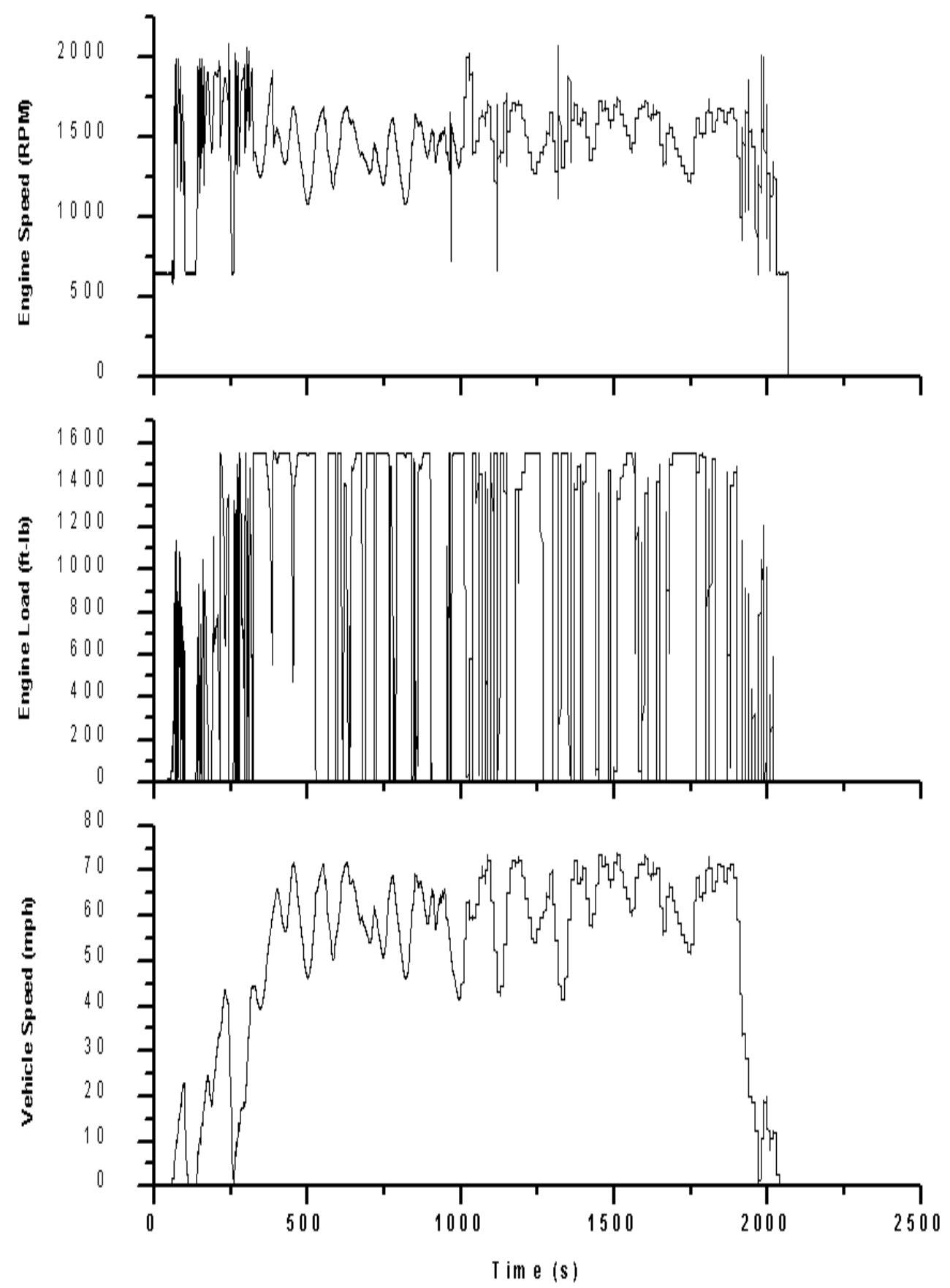

Figure 8.8 Time traces of vehicle speed, engine load, and engine speed for a SAB2SW route. 


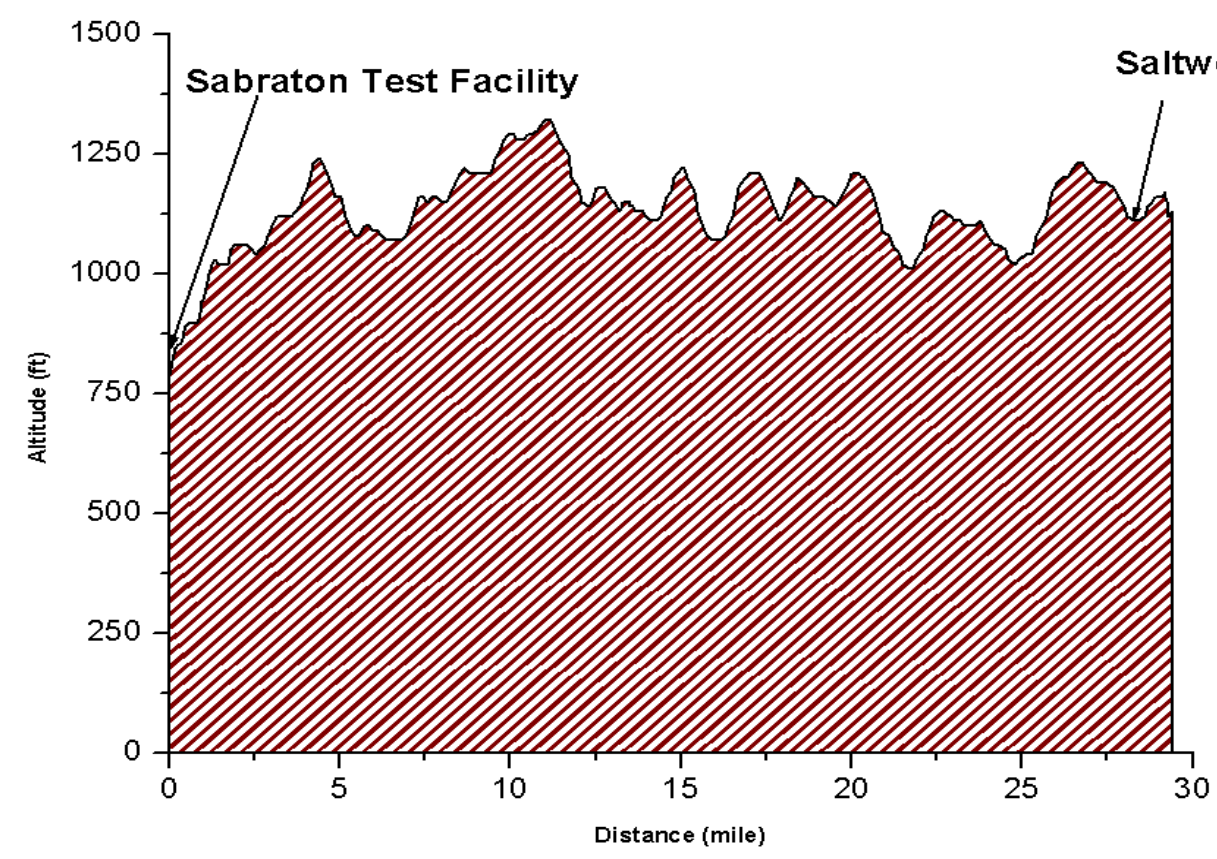

Figure 8.9 Altitude profile for the SAB2SW route

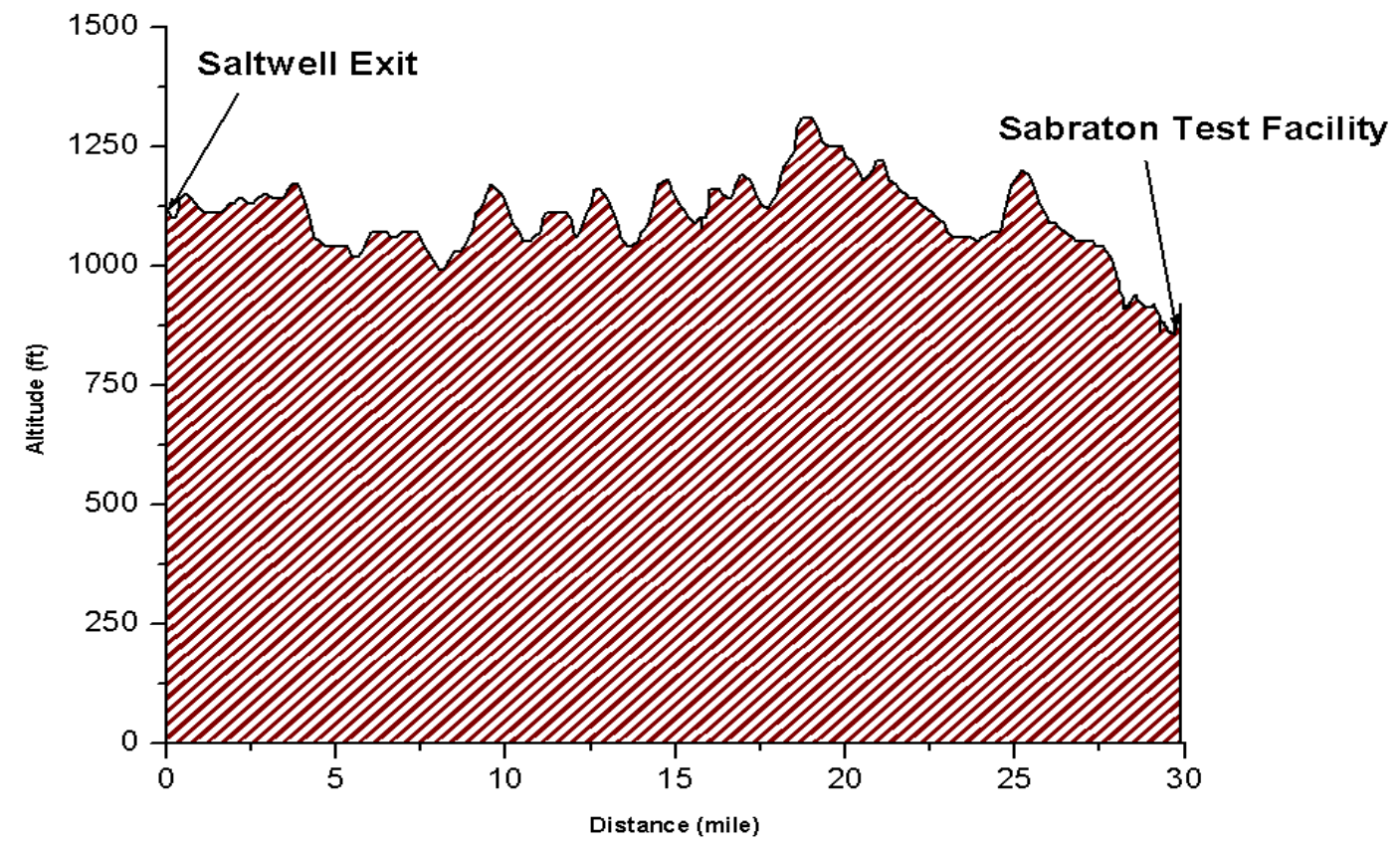

Figure 8.10 Altitude profile for the SW2SAB route. 

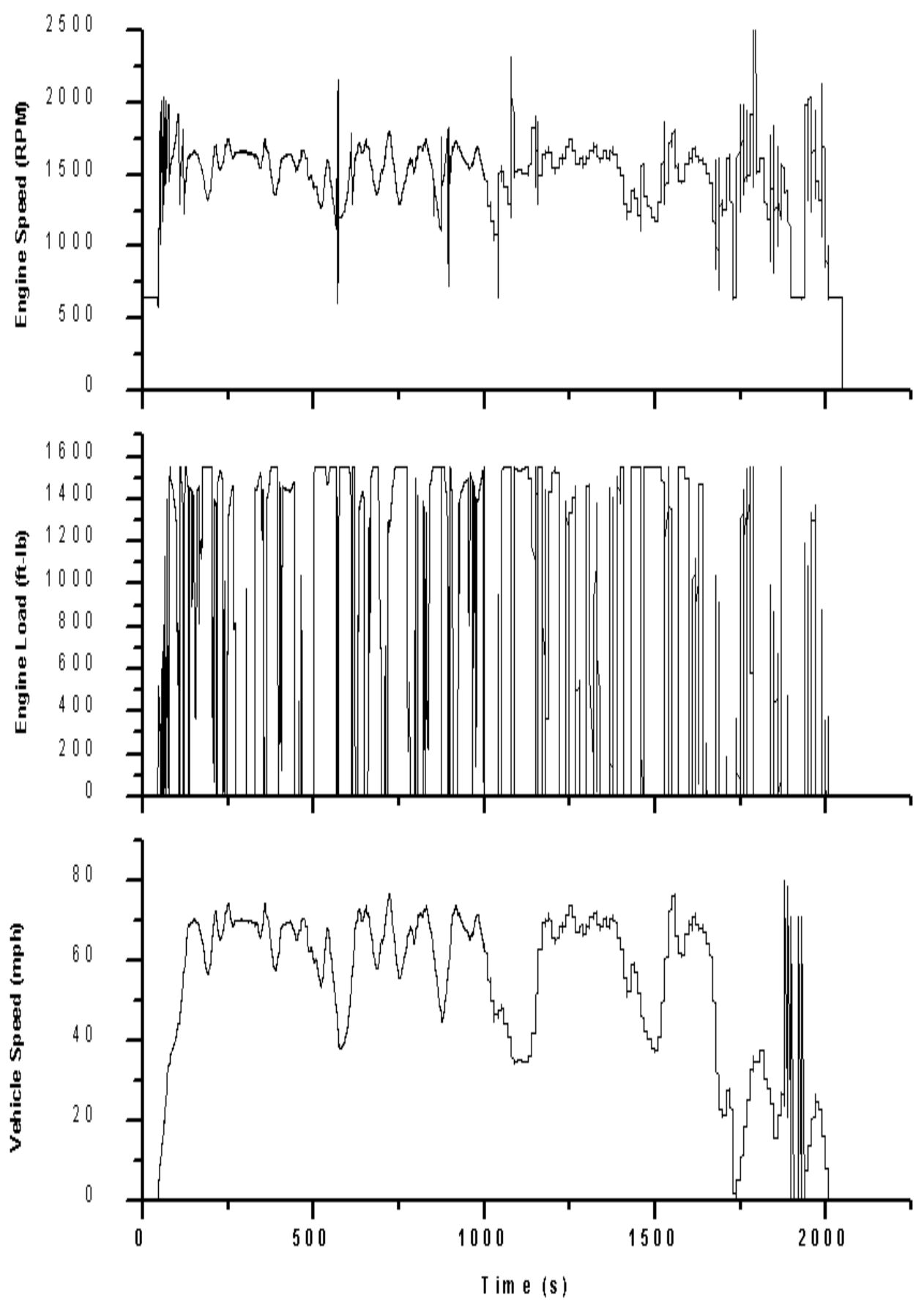

Figure 8.11 Time traces of vehicle speed, engine load, and engine speed for a SW2SAB route. 


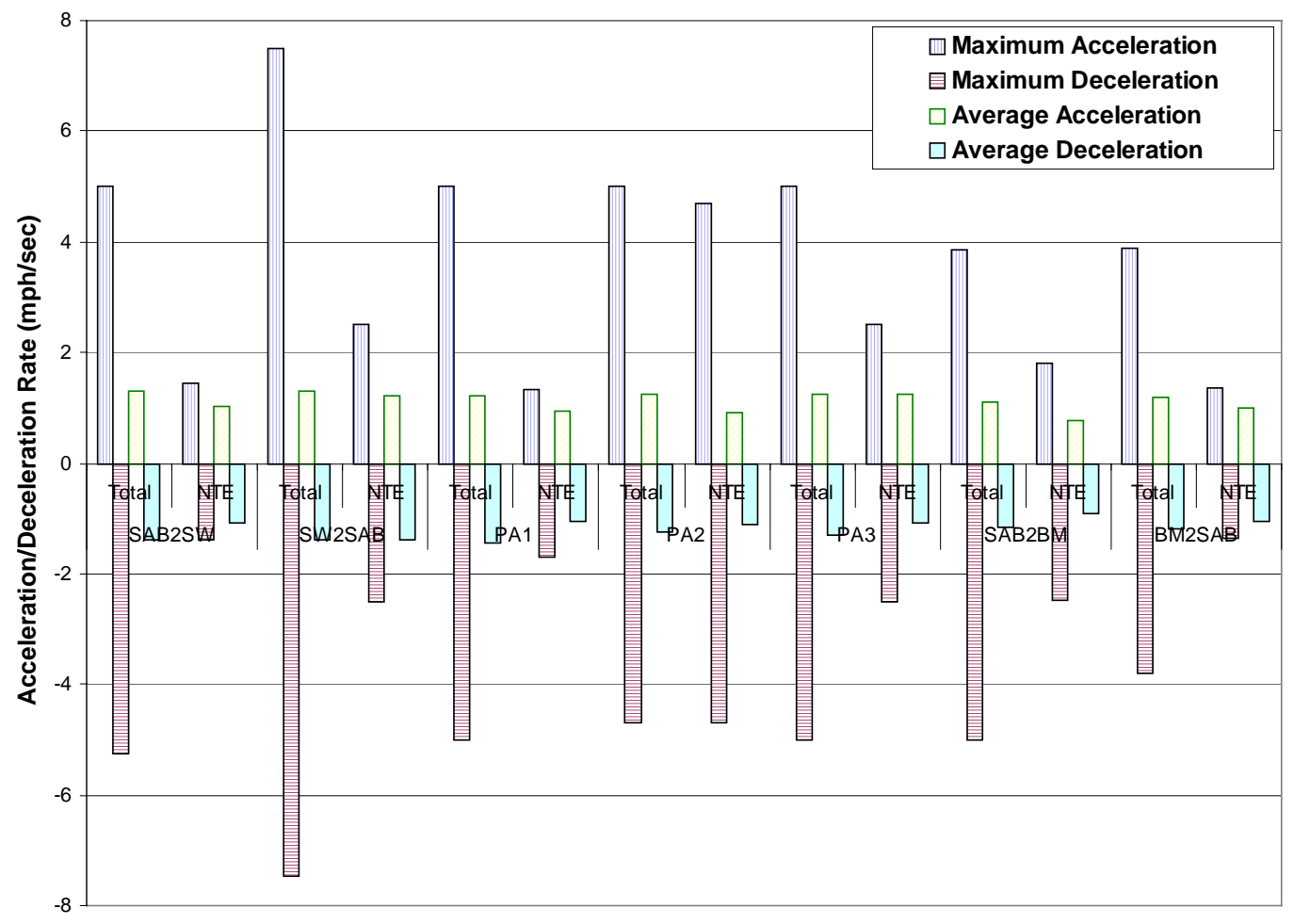

Figure 8.12 Acceleration and deceleration rates both in the NTE and non-NTE regions.

The maximum, minimum and average acceleration rates for the entire route and also within the NTE region are shown in Figure 8.12 from on-road tests of a Class 8 Tractor, with the MY 1996 engine rated at $435 \mathrm{hp}$ and $1550 \mathrm{ft}-\mathrm{lb}$ at $1700 \mathrm{rpm}$. For a SAB2BM route the maximum acceleration was $3.85 \mathrm{mph} / \mathrm{sec}$, while the maximum acceleration in the NTE region was at 1.82 $\mathrm{mph} / \mathrm{sec}$. The maximum deceleration was found to be $5 \mathrm{mph} / \mathrm{sec}$ and $0.49 \mathrm{mph} / \mathrm{sec}$ within the NTE region. The average acceleration and deceleration were $1.14 \mathrm{mph} / \mathrm{sec}$ and $1.16 \mathrm{mph} / \mathrm{sec}$ and within the NTE region it was $0.78 \mathrm{mph} / \mathrm{sec}$ and $0.9 \mathrm{mph} / \mathrm{sec}$ respectively. For the BM2SAB route the maximum and average acceleration in the NTE zone is $1.37 \mathrm{mph} / \mathrm{sec}$ and $0.99 \mathrm{mph} / \mathrm{sec}$. The deceleration had a maximum value of $1.37 \mathrm{mph} / \mathrm{sec}$ and an average value of $1.05 \mathrm{mph} / \mathrm{sec}$. Similarly the trends in acceleration and deceleration for different routes can be seen from the same Figure 8.12 It can be noted that the SW2SAB route had the highest acceleration and deceleration rate at $7.49 \mathrm{mph} / \mathrm{sec}$ and $7.49 \mathrm{mph} / \mathrm{sec}$, respectively. However in the NTE zone it accelerates at $2.5 \mathrm{mph} / \mathrm{sec}$ and decelerates at $2.5 \mathrm{mph} / \mathrm{sec}$.

\subsection{Modal Emissions Analysis Results}

The analysis of on-road emissions with respect to driving modes, also referred to as modal emissions, has been reported in several published studies [40,7]. But most of these studies 
have employed chassis dynamometer data for analysis. In this work, the NTE emissions data were divided into four modes namely idle, acceleration, deceleration and cruise, and average emissions rates for each mode were calculated.

The idle mode was defined as zero speed and zero acceleration. For acceleration mode, the vehicle speed must be greater than zero. Deceleration is defined in a similar manner as acceleration, except that the criteria for deceleration are based on negative acceleration. All other events not classified as idle, acceleration, or deceleration was classified as cruise. The cruise mode was approximately steady-speed driving, but some variation of speed was allowed.

It can be seen from the Figure 8.13 that among the four modes, the idle mode did not contribute to operation in NTE region. Hence, it was not considered in the analysis. The acceleration, deceleration, cruise modes may contribute to the NTE operation, and hence, the emissions analysis was focused on only these three modes.

One of the key objectives of this study was to understand the variability in emissions from the different routes. The routes were selected to represent different driving such as city driving, non-highway and highway driving. Hence the emission rates were expected to differ among routes. Also, factors such as time of day and direction of travel, average speed, ambient temperature and relative humidity were found to be significant is most of the cases. With the exception of Bruceton Mills route, no significant relationship between emissions and road grade was found, since the road grade on the other routes were not steep or not long enough to be important. The following sections discuss the effect of each of the modes from the different routes that were used for the test program.

Figure 8.13 shows the brake-specific emissions of $\mathrm{NO}_{\mathrm{x}}$ and $\mathrm{CO}_{2}$ along the entire route of the cycle for the SAB2BM route. Also Figure 8.13 shows regions of acceleration, cruise and deceleration within the NTE zone and their contribution to emissions. It can be seen that the emission rates of $\mathrm{NO}_{\mathrm{x}}$ were the highest during the cruise mode. The acceleration mode has higher $\mathrm{NO}_{\mathrm{x}}$ emission rates when compared to the deceleration mode. The cruise operation here represents the climbing of the hill from Coopers Rock with the engine operating at full load and at rated speed. 

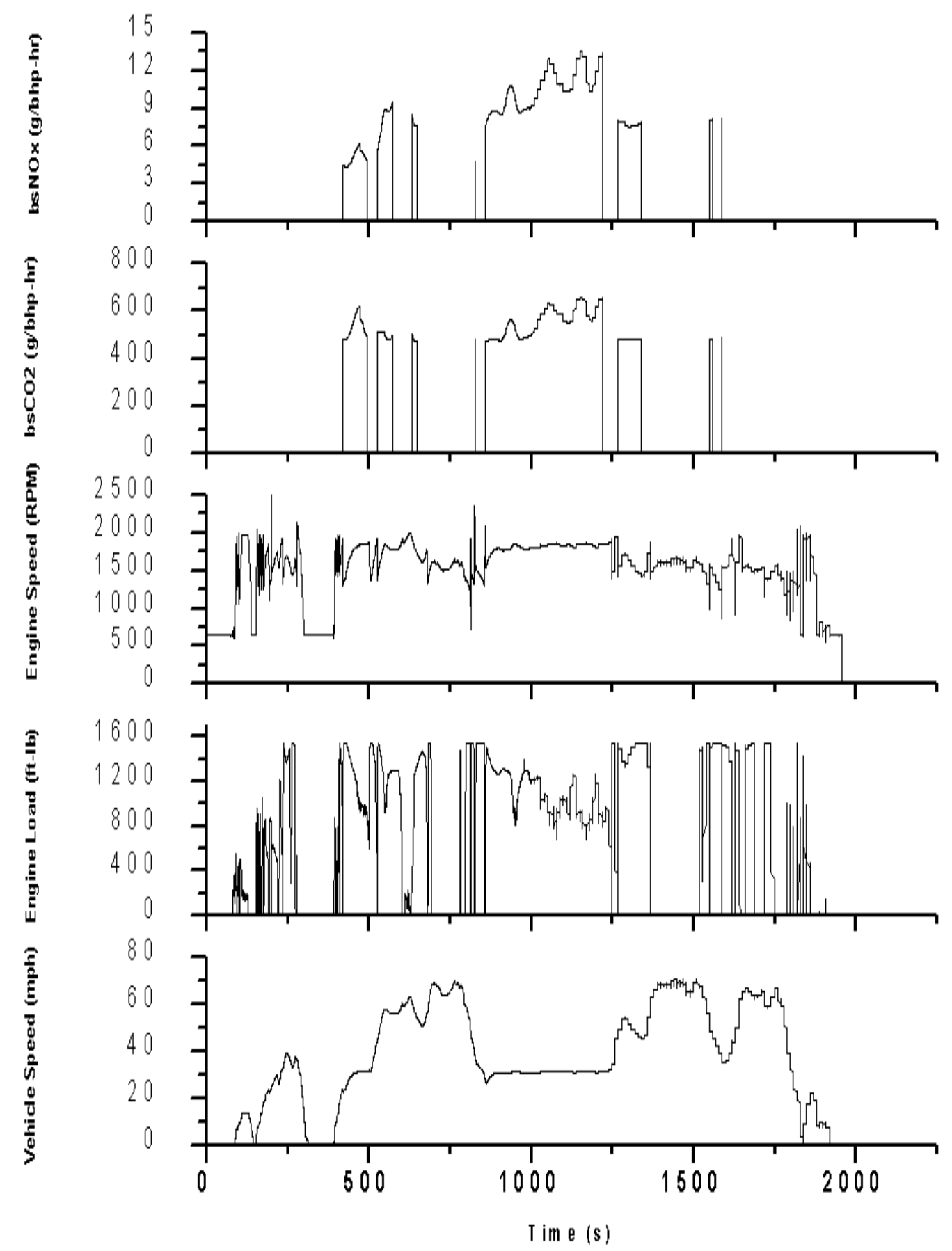

Figure 8.13 Time traces of vehicle speed, engine load, engine speed, bsCO $\mathrm{bl}_{2}$ and $\mathrm{bsNO}_{\mathrm{x}}$ during a SAB2BM route. 

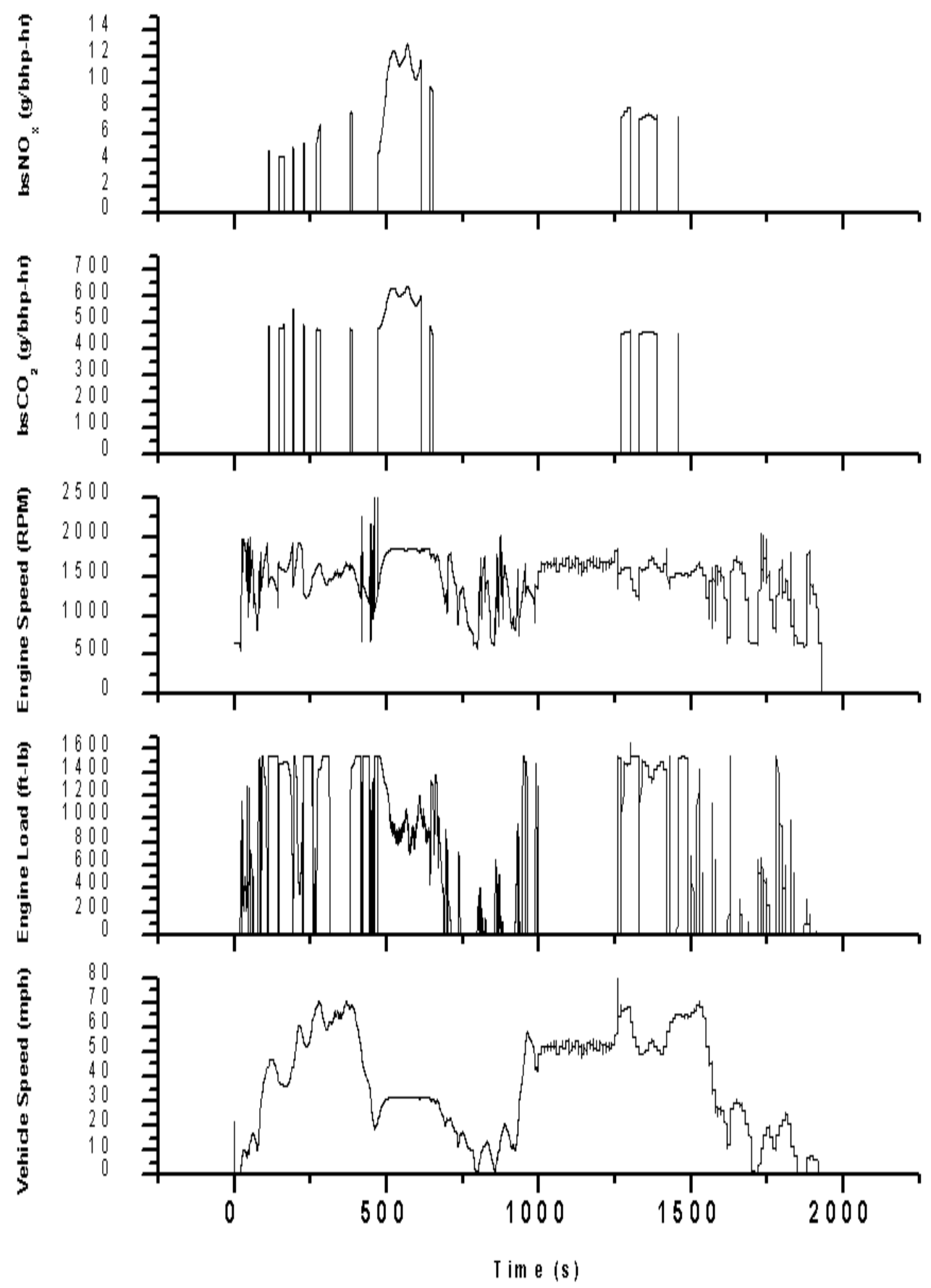

Figure 8.14 Time traces of vehicle speed, engine load, engine speed, $\mathrm{bsCO}_{2}$ and $\mathrm{bsNO}_{\mathrm{x}}$ during a BM2SAB route. 
On the BM2SAB route, most of the NTE operation occurs when the vehicle climbs the hill from Bruceton Mills to the mandatory truck stop at Coopers Rock. After the truck stop, at around 1000 s to 1600 s the road grade is $5 \%$ decent to Cheat Lake and the engine does not operate in the NTE region. Figure 8.14 shows that when the vehicle speed is low (25mph) but the engine is operating at high speed and load that results in higher fueling and higher in-cylinder temperatures, thus causing high $\mathrm{NO}_{\mathrm{x}}$ emissions.

The PA1 leg of the Pittsburgh route was chosen to represent the city-driving pattern. As seen in Figure 8.15, this route does not yield any significant engine operation over 30s continuous windows in the NTE region.

For the PA2 leg it can be observed that peaks characterize the $\mathrm{NO}_{\mathrm{x}}$ emissions during the cruise operation where the vehicle speed was $30 \mathrm{mph}$ but the engine was operating close to full load conditions. During this period the engine was operating in the NTE region with the engine speed constant throughout the period with small fluctuations in engine load. The other 30s NTE zones that was encountered were due to acceleration and deceleration modes. It can be seen from Figure 8.16 that it is the cruise operation that contributes largely to the total $\mathrm{NO}_{\mathrm{x}}$ emissions.

On the PA3 leg, the amount of time the engine spent in the continuous 30 s windows in the NTE region was the highest among the three legs on the Pittsburgh route. Although the vehicle was operating at nearly constant speed throughout the route, NTE windows longer than 42 seconds were not encountered. This can be attributed to the driving behavior and also to slight changes in altitude. Gear shifting could affect continuous NTE windows, and so could a downhill operation, which makes the engine load, fall out of the NTE zone. The average $b_{s N O}$ emitted during this leg was $6 \mathrm{~g} / \mathrm{bhp}-\mathrm{hr}$ and the maximum value was $10 \mathrm{~g} / \mathrm{bhp}-\mathrm{hr}$.

As indicated earlier, the outbound and return journeys of the route were very similar for the Saltwell route, when operating on the I-79 interstate. Brake-specific emissions from these routes were in agreement, with the maximum of $8 \mathrm{~g} / \mathrm{bhp}-\mathrm{hr}$ and an average value of $5 \mathrm{~g} / \mathrm{bhp}-\mathrm{hr}$. A slightly longer 30 s window was observed on the outbound journey. As suggested earlier this difference could be due to driving behavior. 

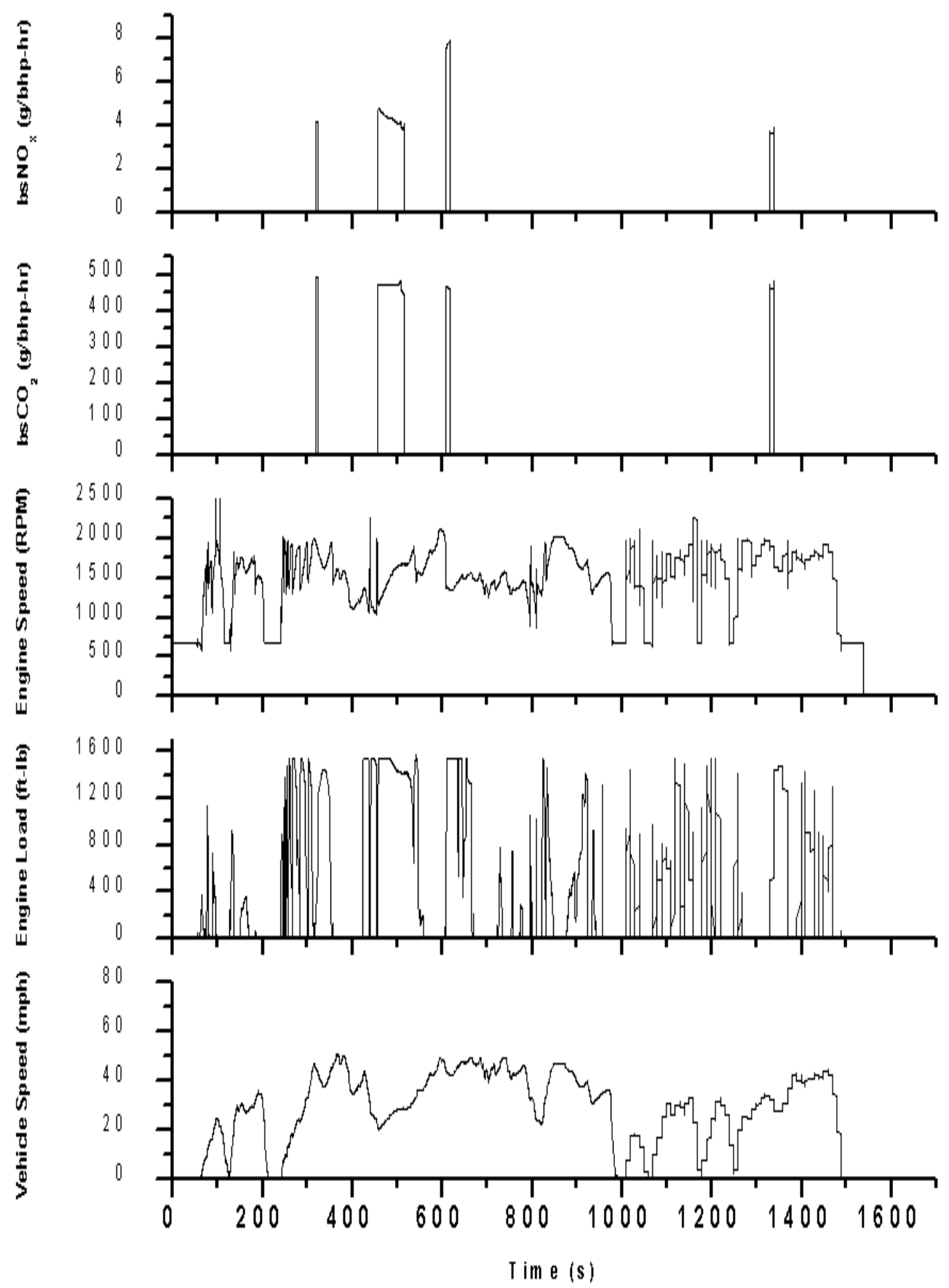

Figure 8.15 Time traces of vehicle speed, engine load, engine speed, bsCO $\mathrm{bl}_{2}$ and $\mathrm{bsNO}_{\mathrm{x}}$ during Leg 1 of Pittsburgh route. 

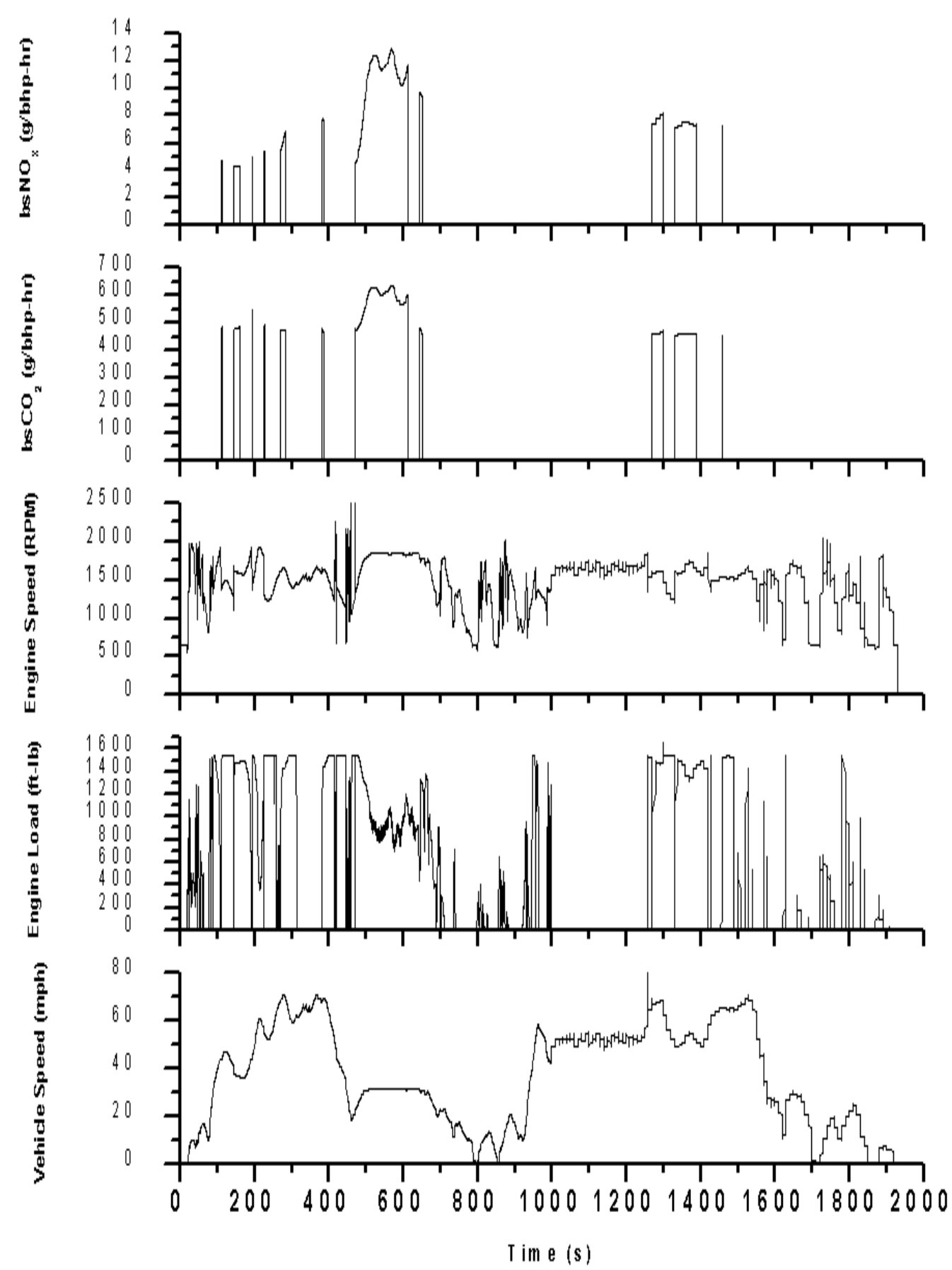

Figure 8.16 Time traces of vehicle speed, engine load, engine speed, bsCO$_{2}$ and bsNO during Leg 2 of Pittsburgh route. 

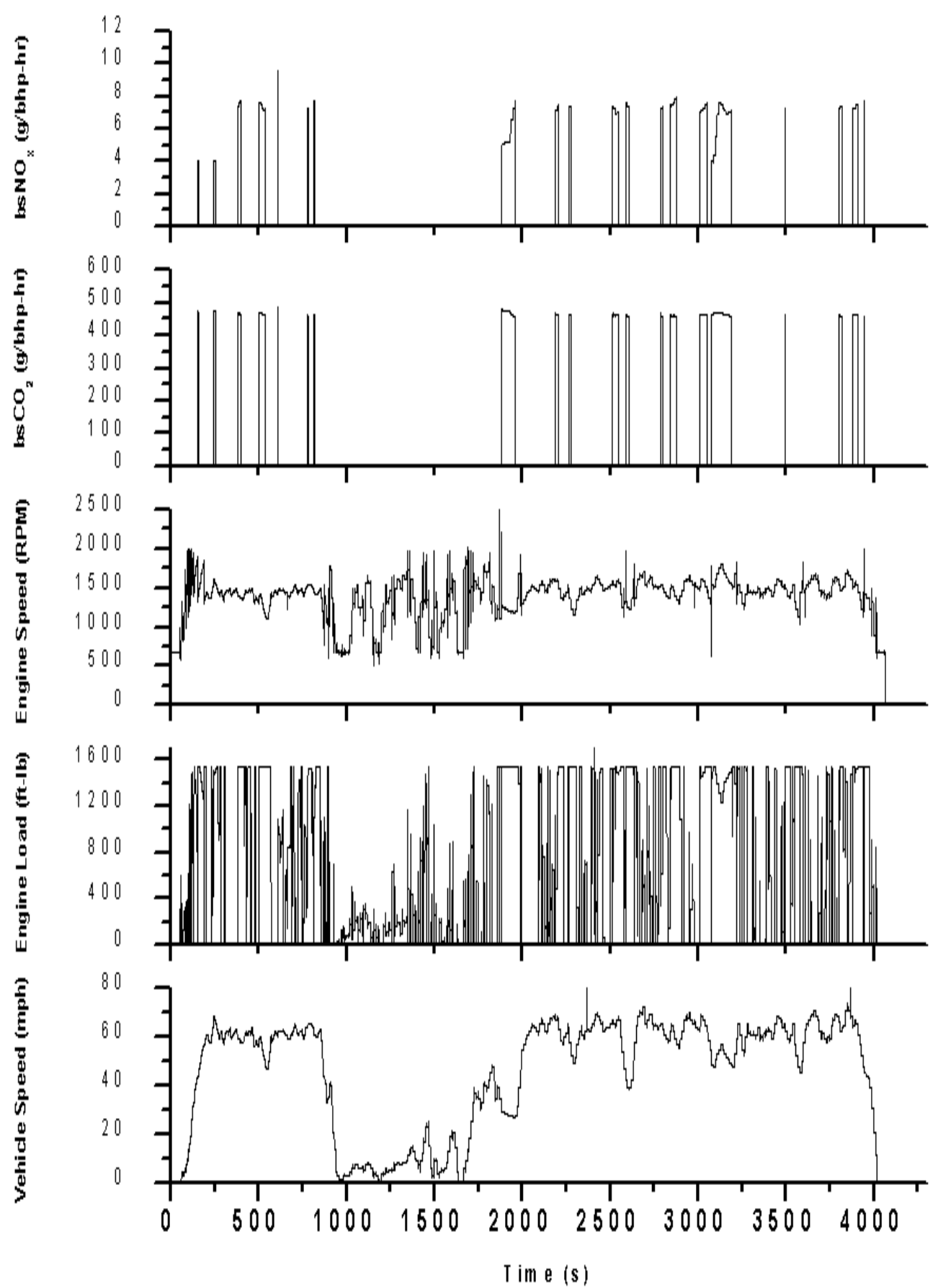

Figure 8.17 Time traces of vehicle speed, engine load, engine speed, bsCO $\mathrm{b}_{2}$ and $\mathrm{bsNO}_{\mathrm{x}}$ during Leg 3 of Pittsburgh route. 

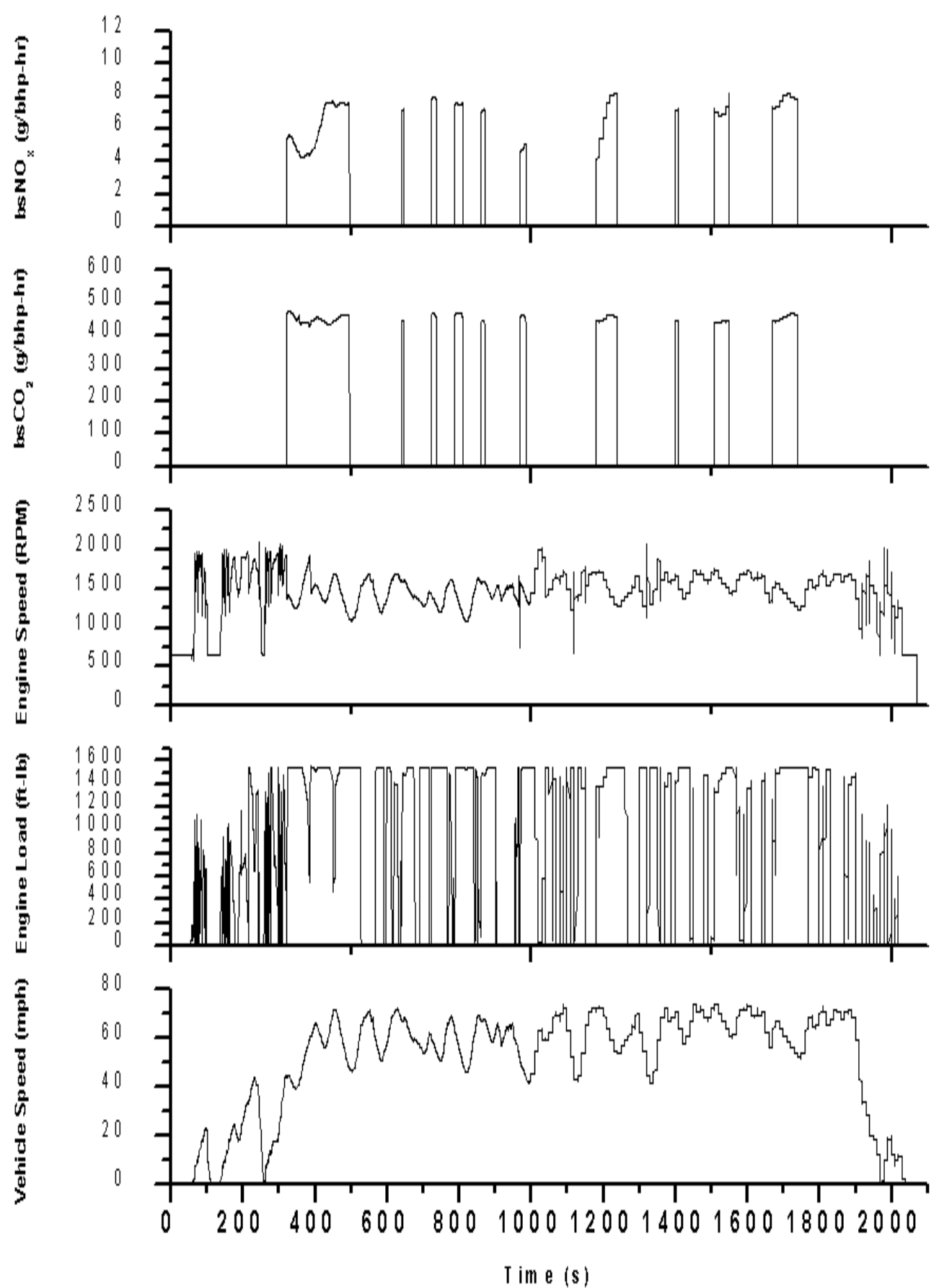

Figure 8.18 Time traces of vehicle speed, engine load, engine speed, bsCO $\mathrm{bl}_{2}$ and $\mathrm{bsNO}_{\mathrm{x}}$ during SAB2SW route. 

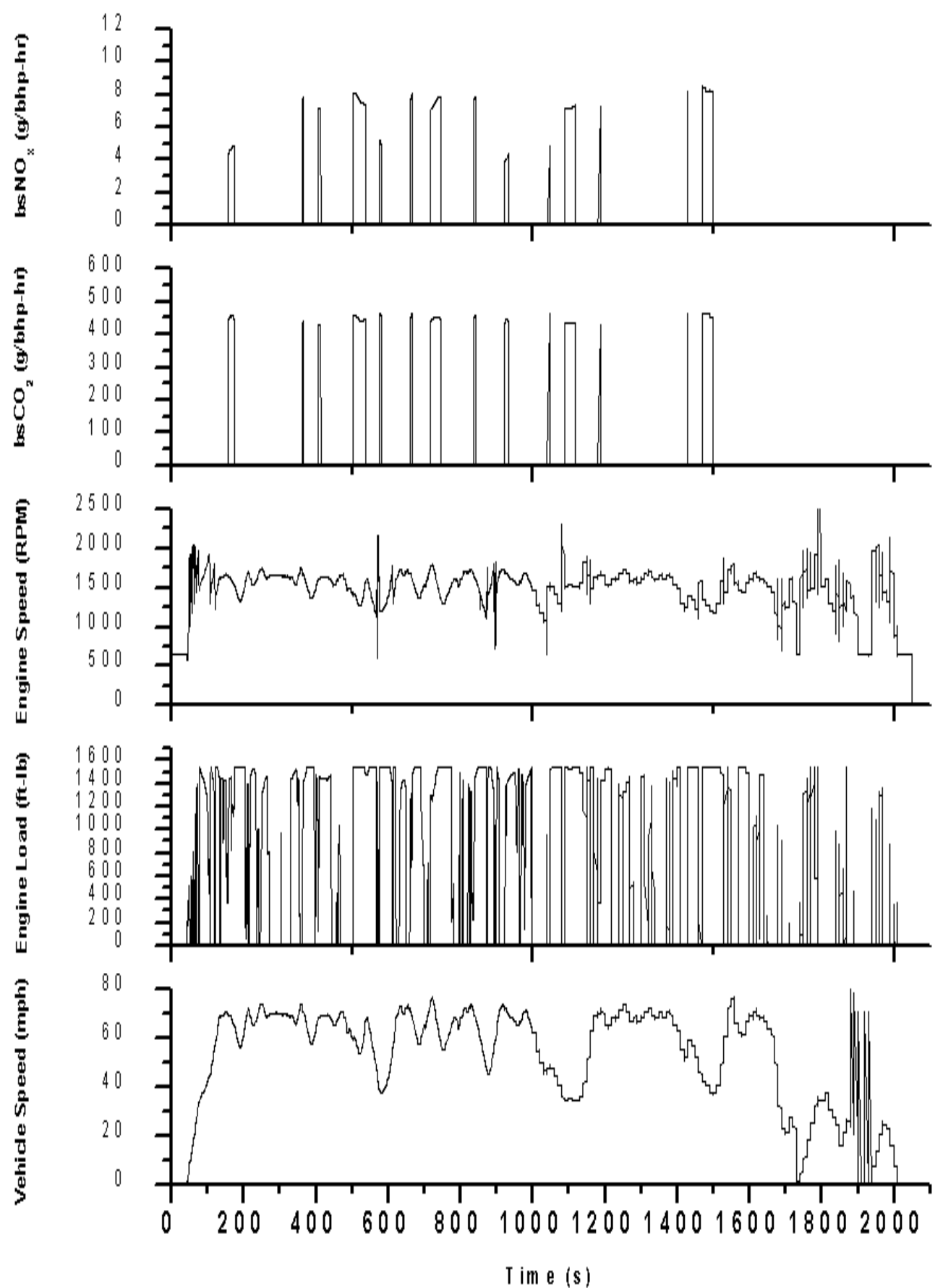

Figure 8.19 Time traces of vehicle speed, engine load, engine speed, bsCO$_{2}$ and bsNO during SW2SAB route. 
The amount of time a vehicle spent in each of the three modes, under consideration, when operating in the NTE zone is shown in Figure 8.20. It can be seen that for all of the test routes, the cruise mode accounts for the majority of the time that the engine operated in the NTE region. The cruise modes occupy about $60 \%$ of the time the vehicle spends in the NTE zone for the SAB2SW and the SW2SAB route. For the Pittsburgh routes the cruise mode constituted about $75 \%$ of the NTE time. Nearly $80 \%$ of the time spent in the NTE region was in cruise mode on the Bruceton Mills route. The acceleration region occupies only about $10-15 \%$ of the time in the NTE region for all the routes. Except for the SAB2SW and SW2SAB route, where the time in the deceleration mode was $30 \%$, all other routes had only $10 \%$ of the total time in the deceleration mode.

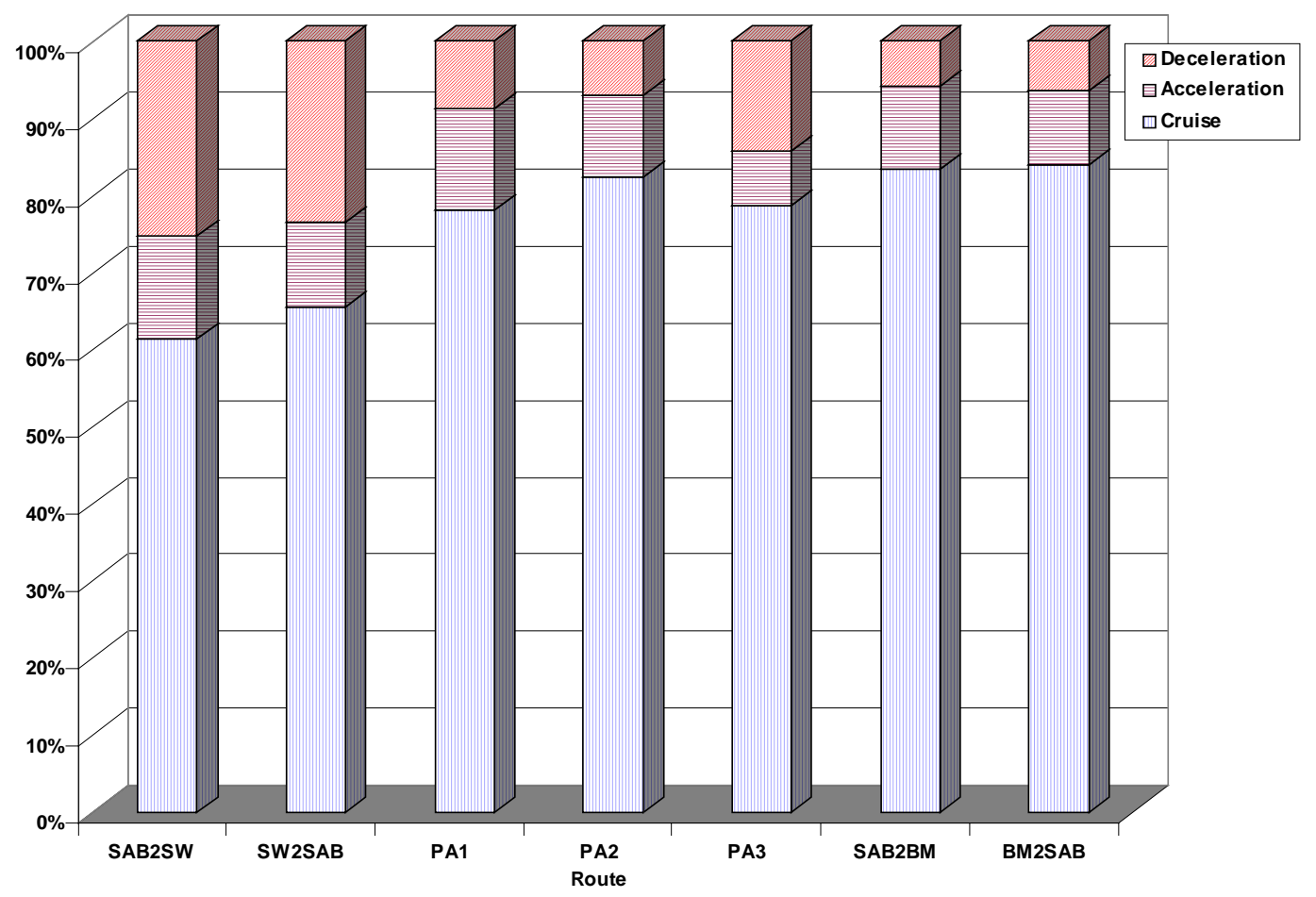

Figure 8.20 Distribution of acceleration, cruise and deceleration modes with respect to time spent in the NTE region on different routes.

A comparison of the average modal emission rate for $\mathrm{NO}_{\mathrm{x}}$ on each of the routes is shown in Figure 8.21. The mean emission rates for $\mathrm{NO}_{\mathrm{x}}$ were the highest for cruise mode. The acceleration mode produces slightly lesser amount of $\mathrm{NO}_{\mathrm{x}}$ emissions compared to the cruise mode and deceleration mode produces the least amount of $\mathrm{NO}_{\mathrm{x}}$ emissions. But it should be noted 
from Figure 8.20 that the acceleration and deceleration modes occupy only very small amount of engine NTE operation time in NTE zone.

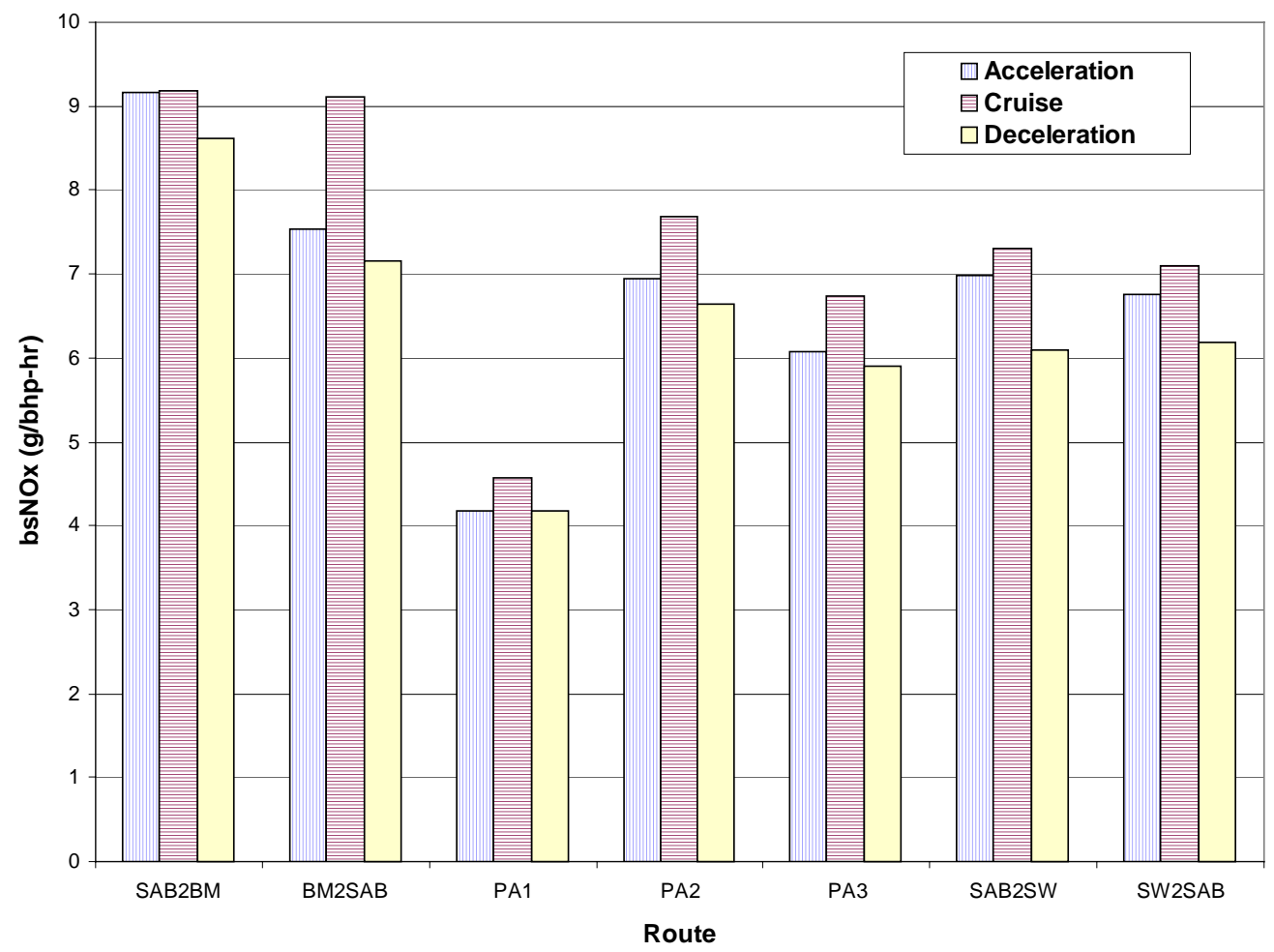

\section{Figure 8.21 Average modal emission rate of $\mathrm{NO}_{\mathrm{x}}$ on different routes for Engine $\mathrm{A}$}

\subsection{Representation of Engine Operation on Lug curve}

The operation of the engine over 30 second windows within the NTE zone can be represented on an speed versus torque plot as shown in Figure 8.22 and Figure 8.23. These figures also show the brake-specific $\mathrm{NO}_{\mathrm{x}}$ emissions as a function of engine speed and engine load. The boundaries of the NTE region are marked in Figure 8.22

Figure 8.22 shows that a majority of the engine operation occurred along the full load curve over the SAB2BM route. It has been found that the torque broadcast at full load conditions compares very well with the actual engine dynamometer load data. 


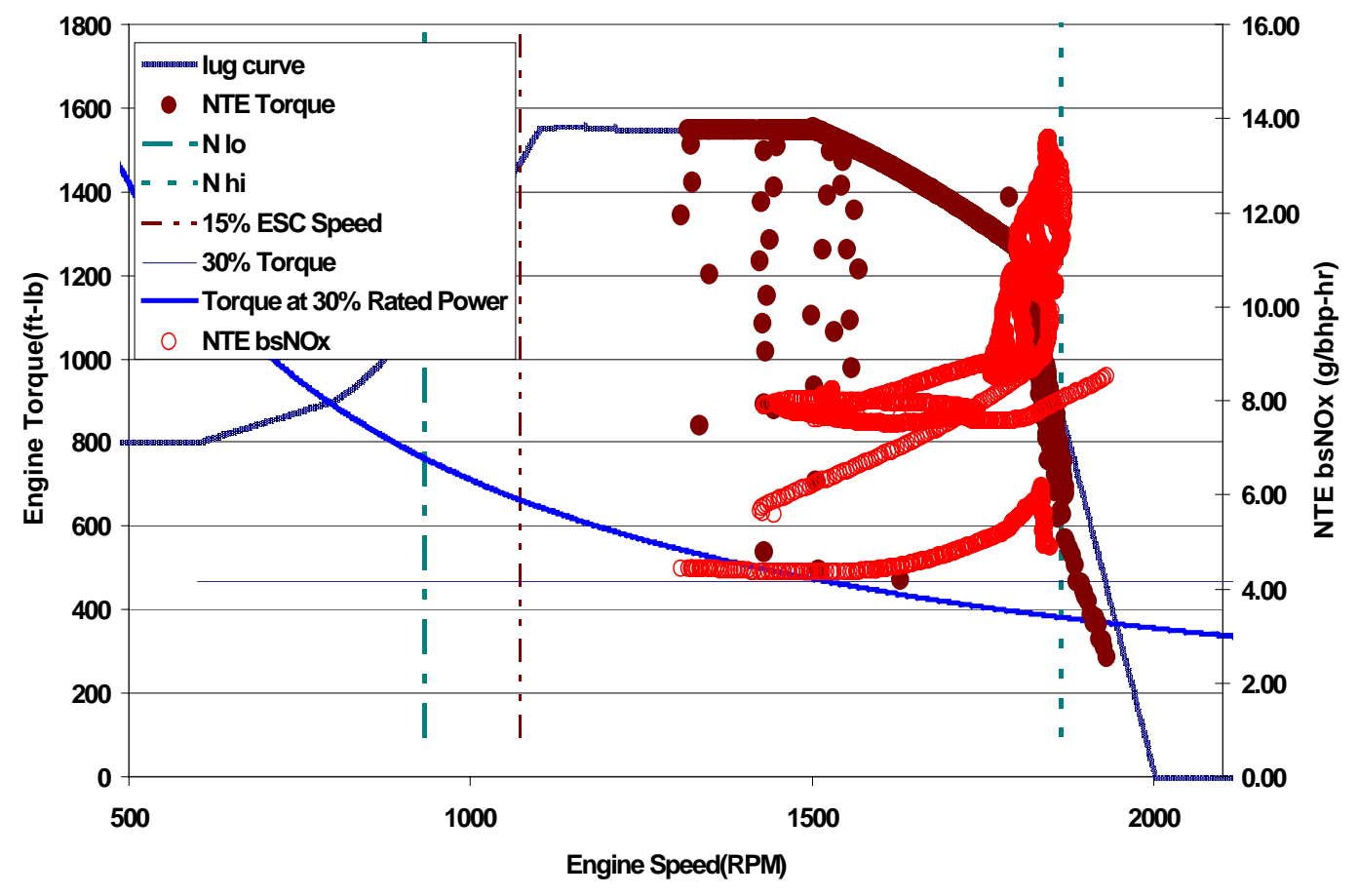

Figure 8.22 Two-dimensional representation of variation of $\mathrm{bsNO}_{\mathrm{x}}$ as function of engine speed and engine torque

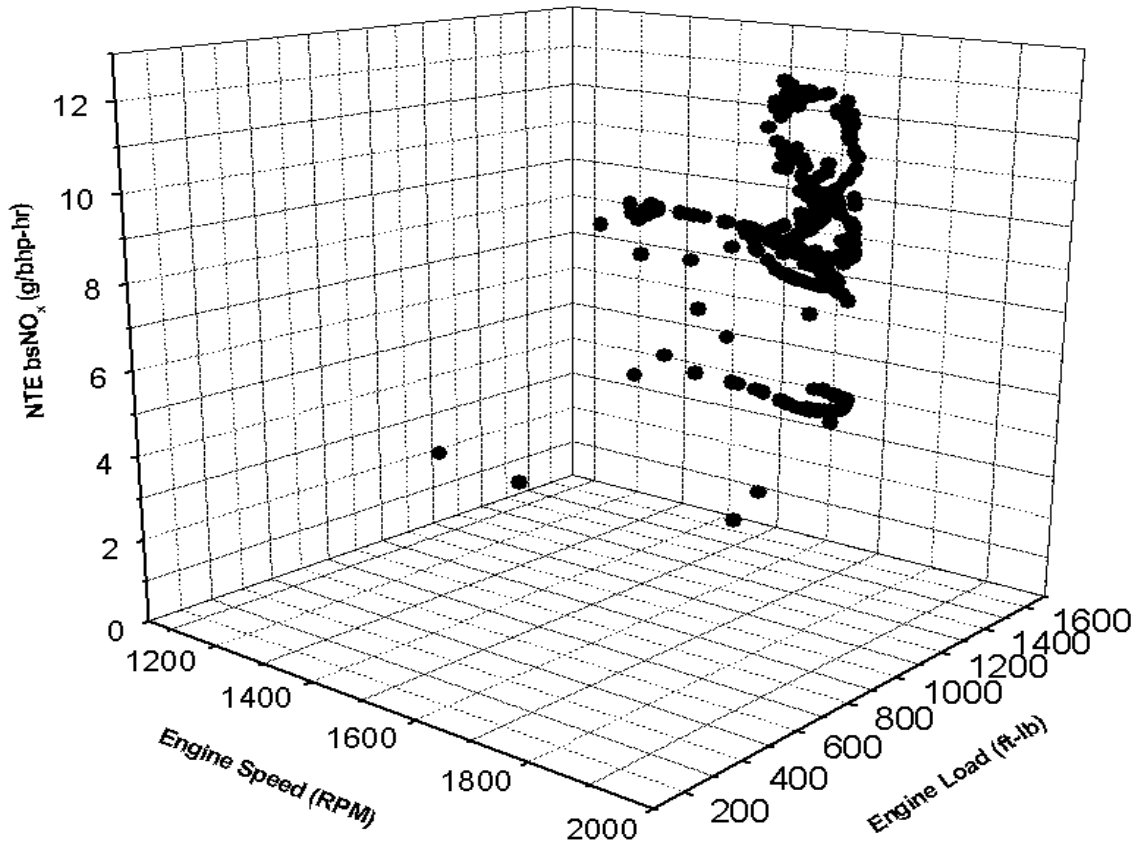

Figure 8.23 Three dimensional representation of variation of $\mathrm{bsNO}_{\mathrm{x}}$ as function of engine speed and engine torque 


\subsection{Comparison of Time Spent in the NTE Region for Different Routes}

Each vehicle was driven on the previously described routes, which were chosen to represent the highway driving and city driving. Hence, the amount of time spent by an engine in the NTE region on each of these routes was different. In calculating the time spent in the NTE region as a function of total time the idle data at the end of the test was limited to 30 seconds to maintain uniformity. To calculate the percentage of time an engine spends in the NTE region, individual NTE points were used in the following equation.

$$
\% \text { Time }_{\text {NTE }}=\frac{\text { Amount_of_Time_in_NTEregion }}{\text { Total_Time_of_Test }} \times 100
$$

Figure 8.24 displays the total time of the test, actual time spent in the NTE region and the time for continuous 30s NTE operation. Figure 8.25 displays the fraction of total time that the engine spent in continuous 30s windows. Figure 8.26 displays the amount of time (as a percentage) that the engine spent in NTE zone when $\mathrm{bsNO}_{\mathrm{x}}$ exceeded the NTE limit. The Figure 8.26 shows percentage of time that was spent in the NTE with $\mathrm{NO}_{\mathrm{x}}$ exceeding the limit, and also as a percentage of total cycle time when the $\mathrm{NO}_{\mathrm{x}}$ exceeded the NTE limit.

Data shows that with the exception of Sabraton to Bruceton Mills Route, the engine spent less than $25 \%$ of the total time as continuous 30 -second windows in the NTE zone. It should be noted that the Sabraton to Bruceton Mills Route was deliberately selected in order to include a significant amount of engine operation in the NTE zone during on-road testing. Despite of that, less than $30 \%$ of the total time was spent in the NTE zone.

It has been observed that only a small fraction of the total driving time leads to levels of brake specific emissions that exceed the NTE limit. Figure 8.26 gives the comparison of the routes for the amount of time that the $\mathrm{bSNO}_{\mathrm{x}}$ exceeds the NTE limit as a percentage of time spent in the NTE region and the total time for the entire route. 


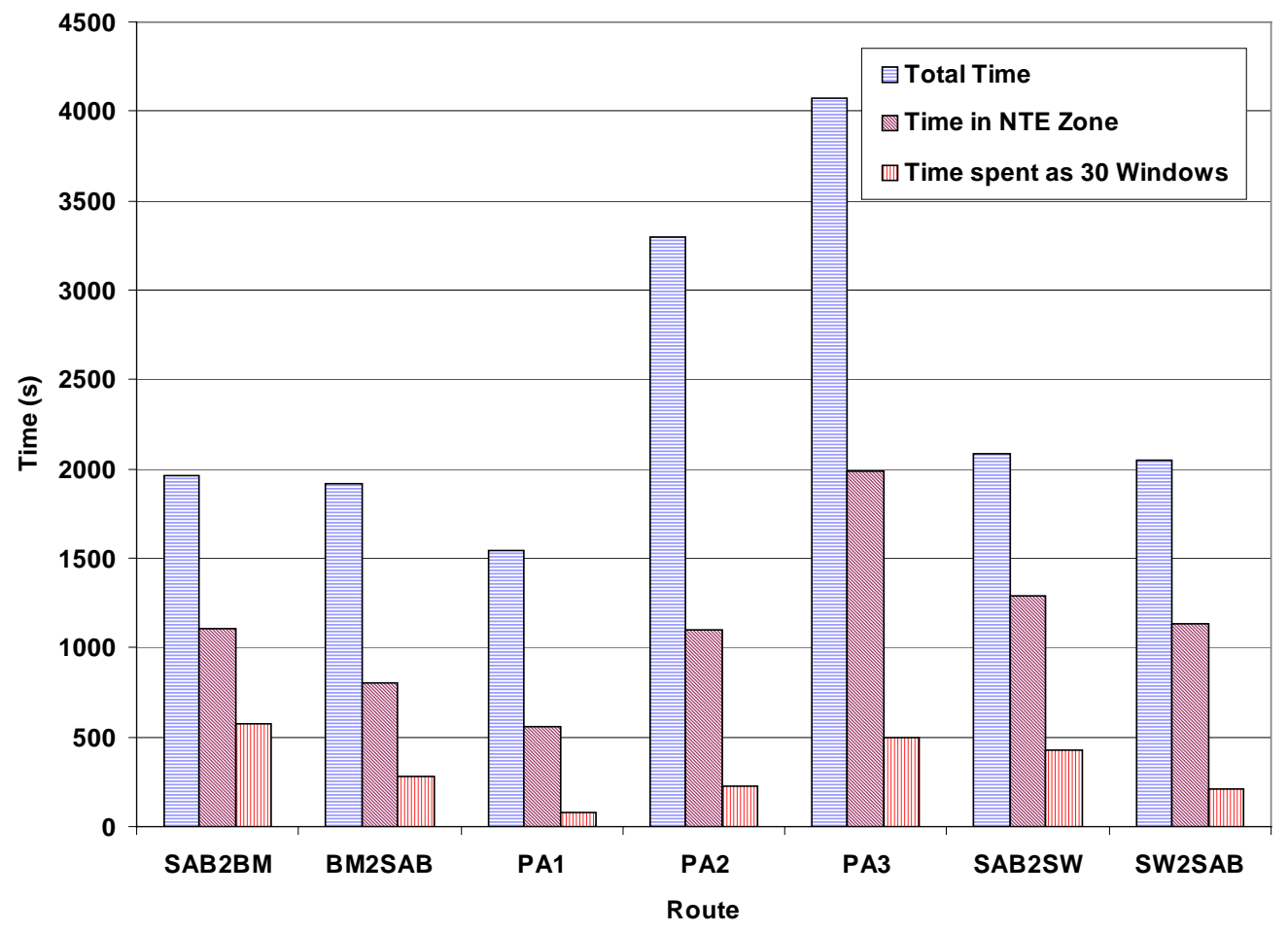

Figure 8.24 Comparison of Time in NTE and 30s windows on different routes

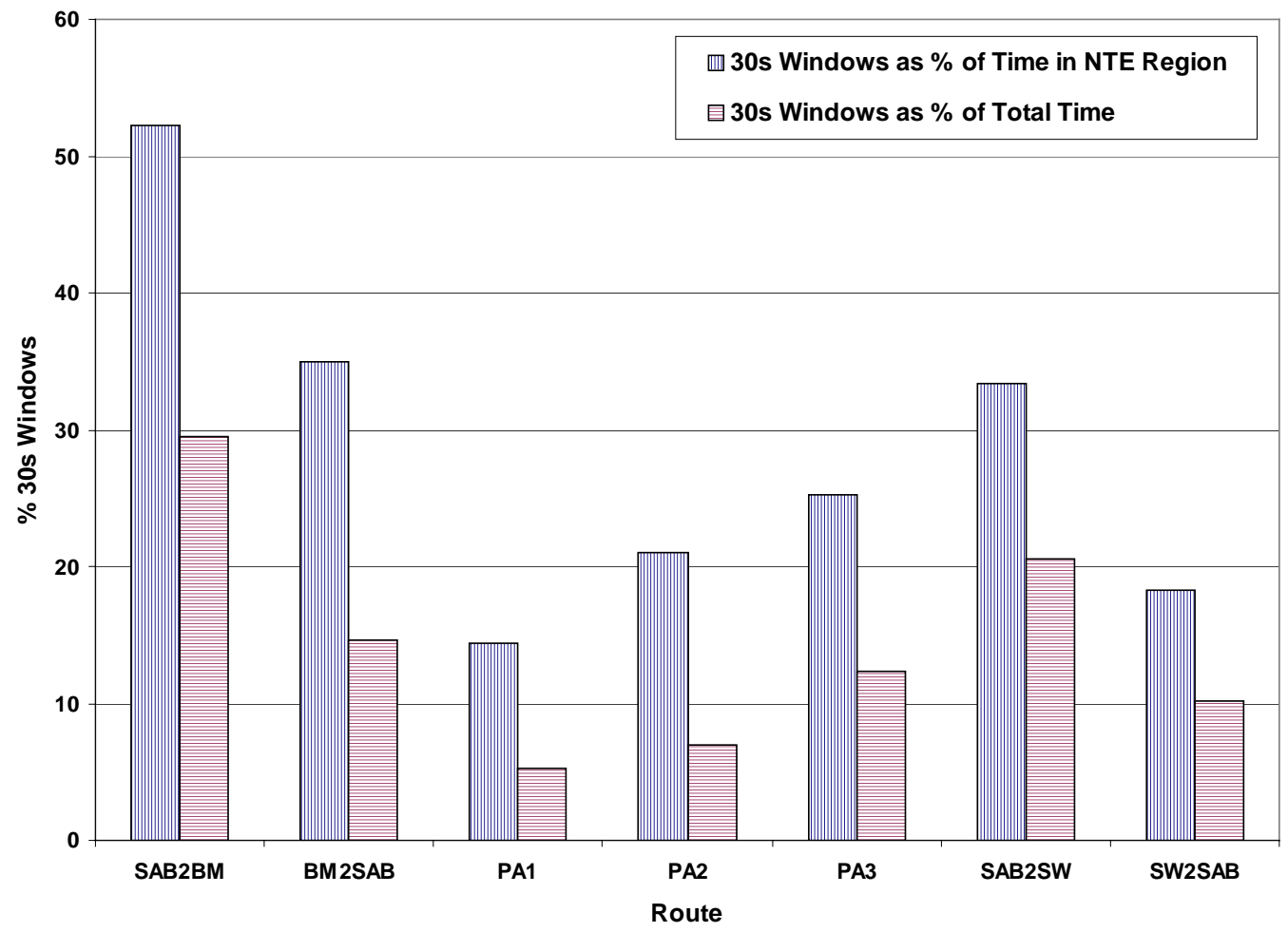

Figure 8.25 Comparison of percentage of 30s windows in NTE region and total time 


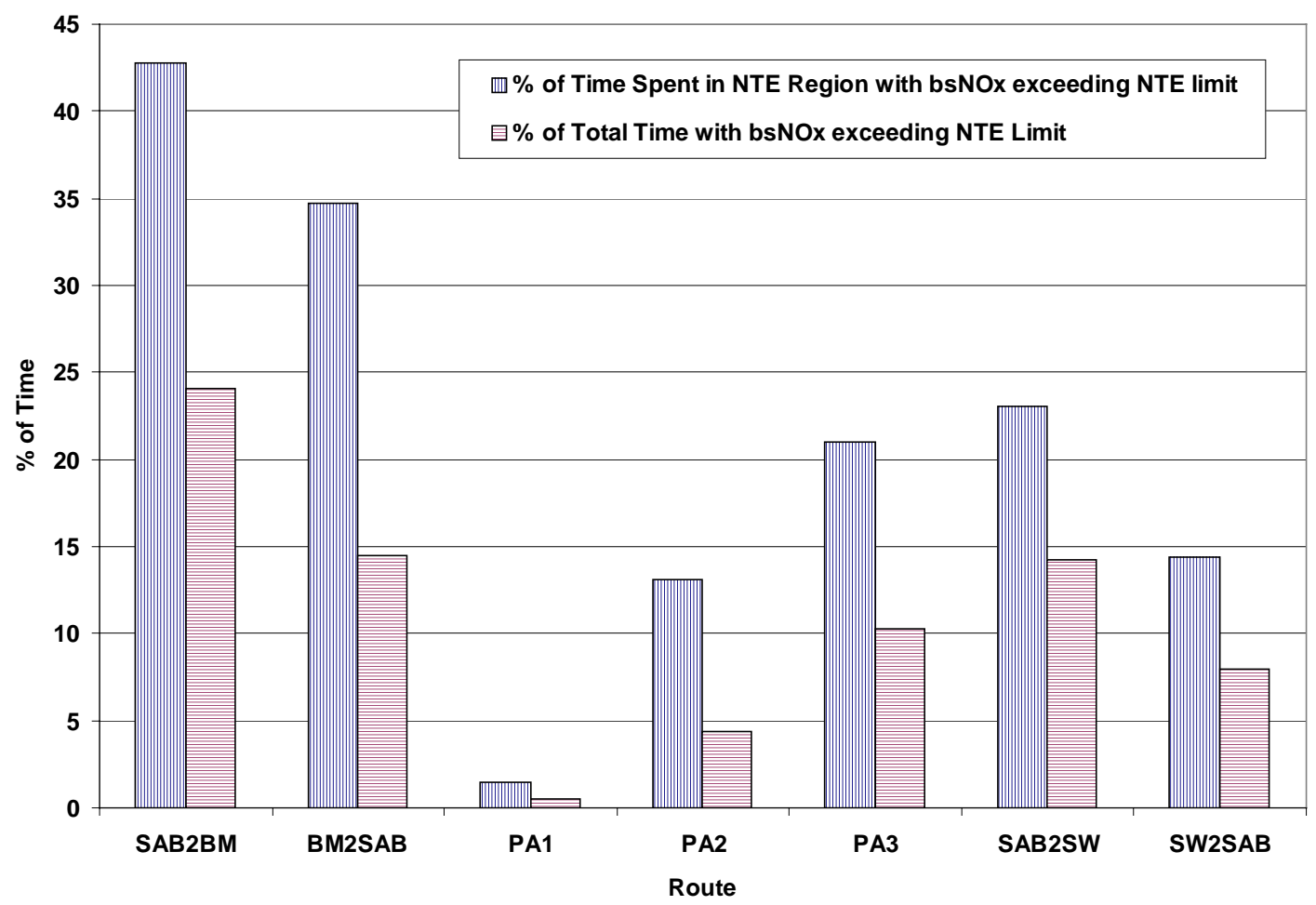

Figure 8.26 Comparison of percentage of 30s windows with bsNO $\mathrm{B}_{\mathrm{x}}$ exceeding NTE limit in NTE zone and total time

\subsection{Engine Parameters Affecting Combustion Process and Emissions}

Emissions from engines are a result of complex combustion processes that occur inside the engine cylinders. Various factors affect the combustion process including the operating parameters such as engine speed and load. The combustion process in a diesel engine can be divided into four periods, namely the ignition delay, premixed combustion, diffusion combustion and combustion tail [57]58].

Ignition delay is defined as the period between the injection of fuel into the cylinder and the time ignition starts. The ignition delay can be divided into two processes namely physical delay and chemical delay. The physical delay accounts for the time required to atomize the fuel, heating the fuel by the surrounding air, and the mixing of fuel with air to form an ignitable mixture. The chemical delay accounts for the breaking up of fuel molecules to form fragments, reacting with oxygen in air and increasing the chemical reaction rate exponentially. The combustion process that occurs before the complete mixing of fuel is characterized as premixed combustion. The diffusion combustion is characterized by the mixing between the air and the fuel spray. Since the reaction occurs at a very rapid rate, there is very little time for flame propagation and increase in peak flame temperature. 
Of the four stages, ignition delay is of prime importance since it contributes largely to $\mathrm{NO}_{\mathrm{x}}$ formation inside the cylinder. The engine operating parameters such as engine speed and load significantly affect the ignition delay period. Following sections discusses how these parameters affect the NTE emissions.

\subsubsection{Effect of Engine Load on Brake-Specific Emissions}

Engine load plays a very important role in affecting the emissions from engines. Figure 8.27 displays the variation of $b_{s} \mathrm{NO}_{\mathrm{x}}$ as a function of engine load. As engine load increases there is an increase in the amount of fuel injected for the same mass of air at constant speed. With more fuel being burnt there is an increase in the in-cylinder adiabatic flame temperature. High combustion temperatures provide the needed energy for the chemical reactions that lead to $\mathrm{NO}_{\mathrm{x}}$ formation. The higher bsNO ${ }_{x}$ emissions were observed on the SAB2BM route where the vehicle was driving uphill at a constant speed of $25 \mathrm{mph}$, the load was increasing and the engine was operating at about $1800 \mathrm{rpm}$. The higher load during the SAB2BM route also explains the higher brake-specific fuel consumption for this route compared to other routes. Similarly, there are instances where bsNO $\mathrm{x}_{\mathrm{x}}$ emissions increase while there is a decrease in the $\mathrm{bsCO}_{2}$ emissions. This indicates an increase in the fuel efficiency. This is possible when the thermal efficiency of the combustion process increases and produces the same amount of work output with lesser fuel consumption. This can be attributed to the change in injection timing, where the injection timing is advanced to increase the ignition delay and aid in premixed combustion. Premixed combustion helps in increasing the peak flame temperature and hence, the thermal efficiency. The higher temperatures are particularly important in the formation of NO. Such modifications to timing strategy that were used by the manufacturers did result in an increase in the fuel economy but also increased the bsNO ${ }_{x}$ emissions. Such strategies were labeled as "defeat devices" in the Consent Decrees 9 .

It can be inferred from Figure 8.28 that the highest $\mathrm{bsNO}_{\mathrm{x}}$ emissions need not occur at full load conditions. For example, on a SW2SAB route, the maximum bsNO $\mathrm{N}_{\mathrm{x}}$ emissions were observed at $80 \%$ full load conditions. Similar pattern was observed on a PA2 route. The Bruceton route appeared to be an exception, since the majority of NTE operation on this route occurred only at full load conditions. It can be observed that there was a very slight variation in the average load conditions when the bsNO $\mathrm{x}_{\mathrm{x}}$ emissions conformed to and when they exceeded the NTE limits. 


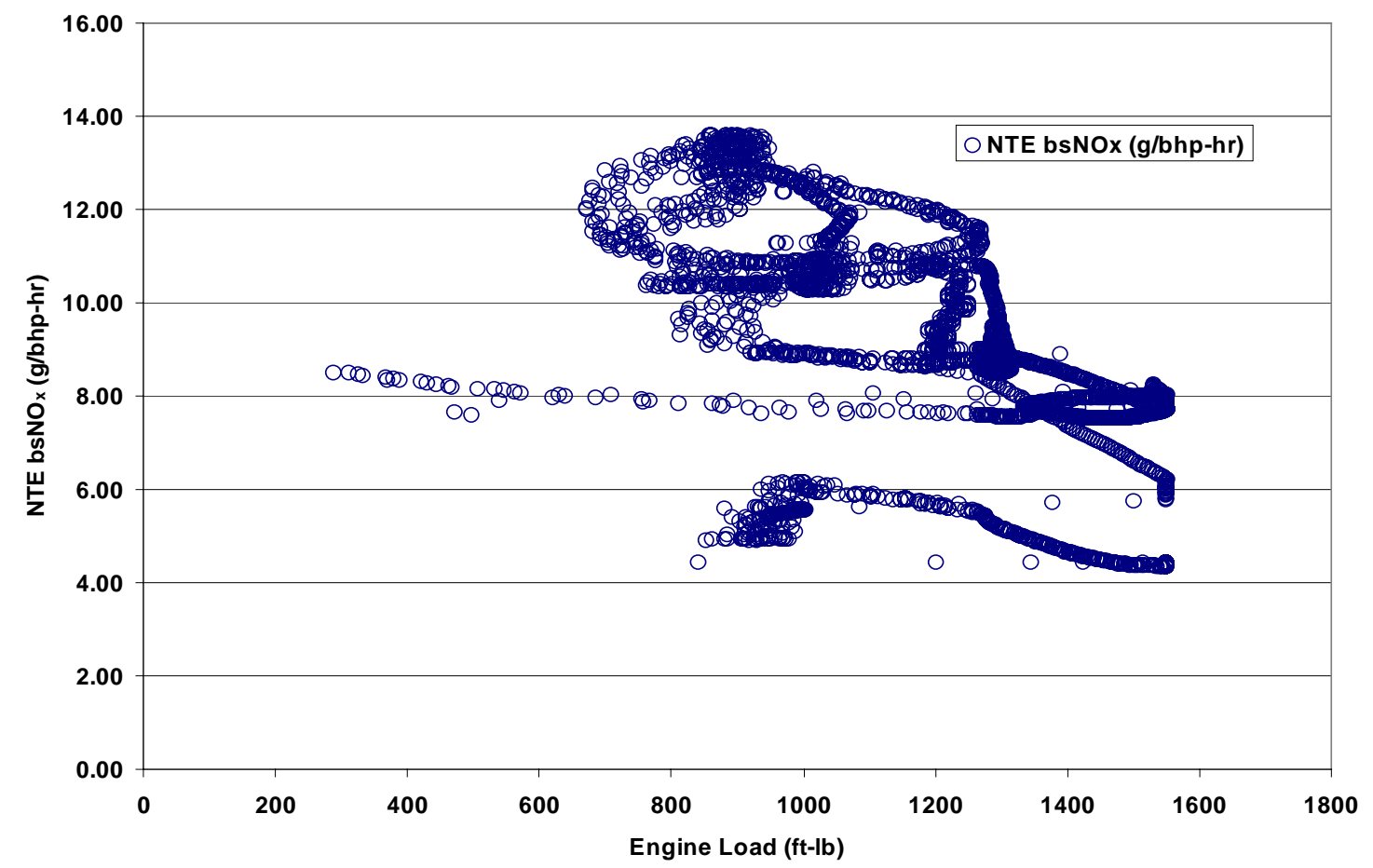

Figure 8.27 Variation of $b^{2} \mathrm{NO}_{\mathrm{x}}$ with engine load

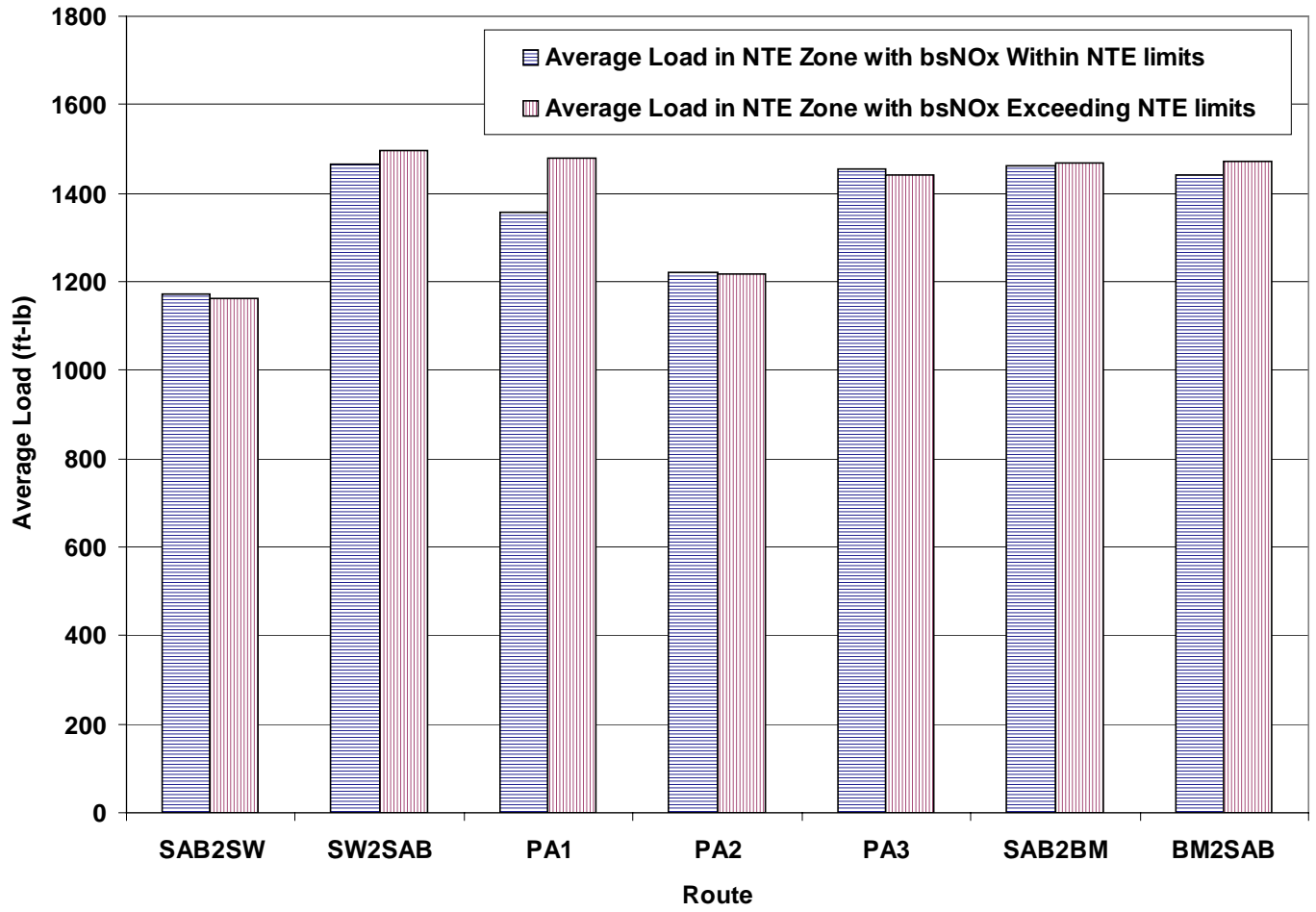

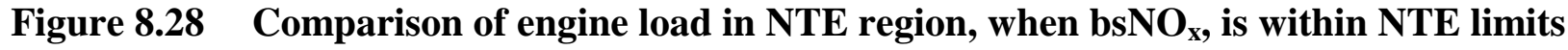
and exceeds NTE limits 


\subsubsection{Effect of Engine Speed on Brake-Specific Emissions}

Engine speed in addition to load is one of the major factors that affect emissions from diesel engines. Heavy-duty diesel engines are designed to produce best fuel economy when operating at lower engine speeds and higher engine speeds for better performance. Higher engine speeds increase the ignition delay as measured in degrees of crank angle. Also, at higher engine speeds there is improved air and fuel mixing due to enhanced turbulence, while not affecting the chemical delay. Thereby, decreasing the time available for $\mathrm{NO}_{\mathrm{x}}$ formation. In this study, the variation of brake-specific $\mathrm{NO}_{\mathrm{x}}$ as a function of engine speed during operation in the NTE region is analyzed. Figure 8.29 displays the variation of $\mathrm{bsNO}_{\mathrm{x}}$ as a function of engine speed. It can be observed that the engine speeds within the NTE region were in the range of $60-100 \%$ of the rated speed. It should also be noted that engine spent the largest time at the rated speed. This is illustrated in by Figure 8.30 where it can be seen that the average engine speed within the NTE region on different routes was $90-100 \%$ of rated speed. With $b_{s N O}$ emissions exceeding the NTE limits, it was observed that the engine was operating at higher speeds. The increase in $\mathrm{bsNO}_{\mathrm{x}}$ emissions can be attributed to the changes in load conditions where load increases up to the full load conditions, which in-turn affects the fueling conditions.

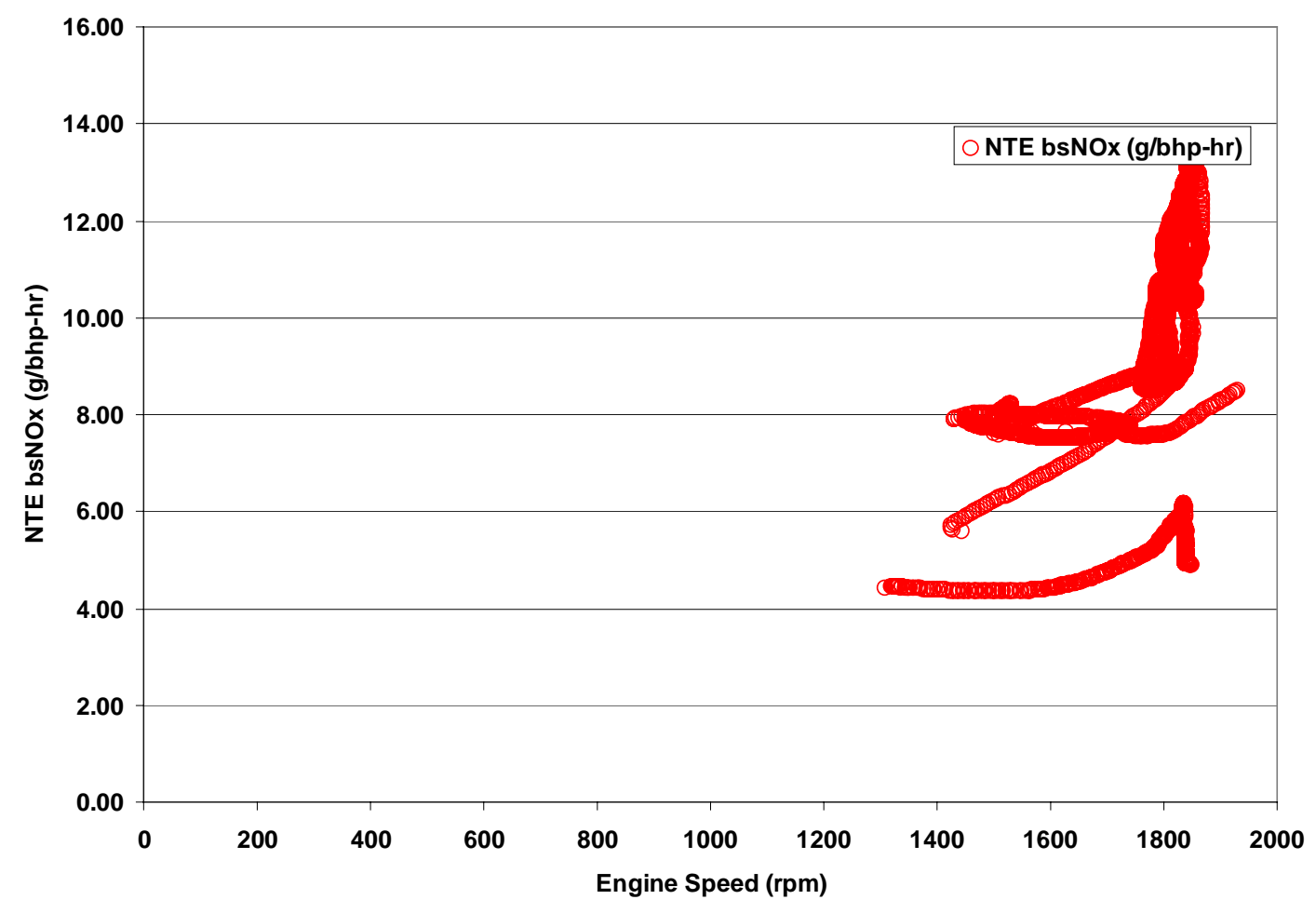

Figure 8.29 Variation of $b^{2} \mathrm{NO}_{x}$ with engine speed 


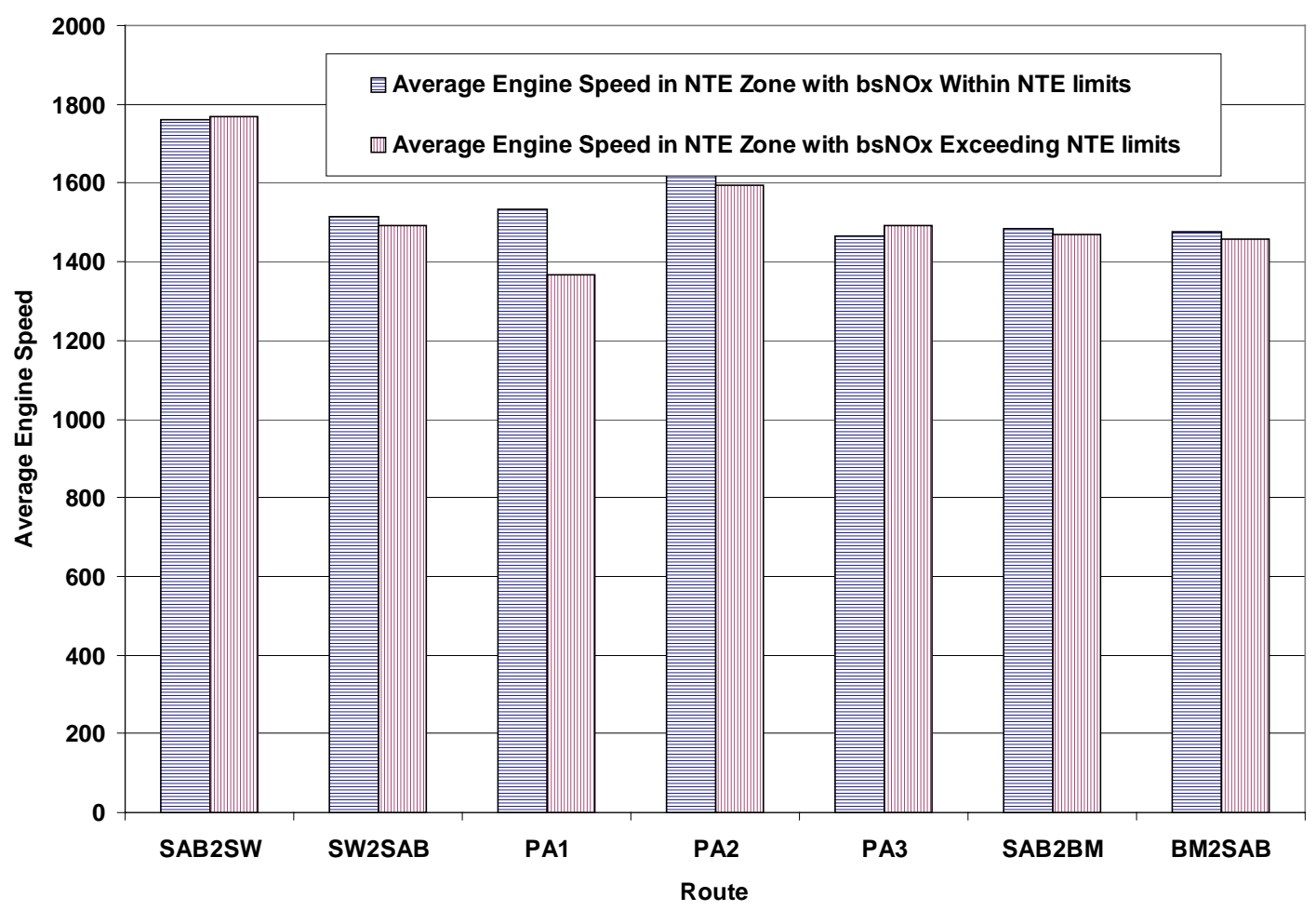

Figure 8.30 Comparison of engine speed in NTE region, when $b_{s N O_{x}}$, is within NTE limits and exceeds NTE limits

\subsubsection{Effect of Engine Power on Brake-Specific Emissions}

The engine power is a function of both engine speed and engine load. Data from the various on-road tests suggest that when the engine operates at full load conditions, the engine speed is less than rated speed, whereas when the engine load drops below maximum the engine operates close to rated conditions. At high speed and low load operations the effect on emissions would be a decrease in $\mathrm{bsNO}_{\mathrm{x}}$ due to factors discussed in previous section. Similarly at high load and lower speed conditions the combustion characteristics are affected, as explained earlier in Section 8.5 .1 and there was increase in bsNO ${ }_{x}$ emissions.

As part of the characterization study the variation of $b_{s N O}$ as a function of engine power alone was analyzed. It can be seen that the engine power during NTE operation was close to $100 \%$ of maximum power for a majority of time. From the previous discussion of engine speed and engine load, at low load conditions, the engine speed was close to rated speed. This can be clearly seen on a PA2 route, where the average load during NTE operation is not at maximum but the engine speed is close to rated speed. This explains the obvious dependence on both engine load and speed conditions, but when engine power alone is considered, it is noted that emissions are the highest at approximately $90-100 \%$ of full power. 


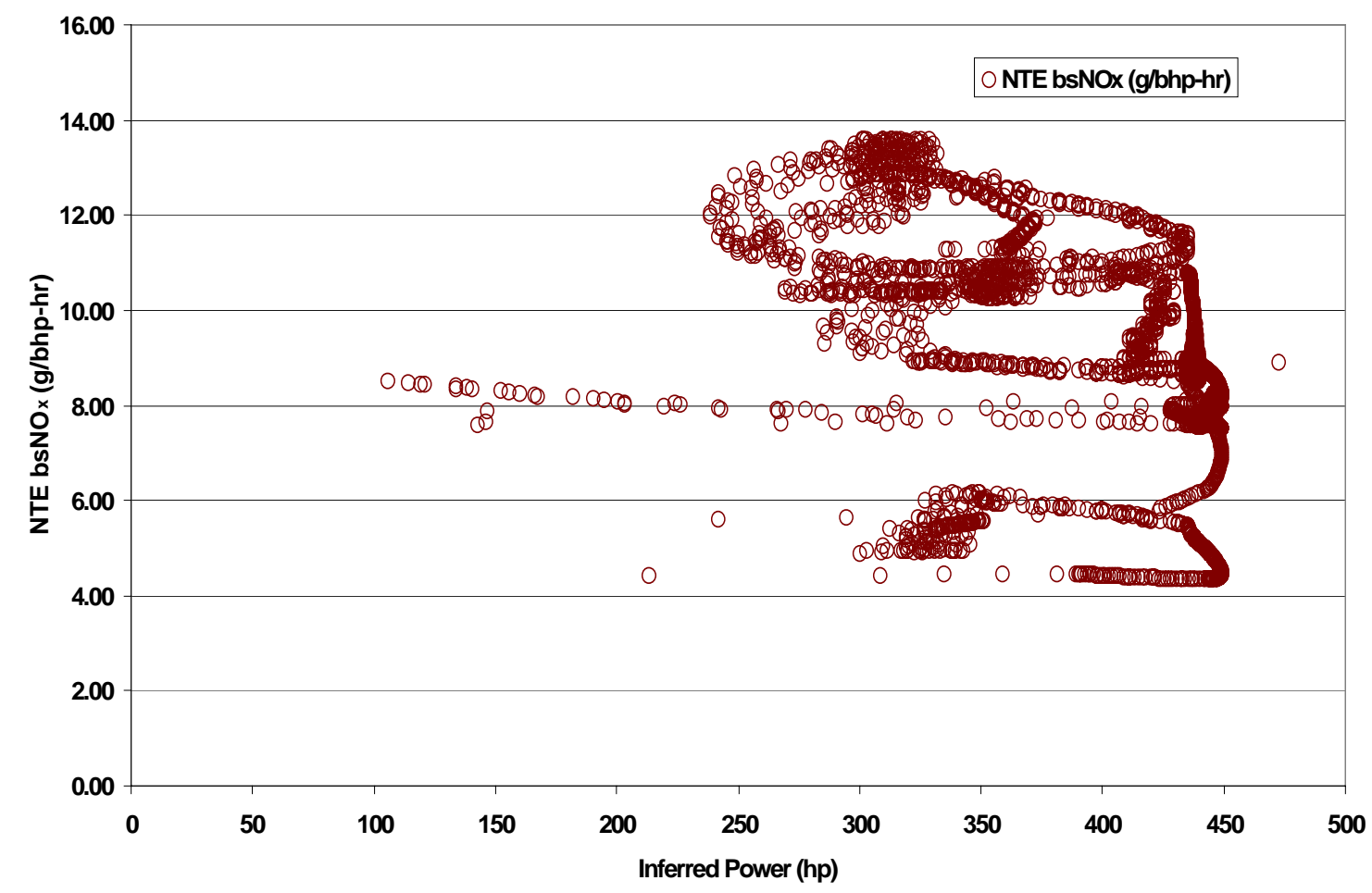

Figure 8.31 Variation of $\mathrm{bsNO}_{\mathrm{x}}$ with engine power

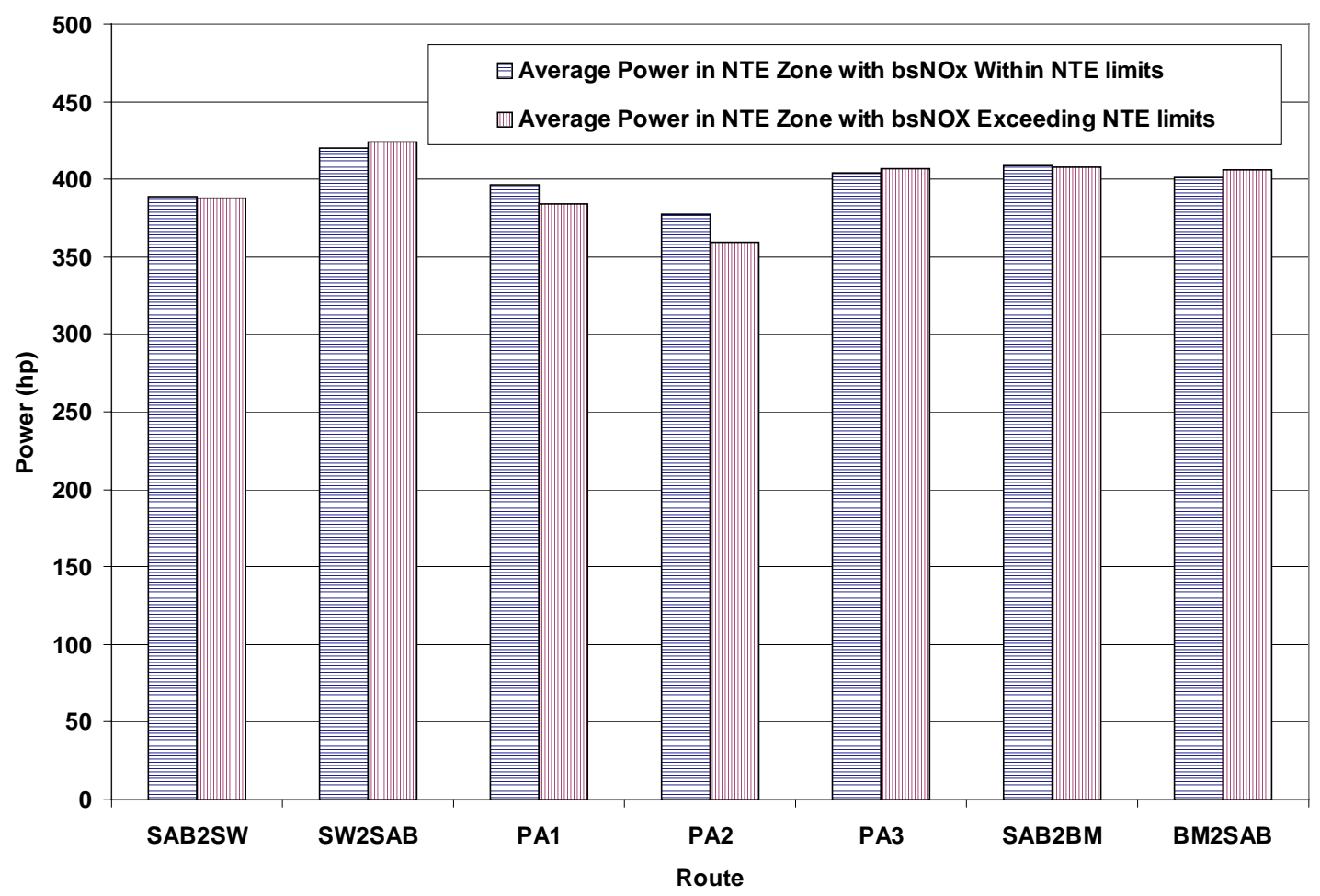

Figure 8.32 Comparison of engine power in NTE region when $b_{s N O}$, is within NTE limits and exceeds NTE limits 


\subsection{Quantification of NTE Emissions based on $\mathrm{NO}_{\mathrm{x}} / \mathrm{CO}_{2}$ Ratios}

The uncertainty analysis performed on the MEMS system clearly indicates that the major factor contributing to the total uncertainty is the uncertainty in the flow measurement. Results show that the uncertainty due to flow reaches up to $5 \%$ for exhaust flow when engine operates within the NTE region. Attempt has been made to find an alternative to reduce or eliminate the error contributed by flow measurement. Analysis has been done to calculate the ratio of $\mathrm{NO}_{\mathrm{x}}$ and $\mathrm{CO}_{2}$ and create a baseline to quantify the NTE emissions based on the ratios. It had been found that the uncertainty in emissions decreases significantly when emissions are expressed as a ratio of $\mathrm{NO}_{\mathrm{x}}$ and $\mathrm{CO}_{2}$.

The global objective of this set of analysis is to establish a factor for the $\mathrm{NO}_{\mathrm{x}} / \mathrm{CO}_{2}$ ratio that can be used to quantify the NTE emissions. The assumptions and approximations that were adopted in the process are discussed below.

The first step in this analysis was to approximate the FTP values of $\mathrm{CO}_{2}$. The average value of brake-specific $\mathrm{CO}_{2}$ obtained from the laboratory testing or as published by the manufacturer was used in calculations. Also, the allowable value of brake-specific $\mathrm{NO}_{\mathrm{x}}$ corresponding to each engine model year was used. For example for an engine MY 1998, a brake-specific $\mathrm{NO}_{\mathrm{x}}$ value of $4.0 \mathrm{~g} / \mathrm{bhp}$-hr was used whereas for a 1996 engine $5.0 \mathrm{~g} / \mathrm{bhp}$-hr was used. The brake-specific $\mathrm{CO}_{2}$ values used were obtained from the emissions results of FTP cycles that the engine was exercised on the engine dynamometer. The ratio of these two values is referred to as the FTP $\mathrm{NO}_{\mathrm{x}} / \mathrm{CO}_{2}$ ratio or the FTP ratio.

The fuel specific $\mathrm{NO}_{\mathrm{x}}$ was calculated as a ratio $\mathrm{NO}_{\mathrm{x}}$ and $\mathrm{CO}_{2}$ values obtained from the on-road tests for the NTE zone. This ratio was then expressed as a function of the FTP fuel specific $\mathrm{NO}_{\mathrm{x}}$.

To illustrate the determination of the ratio of on-road fuel specific $\mathrm{NO}_{\mathrm{x}}$ and FTP fuel specific $\mathrm{NO}_{\mathrm{x}}$, a MY 1997 engine was considered. The allowable brake-specific $\mathrm{NO}_{\mathrm{x}}$ value for an FTP test is $5.0 \mathrm{~g} / \mathrm{bhp}$-hr. From laboratory testing the average value of brake-specific $\mathrm{CO}_{2}$ obtained for an FTP test was $525 \mathrm{~g} / \mathrm{bhp}$-hr. Thus, the FTP fuel specific $\mathrm{NO}_{\mathrm{x}}$ was calculated to be 0.0095 .

As a next step the average value of the fuel specific $\mathrm{NO}_{\mathrm{x}}$ was calculated for one of the routes on which the vehicle was tested, and it was found to be 0.0139 . This ratio was then 
expressed as a function of the FTP fuel specific $\mathrm{NO}_{\mathrm{x}}$ by dividing the on-road ratio with the FTP ratio.

On-road bsNO ${ }_{\mathrm{x}}$ value $\quad=5.85 \mathrm{~g} / \mathrm{bhp}-\mathrm{hr}$

On-road bsCO $\mathrm{bl}_{2}$ value $\quad=487.5 \mathrm{~g} / \mathrm{bhp}-\mathrm{hr}$

On-road ratio/FTP ratio $\quad=1.26$

NTE allowed limit for bsNO $\mathrm{x}_{\mathrm{x}}=6.25 \mathrm{~g} / \mathrm{bhp}-\mathrm{hr}$

The calculation of the ratio factor for this MY 1998 engine on different routes is shown in Table 8-2 Similarly the ratio factor was found for different model year engines operating on different routes. Additional values of ratio factor for different engines on different routes are given in APPENDIX B.

Table 8-2 Baseline $\mathrm{NO}_{\mathrm{x}} / \mathrm{CO}_{2}$ calculations for a $\mathrm{MY} 1997$ engine

\begin{tabular}{|c|c|c|c|c|c|c|}
\hline \multicolumn{7}{|c|}{ Engine Model Year 1997} \\
\hline \multicolumn{2}{|c|}{ Allowed FTP bsNOx } & 5.0000 & & & & \\
\hline \multicolumn{2}{|c|}{ Allowed FTP bsCO2 } & 525.00 & & & & \\
\hline \multicolumn{2}{|c|}{ FTP Ratio } & 0.00950 & & & & \\
\hline \multicolumn{2}{|c|}{ Allowed NTE bsNOx } & 6.2500 & & & & \\
\hline \multirow[t]{2}{*}{ Route/Leg } & \multicolumn{2}{|c|}{ Maximum } & \multirow{2}{*}{$\begin{array}{c}\text { On-road } \\
\text { ratio/FTP ratio }\end{array}$} & \multicolumn{2}{|c|}{ Average } & \multirow{2}{*}{$\begin{array}{c}\text { On-road } \\
\text { ratio/FTP ratio }\end{array}$} \\
\hline & Ratio & bsNOx & & Ratio & bsNOx & \\
\hline SAB2BM & 0.0187 & 12.73 & 1.96 & 0.0139 & 7.334 & 1.46 \\
\hline BM2SAB & 0.0141 & 7.241 & 1.48 & 0.0141 & 6.527 & 1.48 \\
\hline SAB2BM & 0.0192 & 13.52 & 2.02 & 0.0144 & 7.64 & 1.52 \\
\hline $\mathrm{BM} 2 \mathrm{SAB}$ & 0.0178 & 12.10 & 1.87 & 0.0149 & 7.392 & 1.56 \\
\hline PA1 & 0.0141 & 8.722 & 1.48 & 0.012 & 5.851 & 1.26 \\
\hline PA2 & 0.0201 & 10.48 & 2.11 & 0.0147 & 6.808 & 1.54 \\
\hline PA3 & 0.0188 & 9.877 & 1.97 & 0.0142 & 6.844 & 1.49 \\
\hline PA1 & 0.0141 & 7.983 & 1.46 & 0.0125 & 6.110 & 1.31 \\
\hline PA2 & 0.0193 & 13.10 & 2.02 & 0.014 & 7.076 & 1.47 \\
\hline PA3 & 0.0189 & 9.610 & 1.98 & 0.0142 & 6.599 & 1.49 \\
\hline SAB2SW & 0.0139 & 7.381 & 1.46 & 0.0131 & 6.444 & 1.38 \\
\hline SW2SAB & 0.0149 & 7.865 & 1.57 & 0.0128 & 6.370 & 1.34 \\
\hline SAB2SW & 0.0152 & 8.073 & 1.59 & 0.0136 & 6.466 & 1.43 \\
\hline SW2SAB & 0.0167 & 9.017 & 1.75 & 0.0132 & 6.319 & 1.39 \\
\hline
\end{tabular}




\section{CONCLUSIONS AND RECOMMENDATIONS}

\subsection{Conclusions}

This study reflects a portion of the work that was conducted at WVU to satisfy the in-use emissions evaluation as mandated by the Consent Decrees. The Mobile Emissions Measurement System (MEMS) that was developed at WVU was used to measure and record brake-specific emissions from on-road diesel powered engines when operating under actual on-road conditions. The major conclusions of this research are summarized below.

1. The MEMS was successfully used to measure in-use emissions of heavy-duty diesel powered vehicles.

2. The accuracy of brake-specific emissions was affected by various parameters, but measurement of exhaust flow rates was the major source of uncertainty.

3. It has been observed that the cruise mode operation occupies the majority of the engine operation in the NTE region.

4. The brake-specific emissions of $\mathrm{NO}_{\mathrm{x}}$ and $\mathrm{CO}_{2}$ show a strong dependence on the driving modes.

5. The average brake-specific emissions of $\mathrm{NO}_{\mathrm{x}}$ are the highest when the engine operates in the cruise mode, slightly less in the acceleration mode and the least during deceleration.

6. For most cases brake-specific emissions of $\mathrm{NO}_{\mathrm{x}}$ are the highest when the engine speed was about $90-100 \%$ of rated speed. The same was found when the engine load was about $90-100 \%$ of full load conditions.

7. The bsNO ${ }_{x}$ emissions in the NTE region for most cases exceeded the NTE limits. The amount of time the $\mathrm{bsNO}_{\mathrm{x}}$ exceeded the NTE limits varied for each of the routes tested. With the exception of the Bruceton Mills route where the amount of time the bsNO exceeded the NTE limits was approximately $40 \%$, the time spent on other routes ranged from 15 to $20 \%$.

\subsection{Recommendations}

System improvements for the MEMS are being currently considered and some of the improvements are already underway, which are discussed in detail [6].

Emissions are currently reported as an integration of continuous 30s windows of operation in the NTE region. To add diversity, different windows of operation should be 
considered and variations arising from each of them should be studied. Another method would be to average the emissions for the entire period the engine spends in the NTE zone.

The data reduction process was primarily concerned about emissions in the NTE region over continuous $30 \mathrm{~s}$ windows of operation. This was a limiting factor when modal analysis was performed. The reduction program needs to be modified to calculate brake-specific emissions in the non-NTE regions, which would help in better modal analysis.

The fuel used for this testing was commercially available and it has been found that the emissions from fuels obtained from different fuel stations in the Morgantown area produced different results [6]. Methods need to be developed to account for the variation in brake-specific emissions that arise from differences in the fuel properties. 


\section{REFERENCES}

1. "Control of Air Pollution from new motor vehicles: Proposed Heavy-Duty Engine and Vehicle Standards and Highway Diesel Fuel Sulfur Control Requirements," EPA, 40 CFR Parts 69, 80 and 86. June 2, 2000.

2. Code of Federal Regulations, Title 40, Part 86 Subpart N, "Emission Regulations for New Otto-Cycle and Diesel Heavy-Duty Engines; Gaseous and Particulate Exhaust Test Procedures", Washington D.C, 1998.

3. Gautam, M., Clark, N. N., Thompson, G. J., Carder, D. K., and Lyons, D. W. (2000), "Evaluation of Mobile Monitoring Technologies for Heavy-Duty Diesel-Powered Vehicle Emissions," Phase I Report, Submitted to the Settling Heavy-Duty Diesel Engine Manufacturers by West Virginia University, Morgantown, WV, March 2000.

4. Gautam, M., Clark, N. N., Thompson, G. J., Carder, D. K., and Lyons, D. W. (2000), "Development of In-Use Testing Procedures for Heavy-Duty Diesel-Powered Vehicle Emissions," Phase II Report, Submitted to the Settling Heavy-Duty Diesel Engine Manufacturers by West Virginia University, Morgantown, WV, March 2000.

5. Gautam, M., Clark, N. N., Thompson, G. J., Carder, D. K., and Lyons, D. W. (2000), "Evaluation of In-Use Heavy-Duty Vehicle Emissions Using the Mobile Emissions Measurement System (MEMS)," Phase III Report, Submitted to the Settling Heavy-Duty Diesel Engine Manufacturers by West Virginia University, Morgantown, WV, December 2002.

6. Gibble, J. C., "Comparison of Heavy-Duty Diesel Engine Emissions Between an OnRoad Route and Engine Dynamometer Simulated On-Road Cycle", M.S Thesis, Department of Mechanical and Aerospace Engineering, West Virginia University, Morgantown, WV, 2003.

7. Emissions Standards: USA - Heavy Duty Truck and Bus Engines, www.dieselnet.com EcoPoint Inc., May 2003.

8. Frey, H. C., Unal, A., Rouphall, N. M., Colyar, J. D. "On-Road Measurement of Vehicle Tailpipe Emissions Using a Portable Instrument," Journal of the Air \& Waste Management Association, Volume 53, 992-1002, August, 2003. 
9. "Notice of Filing of Consent Decree under the Clean Air Act," Federal Register, Vol 63, No. 212, Office of the Federal Register, National Archives and Records Administration, Washington D.C, November 3, 1998.

10. Thompson, G., Gautam, M., Clark, N., and Lyons, D., "Inference of Torque and Power From Heavy-Duty Diesel Engines for On-Road Emissions Monitoring," SAE Technical Paper No. 2002-01-0614, 2002.

11. Branstetter, R., Burrahm, R., and Dietzmann, H., "Relationship of Underground Diesel Engine Maintenance to Emissions, “Final Report for 1978 to 1983 to the U.S. Bureau of Mines, Department of Interior Contract H0292009, 1983.

12. Chan, L., Carlson, D. H., and Johnson, J. H., "Evaluation and Application of a Portable Tailpipe Emissions Measurement Apparatus for Field Use”, SAE Technical Paper No. $921647,1992$.

13. Spears, M. W., “An Emissions-Assisted Maintenance Procedure for Diesel-Powered Equipment," University of Minnesota, Center for Diesel Research, Minneapolis, MN, 1997.

14. Englund, M. S., "Field Compatible $\mathrm{NO}_{\mathrm{x}}$ Emission Measurement Technique," SAE Technical Paper No. 820647, 1982.

15. Human, D. M., and Ullman, T. L., "Development of an I/M Short Emissions Test for Buses, “ SAE Technical Paper No. 920727, 1992.

16. Kelly, N. A., and Groblicki, P. J., "Real-world emissions from a modern production vehicle driven in Los Angeles," Journal of the Air and Waste Management Association, Volume 43, 1351-1357, July, 1993.

17. Bentz, A. P, and Weaver, E., "Marine Diesel Exhaust Emissions Measured By Portable Instruments," SAE Technical Paper No. 941784, 1994.

18. Bruneel, H., "Heavy Duty Testing Cycles Development: a New Methodology", SAE Technical Paper No. 2000-01-1860, 2000.

19. "Construction Equipment Retrofit Project" Northeast States for Coordinated Air Use Management, Boston, MA, 1998.

20. Butler, J. W. Korinski, T.J., Reading, A. R., and Kotenko, T. L, "Dynamometer Quality Data On-Board Vehicles for Real-World Emissions Measurements," Proceedings of the Ninth CRC On-Road Vehicle Workshop, April 19-21, San Diego, CA, 1999. 
21. Vojtisek-Lom, M., and Cobb, J. T., "Measuring On-Road Heavy-Duty Vehicle Emissions using a Portable On-Board System," Proceedings of the Ninth CRC On-Road Vehicle Workshop, April 19-21, San Diego, CA, 1999.

22. Vojtisek-Lom, M., and Cobb, J. T., "On-Road Light-Duty Vehicle Mass Emission Measurements using a Novel Inexpensive On-Board Portable System," Proceedings of the Ninth CRC On-Road Vehicle Workshop, April 20-22, San Diego, CA, 1998.

23. Scarbro, C. “ An Investigation of Rover's Capabilities to Accurately Measure the In-use Activity and Emissions of Late-Model Diesel and Gasoline Trucks" Proceedings of the $10^{\text {th }}$ CRC On-Road Vehicle Emissions Workshop, San Diego, CA; Coordinating Research Council: Atlanta, GA, 2000.

24. Jetter, J., Maeshiro, S., Hatcho, S., and Klebba, R., "Development of An On-Board Analyzer for Use on Advanced Low-Emission Vehicles," SAE Technical Paper No. 2000-01-1140, 2000.

25. Reading, A., "Technical Advances in Portable Emission Measurement Systems", Proceedings of the Government/Industry Meeting, Washington D.C., May 12-14, 2003.

26. Miyazaki, T., Takada, Y., and Lida, N., "Development of On-Board System to Measure Running Condition and Actual $\mathrm{NO}_{\mathrm{x}}$ Emissions From Freight Vehicle," SAE Technical Paper No. 2002-01-0613, 2002.

27. Hawirko, J. D., and Checkel, D. M., "Real-Time, On-Road Measurement of Driving Behavior, Engine Parameters and Exhaust Emissions," SAE Technical Paper No. 200201-1714, 2002.

28. Nakamura, H., Kihara, H., Adachi, M., and Ishida, K., "Development of a Wet-Based NDIR and Its Application to On-Board Emission Measurement System," SAE Technical Paper No. 2002-01-0612, 2002.

29. Kihara, N., Tsukamoto, T., Matsumoto, K., Ishida, K., Kon, M., and Murase, T., "RealTime, On-Board Measurement of Mass Emission of $\mathrm{NO}_{\mathrm{x}}$, Fuel Consumption, Road Load, and Engine Output for Diesel Vehicles," SAE Technical Paper No. 2000-01-1141, 2000.

30. Pankratz, D., Johnson, K.C, Smith, M.R, Welch, W.A., Norbeck, J.M, "Develop OnRoad System for Emissions Measurement from Heavy-Duty Trucks," Final Report submitted to South Coast Air Quality Management District, Diamond Bar, CA, May 31, 2001. 
31. Miller, J. W., Cocker, D., Johnson, K.C., Park, C. S., Welch, W. A., Norbeck, J. M., "Use of a Mobile Laboratory to Measure HDD Real World Emissions from a Number of Standard and Non-Standard Cycles," Proceeding of the 12th CRC On-Road Vehicle Emissions Workshop, San Diego, CA, April 15-17, 2002.

32. Miller, J. W., Cocker, D., Johnson, K.C.,Shah, S., Norbeck, J. M., "Measuring 'Real World' Heavy-Duty Diesel Emissions with a Mobile Lab," Proceedings of the 8th Diesel Engine Emissions Reduction (DEER) Conference. San Diego, CA, August 29, 2002.

33. Thompson, G., Gautam, M., Clark, N., Carder, D. K., Riddle, W., Shade, B., and Lyons, D., "Measurement of In-Use, On-Board Emissions From Heavy-Duty Diesel Vehicles: Mobile Emissions Measurement System," SAE Technical Paper No. 2001-01-3643, 2001.

34. Czachura, B., Brandon, L., May, Al., "Demonstration of the "Simple, Portable, OnVehicle Testing' (SPOT) System on a Class 8 Vehicle", Proceedings of the $11^{\text {th }}$ On-road Vehicle Emissions Workshop, San Diego, CA, 2001.

35. Jimenez, J. L., Mcrae, G. J., Nelson, D. D., Zahniser, M. S., and Kolb, C. E., “ Final Report: Remote Sensing of $\mathrm{NO}$ and $\mathrm{NO}_{2}$ Emissions from Heavy-Duty Diesel Trucks Using Tunable Diode Lasers," National Center for Environmental Research, EPA Grant No. R824794, 1998.

36. Weaver, C. S., and Balam-Almanza, M. V., "Development of the "RAVEM" Ride-Along Vehicle Emission Measurement System for Gaseous and Particulate Emissions," SAE Technical Paper No. 2001-01-3644, 2001.

37. Weaver, C. S., Chan, L. and Peety, L. "Measurement of Air Pollutant Emissions From InService Passenger Ferries" Engine, Fuel and Emissions Engineering, Inc., Emissions data report submitted to San Francisco Bay Area Water Transit Authority, 2002.

38. Vojtisek-Lom, M., Lambert, D. C., Wilson, J., "Real-World Emissions From 40 HeavyDuty Diesel Trucks Recruited At Tulare, CA, Rest Area," SAE Technical Paper No. 2002-01-2901, 2002.

39. Vojtisek-Lom, M., and Allsop, J. E., "Development of Heavy-Duty Diesel Portable, OnBoard Mass Exhaust Emissions Monitoring System With $\mathrm{NO}_{\mathrm{x}}, \mathrm{CO}_{2}$ and Qualitative $\mathrm{PM}$ Capabilities," SAE Technical Paper No. 2001-01-3641, 2001. 
40. King, G. F., Mitchell, W. C., Squier, W. C., Harris, B. D., Kinsey, J. S. "On-Road Facility to Measure and Characterize Emissions from Heavy-Duty Diesel Vehicles", Journal of the Air \& Waste Management Association, Volume 52, 388-395, April, 2002.

41. "Diamond II+ Annubar Flow Element- Product Data sheet-00813-0100-4760, DS-4009" Dietrich Standard Inc., Boulder, CO, 80301.

42. "Garmin, GPS 35 LP TracPak, Technical Specifications," Garmin, Olathe, Kansas, 66062. See http://www.garmin.com/products/gps35/spec.htm1

43. "Thin Film Voltage Output Pressure Sensor Specifications," Omega Engineering Inc., Stamford, Conn, 06907. See http://www.omega.com/Pressure/pdf/PX203.pdf

44. "P55 Compact Differential Pressure Transducer- Specifications," Validyne Engineering Corp., Northridge, CA, 91324. See http://www.validyne.com/main.html

45. "Relative Humidity Transducer Specifications," Omega Engineering Inc., Stamford, Conn, 06907. See http://www.omega.com/Temperature/pdf/HX92.pdf.

46. "Standard Practice for Maintaining Constant Relative Humidity by Means of Aqueous Solutions," ASTM Document No. E104-85, 1985.

47. Kata, N. “Thick Film $\mathrm{ZrO}_{2} \mathrm{NO}_{\mathrm{x}}$ Sensor”, SAE Technical Paper Series, 90334, 1996.

48. Kobayashi, N., Yamashita, A., Naito, O., Setoguchi, T., Murase, T. "Development of Simultaneous $\mathrm{NO}_{\mathrm{x}} / \mathrm{NH}_{3}$ Sensor in Exhaust Gas", Mitsubishi Heavy Industries, Ltd. Technical Review Vol.38 No.3, October 2001.

49. Thompson, G., Gautam, M., Clark, N., Carder, D. K., Riddle, W., Shade, B., and Lyons, D., "Measurement of Brake-Specific $\mathrm{NO}_{\mathrm{x}}$ Emissions Using Zirconia Sensors for In- Use, On-Board Heavy-Duty Vehicle Applications,” SAE Technical Paper No. 2002-01-1755.

50. Riddle, W.C., "Design and Evaluation of the Emissions Measurement Components for a Heavy-Duty Diesel Powered Vehicle Mobile Emissions Measurement System (MEMS)”, M.S Thesis, Department of Mechanical and Aerospace Engineering, West Virginia University, Morgantown, WV, 2001.

51. Strehlow R. A., "FUNDAMENTALS OF COMBUSTION", International Textbook Company.

52. Narasimhamurthy, P.R., "Investigation of Techniques to improve Measurement Accuracy of $\mathrm{NO}, \mathrm{NO}_{2}$, and $\mathrm{NO}_{\mathrm{x}}$ Emissions from Heavy-Duty Diesel Engines", M.S Thesis, 
Department of Mechanical and Aerospace Engineering, West Virginia University, Morgantown, WV, 2002.

53. Gluck, S., Glenn, Chuck., Logan, T., Vu, Bac., Walsh, M., Williams, P. "Evaluation of $\mathrm{NO}_{\mathrm{x}}$ Flue Gas Analyzers for Accuracy and Their Applicability for Low-Concentration Measurements", Journal of the Air \& Waste Management Association, Volume 53, 749758, June 2003.

54. Taylor, N. B., Kuyatt, E. C. "Guidelines for Evaluating and Expressing the Uncertainty of NIST Measurement Results", National Institute of Standards and Technology, Technical Note 1297, 1994.

55. "Test Uncertainty", The American Society of Mechanical Engineers, ASME PTC 19.1, 1998.

56. Velosa, J. "Error Analysis of the Vehicle Exhaust Emission Measurement System", SAE Technical Paper No. 930393, 1993.

57. Sierens, R., Rosseel, E., "The Physical and the Chemical Part of the Ignition Delay in Diesel Engines," SAE Technical Paper No. 961123.

58. Uludogan, A.D, Foster, D.E., Reitz, R. D " Modelling the Effect of Engine Speed on the Combustion Process and Emissions in a DI Diesel Engine," SAE Technical Paper No. 962056.

59. Shade, B.C., “ A Performance Evaluation of the MEMS- An On-Road Emissions Measurement System Study", M.S Thesis, Department of Mechanical and Aerospace Engineering, West Virginia University, Morgantown, WV, 2000.

60. Cooper, C. and Rideout, G. R., "The Impact of Retrofit Exhaust Control Technologies on Emissions From Heavy-Duty Diesel Construction Equipment," SAE Technical Paper No. 1999-01-0110. 
APPENDIX A

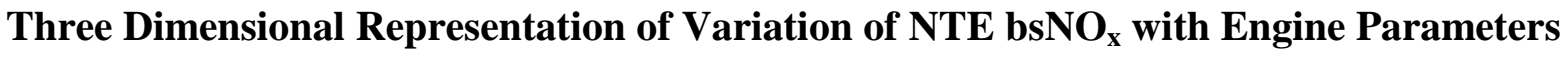
(Class 8 Tractor, 435hp, $1550 \mathrm{ft}-\mathrm{lb} @ 1700$ RPM, MY1996) 


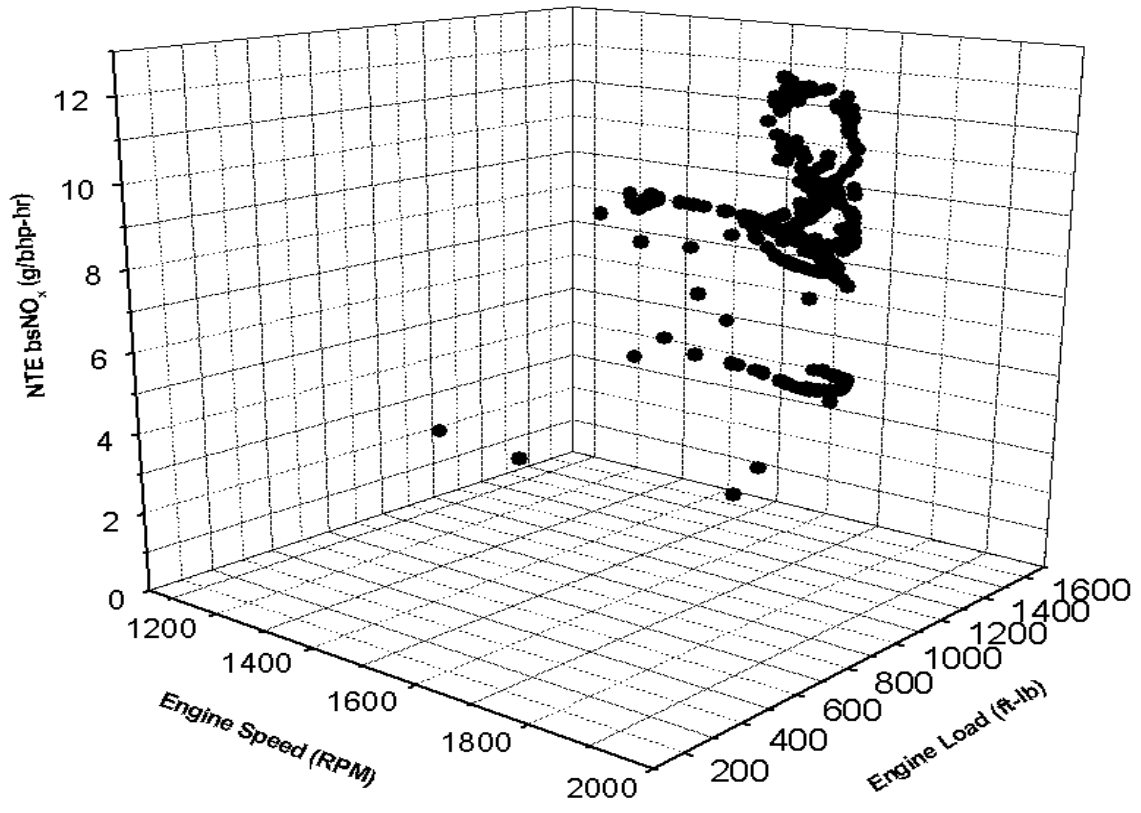

Figure A-1 Three-dimensional representation of variation of NTE bsNO$_{x}$ as function of engine speed and engine torque for a SAB2BM route.

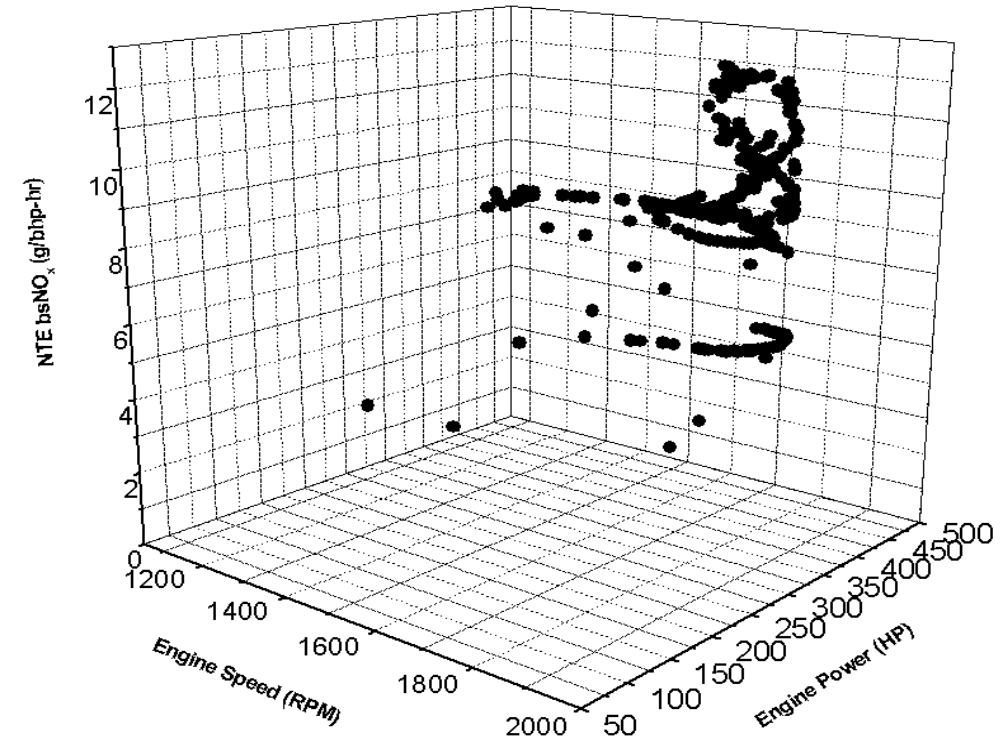

Figure A-2 Three-dimensional representation of variation of NTE $b \mathrm{NO}_{\mathrm{x}}$ as function of engine speed and engine power for a SAB2BM route. 


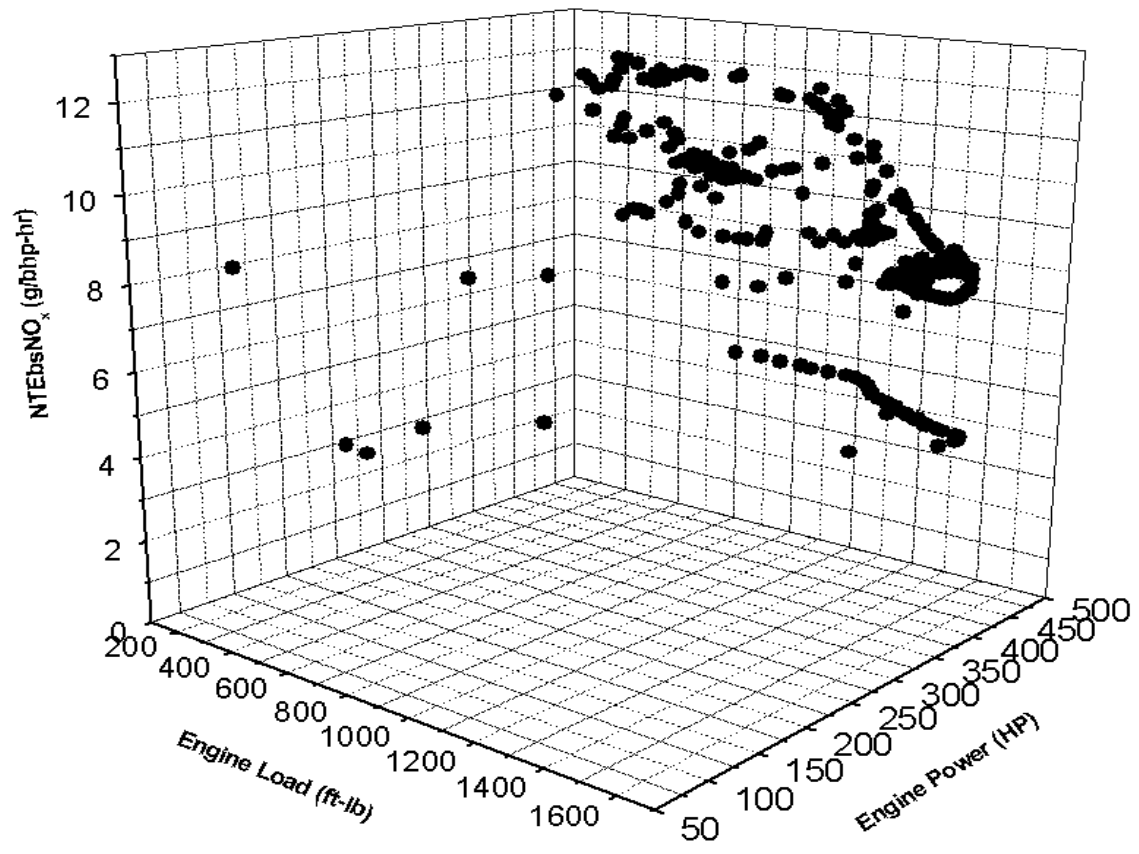

Figure A-3 Three-dimensional representation of variation of NTE bsNO$_{x}$ as function of engine load and engine power for a SAB2BM route.

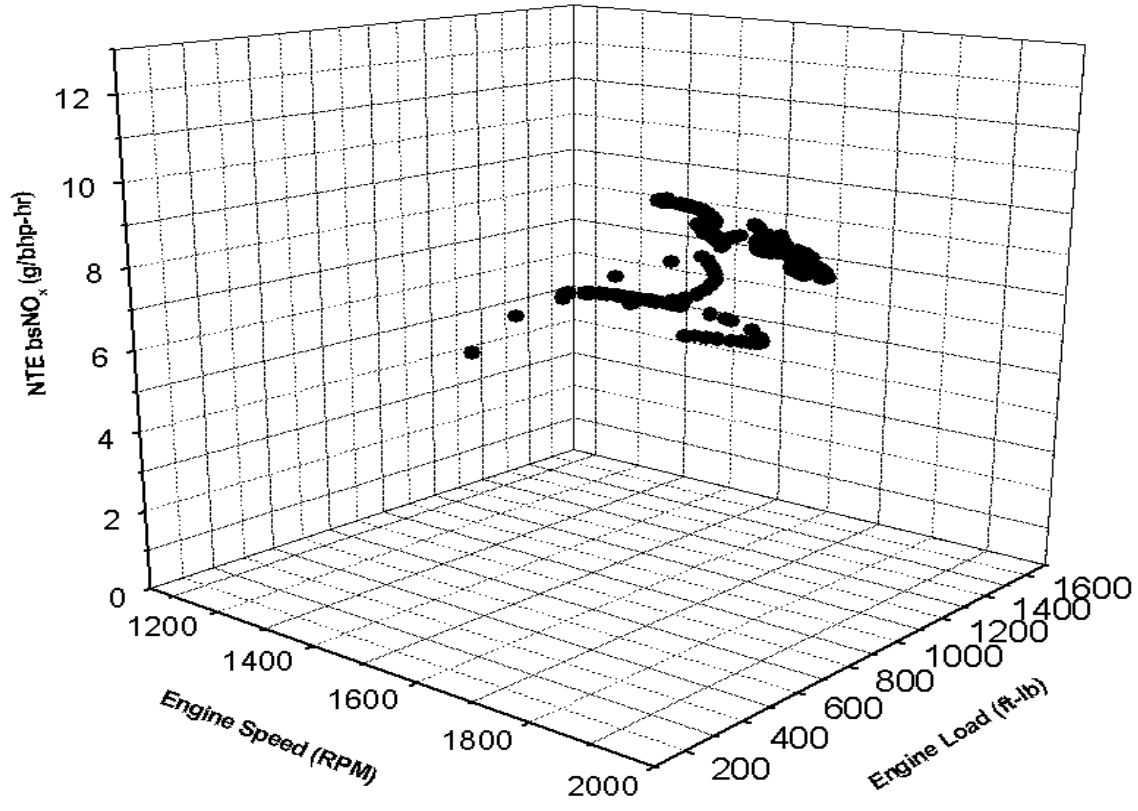

Figure A-4 Three-dimensional representation of variation of NTE bsNO$_{x}$ as function of engine speed and engine load for a BM2SAB route. 


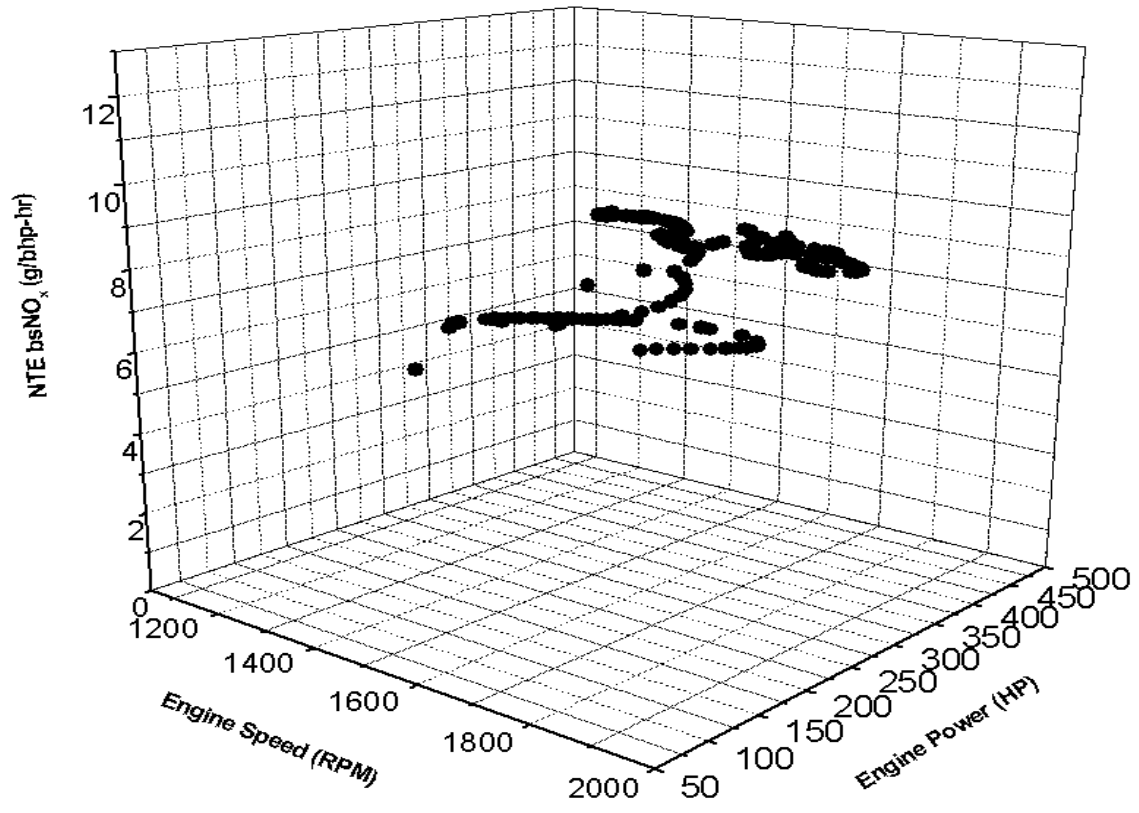

Figure A-5 Three-dimensional representation of variation of NTE bsNO$_{x}$ as function of engine speed and engine power for a BM2SAB route.

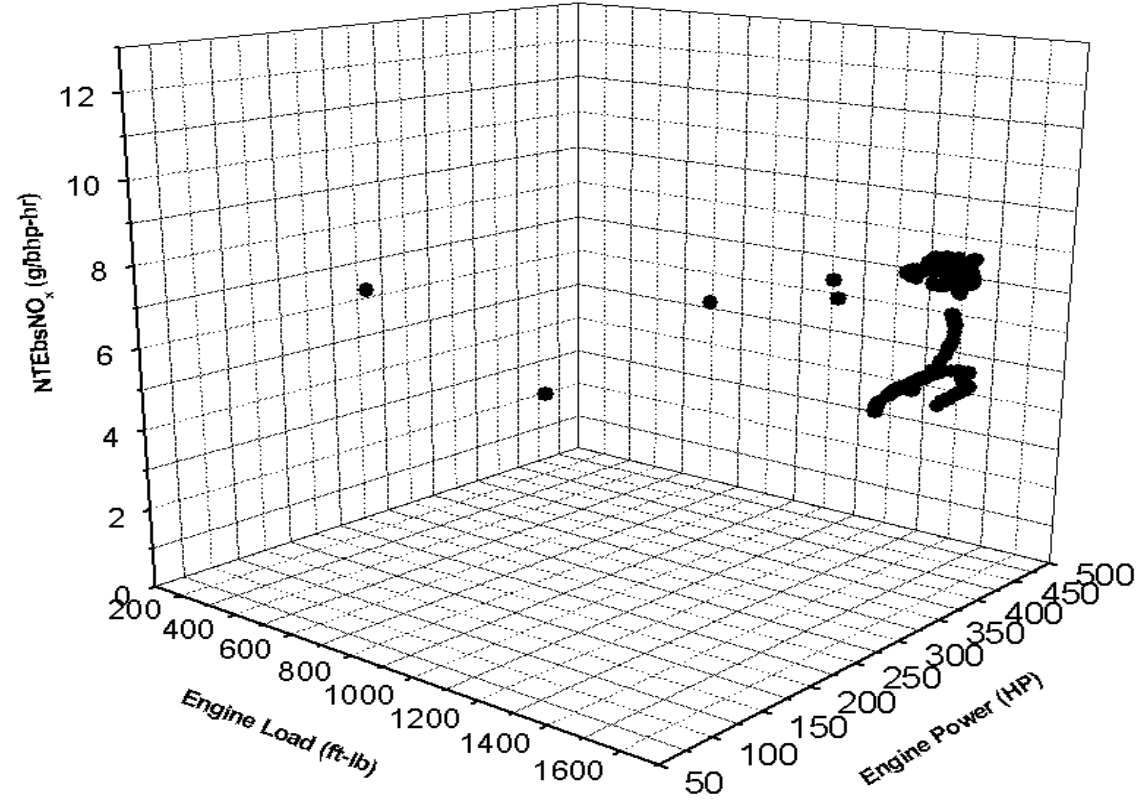

Figure A-6 Three-dimensional representation of variation of NTE bsNO $_{x}$ as function of engine load and engine power for a BM2SAB route. 


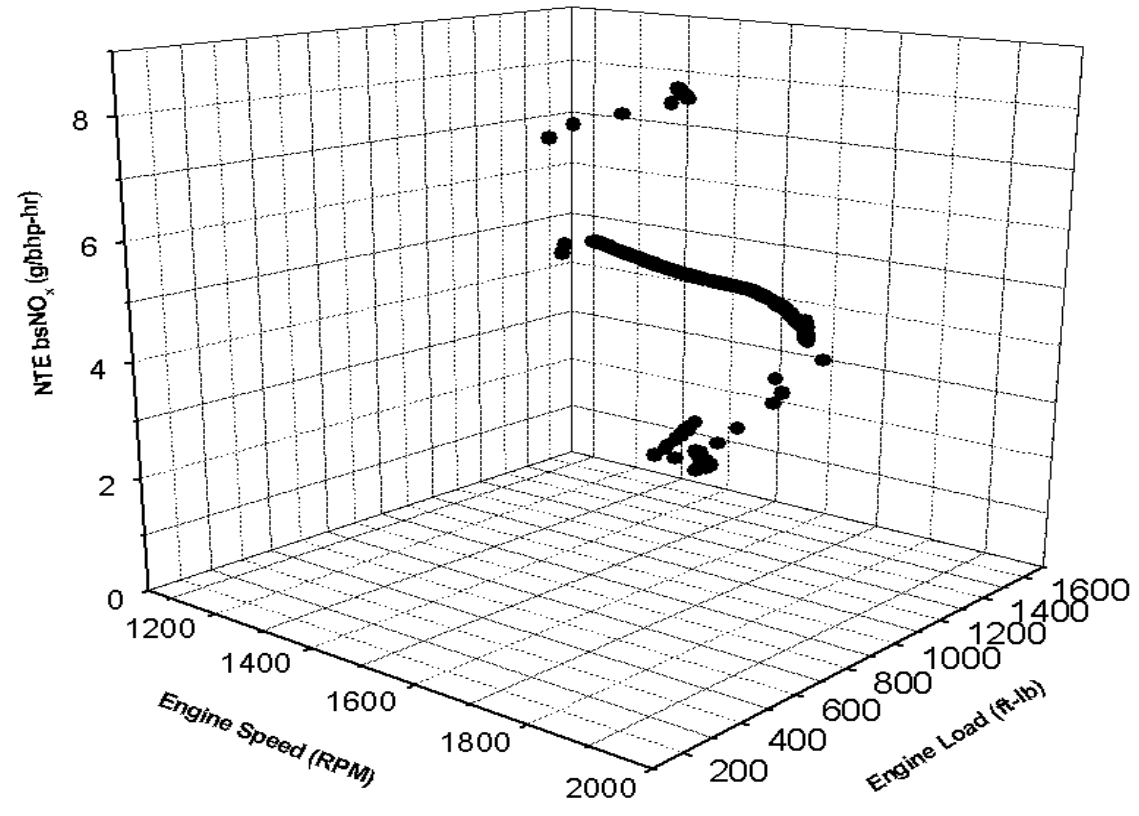

Figure A-7 Three-dimensional representation of variation of NTE bsNO$_{x}$ as function of engine speed and engine load for a PA1 route.

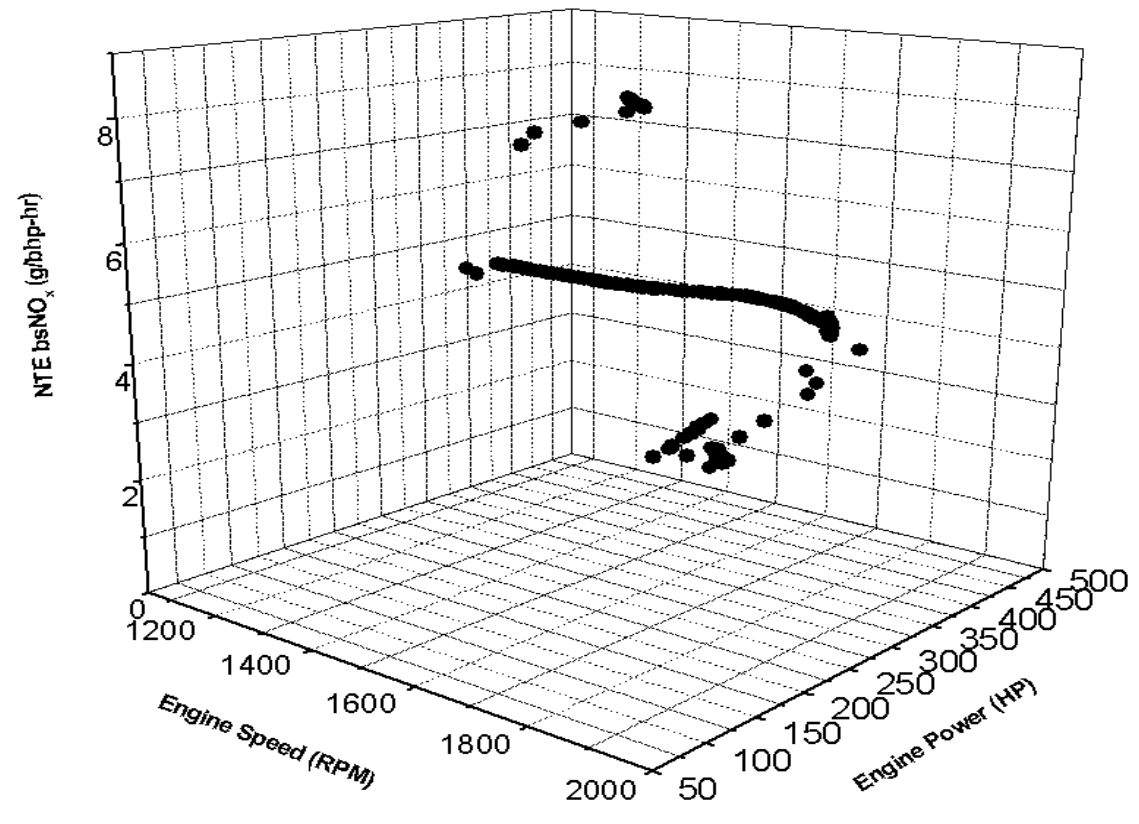

Figure A-8 Three-dimensional representation of variation of NTE bsNO$_{x}$ as function of engine speed and engine power for a PA1 route. 


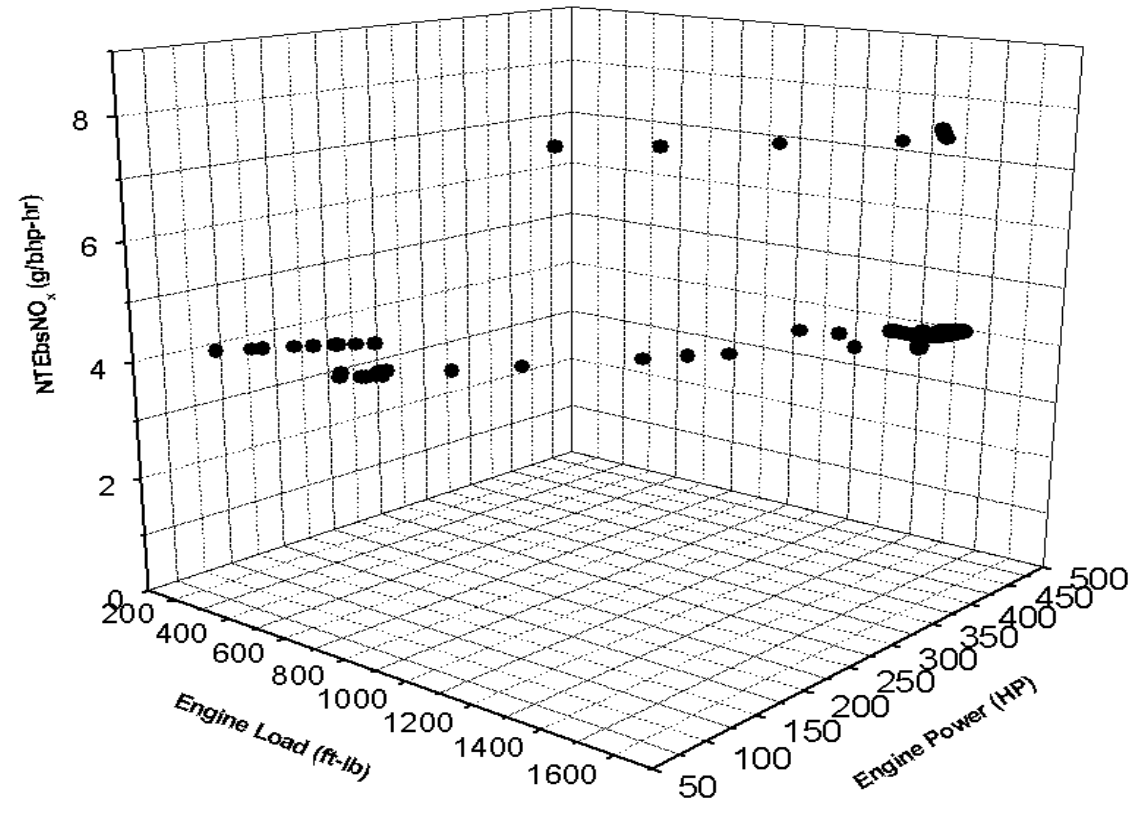

Figure A-9 Three-dimensional representation of variation of $\mathrm{NTE}_{\mathrm{bsNO}}$ as function of engine load and engine power for a PA1 route.

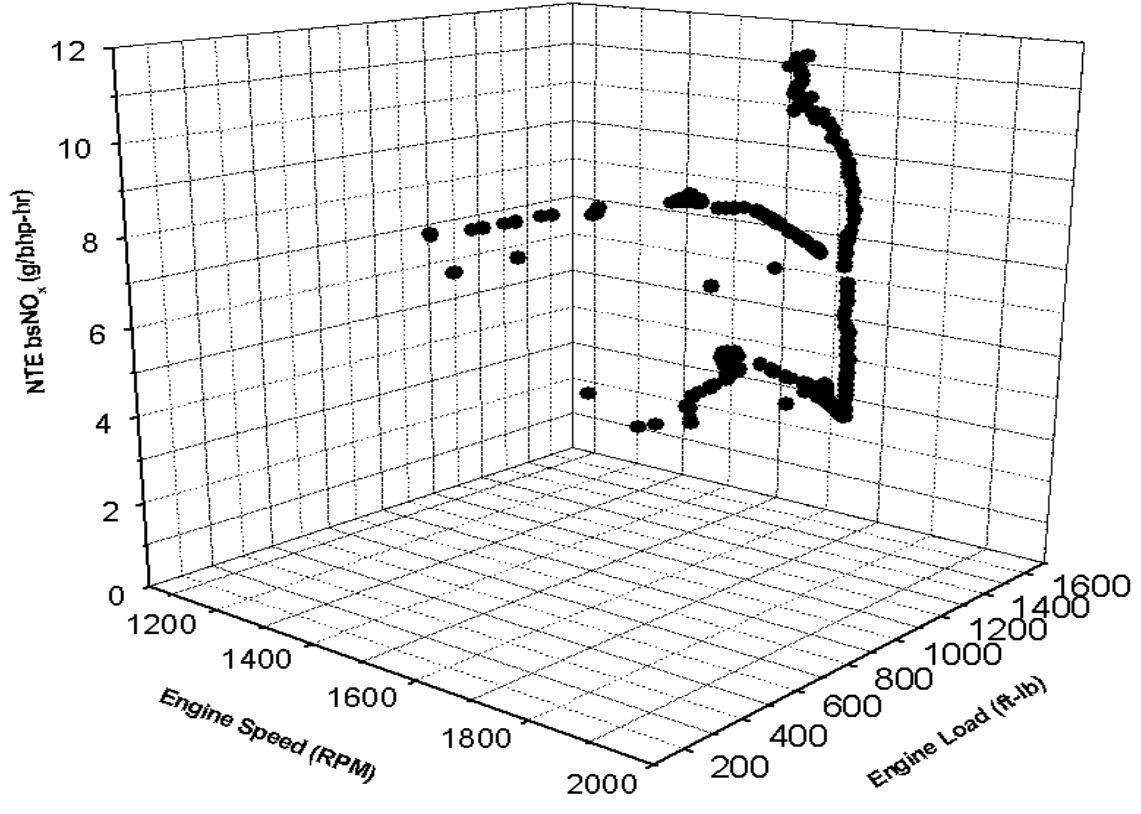

Figure A-10 Three-dimensional representation of variation of NTE bsNO$_{x}$ as function of engine speed and engine load for a PA2 route. 


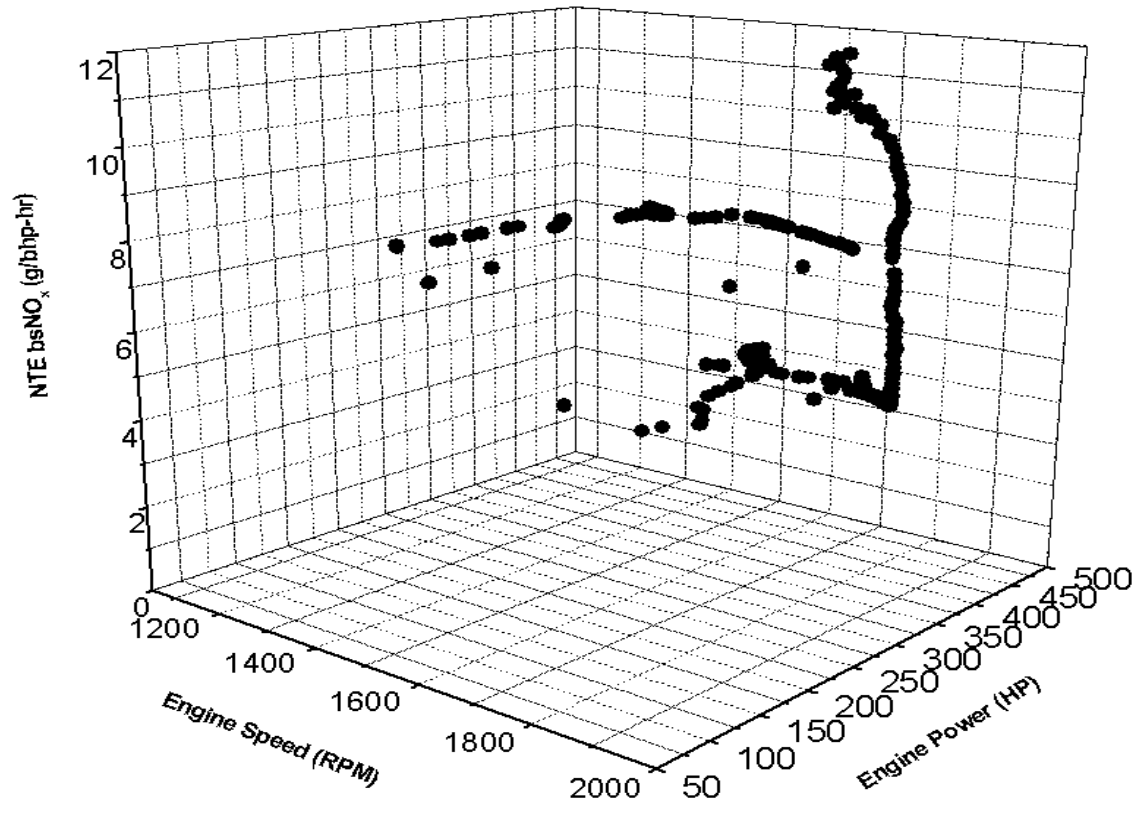

Figure A-11 Three-dimensional representation of variation of NTE bsNO$_{x}$ as function of engine speed and engine power for a PA2 route.

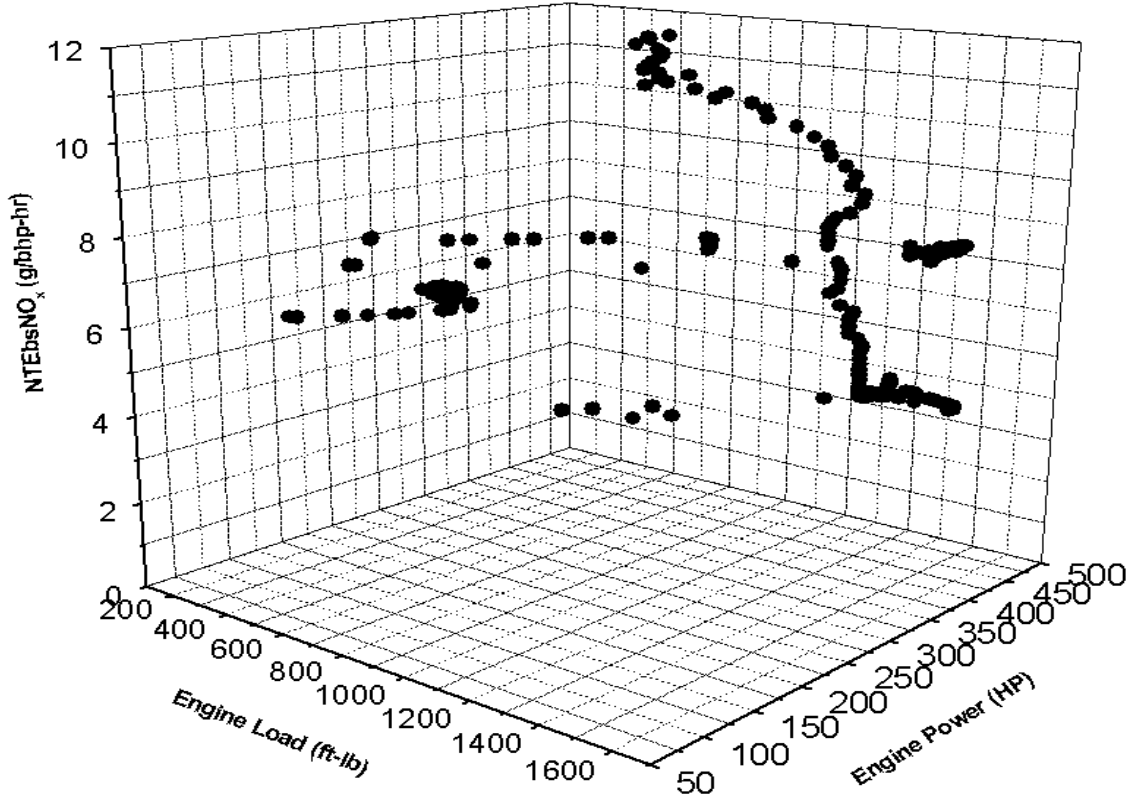

Figure A-12 Three-dimensional representation of variation of NTE bsNO$_{x}$ as function of engine load and engine power for a PA2 route. 


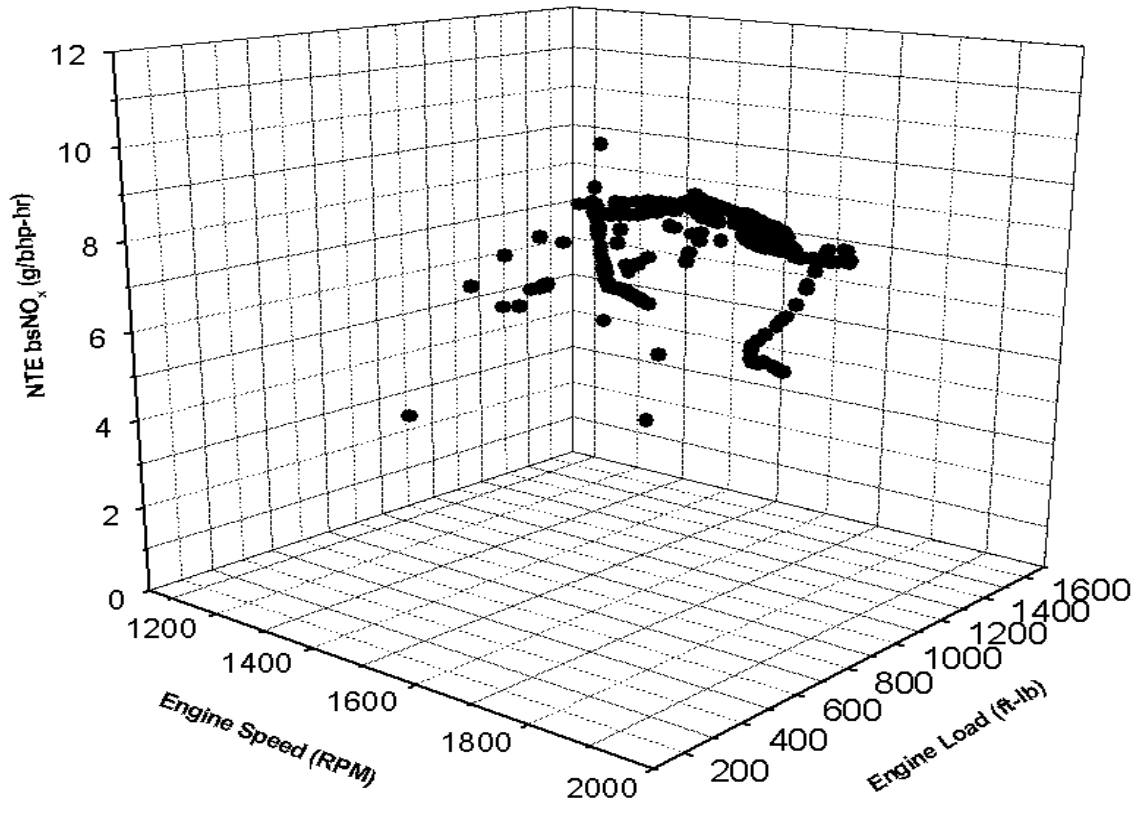

Figure A-13 Three-dimensional representation of variation of NTE bsNO$_{x}$ as function of engine speed and engine load for a PA3 route.

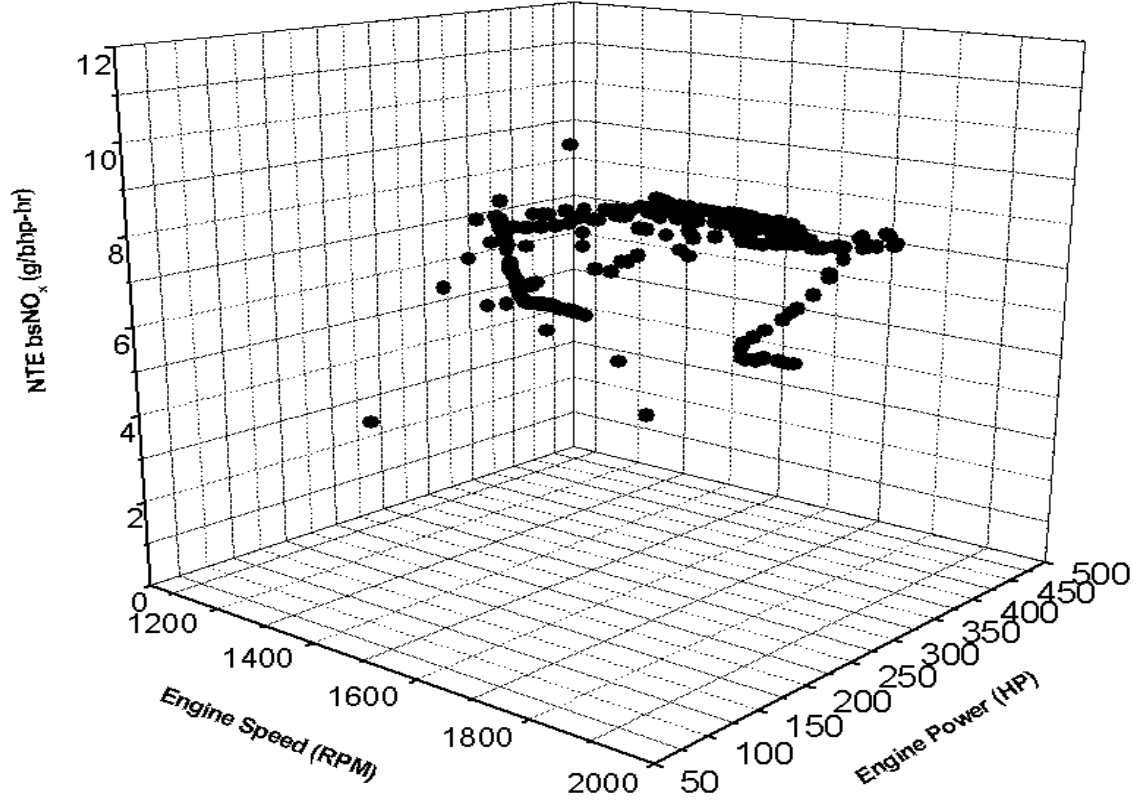

Figure A-14 Three-dimensional representation of variation of NTE $b \mathrm{NO}_{\mathrm{x}}$ as function of engine speed and engine power for a PA3 route. 


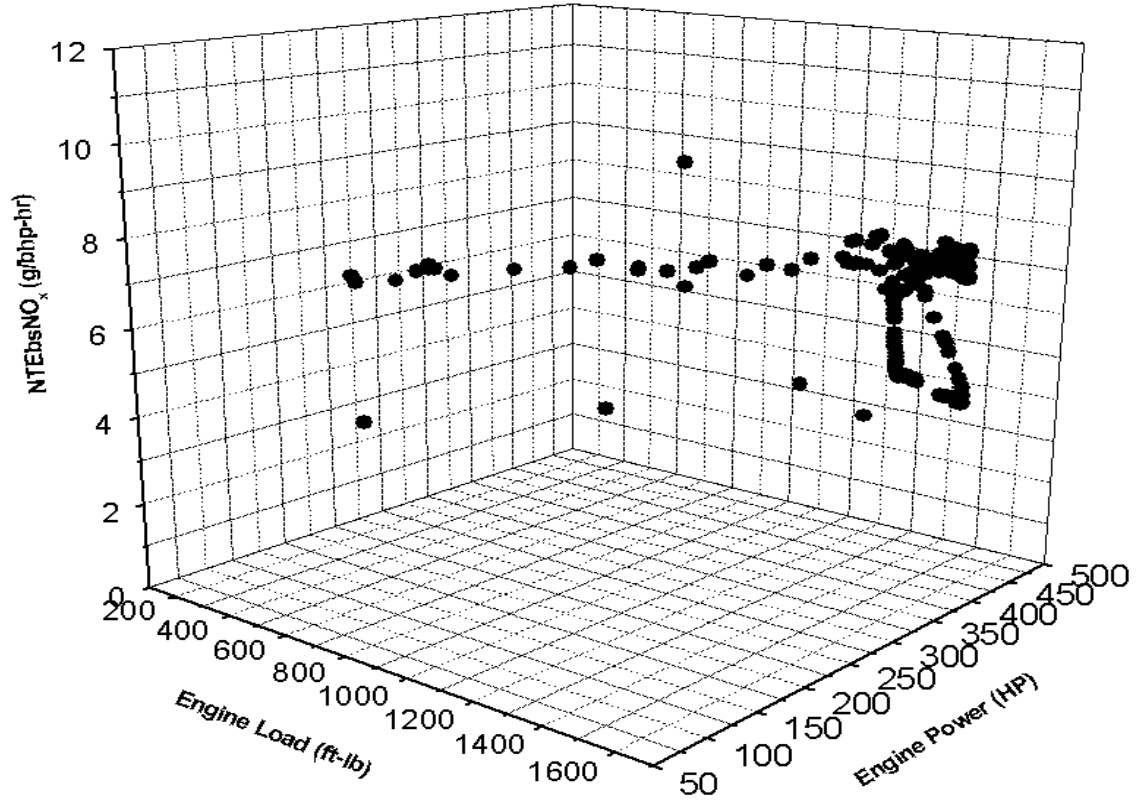

Figure A-15 Three-dimensional representation of variation of NTE bsNO$_{x}$ as function of engine load and engine power for a PA3 route.

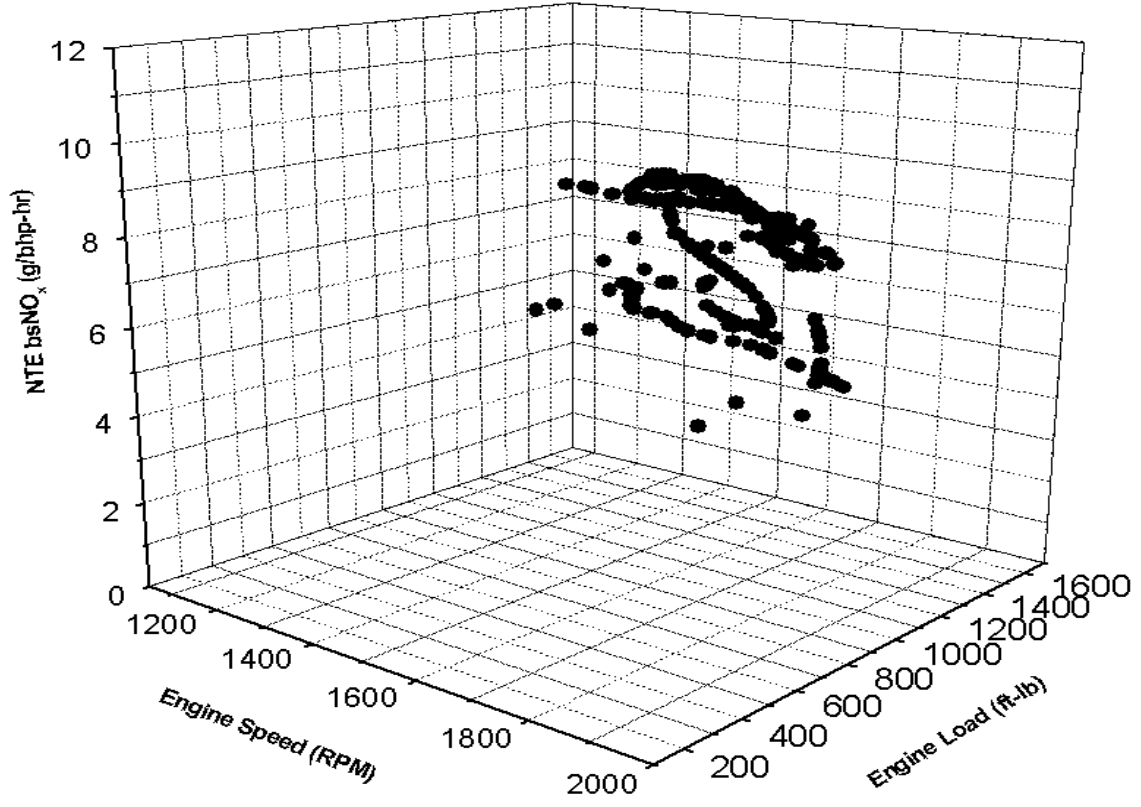

Figure A-16 Three-dimensional representation of variation of NTE bsNO$_{x}$ as function of engine speed and engine power for a SAB2SW route. 


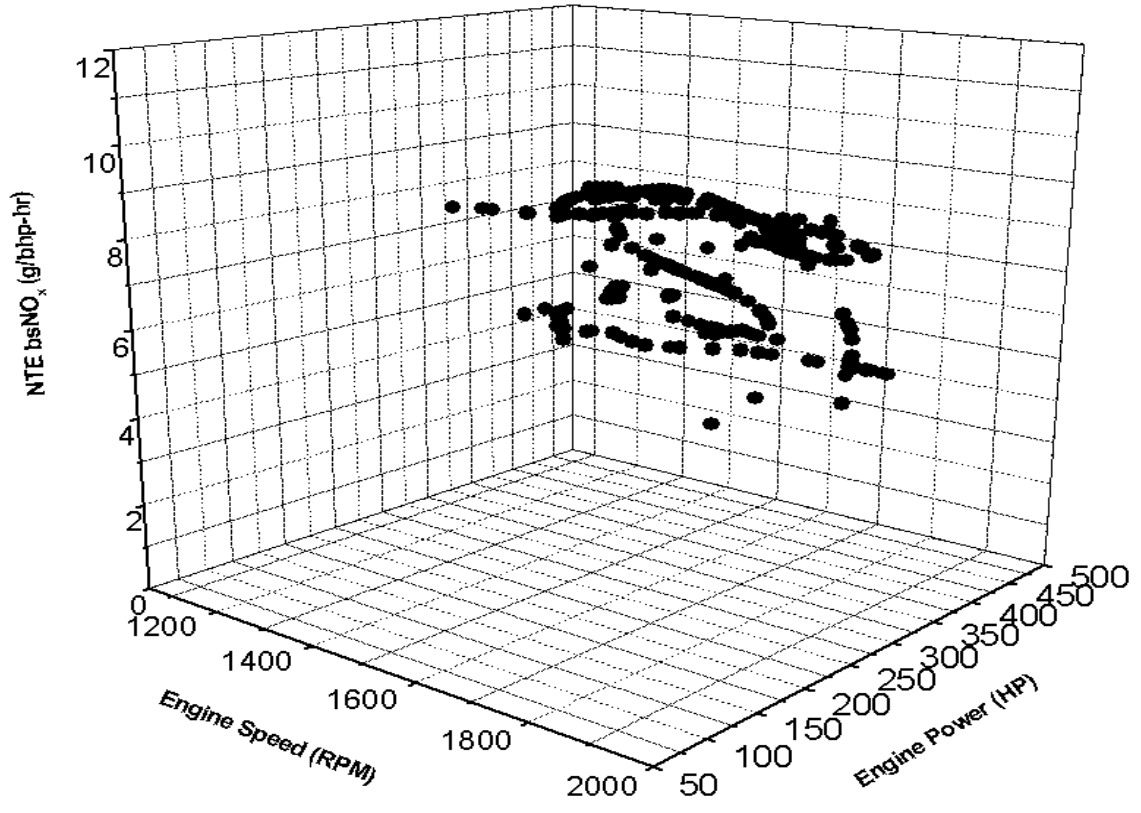

Figure A-17 Three-dimensional representation of variation of NTE bsNO$_{x}$ as function of engine speed and engine power for a SAB2SW route.

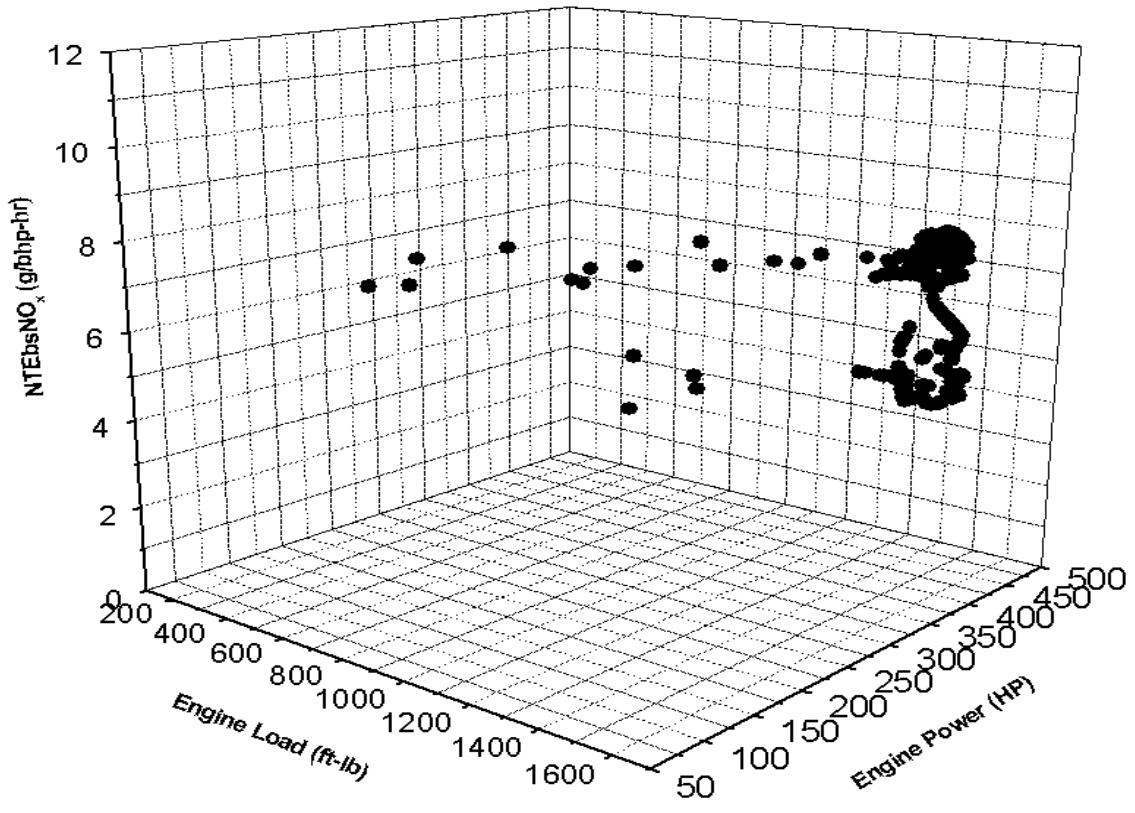

Figure A-18 Three-dimensional representation of variation of NTE bsNO$_{x}$ as function of engine load and engine power for a SAB2SW route. 


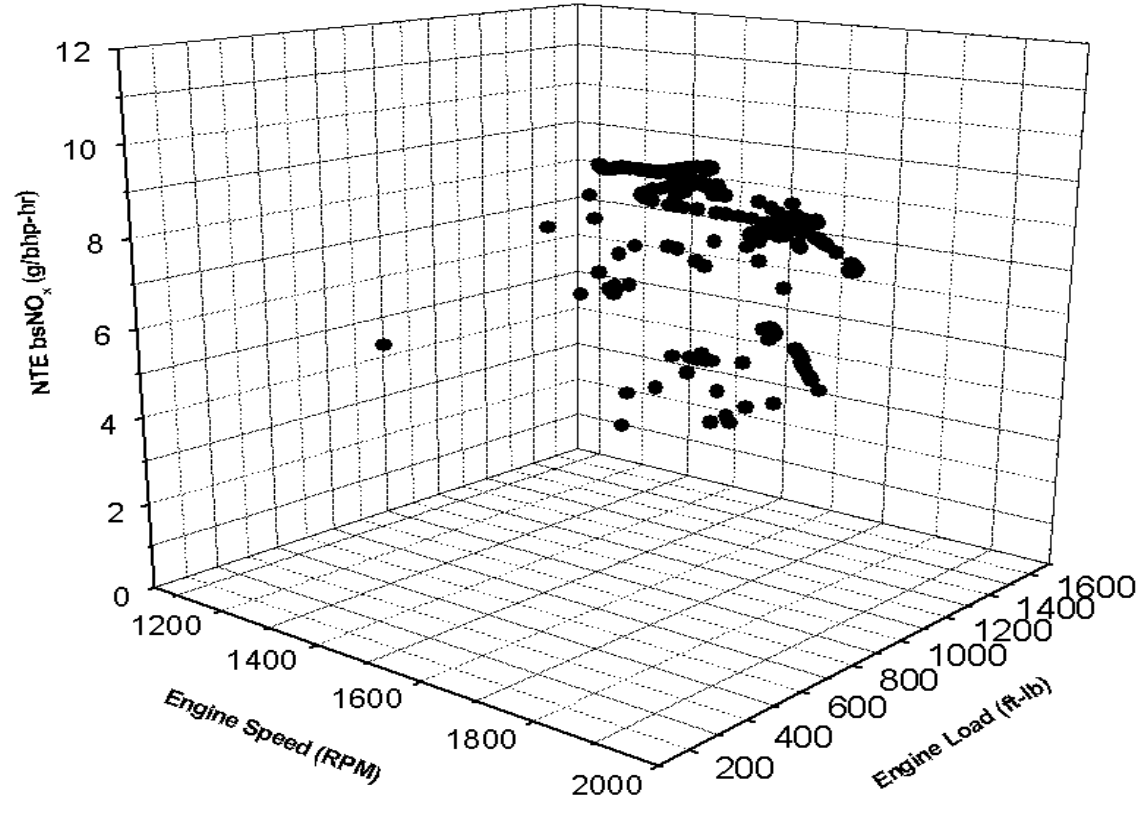

Figure A-19 Three-dimensional representation of variation of NTE bsNO$_{x}$ as function of engine speed and engine power for a SW2SAB route.

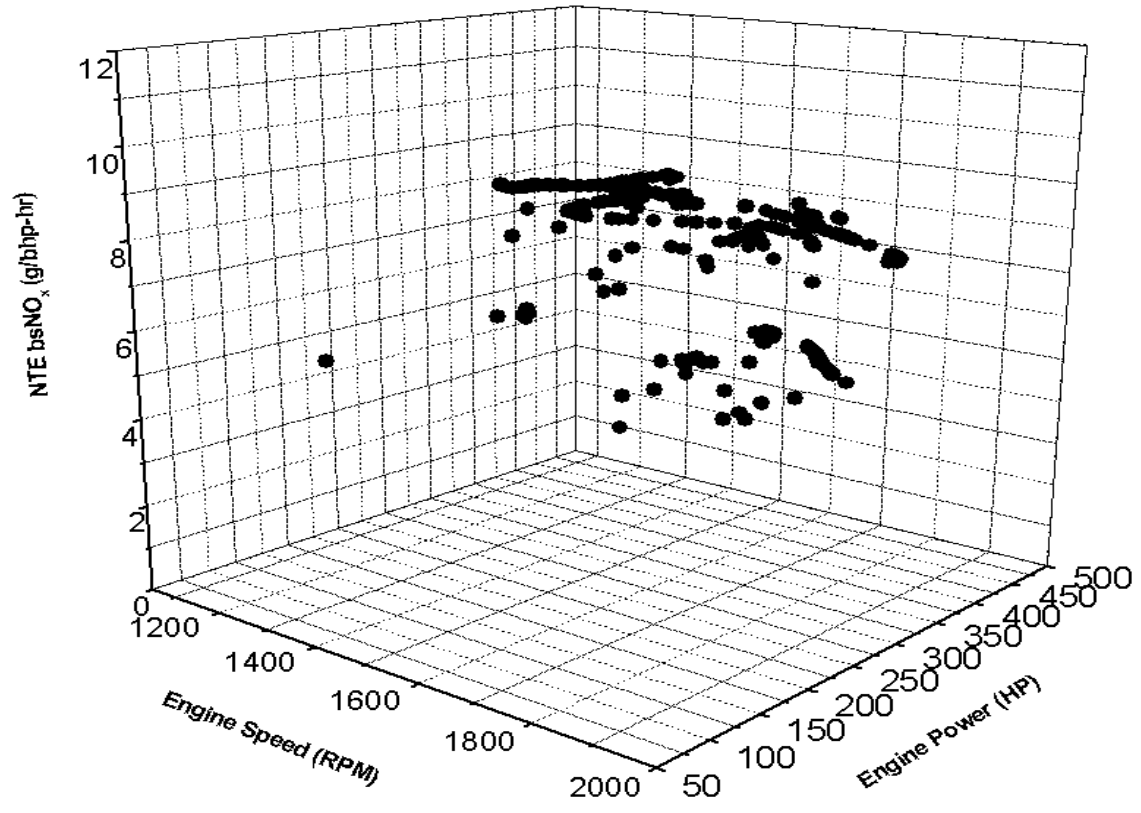

Figure A-20 Three-dimensional representation of variation of NTE bsNO$_{x}$ as function of engine speed and engine power for a SW2SAB route. 


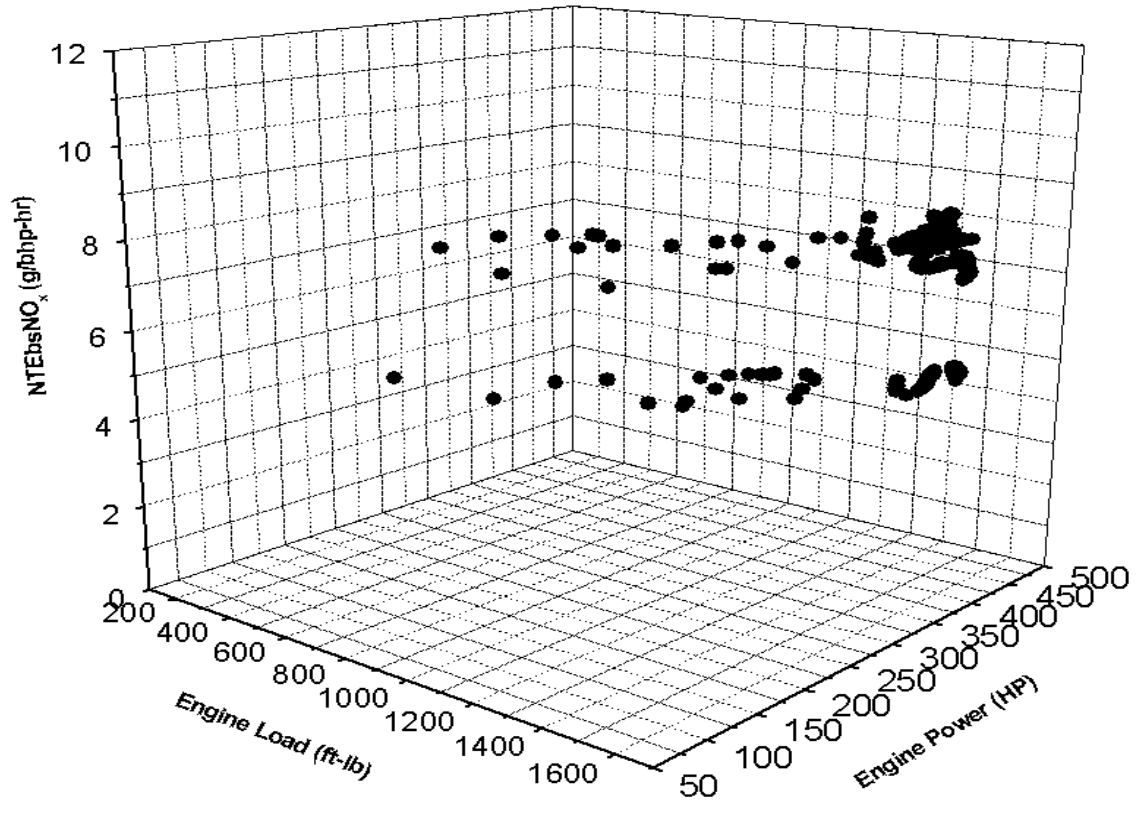

Figure A-21 Three-dimensional representation of variation of NTE bsNO$_{x}$ as function of engine load and engine power for a SW2SAB route. 
APPENDIX B

Baseline $\mathrm{NO}_{\mathrm{x}} / \mathrm{CO}_{2}$ Ratios for Different Model Year Engines from SHDDE Manufacturers 
Table B-1 Baseline $\mathrm{NO}_{\mathrm{x}} / \mathrm{CO}_{2}$ calculations for a $\mathrm{MY} 1996$ engine

\begin{tabular}{|c|c|c|c|c|c|c|}
\hline \multicolumn{7}{|c|}{ Engine Model Year 1996} \\
\hline \multicolumn{2}{|c|}{ Allowed FTP bsNOx } & 5.0000 & & & & \\
\hline \multicolumn{2}{|c|}{ Allowed FTP bsCO2 } & 500.00 & & & & \\
\hline \multicolumn{2}{|c|}{ FTP Ratio } & 0.01000 & & & & \\
\hline \multicolumn{2}{|c|}{ Allowed NTE bsNOx } & 6.2500 & & & & \\
\hline \multirow[t]{2}{*}{ Route/Leg } & \multicolumn{2}{|c|}{ Maximum } & \multirow{2}{*}{$\begin{array}{c}\text { On-road } \\
\text { ratio/FTP ratio }\end{array}$} & \multicolumn{2}{|c|}{ Average } & \multirow{2}{*}{$\begin{array}{c}\text { On-road } \\
\text { ratio /FTP ratio }\end{array}$} \\
\hline & Ratio & bsNOx & & Ratio & bsNOx & \\
\hline SAB2BM & 0.0110 & 5.187 & 1.10 & 0.0083 & 3.747 & 0.83 \\
\hline BM2SAB & 0.0104 & 5.134 & 1.04 & 0.0083 & 3.813 & 0.83 \\
\hline PA1 & 0.0078 & 3.979 & 0.78 & 0.0059 & 2.933 & 0.59 \\
\hline PA2 & 0.0110 & 5.726 & 1.10 & 0.0079 & 3.573 & 0.79 \\
\hline PA3 & 0.0113 & 5.861 & 1.13 & 0.0118 & 5.009 & 1.17 \\
\hline SAB2SW & 0.0112 & 5.866 & 1.12 & 0.0100 & 4.647 & 1.00 \\
\hline SW2SAB & 0.0097 & 5.916 & 0.97 & 0.0076 & 3.731 & 0.76 \\
\hline
\end{tabular}

Table B-2 Baseline $\mathrm{NO}_{\mathrm{x}} / \mathrm{CO}_{2}$ calculations for a $\mathrm{MY} 1998$ engine

\begin{tabular}{|c|c|c|c|c|c|c|}
\hline \multicolumn{7}{|c|}{ Engine Model Year 1998} \\
\hline \multicolumn{2}{|c|}{ Allowed FTP bsNOx } & 4.0000 & & & & \\
\hline \multicolumn{2}{|c|}{ Allowed FTP bsCO2 } & 475.0000 & & & & \\
\hline \multicolumn{2}{|c|}{ FTP Ratio } & 0.0084 & & & & \\
\hline \multicolumn{2}{|c|}{ Allowed NTE bsNOx } & 5.0000 & & & & \\
\hline \multirow[t]{2}{*}{ Route/Leg } & \multicolumn{2}{|c|}{ Maximum } & \multirow{2}{*}{$\begin{array}{c}\text { On-road } \\
\text { ratio/FTP ratio }\end{array}$} & \multicolumn{2}{|c|}{ Average } & \multirow{2}{*}{$\begin{array}{c}\text { On-road } \\
\text { ratio/FTP ratio }\end{array}$} \\
\hline & Ratio & bsNOx & & Ratio & bsNOx & \\
\hline SAB2BM & 0.0152 & 6.972 & 1.81 & 0.0141 & 6.223 & 1.67 \\
\hline BM2SAB & 0.0152 & 6.773 & 1.81 & 0.0141 & 6.019 & 1.68 \\
\hline SAB2BM & 0.0160 & 7.178 & 1.90 & 0.0144 & 6.276 & 1.71 \\
\hline BM2SAB & 0.0165 & 7.230 & 1.96 & 0.015 & 6.524 & 1.79 \\
\hline PA1 & 0.0087 & 3.993 & 1.03 & 0.0082 & 3.612 & 0.97 \\
\hline PA2 & 0.0170 & 7.861 & 2.02 & 0.0127 & 5.572 & 1.51 \\
\hline PA3 & 0.0213 & 10.21 & 2.53 & 0.0153 & 6.635 & 1.82 \\
\hline PA1 & 0.0151 & 6.857 & 1.80 & 0.0107 & 4.689 & 1.27 \\
\hline PA2 & 0.0148 & 7.058 & 1.75 & 0.0119 & 5.397 & 1.41 \\
\hline PA3 & 0.0167 & 7.582 & 1.98 & 0.0144 & 6.146 & 1.71 \\
\hline SAB2SW & 0.0180 & 8.231 & 2.14 & 0.0137 & 6.108 & 1.62 \\
\hline SW2SAB & 0.0160 & 7.473 & 1.90 & 0.0143 & 6.581 & 1.70 \\
\hline SAB2SW & 0.0143 & 6.571 & 1.70 & 0.0129 & 5.703 & 1.53 \\
\hline SW2SAB & 0.0177 & 8.028 & 2.10 & 0.0136 & 6.025 & 1.61 \\
\hline
\end{tabular}


Table B-3 Baseline $\mathrm{NO}_{\mathrm{x}} / \mathrm{CO}_{2}$ calculations for a $\mathrm{MY} 1998$ engine

\begin{tabular}{|c|c|c|c|c|c|c|}
\hline \multicolumn{7}{|c|}{ Engine Model Year 1998} \\
\hline \multicolumn{2}{|c|}{ Allowed FTP bsNOx } & 4.0000 & & & & \\
\hline \multicolumn{2}{|c|}{ Allowed FTP bsCO2 } & 450.00 & & & & \\
\hline \multicolumn{2}{|c|}{ FTP Ratio } & 0.00890 & & & & \\
\hline \multicolumn{2}{|c|}{ Allowed NTE bsNOx } & 5.0000 & & & & \\
\hline \multirow[t]{2}{*}{ Route/Leg } & \multicolumn{2}{|c|}{ Maximum } & \multirow{2}{*}{$\begin{array}{c}\text { On-road } \\
\text { ratio/FTP ratio }\end{array}$} & \multicolumn{2}{|c|}{ Average } & \multirow{2}{*}{$\begin{array}{c}\text { On-road } \\
\text { ratio/FTP ratio }\end{array}$} \\
\hline & Ratio & bsNOx & & Ratio & bsNOx & \\
\hline SAB2BM & 0.0137 & 6.464 & 1.55 & 0.0132 & 5.565 & 1.48 \\
\hline BM2SAB & 0.0174 & 8.256 & 1.96 & 0.0159 & 6.798 & 1.79 \\
\hline SAB2BM & 0.0125 & 6.064 & 1.40 & 0.0132 & 5.582 & 1.48 \\
\hline BM2SAB & 0.0128 & 6.102 & 1.44 & 0.013 & 5.619 & 1.47 \\
\hline PA1 & 0.0129 & 6.431 & 1.45 & 0.0128 & 5.639 & 1.44 \\
\hline PA2 & 0.0138 & 6.42 & 1.56 & 0.0122 & 5.252 & 1.37 \\
\hline PA3 & 0.0161 & 7.655 & 1.81 & 0.0148 & 6.518 & 1.66 \\
\hline PA1 & 0.0127 & 5.908 & 1.43 & 0.0134 & 5.611 & 1.51 \\
\hline PA2 & 0.0135 & 6.381 & 1.52 & 0.0123 & 5.292 & 1.39 \\
\hline PA3 & 0.0184 & 8.577 & 2.07 & 0.0141 & 5.956 & 1.59 \\
\hline
\end{tabular}

